Supporting Information

\title{
Remote, Diastereoselective Cobalt-Catalyzed Alkene Isomerization-Hydroboration: Access to Stereodefined 1,3-Difunctionalized Indanes
}

Nadia G. Léonard, W. Neil Palmer, Max R. Friedfeld, Máté J. Bezdek and Paul J. Chirik*

Department of Chemistry, Frick Laboratory

Princeton University, Princeton, NJ 08544, USA

pchirik@princeton.edu

Table of Contents

I. General Considerations S3

II. Synthesis and Characterization of Alkenes S6

III. General Procedures for Alkene Hydroboration S30

a. Catalyst Assessment for Hydroboration $\quad$ S31

b. Cobalt Catalyzed Isomerization-Hydroboration S32

c. Cobalt Catalyzed Isomerization-Hydroboration on Gram Scale S32

d. Uncatalyzed Hydroboration with 9-BBN S33

IV. Characterization of Indanyl Boronate Esters $\quad$ S35

V. Synthetic Applications of Indanyl Boronate Esters S56

$\begin{array}{ll}\text { VI. Kinetics } & \text { S63 }\end{array}$

VII. Deuterium Labeling Studies $\quad$ S65

$\begin{array}{ll}\text { VIII. Catalytic Hydroboration of Dialins } & \text { S78 }\end{array}$ 
$\begin{array}{lll}\text { IX. DFT Calculations } & \text { S81 }\end{array}$

$\begin{array}{lll}\text { X. NMR Spectra } & \text { S85 }\end{array}$

$\begin{array}{lrr}\text { XI. References } & \text { S121 }\end{array}$ 


\section{General Considerations}

All air- and moisture-sensitive manipulations were carried out using vacuum line, Schlenk and cannula techniques or in an MBraun inert atmosphere (nitrogen) dry box unless otherwise noted. All glassware was stored in a pre-heated oven prior to use. Hydrogen and deuterium gas were passed through a column containing manganese oxide supported on vermiculite and $4 \AA$ molecular sieves before admission to the high-vacuum line. The solvents used for air- and moisture-sensitive manipulations were dried and deoxygenated using literature procedures. ${ }^{1}$ Deuterated solvents, including $\mathrm{CDCl}_{3}$, were purchased from Cambridge Isotope Laboratories and used without further purification unless otherwise noted. Benzene- $d_{6}$ used for NMR spectroscopy analysis of air-sensitive complexes was distilled from sodium metal under reduced pressure and stored under an $\mathrm{N}_{2}$ atmosphere prior to use. The following compounds [Co]-1, ${ }^{2}$ $[\mathrm{Co}]-2,{ }^{3}[\mathrm{Co}]-3,{ }^{4}$ and $[\mathrm{Co}]-4,{ }^{5}[\mathrm{Co}]-5,{ }^{6}[\mathrm{Co}]-6,{ }^{7}[\mathrm{Co}]-7,{ }^{7}[\mathrm{Co}]-8,{ }^{8}$ and $[\mathrm{Fe}]-1^{9}$ were prepared according to established procedures. Pinacolborane (Aldrich) and 9borabicyclo[3.3.1]nonane (9-BBN) (Aldrich) were used as received without further purification. 1,2-dihydronaphthalene (Aldrich) was dried over $\mathrm{CaH}_{2}$ and distilled prior to use. All liquid substrates were dried over $\mathrm{CaH}_{2}$ and distilled prior to use. All solid substrates were dried under high vacuum and stored under an $\mathrm{N}_{2}$ atmosphere prior to catalytic reactions.

NMR measurements were carried out at $296 \mathrm{~K}$ unless otherwise noted. ${ }^{1} \mathrm{H}$ NMR spectra were recorded on either Bruker AVANCE 300,400 or 500 spectrometers operating at 300.13 $\mathrm{MHz}, 399.80 \mathrm{MHz}$, and $500.46 \mathrm{MHz}$, respectively. ${ }^{13} \mathrm{C}$ NMR spectra were recorded on either Bruker AVANCE 400 or 500 spectrometer operating at $100.54 \mathrm{MHz}$ and $125.85 \mathrm{MHz}$, respectively. ${ }^{11} \mathrm{~B}$ NMR spectra were recorded on a Bruker AVANCE 300 spectrometer operating at $96 \mathrm{MHz}$ and are reported relative to $\mathrm{BF}_{3} \cdot \mathrm{OEt}_{2} \cdot{ }^{19} \mathrm{~F} \mathrm{NMR}$ spectra were collected on a Bruker 400 AVANCE spectrometer operating at $376.15 \mathrm{MHz}$ and were referenced to $\mathrm{CFCl}_{3}$ as an S3 
external standard. All ${ }^{1} \mathrm{H}$ and ${ }^{13} \mathrm{C}$ NMR chemical shifts are reported in ppm relative to $\mathrm{SiMe}_{4}$ using the ${ }^{1} \mathrm{H}$ (chloroform- $d: 7.26$ ppm; benzene- $d_{6}: 7.16$ ppm) and ${ }^{13} \mathrm{C}$ (chloroform- $d: 77.16$ ppm; benzene- $d_{6}$ : $128.06 \mathrm{ppm}$ ) chemical shifts of the solvent as a standard. ${ }^{1} \mathrm{H}$ NMR data for diamagnetic compounds are reported as follows: chemical shift, multiplicity $(s=$ singlet, $d=$ doublet, $\mathrm{t}=$ triplet, $\mathrm{q}=$ quartet, $\mathrm{p}=$ pentet, $\mathrm{br}=$ broad, $\mathrm{m}=$ multiplet, $\mathrm{app}=$ apparent, obsc $=$ obscured), coupling constants $(\mathrm{Hz})$, integration, assignment. ${ }^{1} \mathrm{H}$ NMR data for paramagnetic compounds are reported as follows: chemical shift, integration, peak width at half height $(\mathrm{Hz})$. ${ }^{13} \mathrm{C}$ NMR data for diamagnetic compounds are reported as follows: chemical shift, number of protons attached to carbon (e.g. $\mathrm{CH}_{2}$ ), assignment. Resonances of carbons directly attached to boron were sometimes not observed due to quadrupolar relaxation. ${ }^{10}$

GC analyses were performed using a Shimadzu GC-2010 gas chromatograph equipped with a Shimadzu AOC-20s autosampler and a Shimadzu SHRXI-5MS capillary column (15m x $250 \mu \mathrm{m})$. The instrument was set to an injection volume of $1 \mu \mathrm{L}$, an inlet split ratio of $20: 1$, and inlet and detector temperatures of $250^{\circ} \mathrm{C}$ and $275^{\circ} \mathrm{C}$, respectively. UHP-grade S3 helium was used as carrier gas with a flow rate of $1.82 \mathrm{~mL} / \mathrm{min}$. Typically, the temperature program used for the analyses was as follows: $60^{\circ} \mathrm{C}$, isothermal $1 \mathrm{~min} ; 15^{\circ} \mathrm{C} / \mathrm{min}$ to $250{ }^{\circ} \mathrm{C}$, isothermal $2 \mathrm{~min}$. GC yields were determined by integration of the desired product peaks using cyclooctane as an internal standard.

High-resolution mass spectra were obtained at Princeton University mass spectrometry facilities using an Agilent 6210 TOF LC/MS or Agilent 7200 Q-TOF GC/MS.

Single crystals suitable for X-ray diffraction were coated with polyisobutylene oil in a drybox, transferred to a nylon loop and then quickly transferred to the goniometer head of a Bruker SMART APEX DUO diffractometer equipped with a molybdenum X-ray tube $(\lambda=0.71073 \AA)$ and a Cu X-ray tube $(\lambda=1.54178 \AA)$. Preliminary data revealed the crystal system. The data S4 
collection strategy was optimized for completeness and redundancy using the Bruker COSMO software suite. The space group was identified, and the data were processed using the Bruker SAINT+ program and corrected for absorption using SADABS. The structures were solved using direct methods (SHELXS) completed by subsequent Fourier synthesis and refined by full-matrix least-squares procedures.

All DFT calculations were performed with the ORCA program package in the gas phase. ${ }^{11}$ The geometry optimizations of the complexes and single-point calculations on the optimized geometries were carried out at the B3LYP level of DFT. ${ }^{12}$ The all-electron Gaussian basis sets were those developed by the Ahlrichs group. ${ }^{13}$ Triple- $\zeta$ quality basis sets def2-TZVP with one set of polarization functions on cobalt and nitrogen were used. For the carbon and hydrogen atoms, slightly smaller polarized split-valence def2-SV $(P)$ basis sets were used that were of double- $\zeta$ quality in the valence region and contained a polarizing set of $d$ functions on the nonhydrogen atoms. Auxiliary basis sets to expand the electron density in the resolution-of-theidentity (RIJCOSX) ${ }^{14}$ approach were chosen to match the orbital basis. ${ }^{15}$ Numerical frequencies were calculated at the same level of theory to confirm the optimized geometries (no imaginary frequencies) and to derive thermochemical data. 


\section{Synthesis and Characterization of Alkenes}

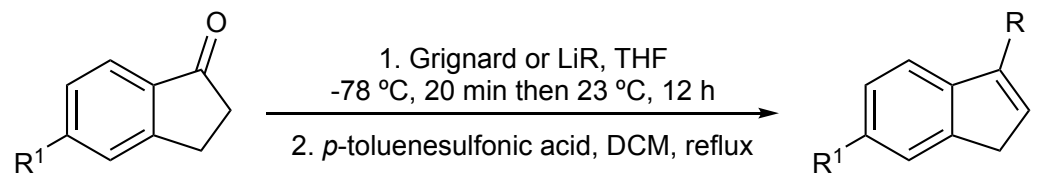

General procedure. On a Schlenk line, a 250-mL oven-dried Schlenk flask was charged with $100 \mathrm{~mL}$ anhydrous tetrahydrofuran, a magnetic stir bar and Grignard reagent or alkyllithium reagent. The reaction vessel was stirred and cooled to $-78^{\circ} \mathrm{C}$ and the corresponding 1 indanone was slowly added. The reaction was allowed to warm to room temperature over 12 hours. The vessel was cooled to $0{ }^{\circ} \mathrm{C}$ and slowly hydrolyzed with aqueous ammonium chloride (10 mL). An additional $100 \mathrm{~mL}$ of water was then added upon complete consumption of the Grignard reagent. The reaction mixture was extracted with diethyl ether $(2 \times 50 \mathrm{~mL})$. The organic layers were combined and washed with $100 \mathrm{~mL}$ of brine and dried with sodium sulfate. Following solvent removal, the crude alcohol was dissolved in $25 \mathrm{~mL}$ dichloromethane and 0.15 g $p$-toluenesulfonic acid $(0.08 \mathrm{mmol})$ was added. The reaction was stirred at room temperature until full consumption of the alcohol was observed by TLC. The reaction mixture was then diluted with $25 \mathrm{~mL}$ dichloromethane and extracted with concentrated aqueous $\mathrm{NaHCO}_{3}$. The organic layer was washed with $50 \mathrm{~mL}$ brine and dried over sodium sulfate. Following filtration, the filtrate was concentrated and the crude alkene product was purified via column chromatography using hexane as the eluent.<smiles>CC1=CCc2ccccc21</smiles>

3-methyl-1H-indene (1a). Prepared according to the general procedure using $100 \mathrm{~mL}$ anhydrous diethyl ether, methylmagnesium chloride $(14.0 \mathrm{~mL}, 3.0 \mathrm{M}$ in THF, 42.0 mmol), and 1-indanone (4.63 g, $35 \mathrm{mmol})$. Yield $2.2 \mathrm{~g}(16.9 \mathrm{mmol}, 48.3 \%) .{ }^{1} \mathrm{H}$ and ${ }^{13} \mathrm{C}$ NMR data agree with values reported. ${ }^{16}$ 
${ }^{1} \mathrm{H}$ NMR $\left(500 \mathrm{MHz}, \mathrm{CDCl}_{3}, 23^{\circ} \mathrm{C}\right): \delta 7.45(\mathrm{~d}, J=7.4 \mathrm{~Hz}$, indenyl $\mathrm{CH}), 7.35(\mathrm{~d}, J=7.1 \mathrm{~Hz}$, indenyl $\mathrm{CH}$ ), 7.31 (apparent t, $J=7.5 \mathrm{~Hz}$, indenyl $\mathrm{CH}$ ), 7.20 (apparent dt, $J=7.3 \mathrm{~Hz}, 1.3 \mathrm{~Hz}, 1 \mathrm{H}$, indenyl $\mathrm{CH}$ ), $6.20\left(\mathrm{~m}, 1 \mathrm{H}, 2\right.$-indenyl $\mathrm{CH}$ ), 3.32 (apparent q, $\mathrm{J}=2.3 \mathrm{~Hz}, 2 \mathrm{H}, 1$-indenyl $\mathrm{CH}_{2}$ ), 2.17 (q, $J=2.1 \mathrm{~Hz}, 3 \mathrm{H}, \mathrm{CH}_{3}$ ).

${ }^{13} \mathrm{C}\left\{{ }^{1} \mathrm{H}\right\}$ NMR $\left(126 \mathrm{MHz}, \mathrm{CDCl}_{3}, 23{ }^{\circ} \mathrm{C}\right.$ ): $\delta 146.3$ (indenyl C), 144.5 (indenyl C), 140.1 (indenyl C), 128.9 (indenyl $\mathrm{CH}$ ), 126.2 (indenyl $\mathrm{CH}$ ), 124.6 (indenyl $\mathrm{CH}$ ), 123.8 (indenyl $\mathrm{CH}$ ), 119.0 (indenyl $\mathrm{CH}$ ), 37.9 (indenyl $\left.\mathrm{CH}_{2}\right) 13.3\left(\mathrm{CH}_{3}\right)$.<smiles>COc1ccc2c(c1)CC=C2C</smiles>

6-methoxy-3-methyl-1 $H$-indene (1b). Prepared according to the general procedure using $100 \mathrm{~mL}$ anhydrous diethyl ether, methylmagnesium chloride $(9.0 \mathrm{~mL}, 3.0 \mathrm{M}$ in THF, $27.0 \mathrm{mmol})$, and 5-methoxy-1-indanone (3.65 g, $22.5 \mathrm{mmol})$. Yield $1.8 \mathrm{~g}(11.2 \mathrm{mmol}$, 49.9\%). ${ }^{1} \mathrm{H}$ and ${ }^{13} \mathrm{C}$ NMR data agree with values reported. ${ }^{17}$

${ }^{1} \mathrm{H}$ NMR $\left(500 \mathrm{MHz}, \mathrm{CDCl}_{3}, 23^{\circ} \mathrm{C}\right): \delta 7.23(\mathrm{~d}, J=8.2 \mathrm{~Hz}, 1 \mathrm{H}$, indenyl $\mathrm{CH}), 7.06(\mathrm{~s}, 1 \mathrm{H}$, indenyl $\mathrm{CH}$ ), 6.88 (dd, $J=8.2,2.4 \mathrm{~Hz}, 1 \mathrm{H}$, indenyl $\mathrm{CH}$ ), 6.07 (d, J=1.6 Hz, 1H, 2-indenyl CH), 3.85 (s, $\left.3 \mathrm{H},-\mathrm{OCH}_{3}\right), 3.30\left(\mathrm{~s}, 2 \mathrm{H}, 1\right.$-indenyl $\left.\mathrm{CH}_{2}\right), 2.15\left(\mathrm{~s}, 3 \mathrm{H}, \mathrm{CH}_{3}\right)$.

${ }^{13} \mathrm{C}\left\{{ }^{1} \mathrm{H}\right\}$ NMR $\left(126 \mathrm{MHz}, \mathrm{CDCl}_{3}, 23{ }^{\circ} \mathrm{C}\right.$ ): $\delta 158.0$ (indenyl C), 146.3 (indenyl C), 139.6 (indenyl C), 126.7 (indenyl $\mathrm{CH}$ ), 124.6 (indenyl C), 119.2 (indenyl $\mathrm{CH}$ ), 111.7 (indenyl $\mathrm{CH}$ ), 110.4 (indenyl $\mathrm{CH}$ ), $55.7\left(-\mathrm{OCH}_{3}\right), 37.7$ (indenyl $\left.\mathrm{CH}_{2}\right), 13.3\left(\mathrm{CH}_{3}\right)$.<smiles>CCC1=CCc2ccccc21</smiles>

3-ethyl-1 $H$-indene (1c). Prepared according to the general procedure using 100 $\mathrm{mL}$ anhydrous diethyl ether, ethylmagnesium chloride (20 mL, 1.0 M in THF, $20.0 \mathrm{mmol})$, and 1indanone (2.64 g, $20.0 \mathrm{mmol})$. Yield $0.897 \mathrm{~g}(6.22 \mathrm{mmol}, 31.1 \%) .{ }^{1} \mathrm{H}$ and ${ }^{13} \mathrm{C}$ NMR data agree with values reported. ${ }^{18}$ 
${ }^{1} \mathrm{H}$ NMR $\left(500 \mathrm{MHz}, \mathrm{CDCl}_{3}, 23^{\circ} \mathrm{C}\right): \delta 7.48(\mathrm{~d}, J=7.3 \mathrm{~Hz}, 1 \mathrm{H}$, indenyl $\mathrm{CH}), 7.38(\mathrm{~d}, \mathrm{~J}=7.5 \mathrm{~Hz}$, $1 \mathrm{H}$, indenyl $\mathrm{CH}$ ), $7.31(\mathrm{t}, \mathrm{J}=7.4 \mathrm{~Hz}, 1 \mathrm{H}$, indenyl $\mathrm{CH}$ ), $7.22(\mathrm{t}, \mathrm{J}=7.4 \mathrm{~Hz}, 1 \mathrm{H}$, indenyl $\mathrm{CH}), 6.22$ (m, $1 \mathrm{H}$, indenyl $\mathrm{CH}$ ), $3.34\left(\mathrm{~s}, 2 \mathrm{H}\right.$, indenyl $\left.\mathrm{CH}_{2}\right), 2.60\left(\mathrm{q}, 2 \mathrm{H},-\mathrm{CH}_{2} \mathrm{CH}_{3}\right), 1.31(\mathrm{t}, \mathrm{J}=7.5 \mathrm{~Hz}, 3 \mathrm{H},-$ $\mathrm{CH}_{2} \mathrm{CH}_{3}$.

${ }^{13} \mathrm{C}\left\{{ }^{1} \mathrm{H}\right\}$ NMR $\left(126 \mathrm{MHz}, \mathrm{CDCl}_{3}, 23{ }^{\circ} \mathrm{C}\right.$ ): $\delta 146.4$ (indenyl C), 145.7 (indenyl C), 144.7 (indenyl C), 126.9 (indenyl $\mathrm{CH}$ ), 126.1 (indenyl C), 124.6 (indenyl $\mathrm{CH}$ ), 123.9 (indenyl $\mathrm{CH}$ ), 119.0 (indenyl $\mathrm{CH}$ ), 37.8 (indenyl $\left.\mathrm{CH}_{2}\right), 20.9\left(\mathrm{CH}_{2}\right), 12.5\left(\mathrm{CH}_{3}\right)$.

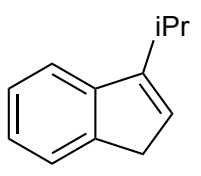

3-isopropyl-1 $H$-indene (1d). Prepared according to the general procedure using $100 \mathrm{~mL}$ anhydrous diethyl ether, isopropylmagnesium chloride $(20.0 \mathrm{~mL}, 1.0 \mathrm{M}$ in THF, 20.0 $\mathrm{mmol})$, and 1-indanone $(1.76 \mathrm{~g}, 13.3 \mathrm{mmol})$. Yield $0.80 \mathrm{~g}(5.0 \mathrm{mmol}, 38 \%) .{ }^{1} \mathrm{H}$ and ${ }^{13} \mathrm{C} \mathrm{NMR}$ data agree with values reported. ${ }^{19}$

${ }^{1} \mathrm{H}$ NMR $\left(500 \mathrm{MHz}, \mathrm{CDCl}_{3}, 23^{\circ} \mathrm{C}\right): \delta 7.46(\mathrm{~d}, J=7.9 \mathrm{~Hz}, 1 \mathrm{H}$, indenyl $\mathrm{CH}), 7.41(\mathrm{~d}, J=8.0 \mathrm{~Hz}$, $1 \mathrm{H}$, indenyl $\mathrm{CH}), 7.29(\mathrm{~m}, 1 \mathrm{H}$, indenyl $\mathrm{CH}), 7.19(\mathrm{~m}, 1 \mathrm{H}$, indenyl $\mathrm{CH}), 6.19(\mathrm{t}, J=7.4 \mathrm{~Hz}, 1 \mathrm{H}$, indenyl $\mathrm{CH}$ ), $3.31\left(\mathrm{~s}, 2 \mathrm{H}\right.$, indenyl $\left.\mathrm{CH}_{2}\right), 2.87\left(\mathrm{~s}, 1 \mathrm{H}, \mathrm{CH}\left(\mathrm{CH}_{3}\right)_{2}\right), 1.28(\mathrm{~d}, J=7.5 \mathrm{~Hz}, 6 \mathrm{H}$, $\left.\mathrm{CH}\left(\mathrm{CH}_{3}\right)_{2}\right)$.

${ }^{13} \mathrm{C}\left\{{ }^{1} \mathrm{H}\right\}$ NMR $\left(126 \mathrm{MHz}, \mathrm{CDCl}_{3}, 23{ }^{\circ} \mathrm{C}\right.$ ): $\delta 151.2$ (indenyl C), 145.1 (indenyl C), 145.0 (indenyl C), 126.0 (indenyl $\mathrm{CH}$ ), 124.5 (indenyl $\mathrm{CH}$ ), 124.0 (indenyl $\mathrm{CH}$ ), 120.0 (indenyl $\mathrm{CH}$ ), 37.7 (indenyl $\mathrm{CH}_{2}$ ), 27.1 (methyne $\mathrm{CH}$ ), $22.0\left(\mathrm{CH}_{3}\right)$.

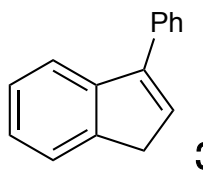

3-phenyl-1H-indene (1e). Prepared according to the general procedure using $100 \mathrm{~mL}$ anhydrous tetrahydrofuran, phenylmagnesium chloride $(17.0 \mathrm{~mL}, 2.0 \mathrm{M}$ in THF, 34 
mmol), and 1-indanone (3.0 g, $22.7 \mathrm{mmol})$. Yield $3.12 \mathrm{~g}(16.23 \mathrm{mmol}, 71 \%) .{ }^{1} \mathrm{H}$ and ${ }^{13} \mathrm{C}$ NMR data agree with values reported. ${ }^{20}$

${ }^{1} \mathrm{H}$ NMR $\left(500 \mathrm{MHz}, \mathrm{CDCl}_{3}, 23{ }^{\circ} \mathrm{C}\right): \delta$ 7.59-7.63 (overlapping $\mathrm{m}, 3 \mathrm{H}$, indenyl $\mathrm{CH}$, phenyl $\mathrm{CH}$ ), $7.55(\mathrm{~d}, J=7.2 \mathrm{~Hz}, 1 \mathrm{H}$, indenyl $\mathrm{CH}), 7.44-7.48(\mathrm{~m}, 2 \mathrm{H}$, phenyl $\mathrm{CH}), 7.36-7.40(\mathrm{~m}, 1 \mathrm{H}$, phenyl $\mathrm{CH}$ ), $7.33(\mathrm{t}, J=7.5 \mathrm{~Hz}$, indenyl $\mathrm{CH}), 7.27(\mathrm{t}, J=7.5 \mathrm{~Hz}, 1 \mathrm{H}, 2 \mathrm{H}$, indenyl $\mathrm{CH}), 6.59(\mathrm{t}, J=2.0$ $\mathrm{Hz}, 1 \mathrm{H}$, indenyl $\mathrm{CH}), 3.52\left(\mathrm{~d}, \mathrm{~J}=1.6 \mathrm{~Hz}, 2 \mathrm{H}\right.$, indenyl $\left.\mathrm{CH}_{2}\right)$.

${ }^{13} \mathrm{C}\left\{{ }^{1} \mathrm{H}\right\}$ NMR $\left(126 \mathrm{MHz}, \mathrm{CDCl}_{3}, 23^{\circ} \mathrm{C}\right): \delta 145.4$ (phenyl or indenyl $C$ ), 145.0 (phenyl or indenyl C), 144.1 (phenyl or indenyl C), 136.4 (phenyl or indenyl C), 131.2 (phenyl or indenyl $C \mathrm{H}$ ), 128.8 (phenyl or indenyl $\mathrm{CH}$ ), 127.9 (phenyl or indenyl $\mathrm{CH}$ ), 127.8 (phenyl or indenyl $\mathrm{CH}$ ), 126.4 (phenyl or indenyl $\mathrm{CH}$ ), 125.1 (phenyl or indenyl $\mathrm{CH}$ ), 124.3 (phenyl or indenyl $\mathrm{CH}$ ), 120.5 (phenyl or indenyl $\mathrm{CH}$ ), 38.4 (1-indenyl $\mathrm{CH}_{2}$ ).

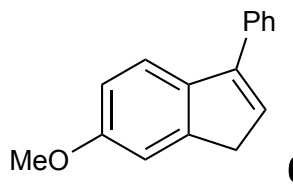

6-methoxy-3-methyl-1H-indene (1f). Prepared according to the general procedure using $100 \mathrm{~mL}$ anhydrous tetrahydrofuran, phenylmagnesium chloride $(13.9 \mathrm{~mL}, 2.0 \mathrm{M}$ in THF, $27.7 \mathrm{mmol})$, and 5-methoxy-1-indanone $(3.00 \mathrm{~g}, 18.5 \mathrm{mmol})$. Yield $2.68 \mathrm{~g}(12.0 \mathrm{mmol}$, $65.2 \%) .{ }^{1} \mathrm{H}$ and ${ }^{13} \mathrm{C}$ NMR data agree with values reported. ${ }^{21}$

${ }^{1} \mathrm{H}$ NMR $\left(500 \mathrm{MHz}, \mathrm{CDCl}_{3}, 23{ }^{\circ} \mathrm{C}\right): \delta 7.61(\mathrm{~m}, 2 \mathrm{H}$, phenyl $\mathrm{CH}), 7.47$ (overlapping $\mathrm{m}, 3 \mathrm{H}$, indenyl $\mathrm{CH}$ or phenyl $\mathrm{CH}), 7.38(\mathrm{~m}, 1 \mathrm{H}$, phenyl $\mathrm{CH}$ or indenyl $\mathrm{CH}), 7.14(\mathrm{~d}, \mathrm{~J}=2.4 \mathrm{~Hz}, 1 \mathrm{H}$, indenyl $\mathrm{CH}$ or phenyl $\mathrm{CH}$ ), $6.89(\mathrm{dd}, J=8.4,2.5 \mathrm{~Hz}$, indenyl $\mathrm{CH}$ or phenyl $\mathrm{CH}), 6.46(\mathrm{t}, J=2.2 \mathrm{~Hz}, 1 \mathrm{H}, 2$ indenyl $\mathrm{CH}$ ), $3.87\left(\mathrm{~s}, 3 \mathrm{H},-\mathrm{OCH}_{2}\right), 3.49\left(\mathrm{~d}, \mathrm{~J}=2.3 \mathrm{~Hz}, 2 \mathrm{H}, 1\right.$-indenyl $\left.\mathrm{CH}_{2}\right)$.

${ }^{13} \mathrm{C}\left\{{ }^{1} \mathrm{H}\right\}$ NMR $\left(126 \mathrm{MHz}, \mathrm{CDCl}_{3}, 23^{\circ} \mathrm{C}\right): \delta 158.2$ (phenyl or indenyl $C$ ), 146.8 (phenyl or indenyl C), 144.9 (phenyl or indenyl $C$ ), 137.2 (phenyl or indenyl $C$ ), 136.5 (phenyl or indenyl $C$ ), 128.8 (2-indenyl $\mathrm{CH}$ ), 128.7 (phenyl $\mathrm{CH}$ ), 127.7 (phenyl $\mathrm{CH}$ ), 127.6 (phenyl or indenyl $\mathrm{CH}$ ), 120.8 
(phenyl or indenyl $\mathrm{CH}$ ), 111.9 (phenyl or indenyl $\mathrm{CH}$ ), 110.7 (phenyl or indenyl $\mathrm{CH}$ ), 55.7 (1indenyl $\left.\mathrm{CH}_{2}\right)$, $38.3\left(-\mathrm{OCH}_{3}\right)$.

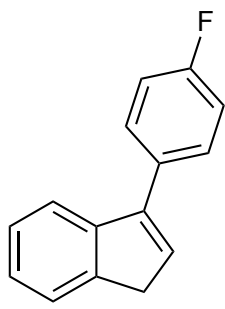

3-(4-fluorophenyl)-1H-indene (1g). Prepared according to the general procedure using $100 \mathrm{~mL}$ anhydrous tetrahydrofuran, 4-fluorophenylmagnesium bromide (20.0 $\mathrm{mL}, 2.0 \mathrm{M}$ in diethyl ether, $40 \mathrm{mmol})$, and 1-indanone $(4.41 \mathrm{~g}, 33.3 \mathrm{mmol})$. Yield $1.88 \mathrm{~g}(8.9$ $\mathrm{mmol}, 27 \%) .{ }^{1} \mathrm{H}$ and ${ }^{13} \mathrm{C}$ NMR data agree with values reported. ${ }^{22}$

${ }^{1} \mathrm{H}$ NMR (500 MHz, $\left.\mathrm{CDCl}_{3}, 23{ }^{\circ} \mathrm{C}\right): \delta$ 7.52-7.59 (overlapping $\mathrm{m}, 4 \mathrm{H}$, aryl $\mathrm{CH}$ indenyl $\mathrm{CH}$ ), 7.33 (t, $J=7.5 \mathrm{~Hz}, 1 \mathrm{H}$, indenyl $\mathrm{CH}), 7.15(\mathrm{~m}, 2 \mathrm{H}$, aryl $\mathrm{CH}), 6.55(\mathrm{t}, J=2.2 \mathrm{~Hz}, 1 \mathrm{H}$, indenyl $\mathrm{CH}), 3.51$ (d, $J=2.2 \mathrm{~Hz}, 2 \mathrm{H}$, indenyl $\mathrm{CH}_{2}$ ).

${ }^{13} \mathrm{C}\left\{{ }^{1} \mathrm{H}\right\} \operatorname{NMR}\left(126 \mathrm{MHz}, \mathrm{CDCl}_{3}, 23^{\circ} \mathrm{C}\right): \delta 162.5(\mathrm{~d}, J=246 \mathrm{~Hz}, p$-aryl CF $), 144.9,144.4$, 143.9, 132.4 (d, $J=3.3 \mathrm{~Hz}$, ipso-aryl C), $131.1,129.5$ (d, $J=7.9 \mathrm{~Hz}, o$-aryl $C H$ ), 126.4, 125.2, $124.4,120.3,115.7\left(\mathrm{~d}, J=21.4 \mathrm{~Hz}, m\right.$-aryl $\mathrm{CH}$ ), 38.4 (1-indenyl $\mathrm{CH}_{2}$ ).

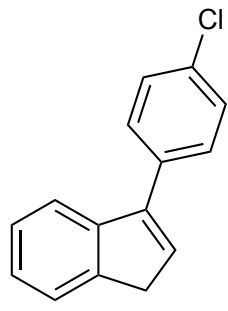

3-(4-chlorophenyl)-1H-indene (1h). Prepared according to the general procedure using $100 \mathrm{~mL}$ anhydrous tetrahydrofuran, 4-chlorophenylmagnesium bromide (25.0 $\mathrm{mL}, 1.0 \mathrm{M}$ in 2-Me-THF, $25 \mathrm{mmol})$, and 1-indanone (3.30 g, $25.0 \mathrm{mmol})$. Yield $2.74 \mathrm{~g}(12.0$ mmol, $48 \%) .{ }^{1} \mathrm{H}$ and ${ }^{13} \mathrm{C}$ NMR data agree with values reported. ${ }^{23}$ 
${ }^{1} \mathrm{H}$ NMR $\left(500 \mathrm{MHz}, \mathrm{CDCl}_{3}, 23^{\circ} \mathrm{C}\right): \delta$ 7.52-7.57 (overlapping $\mathrm{m}, 4 \mathrm{H}$, aryl $\mathrm{CH}$ indenyl $\left.\mathrm{CH}\right), 7.42-$ $7.46(\mathrm{~m}, 2 \mathrm{H}$, aryl $\mathrm{CH}), 7.35(\mathrm{t}, J=7.5 \mathrm{~Hz}, 1 \mathrm{H}$, indenyl $\mathrm{CH}), 7.29(\mathrm{t}, \mathrm{J}=7.3 \mathrm{~Hz}$, indenyl $\mathrm{CH}), 6.59$ (t, $J=2.2 \mathrm{~Hz}, 1 \mathrm{H}$, indenyl $\mathrm{CH}$ ), $3.51\left(\mathrm{~d}, J=2.2 \mathrm{~Hz}, 2 \mathrm{H}\right.$, indenyl $\mathrm{CH}_{2}$ ).

${ }^{13} \mathrm{C}\left\{{ }^{1} \mathrm{H}\right\}$ NMR $\left(126 \mathrm{MHz}, \mathrm{CDCl}_{3}, 23{ }^{\circ} \mathrm{C}\right): 144.9$ (aryl or indenyl C), 144.3 (aryl or indenyl $C$ ), 143.7 (aryl or indenyl C), 134.8 (aryl or indenyl C), 133.5 (aryl or indenyl C), 131.6 (aryl or indenyl $\mathrm{CH}$ ), 129.2 (aryl or indenyl $\mathrm{CH}$ ), 129.0 (aryl or indenyl $\mathrm{CH}$ ), 126.5 (aryl or indenyl $\mathrm{CH}$ ), 125.3 (aryl or indenyl $\mathrm{CH}$ ), 124.4 (aryl or indenyl $\mathrm{CH}$ ), 120.3 (aryl or indenyl $\mathrm{CH}$ ), 38.4 (1-indenyl $\mathrm{CH}_{2}$ ).

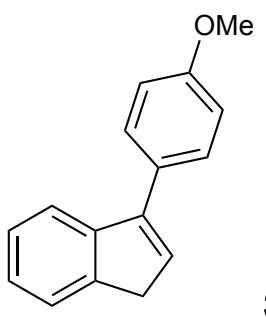

3-(4-methoxyphenyl)-1H-indene (1i). Prepared according to the general procedure using $100 \mathrm{~mL}$ anhydrous tetrahydrofuran, 4-methoxyphenylmagnesium bromide (50.0 $\mathrm{mL}, 0.5 \mathrm{M}$ in THF, $25 \mathrm{mmol})$, and 1-indanone $(3.30 \mathrm{~g}, 25 \mathrm{mmol})$. Yield $2.26 \mathrm{~g}(12.1 \mathrm{mmol}$, 48.2\%). ${ }^{1} \mathrm{H}$ and ${ }^{13} \mathrm{C}$ NMR data agree with values reported. ${ }^{1} \mathrm{H}$ and ${ }^{13} \mathrm{C}$ NMR data agree with values reported. ${ }^{24}$

${ }^{1} \mathrm{H}$ NMR $\left(500 \mathrm{MHz}, \mathrm{CDCl}_{3}, 23{ }^{\circ} \mathrm{C}\right): \delta 7.59(\mathrm{~d}, J=7.6 \mathrm{~Hz}$, indenyl $\mathrm{CH}), 7.53-7.57$ (overlapping m, 3H, aryl $\mathrm{CH}$ indenyl $\mathrm{CH}$ ), $7.33(\mathrm{t}, J=7.5 \mathrm{~Hz}, 1 \mathrm{H}$, indenyl $\mathrm{CH}), 7.26(\mathrm{t}, J=7.6 \mathrm{~Hz}, 1 \mathrm{H}$, indenyl $\mathrm{CH}), 6.52(\mathrm{t}, \mathrm{J}=2.2 \mathrm{~Hz}, 1 \mathrm{H}$, indenyl $\mathrm{CH}), 7.00(\mathrm{~m}, 2 \mathrm{H}$, aryl $\mathrm{CH}), 3.87(\mathrm{~s}, 3 \mathrm{H}, \mathrm{OCH}), 3.50(\mathrm{~d}, J=$ 2.1 $\mathrm{Hz}, 2 \mathrm{H}$, indenyl $\mathrm{CH}_{2}$ ).

${ }^{13} \mathrm{C}\left\{{ }^{1} \mathrm{H}\right\}$ NMR $\left(126 \mathrm{MHz}, \mathrm{CDCl}_{3}, 23^{\circ} \mathrm{C}\right): \delta 159.33$ (aryl or indenyl C), 145.02 (aryl or indenyl $C$ ), 144.80 (aryl or indenyl C), 144.33 (aryl or indenyl C), 130.09 (aryl or indenyl C), 129.02 (aryl or indenyl $\mathrm{CH}$ ), 128.90 (aryl or indenyl $\mathrm{CH}$ ), 126.31 (aryl or indenyl $\mathrm{CH}$ ), 124.95 (aryl or indenyl 
$\mathrm{CH}$ ), 124.29 (aryl or indenyl $\mathrm{CH}$ ), 120.46 (aryl or indenyl $\mathrm{CH}$ ), 114.18 (aryl or indenyl $\mathrm{CH}$ ), 55.54 $\left(-\mathrm{OCH}_{3}\right), 38.28$ (1-indenyl $\left.\mathrm{CH}_{2}\right)$.

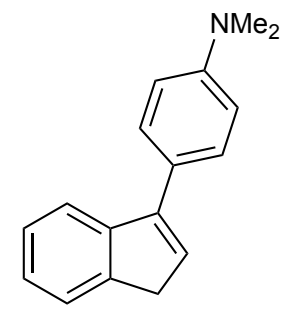

3-(4-(N,N-dimethylaminophenyl)-1 H-indene (1j). Prepared according to the general procedure using $100 \mathrm{~mL}$ anhydrous tetrahydrofuran, 4-(N,N-dimethyl)aniline magnesium bromide (50.0 mL, $0.5 \mathrm{M}$ in THF, $25 \mathrm{mmol})$, and 1-indanone (3.30 g, $25 \mathrm{mmol})$. Yield $3.04 \mathrm{~g}(12.9 \mathrm{mmol}, 51.7 \%) .{ }^{1} \mathrm{H}$ and ${ }^{13} \mathrm{C}$ NMR data agree with values reported. ${ }^{25}$

${ }^{1} \mathrm{H}$ NMR $\left(500 \mathrm{MHz}, \mathrm{CDCl}_{3}, 23^{\circ} \mathrm{C}\right): \delta 7.69(\mathrm{~d}, J=7.6 \mathrm{~Hz}, 1 \mathrm{H}$, indenyl $\mathrm{CH}$ ), 7.55-7.59 (obsc. $\mathrm{m}$, $3 \mathrm{H}$, aryl $\mathrm{CH}$ and indenyl $\mathrm{CH}), 7.37(\mathrm{t}, J=7.4 \mathrm{~Hz}, 1 \mathrm{H}$, indenyl $\mathrm{CH}), 7.29(\mathrm{t}, J=7.1 \mathrm{~Hz}, 1 \mathrm{H}$, indenyl $\mathrm{CH}), 6.87(\mathrm{~m}, 2 \mathrm{H}$, aryl $\mathrm{CH}), 6.52(\mathrm{t}, J=2.2 \mathrm{~Hz}, 1 \mathrm{H}, 2$-indenyl $\mathrm{CH}), 3.53(\mathrm{~d}, J=2.1 \mathrm{~Hz}$, 2H, 1-indenyl $\left.\mathrm{CH}_{2}\right), 3.04\left(\mathrm{~s}, 6 \mathrm{H}, \mathrm{N}\left(\mathrm{CH}_{3}\right)_{2}\right)$.

${ }^{13} \mathrm{C}\left\{{ }^{1} \mathrm{H}\right\}$ NMR $\left(126 \mathrm{MHz}, \mathrm{CDCl}_{3}, 23{ }^{\circ} \mathrm{C}\right.$ ): $\delta 150.3$ (aryl or indenyl $C$ ), 145.1 (aryl or indenyl $C$ ), 145.1 (aryl or indenyl C), 144.4 (aryl or indenyl C), 128.9 (aryl or indenyl C), 128.6 (aryl or indenyl $\mathrm{CH}$ ), 126.2 (aryl or indenyl $\mathrm{CH}$ ), 124.7 (aryl or indenyl $\mathrm{CH}$ ), 124.6 (aryl or indenyl $\mathrm{CH}$ ), 124.2 (aryl or indenyl $\mathrm{CH}$ ), 120.6 (aryl or indenyl $\mathrm{CH}$ ), 112.7 (aryl or indenyl $\mathrm{CH}$ ), 40.8 ($\left.\mathrm{N}\left(\mathrm{CH}_{3}\right)_{2}\right)$, 38.2 (1-indenyl $\mathrm{CH}_{2}$ ).

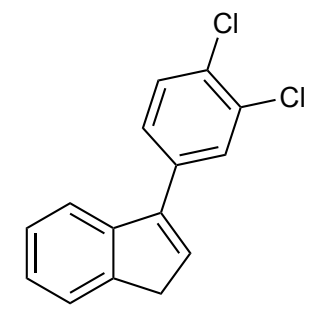

3-(3,4-dichlorophenyl)-1H-indene (1k). Prepared according to the general procedure using $100 \mathrm{~mL}$ anhydrous tetrahydrofuran, 3,4-dichlorophenylmagnesium 
bromide (25.0 mL, 1.0 M in 2-Me-THF, $25 \mathrm{mmol}$ ), and 1-indanone (3.30 g, $25.0 \mathrm{mmol})$. Yield $3.71 \mathrm{~g}(14.2 \mathrm{mmol}, 57 \%)$.

${ }^{1} \mathrm{H}$ NMR $\left(400 \mathrm{MHz}, \mathrm{CDCl}_{3}, 23{ }^{\circ} \mathrm{C}\right): \delta 7.72(\mathrm{~d}, \mathrm{~J}=2.0 \mathrm{~Hz}, 1 \mathrm{H}$, aryl $\mathrm{CH}), 7.56(\mathrm{~m}, 3 \mathrm{H}$, aryl $\mathrm{CH}$, indenyl $\mathrm{CH}$ ), $7.46(\mathrm{dd}, \mathrm{J}=8.3,2.0 \mathrm{~Hz}, 1 \mathrm{H}$, aryl $\mathrm{CH}), 7.37(\mathrm{t}, J=7.4 \mathrm{~Hz}, 1 \mathrm{H}$, indenyl $\mathrm{CH}$ ), 7.34$7.29(\mathrm{~m}, 1 \mathrm{H}$, indenyl $\mathrm{CH}), 6.64(\mathrm{t}, J=2.2 \mathrm{~Hz}, 1 \mathrm{H}$, indenyl $\mathrm{CH}), 3.54(\mathrm{~d}, J=2.3 \mathrm{~Hz}, 2 \mathrm{H}$, indenyl $\mathrm{CH}_{2}$ ).

${ }^{13} \mathrm{C}\left\{{ }^{1} \mathrm{H}\right\}$ NMR $\left(101 \mathrm{MHz}, \mathrm{CDCl}_{3}, 23^{\circ} \mathrm{C}\right): 144.7$ (aryl or indenyl $\left.C\right), 143.2$ (aryl or indenyl $C$ ), 136.3 (aryl or indenyl C), 132.8 (aryl or indenyl C), 132.4 (aryl or indenyl C), 131.6 (aryl or indenyl $\mathrm{CH}$ ), 130.7 (aryl or indenyl $\mathrm{CH}$ ), 129.6 (aryl or indenyl $\mathrm{CH}$ ), 127.1 (aryl or indenyl $\mathrm{CH}$ ), 126.5 (aryl or indenyl $\mathrm{CH}$ ), 125.4 (aryl or indenyl $\mathrm{CH}$ ), 124.4 (aryl or indenyl $\mathrm{CH}$ ), 120.4 (aryl or indenyl $\mathrm{CH}$ ), 38.4 (1-indenyl $\mathrm{CH}_{2}$ ).

HRMS (ESI+) $\mathrm{m} / \mathrm{z}$ calculated for $\mathrm{C}_{15} \mathrm{H}_{10} \mathrm{Cl}_{2}{ }^{+}\left(\mathrm{M}^{+}\right) 260.0159$, found $\mathrm{m} / \mathrm{z} 260.0151$.<smiles>FC(F)(F)C1=CCc2ccccc21</smiles>

3-(trifluoromethyl)-1H-indene (1I). Prepared according to a procedure previously reported by Gassman et al. ${ }^{26}$ Under an argon atmosphere, a $250 \mathrm{~mL}$ Schlenk flask was charged with $70 \mathrm{~mL}$ anhydrous THF, 2,2,2-trifluoroacetophenone (5.3 g, $30.4 \mathrm{mmol}$ ), and a magnetic stir bar. The flask was cooled in an ice bath and vinylmagnesium bromide (1.0 M THF, $38.0 \mathrm{mmol}$ ) was added dropwise by syringe. The reaction was stirred at $0{ }^{\circ} \mathrm{C}$ for $90 \mathrm{~min}$ and quenched with aqueous $\mathrm{NH}_{4} \mathrm{Cl}$. The mixture was extracted with diethyl ether $(3 \times 75 \mathrm{~mL})$ and the combined organic fractions were washed with a saturated solution of $\mathrm{NaHCO}_{3}(75 \mathrm{~mL})$, water (75 $\mathrm{mL})$, and brine $(75 \mathrm{~mL})$. The organics were combined and dried over $\mathrm{MgSO}_{4}$, the solution filtered, and the volatiles removed in vacuo. Vacuum distillation of the residue $\left(85^{\circ} \mathrm{C}, 8 \mathrm{mmHg}\right)$ yielded 2-phenyl-1,1,1-trifluorobut-3-en-2-ol as a colorless liquid $(6.1 \mathrm{~g}, 30.4 \mathrm{mmol}$, quantitative $\mathrm{S} 13$ 
yield) which was used in the next step without further purification. Under an argon atmosphere, a $250 \mathrm{~mL}$ Schlenk flask was charged with $30 \mathrm{~mL}$ methansulfonic acid and 2-phenyl-1,1,1trifluorobut-3-en-2-ol. The reaction was heated in an oil bath to $45^{\circ} \mathrm{C}$ for $10 \mathrm{~min}$ and quenched with $100 \mathrm{~mL}$ ice water. The aqueous solution was then extracted with diethyl ether ( $3 \times 75 \mathrm{~mL})$. The combined organic layers were washed with a saturated solution of $\mathrm{NaHCO}_{3}(50 \mathrm{~mL})$, water $(50 \mathrm{~mL})$, and brine $(50 \mathrm{~mL})$. The organics were dried over $\mathrm{MgSO}_{4}$, filtered, and the volatiles removed in vacuo. Vacuum distillation of the residue $\left(54{ }^{\circ} \mathrm{C}, 1.8 \mathrm{mmHg}\right)$, followed by column chromatography (silica gel, hexanes) yielded the desired product as a clear, colorless liquid (1.17 g, $6.35 \mathrm{mmol}, 20.4 \%$ yield). ${ }^{1} \mathrm{H}$ and ${ }^{13} \mathrm{C}$ NMR data agree with values reported.

${ }^{1} \mathrm{H}$ NMR $\left(500 \mathrm{MHz}, \mathrm{CDCl}_{3}, 23^{\circ} \mathrm{C}\right): \delta 7.54(\mathrm{~m}, 2 \mathrm{H}), 7.33(\mathrm{~m}, 2 \mathrm{H}), 7.01(\mathrm{~s}, 1 \mathrm{H}), 3.54(\mathrm{~s}, 2 \mathrm{H})$.

${ }^{13} \mathrm{C}\left\{{ }^{1} \mathrm{H}\right\}$ NMR $\left(126 \mathrm{MHz}, \mathrm{CDCl}_{3}, 23^{\circ} \mathrm{C}\right): \delta 143.6,139.0,136.2(\mathrm{q}, J=5.0 \mathrm{~Hz}), 125.1(\mathrm{q}, J=$ $34.1 \mathrm{~Hz}), 127.0,126.3,124.3,122.5(\mathrm{q}, J=269.6 \mathrm{~Hz}), 120.7$, 38.3.

${ }^{19} \mathrm{~F}\left\{{ }^{1} \mathrm{H}\right\}$ NMR $\left(96 \mathrm{MHz}, \mathrm{CDCl}_{3}, 23^{\circ} \mathrm{C}\right): \delta-64.10$.

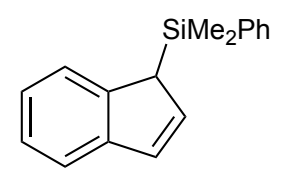

(1H-inden-1-yl)dimethyl(phenyl)silane $(1 \mathrm{~m})$. Prepared according to the previously reported procedure. ${ }^{27}$ In a $\mathrm{N}_{2}$-filled glovebox, a $100 \mathrm{~mL}$ Schlenk flask was charged with indenyllithium $(0.70 \mathrm{~g}, 5.73 \mathrm{mmol})$ as a solid, hexane $(30 \mathrm{~mL})$, and a stir bar. The reaction mixture was sealed with a rubber septum, brought out of the glovebox, and attached to a Schlenk line under Ar. The stirring suspension was then treated dropwise with a solution of dimethylphenylchlorosilane $(0.962 \mathrm{~mL}, 5.73 \mathrm{mmol})$ in hexane $(10 \mathrm{~mL})$, and was stirred at reflux for $5 \mathrm{~h}$. The mixture was filtered and the hexane removed in vacuo. Vacuum distillation of the crude residue yielded the product at $112{ }^{\circ} \mathrm{C} / 0.20 \mathrm{mmHg}$ as a pale yellow liquid. Yield $1.02 \mathrm{~g}$ $(71.0 \%, 4.07 \mathrm{mmol})$. 
${ }^{1} \mathrm{H}$ NMR $\left(500 \mathrm{MHz}, \mathrm{C}_{6} \mathrm{D}_{6}, 23^{\circ} \mathrm{C}\right): \delta 7.30(\mathrm{~d}, J=7.4 \mathrm{~Hz}, 1 \mathrm{H}, 4$-indenyl $\mathrm{CH}), 7.25(\mathrm{~m}, 2 \mathrm{H}, 5-$ or 6indenyl $\mathrm{CH}$ ), 7.02-7.12 (m, $\left.5 \mathrm{H}, \mathrm{Si}\left(\mathrm{CH}_{3}\right)_{2} P h\right), 6.99(\mathrm{~d}, J=8.5 \mathrm{~Hz}, 1 \mathrm{H}, 7$-indenyl $\mathrm{CH}), 6.72(\mathrm{~d}, J=$ 7.0 Hz, $1 \mathrm{H}$, 3-indenyl CH), $6.35\left(\mathrm{~d}, J=7.2 \mathrm{~Hz}, 1 \mathrm{H}\right.$, 2-indenyl $\mathrm{CH}$ ), 3.47 (s, 1H, CHSiMe $\mathrm{Ph}_{2}$, 0.07 (s, $\left.3 \mathrm{H}, \mathrm{Si}\left(\mathrm{CH}_{3}\right)_{2} \mathrm{Ph}\right),-0.12\left(\mathrm{~s}, 3 \mathrm{H}, \mathrm{Si}\left(\mathrm{CH}_{3}\right)_{2} \mathrm{Ph}\right)$.

${ }^{13} \mathrm{C}\left\{{ }^{1} \mathrm{H}\right\}$ NMR $\left(126 \mathrm{MHz}, \mathrm{C}_{6} \mathrm{D}_{6}, 23^{\circ} \mathrm{C}\right.$ ): $\delta 145.4$ (indenyl C), 145.3 (indenyl $C$ ), 137.8 (phenyl C), 135.6 (2-indenyl $\mathrm{CH}$ ), 134.2 (3-, 5-phenyl $\mathrm{CH}$ ), 129.8 (4-phenyl $\mathrm{CH}$ ), 129.7 (3-indenyl $\mathrm{CH}$ ), 128.5 (2-, 6-phenyl $\mathrm{CH}$ ), 125.5 (5-indenyl $\mathrm{CH}$ ), 124.1 (6-indenyl $\mathrm{CH}$ ), 123.3 (7-indenyl $\mathrm{CH}$ ), 121.5 (4-indenyl $\mathrm{CH}$ ), 45.9 (1-indenyl $\mathrm{CH})$, -4.4 $\left(\mathrm{Si}\left(\mathrm{CH}_{3}\right)_{2} \mathrm{Ph}\right),-5.0\left(\mathrm{Si}\left(\mathrm{CH}_{3}\right)_{2} \mathrm{Ph}\right)$.

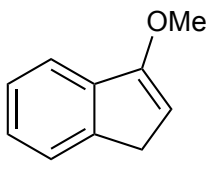

3-methoxy-1H-indene (1n). Prepared according to the previously reported procedure. ${ }^{28}$ A $250 \mathrm{~mL}$ round bottom flask was charged with 1-indanone $(5.00 \mathrm{~g}, 37.8 \mathrm{mmol})$, trimethyl orthoformate $(5.0 \mathrm{~mL}, 45.7 \mathrm{mmol})$, methanol $(10 \mathrm{~mL})$, benzene $(150 \mathrm{~mL})$, and a stir bar. To this stirring solution, a concentrated solution of $\mathrm{HCl}(1 \mathrm{~mL}, 6 \mathrm{M}$ in methanol) was added. After 30 minutes, the reaction was filtered on a fritted glass filter and the volatiles removed in vacuo. The residual oil was purified by vacuum distillation to afford the desired product as colorless oil. Yield $2.92 \mathrm{~g}$ (19.9 mmol, 52.8\%). ${ }^{1} \mathrm{H}$ and ${ }^{13} \mathrm{C}$ NMR data agree with values reported. ${ }^{1} \mathrm{H}$ NMR $\left(500 \mathrm{MHz}, \mathrm{CDCl}_{3}, 23^{\circ} \mathrm{C}\right): \delta 7.43(\mathrm{~m}, 2 \mathrm{H}$, indenyl $\mathrm{CH}), 7.31(\mathrm{t}, J=7.8 \mathrm{~Hz}, 1 \mathrm{H}$, indenyl $\mathrm{CH}), 7.24(\mathrm{~m}, 1 \mathrm{H}$, indenyl $\mathrm{CH}), 5.30(\mathrm{~s}, 1 \mathrm{H}, 2$-indenyl $\mathrm{CH}), 3.88\left(\mathrm{~s}, 3 \mathrm{H},-\mathrm{OCH} \mathrm{H}_{3}\right), 3.32(\mathrm{~d}, \mathrm{~J}=2.1$ $\mathrm{Hz}, 2 \mathrm{H}, 1$-indenyl $\mathrm{CH}_{2}$ ).

${ }^{13} \mathrm{C}\left\{{ }^{1} \mathrm{H}\right\}$ NMR $\left(126 \mathrm{MHz}, \mathrm{CDCl}_{3}, 23{ }^{\circ} \mathrm{C}\right.$ ): $\delta 134.7$ (indenyl C), 127.4 (indenyl C), 126.8 (indenyl C), 126.19 (indenyl $\mathrm{CH}$ ), 125.5 (indenyl $\mathrm{CH}$ ), 124.0 (indenyl $\mathrm{CH}$ ), 118.1 (indenyl $\mathrm{CH}$ ), 97.9 (indenyl $\mathrm{CH}$ ), 56.8 (indenyl $\left.\mathrm{CH}_{2}\right), 34.18\left(-\mathrm{OCH}_{3}\right)$. 

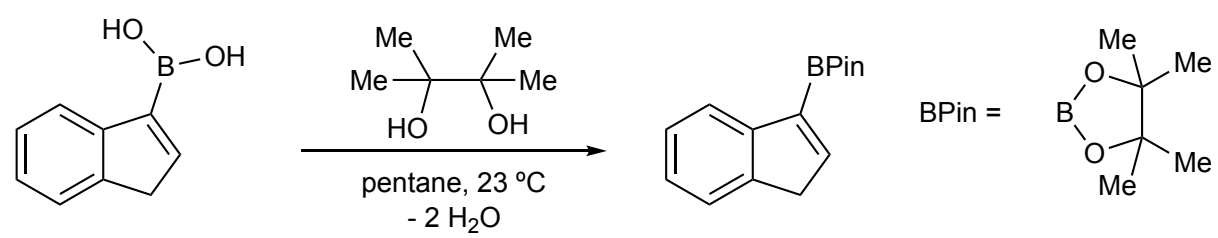

2-(1H-inden-3-yl)-4,4,5,5-tetramethyl-1,3,2-dioxaborolane (10). Prepared according to a modified procedure previously reported by Morken and coworkers. ${ }^{29}$ An oven-dried $100 \mathrm{~mL}$ round bottom flask was charged with (1H-inden-3-yl)boronate acid (3.85 g, $24.0 \mathrm{mmol})$, a magnetic stir bar, and $50 \mathrm{~mL}$ pentane. While stirring the reaction, 2,3-dimethylbutane-2,3-diol (pinacol) (2.99 g, $25.3 \mathrm{mmol}, 1.05$ equiv.) was added and the reaction was allowed to continue to stir at $23{ }^{\circ} \mathrm{C}$ with monitoring by TLC until the reaction was complete. The reaction was then extracted to remove the water layer and the organics dried over $\mathrm{Na}_{2} \mathrm{SO}_{4}$. The solution was then filtered by vacuum filtration on a fritted glass filter and washed with ether $(20 \mathrm{~mL})$. The solvent was removed in vacuo and the resulting residue was purified on silica gel using $\mathrm{CH}_{2} \mathrm{Cl}_{2}$ as the eluent to afford the desired product as a cream colored solid. Yield $4.3 \mathrm{~g}(17.8 \mathrm{mmol}, 73.8 \%)$.

${ }^{1} \mathrm{H}$ NMR $\left(500 \mathrm{MHz}, \mathrm{CDCl}_{3}, 23^{\circ} \mathrm{C}\right): \delta 7.85(\mathrm{~d}, J=7.5 \mathrm{~Hz}, 1 \mathrm{H}$, indenyl $\mathrm{CH}), 7.47(\mathrm{~d}, J=7.2 \mathrm{~Hz}$, $1 \mathrm{H}$, indenyl $\mathrm{CH}$ ), $7.30(\mathrm{t}, J=7.4 \mathrm{~Hz}, 1 \mathrm{H}$, indenyl $\mathrm{CH}$ ), 7.25 (obsc d, 1H, 2-indenyl $\mathrm{CH}$ ), 7.19 (t, $J$ $=7.3 \mathrm{~Hz}, 1 \mathrm{H}$, indenyl $\mathrm{CH}), 3.47\left(\mathrm{~s}, 2 \mathrm{H}\right.$, indenyl $\left.\mathrm{CH}_{2}\right), 1.36\left(\mathrm{~s}, 12 \mathrm{H}, \mathrm{BPin} \mathrm{CH}_{3}\right)$.

${ }^{13} \mathrm{C}\left\{{ }^{1} \mathrm{H}\right\}$ NMR (126 MHz, $\mathrm{CDCl}_{3}, 23{ }^{\circ} \mathrm{C}$ ): $\delta 149.2$ (indenyl $\mathrm{CH}$ ), 146.9 (indenyl C), 143.9 (indenyl $\mathrm{C}$ ), 126.3 (indenyl $\mathrm{CH}$ ), 124.6 (indenyl $\mathrm{CH}$ ), 123.6 (indenyl $\mathrm{CH}$ ), 122.9 (indenyl $\mathrm{CH}$ ), 83.5 (BPin $\mathrm{C}$ ), 40.8 (1-indenyl $\mathrm{CH}_{2}$ ), $25.0\left(\mathrm{BPin} \mathrm{CH}_{3}\right.$ ); the 3-indenyl $\mathrm{C}$ attached to boron was not observed.

${ }^{11}$ B NMR (96 MHz, $\left.\mathrm{CDCl}_{3}\right): \delta 29.3$.

HRMS (ESI+) $m / z$ calculated for $\mathrm{C}_{15} \mathrm{H}_{20} \mathrm{BO}_{2}{ }^{+}\left([\mathrm{M}+\mathrm{H}]^{+}\right) 243.1551$, found $m / z 243.1554$. 

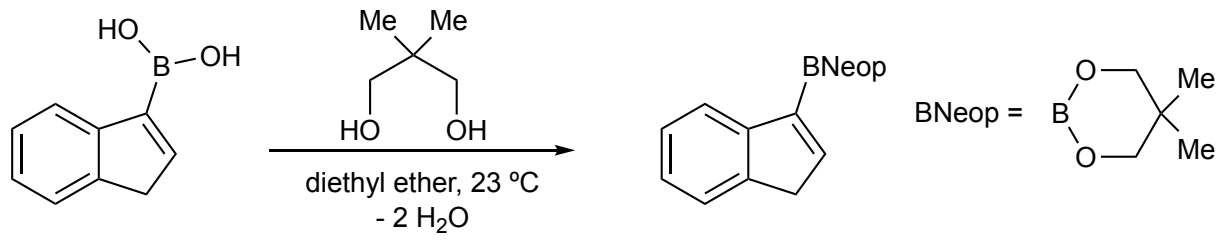

2-(1H-inden-3-yl)-5,5-dimethyl-1,3,2-dioxaborolane (1p). Prepared according to a modified procedure previously reported by Crudden and coworkers. ${ }^{30}$ An oven-dried $50 \mathrm{~mL}$ round bottom flask was charged with (1H-inden-3-yl)boronate acid $(0.300 \mathrm{~g}, 1.875 \mathrm{mmol})$, a magnetic stir bar, $20 \mathrm{~mL}$ diethyl ether, and anhydrous magnesium sulfate $(0.226 \mathrm{~g}, 1.875$ $\mathrm{mmol})$. While stirring the reaction, 2,2-dimethylpropane-2,3-diol $(0.195 \mathrm{~g}, 1.875 \mathrm{mmol})$ was added and the reaction was allowed to continue to stir at $23^{\circ} \mathrm{C}$ with monitoring by TLC until the reaction was complete. The reaction was then directly filtered by vacuum filtration through celite on a fritted-glass filter and washed with diethyl ether $(50 \mathrm{~mL})$. The combined organic layers were concentrated in vacuo to afford the desired product in quantitative yield $(0.428 \mathrm{~g}, 1.876 \mathrm{mmol})$. The product was recrystallized from pentane at $-35^{\circ} \mathrm{C}$ prior to use in catalysis.

${ }^{1} \mathrm{H}$ NMR $\left(500 \mathrm{MHz}, \mathrm{CDCl}_{3}, 23^{\circ} \mathrm{C}\right): \delta 7.87(\mathrm{~d}, J=7.6 \mathrm{~Hz}, 1 \mathrm{H}$, indenyl $\mathrm{CH}), 7.46(\mathrm{~d}, J=7.4 \mathrm{~Hz}$, $1 \mathrm{H}$, indenyl $\mathrm{CH}$ ), 7.27 (t, $J=7.5 \mathrm{~Hz}, 1 \mathrm{H}$, indenyl $\mathrm{CH}$ ), 7.17 (obsc. $\mathrm{m}, 2 \mathrm{H}, 2$-indenyl $\mathrm{CH}$ ), 3.79 (s, 4H, BNeop $\mathrm{CH}_{2}$ ), 3.43 (s, 2H, 1-indenyl $\mathrm{CH}_{2}$ ), 1.04 (s, 6H, BNeop $\mathrm{CH}_{3}$ ).

${ }^{13} \mathrm{C}\left\{{ }^{1} \mathrm{H}\right\}$ NMR $\left(126 \mathrm{MHz}, \mathrm{CDCl}_{3}, 23{ }^{\circ} \mathrm{C}\right.$ ): $\delta 147.5$ (indenyl $\mathrm{CH}$ ), 147.2 (indenyl C), 144.4 (indenyl $\mathrm{C}$ ), 126.2 (indenyl $\mathrm{CH}$ ), 124.3 (indenyl $\mathrm{CH}$ ), 123.5 (indenyl $\mathrm{CH}$ ), 122.9 (indenyl $\mathrm{CH}$ ),

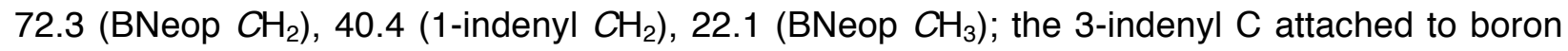
was not observed.

${ }^{11}$ B NMR (96 MHz, $\left.\mathrm{CDCl}_{3}\right): \delta 25.7$.

HRMS (ESI+) $m / z$ calculated for $\mathrm{C}_{14} \mathrm{H}_{17} \mathrm{BO}_{2}{ }^{+}\left(\mathrm{M}^{+}\right)$228.1322, found $\mathrm{m} / \mathrm{z} 228.1320$. 


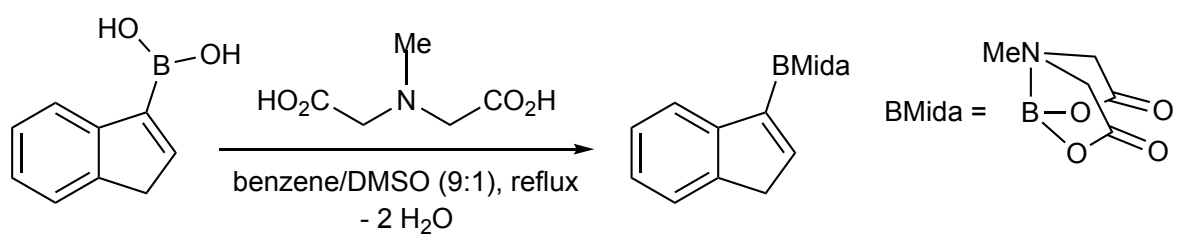

2-(1H-inden-3-yl)- $N$-methyl-1,3,6,2-dioxazaborocane-4,8-dione (1q). Prepared according to a modified procedure previously reported by Burke and coworkers. ${ }^{31} \mathrm{~A}$ oven-dried thick-walled glass vessel was charged with ( $1 H$-inden-3-yl)boronate acid $(0.320 \mathrm{~g}, 2.0 \mathrm{mmol})$, a magnetic stir bar, $3 \mathrm{~mL}$ benzene, $2 \mathrm{~mL}$ DMSO, and $N$-methylimidodiacetic acid $(0.324 \mathrm{~g}, 2.2$ mmol). The reaction vessel was then frozen in liquid nitrogen and the headspace of the reaction evacuated. The reaction vessel was then sealed and brought to room temperature before being placed in an $80{ }^{\circ} \mathrm{C}$ oil bath and allowed to stir for $4 \mathrm{~h}$. The reaction was allowed to cool to room temperature and the volatiles removed in vacuo. To the flask was added water $(10 \mathrm{~mL})$ which caused the crystallization of a colorless solid. The mixture was filtered. The isolated solid was washed with water and dried under vacuum overnight to afford the desired MIDA boronate. Yield $0.464 \mathrm{~g}(1.171 \mathrm{mmol}, 86 \%)$.

${ }^{1} \mathrm{H}$ NMR $\left(500 \mathrm{MHz}, \mathrm{CDCl}_{3}, 23{ }^{\circ} \mathrm{C}\right): \delta 7.51(\mathrm{~d}, J=7.3 \mathrm{~Hz}, 1 \mathrm{H}$, indenyl $\mathrm{CH}), 7.46(\mathrm{~d}, J=7.5 \mathrm{~Hz}$, $1 \mathrm{H}$, indenyl $\mathrm{CH}$ ), $7.28(\mathrm{~d}, J=7.1 \mathrm{~Hz}$, indenyl $\mathrm{CH}), 7.20(\mathrm{t}, 1 \mathrm{H}$, indenyl $\mathrm{CH}), 6.94(\mathrm{t}, J=1.7 \mathrm{~Hz}$, 1H, 2-indenyl $\mathrm{CH}$ ), 3.94-3.47 (m, 4H, Mida $\mathrm{CH}_{2}$ ), $3.47\left(\mathrm{~s}, 2 \mathrm{H}, 1\right.$-indenyl $\left.\mathrm{CH}_{2}\right), 2.76(\mathrm{~s}, 3 \mathrm{H},-$ $\mathrm{NMe})$.

${ }^{13} \mathrm{C}\left\{{ }^{1} \mathrm{H}\right\}$ NMR (126 MHz, $\mathrm{CDCl}_{3}, 23{ }^{\circ} \mathrm{C}$ ): $\delta 167.8\left(\right.$ Mida $-\mathrm{O}_{2} \mathrm{CCH}_{2}$ ), 146.6 (indenyl C), 145.1 (indenyl C), 145.0 (2-indenyl $\mathrm{CH}$ ), 126.7 (indenyl $\mathrm{CH}$ ), 124.9 (indenyl $\mathrm{CH}$ ), 124.1 (indenyl $\mathrm{CH}$ ), 121.9 (indenyl $\mathrm{CH}$ ), 61.8 (Mida $-\mathrm{O}_{2} \mathrm{CCH}_{2}$ ), $47.2(-\mathrm{NMe}), 40.3$ (1-indenyl $\mathrm{CH}_{2}$ ); the 3-indenyl $\mathrm{C}$ attached to boron was not observed.

${ }^{11}$ B NMR $\left(96 \mathrm{MHz}, \mathrm{CDCl}_{3}\right): \delta 10.8$.

HRMS (ESI+) $\mathrm{m} / \mathrm{z}$ calculated for $\mathrm{C}_{14} \mathrm{H}_{14} \mathrm{BNO}_{4}{ }^{+}\left(\mathrm{M}^{+}\right)$271.1016, found $\mathrm{m} / \mathrm{z} 271.1007$. S18 


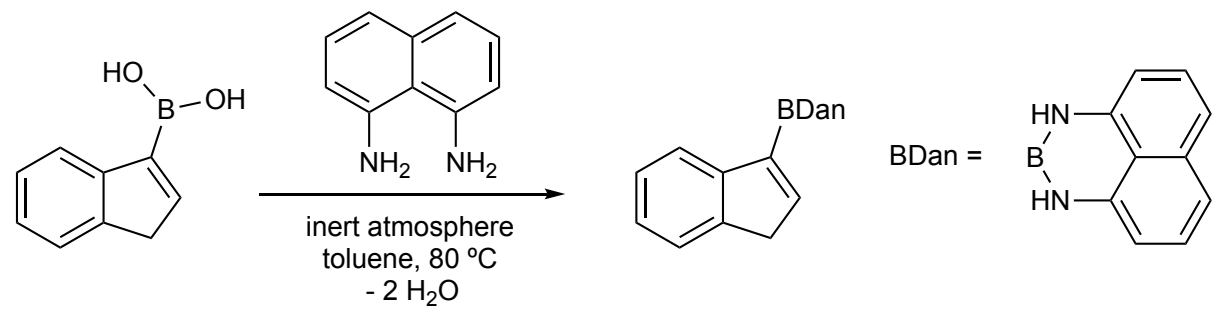

\section{2-(1H-inden-3-yl)-2,3-dihydro-1 $H$-naphtho[1,8-de][1,3,2]diazaborinine}

Prepared according to a modified procedure previously reported by Suginome and coworkers. ${ }^{32}$ In a $\mathrm{N}_{2}$-atmosphere glovebox, an oven-dried thick-walled glass vessel was charged with $(1 \mathrm{H}$ inden-3-yl)boronate acid $(0.500 \mathrm{~g}, 3.13 \mathrm{mmol})$, a magnetic stir bar, $5 \mathrm{~mL}$ toluene, and 1,8diaminonaphthalene $(0.494 \mathrm{~g}, 3.13 \mathrm{mmol})$. The vessel was then sealed, brought out of the glovebox, and placed in an $80^{\circ} \mathrm{C}$ oil bath. The reaction was allowed to stir at this temperature for $24 \mathrm{~h}$, after which the vessel was carefully vented. The crude reaction mixture was dried over magnesium sulfate, filtered and the volatiles removed in vacuo. The residue was dissolved in a minimal amount of chloroform and purified by silica gel column chromatography using hexane:EtOAc $(10: 1)$ as the eluent to yield the desired product as a light peach-colored foam. Yield $0.560 \mathrm{~g}(1.98 \mathrm{mmol}, 63.5 \%)$.

${ }^{1} \mathrm{H}$ NMR $\left(500 \mathrm{MHz}, \mathrm{CDCl}_{3}, 23^{\circ} \mathrm{C}\right): \delta 7.61(\mathrm{~d}, J=7.5 \mathrm{~Hz}, 1 \mathrm{H}, \mathrm{CH}), 7.55(\mathrm{~d}, J=7.4 \mathrm{~Hz}, 1 \mathrm{H}, \mathrm{CH})$, $7.35(\mathrm{t}, J=7.4 \mathrm{~Hz}, 1 \mathrm{H}, \mathrm{CH}), 7.25$ (obsc. m, 1H, CH), $7.14(\mathrm{~m}, 2 \mathrm{H}, \mathrm{CH}), 7.06(\mathrm{~d}, J=8.1 \mathrm{~Hz}, 2 \mathrm{H}$, $\mathrm{CH}$ ), $6.97(\mathrm{~s}, 1 \mathrm{H}, \mathrm{CH}), 6.40(\mathrm{~d}, J=7.3 \mathrm{~Hz}, 2 \mathrm{H}, \mathrm{CH}), 6.01$ (broad s, 2H, NH), $3.50(\mathrm{~s}, 2 \mathrm{H}, 1-$ indenyl $\mathrm{CH}_{2}$ ).

${ }^{13} \mathrm{C}\left\{{ }^{1} \mathrm{H}\right\}$ NMR $\left(126 \mathrm{MHz}, \mathrm{CDCl}_{3}, 23^{\circ} \mathrm{C}\right.$ ): $\delta 146.8$ (indenyl $C$ or Dan $C$ ), 144.6 (indenyl $C$ or Dan C), 142.9 (indenyl $\mathrm{CH}$ ), 141.1 (indenyl $C$ or Dan $C$ ), 136.5 (indenyl $C$ or Dan $C$ ), 127.7 (Dan $\mathrm{CH}$ ), 126.5 (indenyl $\mathrm{CH}$ ), 124.9 (indenyl $\mathrm{CH}$ ), 124.2 (indenyl $\mathrm{CH}$ ), 121.4 (indenyl $\mathrm{CH}$ ), 118.0 
(Dan $\mathrm{CH}$ ), 106.1 (Dan $\mathrm{CH}$ ), 40.6 (1-indenyl $\mathrm{CH}_{2}$ ); the 3-indenyl $\mathrm{C}$ attached to boron was not observed.

${ }^{11}$ B NMR (96 MHz, $\left.\mathrm{CDCl}_{3}\right): \delta 28.6$.

HRMS (ESI+) $m / z$ calculated for $\mathrm{C}_{19} \mathrm{H}_{15} \mathrm{BN}_{2}{ }^{+}\left(\mathrm{M}^{+}\right)$282.1328, found $m / z$ 282.1325.

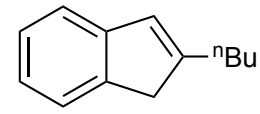

2-butyl-1 $H$-indene (1s). Prepared according to the previously reported procedure. ${ }^{33}$ To a stirred solution of 2-butyl-2,3-dihydro-1 $H$-inden-1-one $(1.169 \mathrm{~g}, 6.21 \mathrm{mmol})$ in methanol $\left(50 \mathrm{~mL}\right.$ ) was added $\mathrm{NaBH}_{4}$ (3 equiv., $18.6 \mathrm{mmol}$ ) portionwise. The reaction mixture was followed by TLC and after complete consumption of the starting material (approx. $2 \mathrm{~h}$ ), was quenched with saturated $\mathrm{NaHCO}_{3}$. The aqueous layer was extracted with diethyl ether, dried over magnesium sulfate, filtered and the solvent was removed in vacuo. The crude alcohol was dissolved in toluene $(15 \mathrm{~mL})$ and a catalytic amount of $p$-toluenesulfonic acid was added. The reaction mixture was refluxed for $3 \mathrm{~h}$, then neutralized by slow addition of saturated sodium bicarbonate and extracted with diethyl ether. The combined organic layers were washed with brine, dried over magnesium sulfate, filtered, and the solvent was removed in vacuo. The product was purified by column chromatography using hexanes as the eluent to give the desired alkene. Yield $0.65 \mathrm{~g}$ (3.8 mmol, 61\%). ${ }^{1} \mathrm{H}$ and ${ }^{13} \mathrm{C}$ NMR data agree with values reported.

${ }^{1} \mathrm{H}$ NMR $\left(500 \mathrm{MHz}, \mathrm{CDCl}_{3}, 23{ }^{\circ} \mathrm{C}\right): \delta$ 7.04-7.40 (m, 4H, indenyl $\left.\mathrm{CH}\right), 6.48(\mathrm{~s}, 1 \mathrm{H}$, indenyl $\mathrm{CH})$, 3.28 (s, 2H, 1-indenyl $\mathrm{CH}_{2}$ ), 2.45 (t, $\left.J=7.0 \mathrm{~Hz}, 2 \mathrm{H}, \mathrm{CH}_{2}\left(\mathrm{CH}_{2}\right)_{2} \mathrm{CH}_{3}\right), 1.32-1.64(\mathrm{~m}, 2 \mathrm{H}$, $\left.\mathrm{CH}_{2} \mathrm{CH}_{2} \mathrm{CH}_{2} \mathrm{CH}_{3}\right), 1.28-1.44\left(\mathrm{~m}, 2 \mathrm{H}, \mathrm{CH}_{2} \mathrm{CH}_{2} \mathrm{CH}_{2} \mathrm{CH}_{3}\right), 0.93\left(\mathrm{t}, J=7.0 \mathrm{~Hz}, 3 \mathrm{H}, \mathrm{CH}_{3}\right)$.

${ }^{13} \mathrm{C}\left\{{ }^{1} \mathrm{H}\right\}$ NMR (126 MHz, $\left.\mathrm{CDCl}_{3}, 23{ }^{\circ} \mathrm{C}\right): \delta 150.9$ (2-indenyl C), 145.7 (indenyl C), 143.1 (indenyl $\mathrm{C}$ ), 126.2 (3-indenyl $\mathrm{CH}$ ), 126.1 (indenyl $\mathrm{CH}$ ), 123.4 (indenyl $\mathrm{CH}$ ), 123.3 (indenyl $\mathrm{CH}$ ), 119.8 (indenyl $\mathrm{CH}$ ), 41.0 (indenyl $\left.\mathrm{CH}_{2}\right), 31.2\left(\mathrm{CH}_{2} \mathrm{CH}_{2} \mathrm{CH}_{2} \mathrm{CH}_{3}\right), 30.9\left(\mathrm{CH}_{2} \mathrm{CH}_{2} \mathrm{CH}_{2} \mathrm{CH}_{3}\right), 22.5$ $\left(\mathrm{CH}_{2} \mathrm{CH}_{2} \mathrm{CH}_{2} \mathrm{CH}_{3}\right), 13.9\left(\mathrm{CH}_{3}\right)$. 


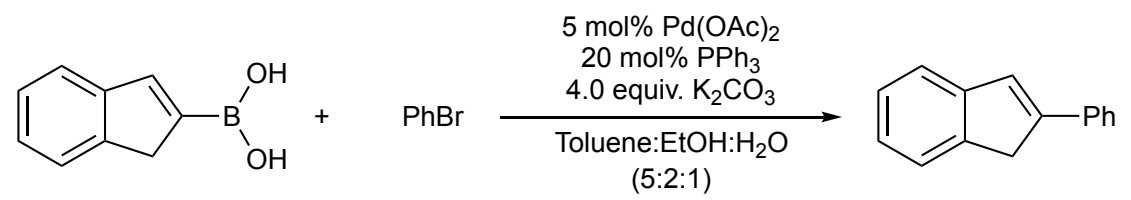

2-phenyl-1 $H$-indene (1t). Prepared according to the previously reported procedure. ${ }^{34}$ In an $\mathrm{N}_{2}$-atmosphere glovebox, a $40 \mathrm{~mL}$ scintillation vial was charged with (1H-inden-2-yl)boronic acid $(0.320 \mathrm{~g}, 2.0 \mathrm{mmol}), \mathrm{Pd}(\mathrm{OAc})_{2}(0.022 \mathrm{~g}, 0.100 \mathrm{mmol}), \mathrm{PPh}_{3}(0.105 \mathrm{~g}, 0.400 \mathrm{mmol}), \mathrm{K}_{2} \mathrm{CO}_{3}$ (1.106 $\mathrm{g}, 8.0 \mathrm{mmol})$, and a stir bar. The vial was sealed with a screw cap fitted with a Teflon septum and brought out of the glovebox. A 5:2:1 ratio of toluene, $\mathrm{EtOH}$, and $\mathrm{H}_{2} \mathrm{O}(24 \mathrm{~mL}$ total volume) was then added via syringe. Phenylbromide $(0.314 \mathrm{~g}, 2.0 \mathrm{mmol})$ was then added to the stirring solution via syringe. The mixture was placed in a heat block set to $80^{\circ} \mathrm{C}$ and allowed to stir at this temperature for $24 \mathrm{~h}$. The reaction was then cooled to room temperature and diluted and extracted with $\mathrm{Et}_{2} \mathrm{O}$. The organic layers were combined and dried over $\mathrm{MgSO}_{4}$, filtered, and the volatiles removed in vacuo. The crude residue was purified by flash column chromatography using hexanes as the eluent to afford the desired product as a beige solid. Yield $0.30 \mathrm{~g}$ (1.6 mmol, $79 \%) .{ }^{1} \mathrm{H}$ and ${ }^{13} \mathrm{C}$ NMR data agree with values reported.

${ }^{1} \mathrm{H}$ NMR $\left(500 \mathrm{MHz}, \mathrm{CDCl}_{3}, 23{ }^{\circ} \mathrm{C}\right): \delta$ 7.64-7.62 (m, 2H, indenyl $\left.\mathrm{CH}\right), 7.47(\mathrm{~d}, J=7.4 \mathrm{~Hz}, 1 \mathrm{H}$, indenyl $\mathrm{CH}), 7.41-7.36(\mathrm{~m}, 3 \mathrm{H}), 7.29-7.23(\mathrm{~m}, 3 \mathrm{H}), 7.18(\mathrm{td}, J=7.4,1.2 \mathrm{~Hz}, 1 \mathrm{H}), 3.79(\mathrm{~s}, 2 \mathrm{H}, 1-$ indenyl $\mathrm{CH}_{2}$ ).

${ }^{13} \mathrm{C}\left\{{ }^{1} \mathrm{H}\right\} \mathrm{NMR}\left(126 \mathrm{MHz}, \mathrm{CDCl}_{3}, 23{ }^{\circ} \mathrm{C}\right.$ ): $\delta 146.3$ (indenyl $C$ ), 145.3 (indenyl $C$ ), 143.1 (indenyl C), 135.9 (phenyl $C$ ), 128.6 (phenyl $\mathrm{CH}$ ), 127.5 (indenyl $\mathrm{CH}$ ), 126.6 (indenyl $\mathrm{CH}$ ), 126.5 (indenyl $\mathrm{CH}$ ), 125.6 (phenyl $\mathrm{CH}$ ), 124.7 (phenyl $\mathrm{CH}$ ), 123.6 (indenyl $\mathrm{CH}$ ), 120.9 (indenyl $\mathrm{CH}$ ), $38.9\left(\mathrm{CH}_{2}\right.$ ).<smiles>OB(O)C1=Cc2ccccc2C1</smiles>

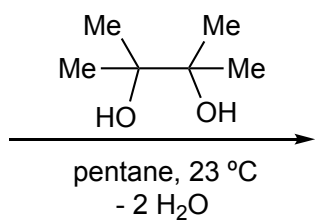

BPin =<smiles>CC1(C)OBOC1(C)C</smiles> 
2-(1H-inden-2-yl)- 4,4,5,5-tetramethyl-1,3,2-dioxaborolane (1u). Prepared according to the procedure for 10 using $50 \mathrm{~mL}$ pentane, $(1 H$-inden-2-yl)boronic acid $(1.44 \mathrm{~g}, 9.0 \mathrm{mmol})$, and 2,3-dimethylbutane-2,3-diol (pinacol) $(1.1 \mathrm{~g}, 9.0 \mathrm{mmol})$. Yield $2.1 \mathrm{~g}(8.7 \mathrm{mmol}, 97 \%) .{ }^{1} \mathrm{H}$ and ${ }^{13} \mathrm{C}$ NMR data agree with values reported. ${ }^{35}$

${ }^{1} \mathrm{H}$ NMR $\left(500 \mathrm{MHz}, \mathrm{CDCl}_{3}, 23^{\circ} \mathrm{C}\right): \delta 7.58(\mathrm{~s}, 1 \mathrm{H}), 7.50(\mathrm{~d}, J=7.0 \mathrm{~Hz}, 1 \mathrm{H}), 7.46(\mathrm{~d}, J=7.0$ $\mathrm{Hz}, 1 \mathrm{H})$, 7.30-7.21 (m, 2H), $3.54(\mathrm{~s}, 2 \mathrm{H}), 1.33(\mathrm{~s}, 12 \mathrm{H})$.

${ }^{13} \mathrm{C}\left\{{ }^{1} \mathrm{H}\right\}$ NMR (126 MHz, $\left.\mathrm{CDCl}_{3}, 23{ }^{\circ} \mathrm{C}\right): \delta 147.1,145.8,145.0,126.4,126.0,124.0,122.0$, 83.6, 41.6, 25.0.

${ }^{11} \mathrm{~B}$ NMR $\left(96 \mathrm{MHz}, \mathrm{CDCl}_{3}\right): \delta 28.3$.

$$
\mathrm{PPh}_{3} \mathrm{Mel}
$$
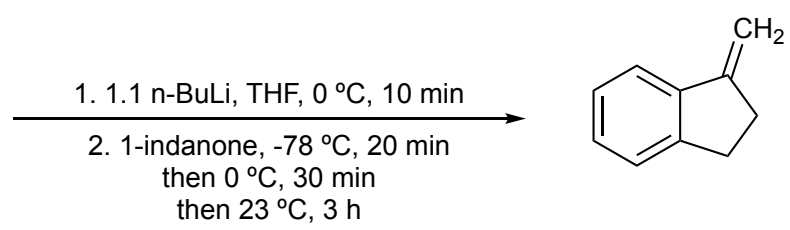
then $23^{\circ} \mathrm{C}, 3 \mathrm{~h}$

1-exo-methylene-indane (1 aa). Prepared according to a previously reported procedure ${ }^{36} \mathrm{~A}$ $250 \mathrm{~mL}$ Schlenk flask was charged with a magnetic stir bar, $100 \mathrm{~mL}$ THF, and $10.37 \mathrm{~g}$ methyltriphenylphosphonium iodide $(25.7 \mathrm{mmol})$. The suspension was cooled to $0{ }^{\circ} \mathrm{C}$ and a solution of butyllithium (13.38 mL, $2.4 \mathrm{M}$ in hexane, $32.1 \mathrm{mmol}$ ) was added by cannula transfer, resulting in a red solution. The reaction was allowed to stir at this temperature for $10 \mathrm{~min}$, following which time it was cooled to $-78{ }^{\circ} \mathrm{C}$ and $3.05 \mathrm{~g} 1$-indanone was added. The reaction was allowed to stir for $20 \mathrm{~min}$ at this temperature and then warmed to $0{ }^{\circ} \mathrm{C}$ and stirred for an additional $30 \mathrm{~min}$ before finally warming to $23^{\circ} \mathrm{C}$. The reaction progress was monitored by TLC, and after $3 \mathrm{~h}$, the reaction was quenched with water $(50 \mathrm{~mL})$. The mixture was then transferred to a separatory funnel and the organic layer separated. The aqueous layer was extracted with diethyl ether $(3 \times 50 \mathrm{~mL})$ and the organics combined and dried over $\mathrm{MgSO}_{4}$. Removal of the volatiles in vacuo and purification of the crude residue by silica column chromatography using S22 
hexane as the eluent yielded the desired product as a clear oil. Yield $1.61 \mathrm{~g}(12.37 \mathrm{mmol}$, 53.5\%). ${ }^{1} \mathrm{H}$ and ${ }^{13} \mathrm{C}$ NMR data agree with values reported.

${ }^{1} \mathrm{H}$ NMR $\left(500 \mathrm{MHz}, \mathrm{CDCl}_{3}, 23{ }^{\circ} \mathrm{C}\right): \delta$ 7.52-7.58 (m, 1H, 4-indenyl $\left.\mathrm{CH}\right), 7.30-7.33(\mathrm{~m}, 1 \mathrm{H}, 6-$ or 7-indanyl $\mathrm{CH}$ ), 7.23-7.29 (overlapping $\mathrm{m}, 2 \mathrm{H}, 5$-indanyl and 6- or 7-indanyl $\mathrm{CH}$ ), 5.51 (t, $\mathrm{J}=2.6$ $\mathrm{Hz}, 1 \mathrm{H}$, alkenyl $\mathrm{CH}$ ), $5.09(\mathrm{t}, J=2.3 \mathrm{~Hz}, 1 \mathrm{H}$, alkenyl $\mathrm{CH}$ ), $3.04(\mathrm{dd}, J=8.3,5.7 \mathrm{~Hz}, 2 \mathrm{H}, 3$-indanyl $\mathrm{CH}_{2}$ ), 2.86 (tt, $\mathrm{J}=7.0,2.3 \mathrm{~Hz}, 2 \mathrm{H}, 2$-indanyl $\mathrm{CH}_{2}$ ).

${ }^{13} \mathrm{C}\left\{{ }^{1} \mathrm{H}\right\}$ NMR $\left(126 \mathrm{MHz}, \mathrm{CDCl}_{3}, 23^{\circ} \mathrm{C}\right): \delta 150.8$ (7a-indanyl C), 146.9 (3a-indanyl C), 141.3 (1indanyl $C$ ), 128.4 (5-indanyl $\mathrm{CH}$ ), 126.6 (7-indanyl $\mathrm{CH}$ ), 125.6 (6-indanyl $\mathrm{CH}$ ), 120.8 (4-indanyl $\mathrm{CH}$ ), 102.6 (methylene $\mathrm{CH}_{2}$ ), 31.4 (2-indanyl $\mathrm{CH}_{2}$ ), 30.3 (3-indanyl $\mathrm{CH}_{2}$ ).

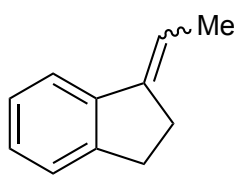

1-exo-ethylidene-indane (1ca). Prepared according to the procedure above with $8.22 \mathrm{~g}$ ethyltriphenylphosphonium bromide $(22.1 \mathrm{mmol}), 11.7 \mathrm{~mL}$ butyllithium $(2.4 \mathrm{M}$ in hexane, $28.2 \mathrm{mmol})$, and $2.66 \mathrm{~g} \mathrm{1-indanone} \mathrm{(20.1} \mathrm{mmol).} \mathrm{Yield} 1.83 \mathrm{~g}(12.7 \mathrm{mmol}, 63 \%)$ as a 2:1 mixture of the $E: Z$ isomers. ${ }^{1} \mathrm{H}$ and ${ }^{13} \mathrm{C}$ NMR data agree with values reported. ${ }^{37}$

${ }^{1} \mathrm{H}$ NMR $\left(500 \mathrm{MHz}, \mathrm{CDCl}_{3}, 23{ }^{\circ} \mathrm{C}\right): \delta 7.63(\mathrm{~d}, J=7.5 \mathrm{Mz}, 1 \mathrm{H}$, Z-isomer indanyl $\mathrm{CH}), 7.43(\mathrm{~m}$, $1 \mathrm{H}, E$-isomer indanyl $\mathrm{CH}$ ), 7.15-7.29 (overlapping $\mathrm{m}, 3 \mathrm{H}$, indanyl $\mathrm{CH}), 6.01(\mathrm{~m}, 1 \mathrm{H}, \mathrm{E}$-isomer alkenyl $\mathrm{CH}), 5.67(\mathrm{~m}, 1 \mathrm{H}, \mathrm{Z}$-isomer alkenyl $\mathrm{CH}), 3.01\left(\mathrm{~m}, 2 \mathrm{H}, \mathrm{E}\right.$-isomer 3-indanyl $\left.\mathrm{CH}_{2}\right), 2.93(\mathrm{~m}$, 2H, Z-isomer 3-indanyl $\mathrm{CH}_{2}$ ), 2.73 (overlapping $\mathrm{m}, 2 \mathrm{H}, 2$-indanyl $\mathrm{CH}_{2}$ ), 2.01 (d, $\mathrm{J}=7.25 \mathrm{~Hz}, 3 \mathrm{H}$, Z-isomer $\left.\mathrm{CH}_{3}\right), 1.77\left(\mathrm{~d}, \mathrm{~J}=6.9 \mathrm{~Hz}, 3 \mathrm{H}, \mathrm{E}\right.$-isomer $\mathrm{CH}_{3}$ ).

${ }^{13} \mathrm{C}\left\{{ }^{1} \mathrm{H}\right\}$ NMR $\left(126 \mathrm{MHz}, \mathrm{CDCl}_{3}, 23{ }^{\circ} \mathrm{C}\right): \delta 145.9,143.1,141.9,127.3,126.5,126.3,125.4$, $124.9,119.8,116.8,113.7,33.7,30.5,30.1,27.8,14.8,14.6$.

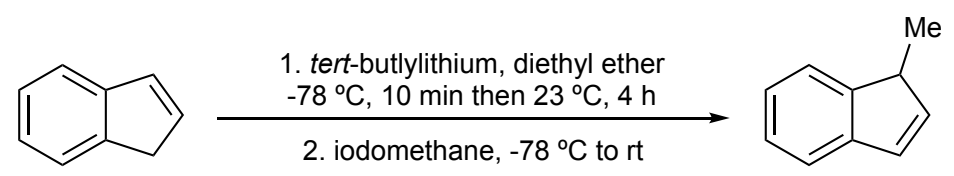


1-methyl-1H-indene (1ab). A $100 \mathrm{~mL}$ oven-dried Schlenk flask was charged with $30 \mathrm{~mL}$ anhydrous diethyl ether, $4.49 \mathrm{~g}(38.6 \mathrm{mmol})$ of freshly distilled indene and cooled to $-78^{\circ} \mathrm{C}$ on a Schlenk line. To the stirred reaction flask was added $25 \mathrm{~mL}$ (42.5 mmol, $1.7 \mathrm{M}$ in hexane) of tert-butyllithium via cannula transfer. The reaction flask was allowed to warm to room temperature and was stirred for $4 \mathrm{~h}$. Following cooling to $-78{ }^{\circ} \mathrm{C}, 5.48 \mathrm{~g}(38.6 \mathrm{mmol}, 4.51 \mathrm{~mL})$ of iodomethane was added by syringe, and upon completion, the reaction flask was allowed to warm to room temperature. The reaction mixture was slowly hydrolyzed with $50 \mathrm{~mL}$ water and extracted with hexane $(2 \times 50 \mathrm{~mL})$. The organic layers were combined, washed with $30 \mathrm{~mL}$ brine and dried over sodium sulfate. Upon filtration and solvent removal, the crude alkene was purified via fractional distillation (the fraction containing the product distilled under dynamic vacuum with the boiling point of $24{ }^{\circ} \mathrm{C}$ at $\left.10 \mathrm{mmHg}\right)$, affording $2.57 \mathrm{~g}(19.7 \mathrm{mmol}, 51 \%$ yield $)$ of the desired alkene as a pale yellow oil. ${ }^{1} \mathrm{H}$ and ${ }^{13} \mathrm{C}$ NMR data agree with values reported. ${ }^{38}$

${ }^{1} \mathrm{H}$ NMR $\left(500 \mathrm{MHz}, \mathrm{CDCl}_{3}, 23{ }^{\circ} \mathrm{C}\right): \delta 7.43(\mathrm{~d}, J=7.3 \mathrm{~Hz}, 4$ - or 7-indenyl $\mathrm{CH}), 7.36(\mathrm{~d}, J=7.4$ $\mathrm{Hz}$, 4- or 7-indenyl $\mathrm{CH}$ ), 7.26 (obsc. t, 5- or 6-indenyl $\mathrm{CH}$ ), 7.21 (t, $J=7.2 \mathrm{~Hz}, 5$ - or 6-indenyl CH), $6.79(\mathrm{~d}, J=5.4 \mathrm{~Hz}$, 3-indenyl $\mathrm{CH}), 6.49(\mathrm{~d}, J=5.2 \mathrm{~Hz}, 1 \mathrm{H}, 2$-indenyl $\mathrm{CH}$ ), $3.50(\mathrm{q}, J=7.5$ $\mathrm{Hz}, 1 \mathrm{H}, 1$-indenyl $\mathrm{CH}), 1.33\left(\mathrm{~d}, \mathrm{~J}=7.8 \mathrm{~Hz}, 3 \mathrm{H}, \mathrm{CH}_{3}\right)$.

${ }^{13} \mathrm{C}\left\{{ }^{1} \mathrm{H}\right\} \operatorname{NMR}\left(126 \mathrm{MHz}, \mathrm{CDCl}_{3}, 23{ }^{\circ} \mathrm{C}\right): \delta 149.4,144.1,141.6,130.3,126.6,124.9,122.8$, $121.2,45.3,16.2$<smiles>CC1=CCCc2ccccc21</smiles>

1-methyl-3,4-dihydronaphthalene (7a). On a Schlenk line, a $500 \mathrm{~mL}$ ovendried Schlenk flask was charged with $200 \mathrm{~mL}$ anhydrous diethyl ether, a magnetic stir bar and $25 \mathrm{~mL}$ of methylmagnesium iodide (3 $\mathrm{M}$ in diethyl ether, $75 \mathrm{mmol}$ ). The reaction vessel was stirred and cooled to $-78{ }^{\circ} \mathrm{C}$ and $9.14 \mathrm{~g}(62.5 \mathrm{mmol})$ 1-tetralone was slowly added. The reaction 
was allowed to warm to room temperature over $12 \mathrm{~h}$. The vessel was cooled to $0{ }^{\circ} \mathrm{C}$ and slowly hydrolyzed with aqueous ammonium chloride $(10 \mathrm{~mL})$. An additional $100 \mathrm{~mL}$ water was then added upon complete consumption of the Grignard reagent. The reaction mixture was extracted with diethyl ether $(2 \times 75 \mathrm{~mL})$. The organic layers were combined and washed with $100 \mathrm{~mL}$ of brine and dried with sodium sulfate. Following solvent removal, the crude alcohol was dissolved in $30 \mathrm{~mL}$ dichloromethane and $0.30 \mathrm{~g}$ p-toluenesulfonic acid $(0.16 \mathrm{mmol})$ was added. The reaction was stirred at room temperature until full consumption of the alcohol was observed by TLC (4 h). The reaction mixture was then diluted with $50 \mathrm{~mL}$ dichloromethane and extracted with conc. aqueous $\mathrm{NaHCO}_{3}$. The organic layer was washed with $50 \mathrm{~mL}$ brine and dried over sodium sulfate. Following filtration, the filtrate was concentrated and the crude product was purified via vacuum distillation to afford $7.315 \mathrm{~g}(50.7 \mathrm{mmol}, 81 \%$ yield $)$ of the desired alkene as a clear oil. ${ }^{1} \mathrm{H}$ and ${ }^{13} \mathrm{C}$ NMR data agree with values reported. ${ }^{39}$

${ }^{1} \mathrm{H}$ NMR (500 MHz, $\mathrm{CDCl}_{3}, 23{ }^{\circ} \mathrm{C}$ ): $\delta$ 7.23-29 (overlapping $\mathrm{m}, 2 \mathrm{H}$, aryl $\mathrm{CH}$ ), 7.15-7.21 (overlapping $\mathrm{m}, 2 \mathrm{H}$, aryl $\mathrm{CH}$ ), $5.90\left(\mathrm{~m}, 1 \mathrm{H}\right.$, alkenyl $\mathrm{CH}$ ), $2.81\left(\mathrm{t}, J=8.1 \mathrm{~Hz}, 2 \mathrm{H}\right.$, benzylic $\mathrm{CH}_{2}$ ), $2.30\left(\mathrm{~m}, 2 \mathrm{H}\right.$, allylic $\mathrm{CH}_{2}$ ), 2.10 (apparent q, $\mathrm{J}=1.7 \mathrm{~Hz}, 3 \mathrm{H}$, alkenyl $\mathrm{CH}_{3}$ ).

${ }^{13} \mathrm{C}\left\{{ }^{1} \mathrm{H}\right\}$ NMR $\left(126 \mathrm{MHz}, \mathrm{CDCl}_{3}, 23{ }^{\circ} \mathrm{C}\right): \delta 146.5,136.0,132.4,127.5,126.9,126.5,125.6$ $123.0,28.6,23.4,19.5$.<smiles>C1=C(c2ccccc2)c2ccccc2CC1</smiles>

1-methyl-3,4-dihydronaphthalene (7b). On a Schlenk line, a $250 \mathrm{~mL}$ ovendried Schlenk flask was charged with $100 \mathrm{~mL}$ anhydrous THF, a magnetic stir bar and phenylmagnesium chloride $(17.0 \mathrm{~mL}, 2.0 \mathrm{M}$ in THF, $34 \mathrm{mmol})$. The reaction vessel was stirred and cooled to $-78{ }^{\circ} \mathrm{C}$ and $2.77 \mathrm{~mL}(20.8 \mathrm{mmol})$ 1-tetralone was slowly added. The reaction was allowed to warm to room temperature over $6 \mathrm{~h}$. The vessel was cooled to $0{ }^{\circ} \mathrm{C}$ and slowly 
hydrolyzed with aqueous ammonium chloride $(10 \mathrm{~mL})$. An additional $100 \mathrm{~mL}$ water was then added upon complete consumption of the Grignard reagent. The reaction mixture was extracted with ethyl acetate $(2 \times 75 \mathrm{~mL})$. The organic layers were combined and washed with $100 \mathrm{~mL}$ of brine and dried with sodium sulfate. Following solvent removal, the crude alcohol was dissolved in $30 \mathrm{~mL}$ toluene and $0.30 \mathrm{~g} p$-toluenesulfonic acid $(0.16 \mathrm{mmol})$ was added. The reaction was refluxed for $6 \mathrm{~h}$, then brought to room temperature. The reaction mixture was then diluted with $50 \mathrm{~mL}$ dichloromethane and extracted with conc. aqueous $\mathrm{NaHCO}_{3}$. The organic layer was washed with $50 \mathrm{~mL}$ brine and dried over sodium sulfate. Following filtration, the filtrate was concentrated and the crude product was purified via column chromatography using hexanes as the eluent to afford $2.22 \mathrm{~g}(10.8 \mathrm{mmol}, 51.7 \%$ yield $)$ of the desired alkene as a pale yellow oil. ${ }^{1} \mathrm{H}$ and ${ }^{13} \mathrm{C}$ NMR data agree with values reported. ${ }^{40}$

${ }^{1} \mathrm{H}$ NMR $\left(500 \mathrm{MHz}, \mathrm{CDCl}_{3}, 23^{\circ} \mathrm{C}\right): \delta 7.31-41$ (overlapping o-, $m$-, $p$-phenyl $\mathrm{CH}$ ), 7.21 (d, $J=7.3$ $\mathrm{Hz}, 1 \mathrm{H}$, aryl $\mathrm{CH}), 7.17(\mathrm{t}, J=7.3 \mathrm{~Hz}$, aryl $\mathrm{CH}), 7.12(\mathrm{t}, J=7.5 \mathrm{~Hz}, 1 \mathrm{H}$, aryl $\mathrm{CH}), 7.01(\mathrm{~d}, J=7.6$ $\mathrm{Hz}$, aryl $\mathrm{CH}$ ), $6.10(\mathrm{t}, \mathrm{J}=4.6 \mathrm{~Hz}, 1 \mathrm{H}$, alkenyl $\mathrm{CH}), 2.87\left(\mathrm{t}, \mathrm{J}=8.0 \mathrm{~Hz}, 2 \mathrm{H}\right.$, benzylic $\left.\mathrm{CH}_{2}\right), 2.42(\mathrm{~m}$, $2 \mathrm{H}$, allylic $\mathrm{CH}_{2}$ ).

${ }^{13} \mathrm{C}\left\{{ }^{1} \mathrm{H}\right\}$ NMR $\left(126 \mathrm{MHz}, \mathrm{CDCl}_{3}, 23{ }^{\circ} \mathrm{C}\right): \delta 141.0,140.1,137.0,135.5,128.9,128.4,127.9$, $127.8,127.3,127.2,126.4,125.6,28.5,23.7$.<smiles>C1=CC(Cc2ccccc2)c2ccccc2C1</smiles>

4-benzyl-1,2-dihydronaphthalene (7c). On a Schlenk line, a $250 \mathrm{~mL}$ ovendried Schlenk flask was charged with $100 \mathrm{~mL}$ anhydrous THF, a magnetic stir bar and benzylmagnesium chloride $(20.0 \mathrm{~mL}, 1.4 \mathrm{M}$ in THF, $28.0 \mathrm{mmol})$. The reaction vessel was stirred and cooled to $-78{ }^{\circ} \mathrm{C}$ and $2.33 \mathrm{~mL}(17.5 \mathrm{mmol}) 1$-tetralone was slowly added. The reaction was allowed to warm to room temperature over $6 \mathrm{~h}$. The vessel was cooled to $0^{\circ} \mathrm{C}$ and slowly S26 
hydrolyzed with aqueous ammonium chloride $(10 \mathrm{~mL})$. An additional $100 \mathrm{~mL}$ water was then added upon complete consumption of the Grignard reagent. The reaction mixture was extracted with ethyl acetate $(2 \times 75 \mathrm{~mL})$. The organic layers were combined and washed with $100 \mathrm{~mL}$ of brine and dried with sodium sulfate. Following solvent removal, the crude alcohol was dissolved in $30 \mathrm{~mL}$ toluene and $0.30 \mathrm{~g}$ p-toluenesulfonic acid $(0.16 \mathrm{mmol})$ was added. The reaction was refluxed for $6 \mathrm{~h}$, then brought to room temperature. The reaction mixture was then diluted with $50 \mathrm{~mL}$ dichloromethane and extracted with conc. aqueous $\mathrm{NaHCO}_{3}$. The organic layer was washed with $50 \mathrm{~mL}$ brine and dried over sodium sulfate. Following filtration, the filtrate was concentrated and the crude product was purified via column chromatography using hexanes as the eluent to afford $2.17 \mathrm{~g}(9.85 \mathrm{mmol}, 56.3 \%$ yield $)$ of the desired alkene as a clear oil. ${ }^{1} \mathrm{H}$ and ${ }^{13} \mathrm{C}$ NMR data agree with values reported. ${ }^{41}$

${ }^{1} \mathrm{H}$ NMR $\left(500 \mathrm{MHz}, \mathrm{CDCl}_{3}, 23^{\circ} \mathrm{C}\right): \delta 7.40(\mathrm{~d}, J=4.4 \mathrm{~Hz}, 1 \mathrm{H}$, aryl $\mathrm{CH}), 7.29(\mathrm{~m}, 4 \mathrm{H}$, aryl $\mathrm{CH})$, $7.23(\mathrm{~m}, 2 \mathrm{H}$, aryl $\mathrm{CH}), 7.15(\mathrm{~m}, 2 \mathrm{H}$, aryl $\mathrm{CH}), 5.83(\mathrm{t}, J=4.6 \mathrm{~Hz}, 1 \mathrm{H}$, alkenyl $\mathrm{CH}), 3.82(\mathrm{~s}, 2 \mathrm{H}$, benzylic $\left.\mathrm{CH}_{2}\right), 2.81\left(\mathrm{t}, \mathrm{J}=8.0 \mathrm{~Hz}, 2 \mathrm{H}, \mathrm{CH}_{2}\right), 2.34\left(\mathrm{~m}, 2 \mathrm{H}\right.$, allylic $\left.\mathrm{CH}_{2}\right)$.

${ }^{13} \mathrm{C}\left\{{ }^{1} \mathrm{H}\right\}$ NMR $\left(126 \mathrm{MHz}, \mathrm{CDCl}_{3}, 23{ }^{\circ} \mathrm{C}\right): \delta 140.2,136.8,135.4,135.0,128.9,128.5,127.7$, $127.6,126.8,126.4,126.1,123.3,39.24,28.5,23.4$.<smiles>C=C1CCCc2ccccc21</smiles>

1-exo-methylene-tetralin (7d). A $250 \mathrm{~mL}$ oven-dried schlenk flask was charged with a magnetic stir bar, $100 \mathrm{~mL}$ tetrahydrofuran and assembled on a schlenk line under inert atmosphere. To the flask was added $20.0 \mathrm{~g}(56 \mathrm{mmol})$ methyltriphenylphosphonium bromide. The flask was cooled to $0{ }^{\circ} \mathrm{C}$ and $6.28 \mathrm{~g}(56 \mathrm{mmol})$ of potassium tert-butoxide was added, resulting in the formation of an orange suspension. Following stirring for 10 minutes, $7.44 \mathrm{~g}$ (50.9 mmol) of 1-tetralone was added followed by warming to room temperature and stirring for 
3 hours. Following hydrolysis with slow addition of $10 \mathrm{~mL}$ of concentrated aqueous ammonium chloride and dilution with $100 \mathrm{~mL}$ water, the reaction was extracted with diethyl ether $(2 \times 50$ $\mathrm{mL}$ ). The organic layers were combined and washed with $50 \mathrm{~mL}$ brine and dried over magnesium sulfate. Following solvent evaporation, the crude product was purified via column chromatography using hexane as the eluent. Vacuum distillation (the fraction containing the product came over with the boiling point of $34{ }^{\circ} \mathrm{C}$ at approximately 50 mtorr using the schlenk line vacuum) afforded $2.73 \mathrm{~g}(26 \mathrm{mmol}, 51 \%$ yield $)$ of 1 -exo-methylene-tetralin as a clear oil. ${ }^{1} \mathrm{H}$ and ${ }^{13} \mathrm{C}$ NMR spectra are consistent with previously reported data. ${ }^{42}$

${ }^{1} \mathrm{H}$ NMR $\left(500 \mathrm{MHz}, \mathrm{CDCl}_{3}, 23^{\circ} \mathrm{C}\right): \delta$ 7.64-7.67 (m, 1H, 8-tetralinyl $\mathrm{CH}$ ), 7.13-7.20 (overlapping m, 2H, 6-tetralinyl $\mathrm{CH}$, 7-tetralinyl $\mathrm{CH}), 7.09-7.12(\mathrm{~m}, 1 \mathrm{H}, 5$-tetralinyl $\mathrm{CH}), 5.48$ (apparent q, $J=$ $1.2 \mathrm{~Hz}, 1 \mathrm{H}$, alkenyl $\mathrm{CH}$ ), 4.96 (apparent q, $J=1.4 \mathrm{~Hz}, 1 \mathrm{H}$, alkenyl $\mathrm{CH}$ ), $2.86(\mathrm{t}, J=6.3 \mathrm{~Hz}, 2 \mathrm{H}$, 4- tetralinyl $\mathrm{CH}_{2}$ ), 2.55 (tt, $J=6.2,1.1 \mathrm{~Hz}, 1 \mathrm{H}$, 2-tetralinyl $\left.\mathrm{CH}_{2}\right), 1.89\left(\mathrm{~m}, 2 \mathrm{H}, 3\right.$-tetralinyl $\left.\mathrm{CH}_{2}\right)$.

${ }^{13} \mathrm{C}\left\{{ }^{1} \mathrm{H}\right\}$ NMR $\left(126 \mathrm{MHz}, \mathrm{CDCl}_{3}, 23{ }^{\circ} \mathrm{C}\right): \delta 143.65$ (1-tetralinyl $\left.\mathrm{C}\right), 137.52$ (4a- or 8a tetralinyl C), 134.90 (4a- or 8a tetralinyl $C$ ), 129.41 (5-tetralinyl $\mathrm{CH}$ ), 127.79 (6- or 7 tetralinyl $\mathrm{CH}$ ), 126.08 (6- or 7 tetralinyl $\mathrm{CH}$ ), 124.40 (8-tetralinyl $\mathrm{CH}$ ), 108.07 (alkenyl $\mathrm{CH}_{2}$ ), 33.45 (2-tetralinyl $\mathrm{CH}_{2}$ ), 30.67 (4-tetralinyl $\mathrm{CH}_{2}$ ), 24.01 (3-tetralinyl $\mathrm{CH}_{2}$ ).

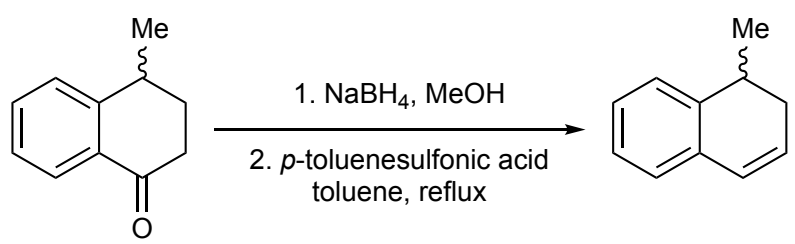

1-methyl-1,2-dihydronaphthalene (7e). Prepared according to the previously reported procedure. ${ }^{43}$ To a stirred solution of 4 -methyl- $\alpha$-tetralone $(3.44 \mathrm{~g}, 21.5 \mathrm{mmol})$ in methanol $(50$ $\mathrm{mL})$ was added $\mathrm{NaBH}_{4}(2.44 \mathrm{~g}, 64.5 \mathrm{mmol})$ portionwise. The reaction mixture was followed by TLC and after complete consumption of the starting material (approx. $2 \mathrm{~h}$ ), was quenched with saturated $\mathrm{NaHCO}_{3}$. The aqueous layer was extracted with diethyl ether, dried over magnesium $\mathrm{S} 28$ 
sulfate, filtered and the solvent was removed in vacuo. The crude alcohol was dissolved in toluene $(15 \mathrm{~mL})$ and $0.030 \mathrm{~g}$-toluenesulfonic acid $(0.17 \mathrm{mmol})$ was added. The reaction mixture was refluxed for $3 \mathrm{~h}$, then neutralized by slow addition of saturated sodium bicarbonate and extracted with diethyl ether. The combined organic layers were washed with brine, dried over magnesium sulfate, filtered, and the solvent was removed in vacuo. The product was purified by column chromatography using hexanes as the eluent to give the desired alkene as a clear oil $(2.1 \mathrm{~g}, 13 \mathrm{mmol}, 60 \%$ yield).

${ }^{1} \mathrm{H}$ NMR (400 MHz, $\left.\mathrm{CDCl}_{3}, 23^{\circ} \mathrm{C}\right): \delta 7.17(\mathrm{~m}, 3 \mathrm{H}), 7.03(\mathrm{~m}, 1 \mathrm{H}), 6.45(\mathrm{~d}, J=9.6 \mathrm{~Hz}, 1 \mathrm{H}), 5.96$ (dt, $J=9.3,4.4 \mathrm{~Hz}, 1 \mathrm{H}), 2.95$ (sext., $J=7.0 \mathrm{~Hz}, 1 \mathrm{H}), 2.49(\mathrm{~m}, 1 \mathrm{H}), 2.14(\mathrm{~m}, 1 \mathrm{H}), 1.26(\mathrm{~d}, J=7.0$ $\mathrm{Hz}, 3 \mathrm{H})$.

${ }^{13} \mathrm{C}\left\{{ }^{1} \mathrm{H}\right\}$ NMR $\left(101 \mathrm{MHz}, \mathrm{CDCl}_{3}, 23{ }^{\circ} \mathrm{C}\right): \delta 140.6,140.5,127.6,127.4,127.3,126.4,126.3$, $126.2,31.8,31.4,20.3$ 


\section{General Procedures for Alkene Hydroboration}

\section{a. Catalyst Assessment for Hydroboration}

In a typical experiment, a $20 \mathrm{~mL}$ scintillation vial (with a magnetic stir bar) was charged in the glovebox with the specified precatalyst $(5 \mathrm{~mol} \%)$. Toluene $(1 \mathrm{~mL})$ solvent was then added via syringe, followed by indene $(0.1 \mathrm{mmol})$ and cyclooctane $(0.1 \mathrm{mmol})$ as internal standard. HBPin $(0.105 \mathrm{mmol})$ was then added to the reaction mixture. The vial was capped and allowed to stir in the glove box for the specified amount of time, after which the vial was brought out of the glove box and the reaction quenched by exposure to air. An aliquot of the crude reaction mixture was then analyzed by gas chromatography and a yield of boronate ester determined against cyclooctane standard. 
Table S1. Catalyst activity for various metal alkyl complexes for hydroboration of substituted indene.

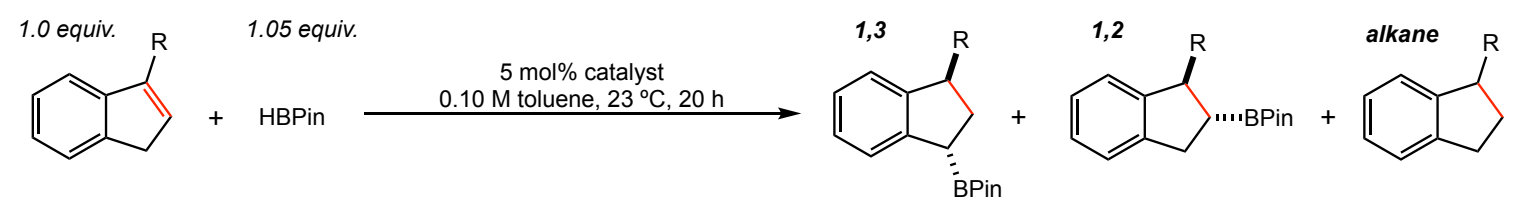

\begin{tabular}{|c|c|c|c|c|c|}
\hline Entry & Catalyst & $R$ & $1,3(\%)^{a}$ & $1,2(\%)^{a}$ & alkane (\%) \\
\hline 1 & [Co]-1 & $\mathrm{Me}$ & $>98(>20: 1 d r)^{a}$ & $<5$ & $<5$ \\
\hline 2 & {$[\mathrm{Co}]-1$} & $\mathrm{Ph}$ & $>98(>20: 1 d r)^{a}$ & $<5$ & $<5$ \\
\hline 3 & [Co]-2 & $\mathrm{Me}$ & $88(>20: 1 d r)^{\mathrm{a}}$ & $<5$ & 12 \\
\hline 4 & {$[\mathrm{Co}]-2$} & $\mathrm{Ph}$ & $61(>20: 1 d r)^{a}$ & $<5$ & $<5$ \\
\hline 5 & {$[\mathrm{Co}]-3$} & $\mathrm{Me}$ & $65(>20: 1 d r)^{a}$ & $<5$ & 35 \\
\hline 6 & {$[\mathrm{Co}]-3$} & $\mathrm{Ph}$ & $63(>20: 1 d r)^{a}$ & $<5$ & 20 \\
\hline 7 & {$[\mathrm{Co}]-4$} & $\mathrm{Me}$ & $35(>20: 1 d r)^{\mathrm{a}}$ & $<5$ & 54 \\
\hline $8^{b}$ & [Co]-4 & $\mathrm{Ph}$ & $40(>20: 1 d r)^{a}$ & $<5$ & 56 \\
\hline $9^{b}$ & [Co]-5 & $\mathrm{Me}$ & $<5$ & $<5$ & $<5$ \\
\hline $10^{b}$ & {$[\mathrm{Co}]-5$} & $\mathrm{Ph}$ & $<5$ & $<5$ & 33 \\
\hline $11^{b}$ & {$[\mathrm{Co}]-6$} & $\mathrm{Me}$ & $<5$ & $<5$ & $<5$ \\
\hline $12^{\mathrm{b}}$ & [Co]-6 & $\mathrm{Ph}$ & $<5$ & $<5$ & $<5$ \\
\hline $13^{b}$ & {$[\mathrm{Co}]-7$} & $\mathrm{Ph}$ & $<5$ & $<5$ & $<5$ \\
\hline $14^{\mathrm{b}}$ & {$[\mathrm{Co}]-8$} & $\mathrm{Ph}$ & $<5$ & $<5$ & 11 \\
\hline $15^{\mathrm{b}}$ & {$[\mathrm{Fe}]-1$} & $\mathrm{Ph}$ & $<5$ & $<5$ & $<5$ \\
\hline
\end{tabular}

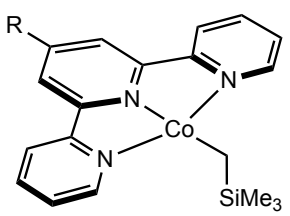

$\mathrm{R}=\mathrm{H}$ [Co]-1 $\mathrm{R}=4-\mathrm{NMe}_{2} \mathrm{Ph} \quad[\mathrm{Co}]-2$

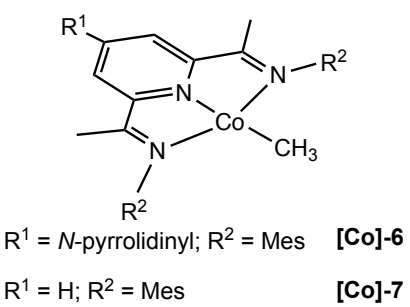

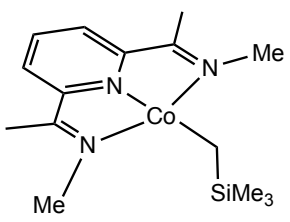

[Co]-3<smiles>N[C@@H]([PH2+])[PH2]c1ccccc1</smiles>

[Co]-4<smiles>CCCc1cccc(N2C(C)=C(C)N(C)C2OC(C)C)c1</smiles>

[Co]-5
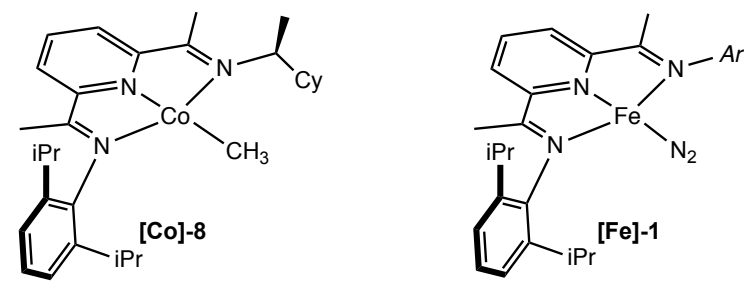

Unless otherwise noted, reactions conducted with $0.10 \mathrm{mmol}$ of indene, $0.105 \mathrm{mmol}$ HBPin, $0.005 \mathrm{mmol}$ precatalyst in $1.0 \mathrm{~mL}$ toluene at $23^{\circ} \mathrm{C}$ for $20 \mathrm{~h}$. ${ }^{a}$ Yield and $d r$ was determined from the calibrated relative integrals of product and cyclooctane signals measured by gas chromotographic analysis of the unpurified mixture. ${ }^{\text {DN }}$ o rectivity was observed after $48 \mathrm{~h}$. 


\section{b. General Procedure for Cobalt Catalyzed Isomerization-Hydroboration}

In a typical experiment, a scintillation vial was charged in the glove box with the specified amount of [Co]-1 and a magnetic stir bar. The specified solvent was then added via syringe followed by the indene substrate. HBPin was then added to the reaction mixture. The vial was capped and the mixture was allowed to stir at the desired temperature for the specified reaction time. Unless otherwise noted, the mixture was then quenched by exposure to air. The mixture was concentrated then purified by flash column chromatography unless otherwise noted. The

resulting solid or oil was then analyzed by ${ }^{1} \mathrm{H}$ NMR, ${ }^{13} \mathrm{C}$ NMR, ${ }^{11} \mathrm{~B}$ NMR, and HRMS to verify the identity and purity of the product. Unless otherwise noted, products are stable in air as solids for weeks, with slight decomposition of the boronate ester observed thereafter. Therefore, indanyl boronate esters were stored in a glovebox for longer periods of time. The diastereomeric ratio was determined by quantitative ${ }^{13} \mathrm{C}$ NMR. Assignment of the trans diastereomer products were confirmed by COSY and NOESY ${ }^{1} \mathrm{H}$ NMR.

\section{c. Cobalt Catalyzed Isomerization-Hydroboration on Gram Scale}

In an $\mathrm{N}_{2}$-atmosphere glovebox, a $40 \mathrm{~mL}$ vial was charged with a magnetic stir bar, $5.0 \mathrm{mmol}$ of substrate, $0.019 \mathrm{~g}$ of [Co]-1 $(0.050 \mathrm{mmol}, 1.0 \mathrm{~mol} \%)$, and $20 \mathrm{~mL}$ of toluene. HBPin $(0.73 \mathrm{~mL}$, $5.05 \mathrm{mmol}, 1.01$ equiv.) was then added to the reaction mixture. The vial was capped with a screw cap equipped with a Teflon septum, sealed with electrical tape, and brought out of the glove box and placed in a heating block set at $50^{\circ} \mathrm{C}$, and allowed to stir for $24 \mathrm{~h}$. The reaction was then quenched by exposure to air, the volatiles removed in vacuo, and the crude residue purified by flash column chromatography using hexanes/ethylacetate (gradient $0 \%$ to $5 \%$ to $10 \%$ ethyl acetate) to isolate the desired indanyl boronate ester. 


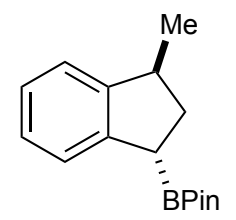

Trans-2-(3-methyl-2,3-dihydro-1 $H$-inden-1-yl)-4,4,5,5-tetramethyl-

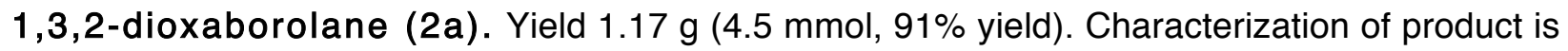
presented below in Section IV.<smiles>[18OH]C1CC(c2ccccc2)c2ccccc21</smiles>

Trans-2-(3-phenyl-2,3-dihydro-1 $H$-inden-1-yl)-4,4,5,5-tetramethyl1,3,2-dioxaborolane (2e). Yield $1.37 \mathrm{~g}(4.3 \mathrm{mmol}, 86 \%$ yield). Characterization of product is presented below in Section IV.

d. Uncatalyzed Hydroboration with 9-BBN
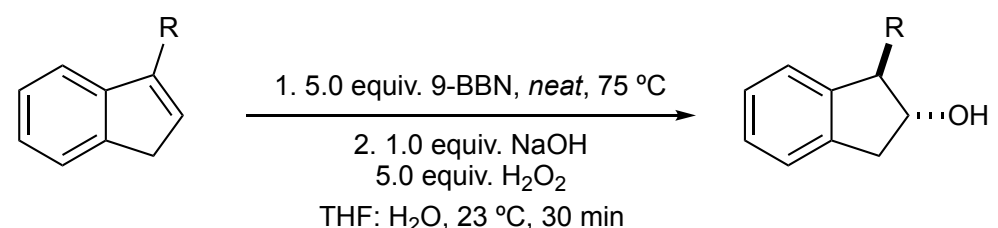

THF: $\mathrm{H}_{2} \mathrm{O}, 23^{\circ} \mathrm{C}, 30 \mathrm{~min}$

In an $\mathrm{N}_{2}$-atmosphere glovebox, a $4 \mathrm{~mL}$ vial was charged with $0.100 \mathrm{mmol}$ of indene and a stirbar. A 0.5 M solution of 9-borabicyclo[3.3.1]nonane (9-BBN) (5 equiv., $1.0 \mathrm{~mL}$ ) was added to the vial by syringe. The vial was then sealed with a cap equipped with a Teflon septum, sealed with electrical tape, and brought out of the glovebox. The vial was placed in a heating block and allowed to stir at $75{ }^{\circ} \mathrm{C}$ for $48 \mathrm{~h}$. The reaction was then allowed to cool to room temperature. Without exposing the solution to air, $\mathrm{NaOH}$ (1.0 M aqueous, 1.0 equiv.) and $\mathrm{H}_{2} \mathrm{O}_{2}\left(30 \%\right.$ in $\mathrm{H}_{2} \mathrm{O}$, 5.0 equiv) were added to the vial by syringe. The reaction was allowed to stir at $23{ }^{\circ} \mathrm{C}$ for 30 $\min$. The reaction was then diluted with $\mathrm{Et}_{2} \mathrm{O}(5 \mathrm{~mL})$. The aqueous layer was separated and extracted with $\mathrm{Et}_{2} \mathrm{O}(1 \times 5 \mathrm{~mL})$. The organic layers were then combined and washed with S33 
saturated $\mathrm{NaHCO}_{3}$, followed by brine, and dried over $\mathrm{Na}_{2} \mathrm{SO}_{4}$. Following filtration and removal of the volatiles in vacuo, the crude residue was then analyzed without further purification. The NMR yield was determined for the crude product using dichloromethane as an internal standard.<smiles>O[C@H]1Cc2ccccc2C1c1ccccc1</smiles>

Trans-1-phenyl-2,3-dihydro-1 $H$-inden-2-ol. Prepared according to the procedure above using $0.019 \mathrm{~g}(0.10 \mathrm{mmol})$ of $2 \mathrm{e}, 1 \mathrm{~mL}$ 9-BBN (0.5 $\mathrm{M}$ in THF, 5 equiv.), 0.10 $\mathrm{mL} \mathrm{NaOH}$ (1 $\mathrm{M}$ aqueous), and $0.057 \mathrm{~g} \mathrm{H}_{2} \mathrm{O}_{2}\left(30 \%\right.$ in $\left.\mathrm{H}_{2} \mathrm{O}\right)$. NMR yield $0.069 \mathrm{mmol}(69 \%)$ as a clear oil. ${ }^{1} \mathrm{H}$ and ${ }^{13} \mathrm{C}$ NMR data agree with values reported. ${ }^{44}$

${ }^{1} \mathrm{H}$ NMR $\left(400 \mathrm{MHz}, \mathrm{CDCl}_{3}, 23^{\circ} \mathrm{C}\right): \delta 7.38-7.12(\mathrm{~m}, 8 \mathrm{H}, \operatorname{Ar} H), 6.90(\mathrm{~d}, J=7.4 \mathrm{~Hz}, 1 \mathrm{H}, \operatorname{Ar} H)$, 4.46 (s, 1H, CHPh), 4.17 (br, 1H, CHOH), 3.22 (dd, J = 6.9, $15.6 \mathrm{~Hz}, 1 \mathrm{H}, \mathrm{CH}_{2}$ ), 2.87 (dd, J = 7.4, $\left.15.6 \mathrm{~Hz}, 1 \mathrm{H}, \mathrm{CH}_{2}\right), 2.02(\mathrm{br}, 1 \mathrm{H}, \mathrm{OH})$.

${ }^{13} \mathrm{C}\left\{{ }^{1} \mathrm{H}\right\}$ NMR $\left(101 \mathrm{MHz}, \mathrm{CDCl}_{3}, 23{ }^{\circ} \mathrm{C}\right): \delta 143.8(\operatorname{Ar} C), 142.1(\operatorname{Ar} C), 140.6(\operatorname{Ar} C), 128.7$ (ArH), $128.5(\mathrm{ArH}), 127.3(\mathrm{ArH}), 127.1(\mathrm{ArH}), 126.9(\mathrm{ArH}), 125.3(\mathrm{ArH}), 124.7(\mathrm{ArH}), 82.2$ (CHOH), $60.3(\mathrm{CHPh}), 40.2\left(\mathrm{CH}_{2}\right)$.<smiles>O[C@H]1[CH]c2ccccc2C1</smiles>

Trans-1-methyl-2,3-dihydro-1H-inden-2-ol. Prepared according to the procedure above using $0.013 \mathrm{~g}(0.10 \mathrm{mmol})$ of $2 \mathrm{a}, 1 \mathrm{~mL}$ 9-BBN (0.5 $\mathrm{M}$ in THF, 5 equiv. $), 0.10$ $\mathrm{mL} \mathrm{NaOH}$ (1 $\mathrm{M}$ aqueous), and $0.057 \mathrm{~g} \mathrm{H}_{2} \mathrm{O}_{2}\left(30 \%\right.$ in $\left.\mathrm{H}_{2} \mathrm{O}\right)$. NMR yield 0.052 mmol $(52 \%)$ as a clear oil. ${ }^{1} \mathrm{H}$ and ${ }^{13} \mathrm{C}$ NMR data agree with values reported. ${ }^{45}$

${ }^{1} \mathrm{H}$ NMR $\left(400 \mathrm{MHz}, \mathrm{CDCl}_{3}, 23{ }^{\circ} \mathrm{C}\right): \delta$ 7.13-7.07 (m, 4H, indanyl $\left.\mathrm{CH}\right), 4.07(\mathrm{q}, \mathrm{J}=6.3 \mathrm{~Hz}, 1 \mathrm{H}$, $\mathrm{CHOH}), 3.25-2.75(\mathrm{~m}, 2 \mathrm{H}, \mathrm{PhCH}), 3.10\left(\mathrm{p}, \mathrm{J}=6.7 \mathrm{~Hz}, 1 \mathrm{H}, \mathrm{CH}_{2}\right), 2.14(\mathrm{br}, 1 \mathrm{H}, \mathrm{OH}), 1.28(\mathrm{~d}, \mathrm{~J}=$ $\left.6.9 \mathrm{~Hz}, 1 \mathrm{H}, \mathrm{CH}_{3}\right)$. 
${ }^{13} \mathrm{C}\left\{{ }^{1} \mathrm{H}\right\}$ NMR $\left(101 \mathrm{MHz}, \mathrm{CDCl}_{3}, 23^{\circ} \mathrm{C}\right): \delta 145.9$ (phenyl or indanyl $C$ ), 140.2 (phenyl or indanyl C), 126.6 (indanyl $\mathrm{CH}$ ), 124.5 (indanyl $\mathrm{CH}$ ), 123.4 (indanyl $\mathrm{CH}$ ), $80.1(\mathrm{CHOH}), 46.9\left(\mathrm{CHCH}_{3}\right)$, $39.9\left(\mathrm{CH}_{2}\right), 17.1\left(\mathrm{CH}_{3}\right)$.

\section{Characterization of Indanyl Boronate Esters}<smiles>CC1C[C@H](Br)c2ccccc21</smiles>

Trans-2-(3-methyl-2,3-dihydro-1 H-inden-1-yl)-4,4,5,5-tetramethyl-

1,3,2-dioxaborolane (2a). Prepared according to the general procedure using $0.010 \mathrm{~g}$ $(0.025 \mathrm{mmol}, 5 \mathrm{~mol} \%$ loading $)$ of catalyst, $0.065 \mathrm{~g}(0.500 \mathrm{mmol})$ of substrate, $0.067 \mathrm{~g}(0.525$ $\mathrm{mmol}$ ) of $\mathrm{HBPin}$, and $5.0 \mathrm{~mL}$ of toluene, the reaction was allowed to stir at $23^{\circ} \mathrm{C}$. After $24 \mathrm{~h}$, the reaction mixture was quenched. Purification by flash column chromatography (silica gel; gradient $0 \%$ to $5 \%$ to $10 \%$ ethyl acetate in hexanes) yielded $0.116 \mathrm{~g}(0.449 \mathrm{mmol}, 90 \%)$ of the product as a colorless oil.

${ }^{1} \mathrm{H}$ NMR $\left(500 \mathrm{MHz}, \mathrm{CDCl}_{3}, 23^{\circ} \mathrm{C}\right): \delta 7.29(\mathrm{~m}, 1 \mathrm{H}$, indanyl $\mathrm{CH}), 7.20(\mathrm{~m}, 1 \mathrm{H}$, indanyl $\mathrm{CH}), 7.16$ (overlapping d, $J=3.3,5.5 \mathrm{~Hz}, 2 \mathrm{H}$, indanyl $\mathrm{CH}$ ), $3.32(\mathrm{~m}, 1 \mathrm{H}, 3$-indanyl $\mathrm{CH}$ ), $2.84(\mathrm{dd}, J=6.0$, 8.6 Hz, 1H, 1-indanyl CHBPin), 2.41 (m, 1H, 2-indanyl $\mathrm{CH}$ ), 1.85 (ddd, J = 6.7, 8.9, $12.3 \mathrm{~Hz}, 1 \mathrm{H}$, 2-indanyl $\mathrm{CH}), 1.29\left(\mathrm{~d}, \mathrm{~J}=6.9 \mathrm{~Hz}, 3 \mathrm{H}, \mathrm{CH}_{3}\right), 1.26\left(\mathrm{~s}, 6 \mathrm{H}, \mathrm{BPin} \mathrm{CH}_{3}\right), 1.25\left(\mathrm{~s}, 6 \mathrm{H}, \mathrm{BPin} \mathrm{CH}_{3}\right)$.

${ }^{13} \mathrm{C}\left\{{ }^{1} \mathrm{H}\right\}$ NMR (126 MHz, $\mathrm{CDCl}_{3}, 23{ }^{\circ} \mathrm{C}$ ): $\delta 148.63$ (indanyl C), 144.72 (indanyl C), 126.22 (indanyl $\mathrm{CH}$ ), 125.65 (indanyl $\mathrm{CH}$ ), 124.34 (indanyl $\mathrm{CH}$ ), 123.31 (indanyl $\mathrm{CH}$ ), 83.34 (BPin $\mathrm{C}$ ), 39.52 (3-indanyl $\mathrm{CHCH}_{3}$ ), 36.74 (2-indanyl $\mathrm{CH}_{2}$ ), 28.22 (indanyl $\mathrm{CHBPin}$ ), 24.90 (BPin $\mathrm{CH}_{3}$ ), $24.73\left(\mathrm{BPin} \mathrm{CH}_{3}\right), 20.27\left(\mathrm{CH}_{3}\right)$.

${ }^{11} \mathrm{~B}$ NMR $\left(96 \mathrm{MHz}, \mathrm{CDCl}_{3}, 23^{\circ} \mathrm{C}\right): \delta 33.48$.

HRMS (ESI+) $m / z$ calculated for $\mathrm{C}_{16} \mathrm{H}_{23} \mathrm{BO}_{2}{ }^{+}[\mathrm{M}]^{+} 258.17911$, found $\mathrm{m} / \mathrm{z} 258.1811$. 


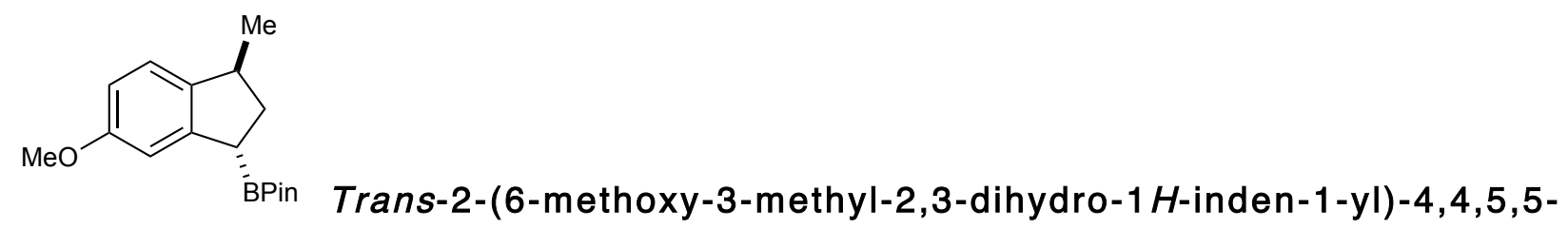

tetramethyl-1,3,2-dioxaborolane (2b). Note: product is prone to protodeborylation on silica gel. Attempts to isolate by flash column chromatography resulted in isolation of indane product. Prepared according to the general procedure using $0.010 \mathrm{~g}(0.025 \mathrm{mmol}, 5 \mathrm{~mol} \%$ loading $)$ of catalyst, $0.080 \mathrm{~g}(0.500 \mathrm{mmol})$ of substrate, $0.067 \mathrm{~g}(0.525 \mathrm{mmol})$ of HBPin, and 5.0 $\mathrm{mL}$ of toluene, the reaction was allowed to stir at $23^{\circ} \mathrm{C}$. After $24 \mathrm{~h}$, the reaction mixture was concentrated in vacuo. The residue was then diluted with pentane $(10 \mathrm{~mL})$ in the glove box, and the reaction mixture was filtered through celite on a fritted glass filter. The filtrate was concentrated in vacuo and exposed to air. The product was isolated as a colorless oil to yield $0.140 \mathrm{~g}(0.486 \mathrm{mmol}, 97 \%)$.

${ }^{1} \mathrm{H}$ NMR $\left(500 \mathrm{MHz}, \mathrm{CDCl}_{3}, 23^{\circ} \mathrm{C}\right): \delta 7.07(\mathrm{~d}, J=8.2 \mathrm{~Hz}, 1 \mathrm{H}$, indanyl $\mathrm{CH}), 6.86(\mathrm{~d}, J=2.3 \mathrm{~Hz}$, $1 \mathrm{H}$, indanyl $\mathrm{CH}), 6.70(\mathrm{dd}, J=2.5,8.9 \mathrm{~Hz}, 1 \mathrm{H}$, indanyl $\mathrm{CH}), 3.80\left(\mathrm{~s}, 3 \mathrm{H}\right.$, methoxy $\left.\mathrm{CH}_{3}\right), 3.25(\mathrm{~m}$, 1H, 3-indanyl $\mathrm{CH}$ ), 2.80 (dd, $J=5.9,8.7 \mathrm{~Hz}, 1 \mathrm{H}, 1$-indanyl CHBPin), 2.41 (ddd, $J=5.8,7.8$, $12.2 \mathrm{~Hz}, 1 \mathrm{H}, 2$-indanyl $\mathrm{CH}), 1.83(\mathrm{~m}, 1 \mathrm{H}, 2$-indanyl $\mathrm{CH}), 1.26\left(\mathrm{~s}, 6 \mathrm{H}, \mathrm{BPin} \mathrm{CH}_{3}\right), 1.25(\mathrm{~s}, 6 \mathrm{H}$, BPin $\mathrm{CH}_{3}$ ), 1.24 (obscured d, 3H, $\mathrm{CH}_{3}$ ).

${ }^{13} \mathrm{C}\left\{{ }^{1} \mathrm{H}\right\}$ NMR (126 MHz, $\mathrm{CDCl}_{3}, 23{ }^{\circ} \mathrm{C}$ ): $\delta 158.62$ (indanyl C), 146.24 (indanyl C), 140.89 (indanyl $C$ ), 123.65 (indanyl $\mathrm{CH}$ ), 111.34 (indanyl $\mathrm{CH}$ ), 109.94 (indanyl $\mathrm{CH}$ ), 83.33 (BPin $C$ ), $55.39\left(-\mathrm{OCH}_{3}\right), 38.67$ (3-indanyl $\mathrm{CHCH}_{3}$ ), 37.12 (2-indanyl $\mathrm{CH}_{2}$ ), 28.40 (1-indanyl $\left.\mathrm{CBPin}\right), 24.89$ (BPin $\left.\mathrm{CH}_{3}\right)$, $24.66\left(\mathrm{BPin} \mathrm{CH}_{3}\right), 20.55\left(\mathrm{CH}_{3}\right)$.

${ }^{11}$ B NMR $\left(96 \mathrm{MHz}, \mathrm{CDCl}_{3}, 23^{\circ} \mathrm{C}\right): \delta 33.38$.

HRMS (ESI+) $m / z$ calculated for $\mathrm{C}_{17} \mathrm{H}_{25} \mathrm{BO}_{3}{ }^{+}[\mathrm{M}]^{+}$288.1897, found $\mathrm{m} / \mathrm{z} 288.1903$. 


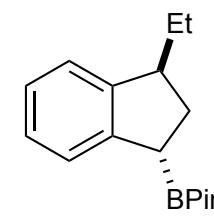

Trans-2-(3-ethyl-2,3-dihydro-1 $H$-inden-1-yl)-4,4,5,5-tetramethyl-1,3,2-

dioxaborolane (2c). Prepared according to the general procedure using $0.010 \mathrm{~g}(0.025$ $\mathrm{mmol}, 5 \mathrm{~mol} \%$ loading $)$ of catalyst, $0.072 \mathrm{~g}(0.500 \mathrm{mmol})$ of substrate, $0.067 \mathrm{~g}(0.525 \mathrm{mmol})$ of $\mathrm{HBPin}$, and $5.0 \mathrm{~mL}$ of toluene, the reaction was allowed to stir at $23^{\circ} \mathrm{C}$. After $24 \mathrm{~h}$, the reaction mixture was quenched. Purification by flash column chromatography (silica gel; gradient $0 \%$ to $5 \%$ to $10 \%$ ethyl acetate in hexanes) yielded $0.124 \mathrm{~g}(0.456 \mathrm{mmol}, 91 \%)$ of the product as a colorless oil.

${ }^{1} \mathrm{H}$ NMR $\left(500 \mathrm{MHz}, \mathrm{CDCl}_{3}, 23^{\circ} \mathrm{C}\right): \delta 7.24(\mathrm{~m}, 1 \mathrm{H}$, indanyl $\mathrm{CH}), 7.17(\mathrm{~m}, 1 \mathrm{H}$, indanyl $\mathrm{CH}), 7.11$ (m, 2H, indanyl $\mathrm{CH}), 3.07(\mathrm{~m}, 1 \mathrm{H}, 3$-indanyl $\mathrm{CH}), 2.78(\mathrm{t}, \mathrm{J}=8.0 \mathrm{~Hz}, 1 \mathrm{H}, 1$-indanyl $\mathrm{CHBPin})$, $2.32(\mathrm{~m}, 1 \mathrm{H}, 2$-indanyl $\mathrm{CH}), 1.91(\mathrm{~m}, 1 \mathrm{H}, 2$-indanyl $\mathrm{CH}), 1.74\left(\mathrm{~m}, 1 \mathrm{H},-\mathrm{CH}_{2} \mathrm{CH}_{3}\right), 1.46(\mathrm{~m}, 1 \mathrm{H},-$ $\left.\mathrm{CH}_{2} \mathrm{CH}_{3}\right), 1.24\left(\mathrm{~s}, 6 \mathrm{H}\right.$, BPin $\left.\mathrm{CH}_{3}\right), 1.23\left(\mathrm{~s}, 6 \mathrm{H}, \mathrm{BPin} \mathrm{CH}_{3}\right), 0.98\left(\mathrm{t}, \mathrm{J}=7.4 \mathrm{~Hz}, 3 \mathrm{H},-\mathrm{CH}_{2} \mathrm{CH}_{3}\right)$.

${ }^{13} \mathrm{C}\left\{{ }^{1} \mathrm{H}\right\}$ NMR (126 MHz, $\mathrm{CDCl}_{3}, 23{ }^{\circ} \mathrm{C}$ ): $\delta 146.7$ (indanyl C), 145.0 (indanyl C), 126.3 (indanyl $\mathrm{CH}$ ), 125.5 (indanyl $\mathrm{CH}$ ), 124.5 (indanyl $\mathrm{CH}$ ), 124.0 (indanyl $\mathrm{CH}$ ), 83.4 (BPin $\mathrm{C}$ ), 46.7 (3-indanyl CHEt), 33.7 (2-indanyl $\left.\mathrm{CH}_{2}\right), 28.0\left(-\mathrm{CH}_{2} \mathrm{CH}_{3}\right), 25.0\left(\mathrm{BPin} \mathrm{CH}_{3}\right), 24.8\left(\mathrm{BPin} \mathrm{CH}_{3}\right), 12.3$ ($\left.\mathrm{CH}_{2} \mathrm{CH}_{3}\right)$. The carbon attached to -BPin was not observed.

${ }^{11} \mathrm{~B}$ NMR $\left(96 \mathrm{MHz}, \mathrm{CDCl}_{3}, 23^{\circ} \mathrm{C}\right): \delta 33.66$.

HRMS (ESI+) $m / z$ calculated for $\mathrm{C}_{17} \mathrm{H}_{25} \mathrm{BO}_{2}{ }^{+}[\mathrm{M}]^{+} 272.1948$, found $m / z 272.1977$.

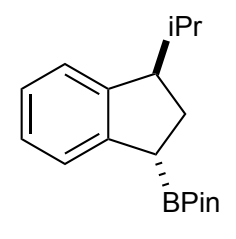

Trans-2-(3-isopropyl-2,3-dihydro-1 $H$-inden-1-yl)-4,4,5,5-tetramethyl-

1,3,2-dioxaborolane (2d). Prepared according to the general procedure using $0.010 \mathrm{~g}$ (0.025 mmol, $5 \mathrm{~mol} \%$ loading) of catalyst, $0.079 \mathrm{~g}(0.500 \mathrm{mmol})$ of substrate, $0.067 \mathrm{~g}(0.525$ S37 
mmol) of HBPin, and $5.0 \mathrm{~mL}$ of toluene, the reaction was allowed to stir at $23^{\circ} \mathrm{C}$. After $24 \mathrm{~h}$, the reaction mixture was quenched. Purification by flash column chromatography (silica gel; gradient $0 \%$ to $5 \%$ to $10 \%$ ethyl acetate in hexanes) yielded $0.125 \mathrm{~g}(0.437 \mathrm{mmol}, 87 \%)$ of the product as a colorless oil.

${ }^{1} \mathrm{H}$ NMR $\left(500 \mathrm{MHz}, \mathrm{CDCl}_{3}, 23^{\circ} \mathrm{C}\right): \delta 7.30(\mathrm{~d}, J=6.6 \mathrm{~Hz}, 1 \mathrm{H}$, indanyl $\mathrm{CH}), 7.21(\mathrm{~d}, J=7.0 \mathrm{~Hz}$, $1 \mathrm{H}$, indanyl $\mathrm{CH}), 7.15(\mathrm{~m}, 2 \mathrm{H}$, indanyl $\mathrm{CH}), 3.13(\mathrm{~m}, 1 \mathrm{H}, 3$-indanyl $\mathrm{CH}), 2.79(\mathrm{t}, J=8.6 \mathrm{~Hz}, 1 \mathrm{H}$, 1-indanyl CHBPin), $2.22(\mathrm{~m}, 1 \mathrm{H}, 2$-indanyl $\mathrm{CH}), 2.12(\mathrm{~m}, 1 \mathrm{H}, 2$-indanyl $\mathrm{CH}), 2.03(\mathrm{~m}, 1 \mathrm{H}, \mathrm{iPr}$ methine), 1.29 (s, 6H, BPin $\mathrm{CH}_{3}$ ), $1.28\left(\mathrm{~s}, 6 \mathrm{H}\right.$, BPin $\left.\mathrm{CH}_{3}\right), 1.02\left(\mathrm{~d}, J=6.8 \mathrm{~Hz}, 3 \mathrm{H}, \mathrm{iPr} \mathrm{CH}_{3}\right), 0.84$ (d, $J=6.8 \mathrm{~Hz}, 3 \mathrm{H}$, iPr $\mathrm{CH}_{3}$ ).

${ }^{13} \mathrm{C}\left\{{ }^{1} \mathrm{H}\right\}$ NMR (126 MHz, $\mathrm{CDCl}_{3}, 23{ }^{\circ} \mathrm{C}$ ): $\delta 146.50$ (indanyl $\mathrm{C}$ ), 145.43 (indanyl $\mathrm{C}$ ), 126.28 (indanyl $\mathrm{CH}$ ), 125.34 (indanyl $\mathrm{CH}$ ), 124.67 (indanyl $\mathrm{CH}$ ), 124.37 (indanyl $\mathrm{CH}$ ), 83.35 (BPin $\mathrm{C}$ ), 51.40 (3-indanyl CHiPr), 31.88 (iPr methine), 29.53 (2-indanyl $\mathrm{CH}_{2}$ ), 28.74 (indenyl $\mathrm{CHBPin}$ ), 24.94 (BPin $\left.\mathrm{CH}_{3}\right), 24.79\left(\mathrm{BPin} \mathrm{CH}_{3}\right), 21.21\left(\mathrm{iPr} \mathrm{CH}_{3}\right), 18.44\left(\mathrm{iPr} \mathrm{CH}_{3}\right)$.

${ }^{11} \mathrm{~B}$ NMR $\left(96 \mathrm{MHz}, \mathrm{CDCl}_{3}, 23{ }^{\circ} \mathrm{C}\right): \delta 33.54$.

HRMS (ESI+) $m / z$ calculated for $\mathrm{C}_{18} \mathrm{H}_{27} \mathrm{BO}_{2}{ }^{+}[\mathrm{M}]^{+}$286.2104, found $\mathrm{m} / \mathrm{z}$ 286.2095.

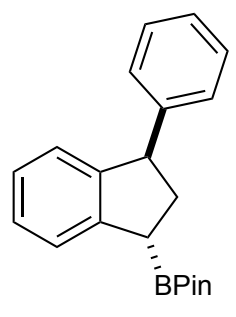

Trans-2-(3-phenyl-2,3-dihydro-1 H-inden-1-yl)-4,4,5,5-tetramethyl-

1,3,2-dioxaborolane (2e). Prepared according to the general procedure using $0.010 \mathrm{~g}$ $(0.025 \mathrm{mmol}, 5 \mathrm{~mol} \%$ loading $)$ of catalyst, $0.096 \mathrm{~g}(0.500 \mathrm{mmol})$ of substrate, $0.067 \mathrm{~g}(0.525$ mmol) of HBPin, and $5.0 \mathrm{~mL}$ of toluene, the reaction was allowed to stir at $23^{\circ} \mathrm{C}$. After $24 \mathrm{~h}$, the reaction mixture was quenched. Purification by flash column chromatography (silica gel; gradient $0 \%$ to $5 \%$ to $10 \%$ ethyl acetate in hexanes) yielded $0.153 \mathrm{~g}(0.478 \mathrm{mmol}, 96 \%)$ of the S38 
product as a colorless solid. Further recrystallization of the product from a saturated solution of hexanes at $-35^{\circ} \mathrm{C}$ for 2 days yielded crystals suitable for X-Ray diffraction.

${ }^{1} \mathrm{H}$ NMR $\left(500 \mathrm{MHz}, \mathrm{CDCl}_{3}, 23^{\circ} \mathrm{C}\right): \delta 7.41(\mathrm{~d}, J=7.5 \mathrm{~Hz}, 1 \mathrm{H}$, indanyl $\mathrm{CH}), 7.34(\mathrm{t}, J=7.2 \mathrm{~Hz}$, $2 \mathrm{H}, o$ or $m$-Ph $\mathrm{CH}$ ), 7.27-7.21 (overlapping $\mathrm{m}, 4 \mathrm{H}, \mathrm{Ph}$ and indanyl $\mathrm{CH}$ ), $7.16(\mathrm{t}, \mathrm{J}=7.3 \mathrm{~Hz}, 1 \mathrm{H}$, indanyl $\mathrm{CH}$ ), $7.05(\mathrm{~d}, J=7.7 \mathrm{~Hz}, 1 \mathrm{H}$, indanyl $\mathrm{CH}$ ), $4.48(\mathrm{t}, J=7.7 \mathrm{~Hz}, 1 \mathrm{H}, 3$-indanyl $\mathrm{CHPh}), 2.96$ (dd, $J=5.7,8.8 \mathrm{~Hz}, 1 \mathrm{H}, 1$-indanyl CHBPin), $2.70(\mathrm{~m}, 1 \mathrm{H}, 2$-indanyl $\mathrm{CH}$ ), 2.26 (m, 1H, 2-indanyl $\mathrm{CH}), 1.27\left(\mathrm{~s}, 6 \mathrm{H}, \mathrm{BPin} \mathrm{CH}_{3}\right), 1.26\left(\mathrm{~s}, 6 \mathrm{H}, \mathrm{BPin} \mathrm{CH}_{3}\right)$.

${ }^{13} \mathrm{C}\left\{{ }^{1} \mathrm{H}\right\}$ NMR $\left(126 \mathrm{MHz}, \mathrm{CDCl}_{3}, 23{ }^{\circ} \mathrm{C}\right.$ ): $\delta 146.39$ (phenyl or indanyl C), 145.91 (phenyl or indanyl C), 145.45 (phenyl or indanyl C), 128.45 (o or $m$-Ph $C H$ ), 128.07 (o or $m$-Ph $\mathrm{CH}$ ), 126.69 (Ph or indanyl $\mathrm{CH}$ ), 126.20 ( $\mathrm{Ph}$ or indanyl $\mathrm{CH}$ ), 125.89 (indanyl $\mathrm{CH}$ ), 125.09 (indanyl $\mathrm{CH}$ ), 124.34 (indanyl $\mathrm{CH}$ ), 83.47 (BPin $\mathrm{C}$ ), 51.42 (3-indanyl $\mathrm{CHPh}$ ), 38.48 (2-indanyl $\mathrm{CH}_{2}$ ), 28.79 (indenyl $\mathrm{CHBPin}$ ), $24.92\left(\mathrm{BPin} \mathrm{CH}_{3}\right), 24.73\left(\mathrm{BPin} \mathrm{CH}_{3}\right)$.

${ }^{11} \mathrm{~B}$ NMR $\left(96 \mathrm{MHz}, \mathrm{CDCl}_{3}, 23^{\circ} \mathrm{C}\right): \delta 33.41$.

HRMS (ESI+) $m / z$ calculated for $\mathrm{C}_{21} \mathrm{H}_{25} \mathrm{BO}_{2}{ }^{+}[\mathrm{M}]^{+} 320.1948$, found $\mathrm{m} / z 320.2008$.

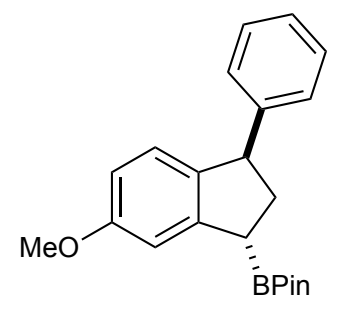

\section{2-(6-methoxy-3-phenyl-2,3-dihydro- $1 H$-inden-1-yl)-4,4,5,5-}

tetramethyl-1,3,2-dioxaborolane (2f). Note: product is prone to protodeborylation on silica gel. Attempts to isolate by flash column chromatography resulted in isolation of indane product. Prepared according to the general procedure using $0.010 \mathrm{~g}(0.025 \mathrm{mmol}, 5 \mathrm{~mol} \%$ loading $)$ of catalyst, $0.111 \mathrm{~g}(0.500 \mathrm{mmol})$ of substrate, $0.067 \mathrm{~g}(0.525 \mathrm{mmol})$ of HBPin, and $5.0 \mathrm{~mL}$ of toluene, the reaction was allowed to stir at $23{ }^{\circ} \mathrm{C}$. After $24 \mathrm{~h}$, the reaction mixture was concentrated in vacuo. The residue was then diluted with pentane $(10 \mathrm{~mL})$ in the glove box, and S39 
the reaction mixture was filtered through celite on a fritted glass filter. The filtrate was concentrated in vacuo and exposed to air. The product was isolated as off-white crystals to yield $0.140 \mathrm{~g}(0.486 \mathrm{mmol}, 97 \%)$.

${ }^{1} \mathrm{H}$ NMR $\left(500 \mathrm{MHz}, \mathrm{CDCl}_{3}, 23{ }^{\circ} \mathrm{C}\right): \delta 7.27(\mathrm{~m}, 2 \mathrm{H}, o$ - or $m-\mathrm{Ph} \mathrm{CH}), 7.20(\mathrm{~m}, 1 \mathrm{H}, p-\mathrm{Ph} \mathrm{CH}), 7.15$ (m, $2 \mathrm{H}, o$ - or $m$-Ph $\mathrm{CH}$ ), 6.89 (overlapping $\mathrm{m}, 2 \mathrm{H}$, indanyl $\mathrm{CH}$ ), $6.65(\mathrm{dd}, J=2.5,8.3 \mathrm{~Hz}, 1 \mathrm{H}$, indanyl $\mathrm{CH}$ ), 4.38 (m, 1H, 3-indanyl CHPh), 3.80 (s, 3H, MeO-), 2.88 (dd, J = 6.0, $8.7 \mathrm{~Hz}, 1 \mathrm{H}, 1$ indanyl CHBPin), $2.66(\mathrm{~m}, 1 \mathrm{H}, 2$-indanyl $\mathrm{CH}), 2.22(\mathrm{~m}, 1 \mathrm{H}, 2$-indanyl $\mathrm{CH}), 1.25(\mathrm{~s}, 6 \mathrm{H}$, BPin $\left.\mathrm{CH}_{3}\right), 1.24\left(\mathrm{~s}, 6 \mathrm{H}\right.$, BPin $\left.\mathrm{CH}_{3}\right)$.

${ }^{13} \mathrm{C}\left\{{ }^{1} \mathrm{H}\right\}$ NMR $\left(126 \mathrm{MHz}, \mathrm{CDCl}_{3}, 23{ }^{\circ} \mathrm{C}\right): \delta 159.02$ (phenyl or indanyl C), 147.10 (phenyl or indanyl C), 146.35 (phenyl or indanyl C), 138.72 (phenyl or indanyl C), 128.46 (o or $m-\mathrm{Ph} \mathrm{CH}$ ), 127.99 (o or $m-\mathrm{Ph} C H$ ), $126.17(p-\mathrm{Ph} C H$ ), 125.59 (indanyl $\mathrm{CH}$ ), 111.86 (indanyl $\mathrm{CH}$ ), 109.80 (indanyl $\mathrm{CH}$ ), 83.55 (BPin $C$ ), 55.52 (MeO-), 50.62 (3-indanyl $\mathrm{CHPh}$ ), 38.95 (2-indanyl $\mathrm{CH}_{2}$ ), 29.02 (indanyl CHBPin), 25.02 (BPin $\mathrm{CH}_{3}$ ), 24.75 (BPin $\mathrm{CH}_{3}$ ).

${ }^{11} \mathrm{~B}$ NMR $\left(96 \mathrm{MHz}, \mathrm{CDCl}_{3}, 23^{\circ} \mathrm{C}\right): \delta 33.13$.

HRMS (ESI+) $m / z$ calculated for $\mathrm{C}_{22} \mathrm{H}_{27} \mathrm{BO}_{3}{ }^{+}[\mathrm{M}]^{+} 350.2053$, found $m / z$ 350.2060.

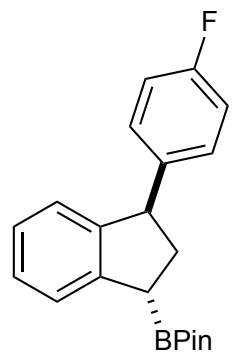

Trans-2-(3-(4-fluorophenyl)-2,3-dihydro-1 $H$-inden-1-yl)-4,4,5,5-

tetramethyl-1,3,2-dioxaborolane $(2 \mathrm{~g})$. Prepared according to the general procedure using $0.010 \mathrm{~g}(0.025 \mathrm{mmol}, 5 \mathrm{~mol} \%$ loading $)$ of catalyst, $0.105 \mathrm{~g}(0.500 \mathrm{mmol})$ of substrate, $0.067 \mathrm{~g}$ $(0.525 \mathrm{mmol})$ of HBPin, and $5.0 \mathrm{~mL}$ of toluene, the reaction was allowed to stir at $23^{\circ} \mathrm{C}$. After 24 $\mathrm{h}$, the reaction mixture was quenched. Purification by flash column chromatography (silica gel; 
gradient $0 \%$ to $5 \%$ to $10 \%$ ethyl acetate in hexanes) yielded $0.154 \mathrm{~g}(0.455 \mathrm{mmol}, 91 \%)$ of the product as a colorless oil.

${ }^{1} \mathrm{H}$ NMR $\left(500 \mathrm{MHz}, \mathrm{CDCl}_{3}, 23{ }^{\circ} \mathrm{C}\right): \delta 7.35(\mathrm{~d}, J=7.4 \mathrm{~Hz}, 1 \mathrm{H}$, indanyl $\mathrm{CH}), 7.20(\mathrm{t}, J=7.4 \mathrm{~Hz}$, $2 \mathrm{H}$, indanyl $\mathrm{CH}$ ), 7.12 (overlapping $\mathrm{m}, 3 \mathrm{H}$, aryl and indanyl $\mathrm{CH}$ ), 6.97 (apparent $\mathrm{t}, \mathrm{J}=8.5 \mathrm{~Hz}$, 3H, aryl or indanyl $\mathrm{CH}$ ), $4.45(\mathrm{t}, J=7.7 \mathrm{~Hz}, 1 \mathrm{H}, 3$-indanyl $\mathrm{CH}$ ), $2.92(\mathrm{dd}, J=5.7,8.6 \mathrm{~Hz}, 1 \mathrm{H}, 1$ indanyl $\mathrm{CH}), 2.67(\mathrm{~m}, 1 \mathrm{H}, 2$-indanyl $\mathrm{CH}), 2.19(\mathrm{~m}, 1 \mathrm{H}, 2$-indanyl $\mathrm{CH}), 1.26\left(\mathrm{~s}, 6 \mathrm{H}, \mathrm{BPin} \mathrm{CH}_{3}\right)$, $1.25\left(\mathrm{~s}, 6 \mathrm{H}\right.$, BPin $\left.\mathrm{CH}_{3}\right)$.

${ }^{13} \mathrm{C}\left\{{ }^{1} \mathrm{H}\right\}$ NMR $\left(126 \mathrm{MHz}, \mathrm{CDCl}_{3}, 23{ }^{\circ} \mathrm{C}\right): \delta 161.5(\mathrm{~d}, J=243.8 \mathrm{~Hz}$, aryl CF), 160.3 (indanyl $C$ ), 146.2 (indanyl C), 145.4 (indanyl C), 141.6 (d, $J=3.2 \mathrm{~Hz}$, ipso-aryl C), 129.5 (d, $J=7.8 \mathrm{~Hz}, 2-$ aryl $\mathrm{CH}$ ), 126.8 (indanyl $\mathrm{CH}$ ), 126.0 (indanyl $\mathrm{CH}$ ), 125.0 (indanyl $\mathrm{CH}$ ), 124.4 (indanyl $\mathrm{CH}$ ), 115.2

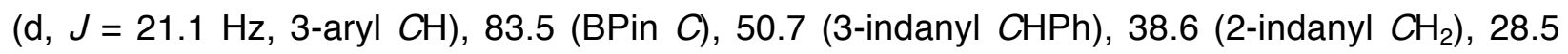
(indenyl CHBPin), 24.9 (BPin $\mathrm{CH}_{3}$ ), 24.7 (BPin $\mathrm{CH}_{3}$ ).

${ }^{11} \mathrm{~B}$ NMR $\left(96 \mathrm{MHz}, \mathrm{CDCl}_{3}, 23^{\circ} \mathrm{C}\right): \delta 33.89$.

${ }^{19} \mathrm{~F}$ NMR $\left(282 \mathrm{MHz}^{\mathrm{CDCl}} 3,23^{\circ} \mathrm{C}\right): \delta-117.3$.

HRMS (ESI+) $m / z$ calculated for $\mathrm{C}_{21} \mathrm{H}_{24} \mathrm{BFO}_{2}{ }^{+}[\mathrm{M}]^{+} 338.1853$, found $m / z$ 338.1851.

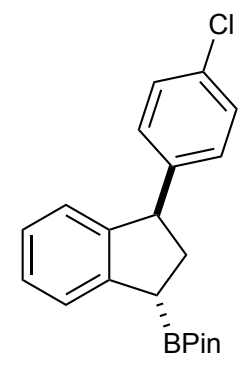

Trans-2-(3-(4-chlorophenyl)-2,3-dihydro-1 $H$-inden-1-yl)-4,4,5,5-

tetramethyl-1,3,2-dioxaborolane $(2 \mathrm{~h})$. Prepared according to the general procedure using $0.038 \mathrm{~g}(0.100 \mathrm{mmol}, 20 \mathrm{~mol} \%$ loading $)$ of catalyst, $0.113 \mathrm{~g}(0.500 \mathrm{mmol})$ of substrate, $0.077 \mathrm{~g}$ $(0.600 \mathrm{mmol})$ of HBPin, and $5.0 \mathrm{~mL}$ of toluene, the reaction was allowed to stir at $23^{\circ} \mathrm{C}$. After 24 $\mathrm{h}$, the reaction mixture was quenched. Purification by flash column chromatography (silica gel; 
gradient $0 \%$ to $5 \%$ to $10 \%$ ethyl acetate in hexanes) yielded $0.151 \mathrm{~g}(0.426 \mathrm{mmol}, 85.0 \%)$ of the product as a beige waxy solid.

${ }^{1} \mathrm{H}$ NMR $\left(500 \mathrm{MHz}, \mathrm{CDCl}_{3}, 23^{\circ} \mathrm{C}\right): \delta 7.35(\mathrm{~d}, J=7.4 \mathrm{~Hz}, 1 \mathrm{H}$, indanyl $\mathrm{CH}), 7.25(\mathrm{~d}, J=8.4 \mathrm{~Hz}$, $2 \mathrm{H}$, aryl $\mathrm{CH}$ ), $7.19(\mathrm{t}, \mathrm{J}=7.3 \mathrm{~Hz}, 1 \mathrm{H}$, indanyl $\mathrm{CH}$ ), 7.11-7.08 (overlapping $\mathrm{m}$, aryl and indanyl $\mathrm{CH}$ ), $6.96(\mathrm{~d}, \mathrm{~J}=7.3 \mathrm{~Hz}, 1 \mathrm{H}$, indanyl $\mathrm{CH}), 4.43(\mathrm{t}, J=7.7 \mathrm{~Hz}, 1 \mathrm{H}, 3$-indanyl $\mathrm{CH}$ ), 2.92 (dd, $J=$ 5.7, 9.0 Hz, 1H, 1-indanyl CH), 2.67 (ddd, J = 5.5, 8.4, $12.3 \mathrm{~Hz}, 1 \mathrm{H}, 2$-indanyl CH), 2.18 (ddd, J $=7.1,8.9,12.4 \mathrm{~Hz}, 1 \mathrm{H}, 2$-indanyl $\mathrm{CH}), 1.26\left(\mathrm{~s}, 6 \mathrm{H}, \mathrm{BPin} \mathrm{CH}_{3}\right), 1.25\left(\mathrm{~s}, 6 \mathrm{H}, \mathrm{BPin} \mathrm{CH}_{3}\right)$.

${ }^{13} \mathrm{C}\left\{{ }^{1} \mathrm{H}\right\}$ NMR $\left(126 \mathrm{MHz}, \mathrm{CDCl}_{3}, 23{ }^{\circ} \mathrm{C}\right.$ ): $\delta 145.89$ (indanyl C), 145.42 (indanyl C), 144.45 (indanyl C), 131.89 (indanyl C), 129.45 (aryl $C H$ ), 128.57 (aryl $C H$ ), 126.92 (indanyl $C H$ ), 126.02 (indanyl $\mathrm{CH}$ ), 124.99 (indanyl $\mathrm{CH}$ ), 124.45 (indanyl $\mathrm{CH}$ ), 83.57 (BPin $\mathrm{C}$ ), 50.81 (3-indanyl CHPh), 38.50 (2-indanyl $\mathrm{CH}_{2}$ ), 28.77 (indenyl $\left.C H B P i n\right), 24.93\left(\mathrm{BPin} \mathrm{CH}_{3}\right), 24.73\left(\mathrm{BPin} \mathrm{CH}_{3}\right)$.

${ }^{11}$ B NMR $\left(96 \mathrm{MHz}, \mathrm{CDCl}_{3}\right): \delta 33.00$.

HRMS (ESI+) $m / z$ calculated for $\mathrm{C}_{21} \mathrm{H}_{24} \mathrm{BClO}_{2}{ }^{+}[\mathrm{M}]^{+} 354.1558$, found $m / z$ 354.1578.

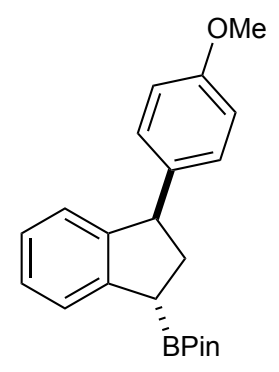

Trans-2-(3-(4-methoxyphenyl)-2,3-dihydro-1 $H$-inden-1-yl)-4,4,5,5tetramethyl-1,3,2-dioxaborolane (2i). Prepared according to the general procedure using $0.010 \mathrm{~g}(0.025 \mathrm{mmol}, 5 \mathrm{~mol} \%$ loading $)$ of catalyst, $0.111 \mathrm{~g}(0.500 \mathrm{mmol})$ of substrate, $0.067 \mathrm{~g}$ $(0.525 \mathrm{mmol})$ of HBPin, and $5.0 \mathrm{~mL}$ of toluene, the reaction was allowed to stir at $23^{\circ} \mathrm{C}$. After 24 $\mathrm{h}$, the reaction mixture was quenched. Purification by flash column chromatography (silica gel; gradient $0 \%$ to $5 \%$ to $10 \%$ ethyl acetate in hexanes) yielded $0.155 \mathrm{~g}(0.478 \mathrm{mmol}, 89 \%)$ of the product as a colorless oil. 
${ }^{1} \mathrm{H}$ NMR $\left(500 \mathrm{MHz}, \mathrm{CDCl}_{3}, 23^{\circ} \mathrm{C}\right): \delta 7.39(\mathrm{~d}, J=7.5 \mathrm{~Hz}, 1 \mathrm{H}$, indanyl $\mathrm{CH}), 7.22(\mathrm{t}, J=6.9 \mathrm{~Hz}$, $1 \mathrm{H}$, indanyl $\mathrm{CH}$ ), 7.15 (overlapping $\mathrm{m}, 3 \mathrm{H}, \mathrm{Ar}$ and indanyl $\mathrm{CH}$ ), $7.03(\mathrm{~d}, J=7.3 \mathrm{~Hz}, 1 \mathrm{H}$, indanyl CH), $6.88(\mathrm{~d}, J=8.7 \mathrm{~Hz}, 1 \mathrm{H}, \mathrm{Ar} \mathrm{CH}), 4.47(\mathrm{t}, J=7.7 \mathrm{~Hz}, 1 \mathrm{H}, 3$-indanyl CHPh), 2.97 (dd, J = 5.7, $8.8 \mathrm{~Hz}, 1 \mathrm{H}, 1$-indanyl CHBPin), $2.71(\mathrm{~m}, 1 \mathrm{H}, 2$-indanyl $\mathrm{CH}), 2.26(\mathrm{~m}, 1 \mathrm{H}, 2$-indanyl $\mathrm{CH}), 1.30(\mathrm{~s}$, 6H, BPin $\left.\mathrm{CH}_{3}\right), 1.29\left(\mathrm{~s}, 6 \mathrm{H}\right.$, BPin $\left.\mathrm{CH}_{3}\right)$.

${ }^{13} \mathrm{C}\left\{{ }^{1} \mathrm{H}\right\}$ NMR (126 MHz, $\left.\mathrm{CDCl}_{3}, 23{ }^{\circ} \mathrm{C}\right): \delta 158.08$ (Ar or indanyl C), 146.67 (Ar or indanyl C), 145.31 (Ar or indanyl C), 137.99 (Ar or indanyl C), $128.95(\mathrm{Ar} C \mathrm{H}), 126.58$ (indanyl $\mathrm{CH}$ ), 125.84 (indanyl $\mathrm{CH}$ ), 124.99 (indanyl $\mathrm{CH}$ ), 124.28 (indanyl $\mathrm{CH}$ ), $113.82(\mathrm{Ar} \mathrm{CH}$ ), 83.42 (BPin $\mathrm{C}$ ), 55.25 (-OMe), 50.58 (3-indanyl CHAr), 38.61 (2-indanyl $\mathrm{CH}_{2}$ ), 28.79 (indanyl CHBPin), 24.92 (BPin $\left.\mathrm{CH}_{3}\right), 24.73$ (BPin $\mathrm{CH}_{3}$ ).

${ }^{11}$ B NMR (96 MHz, $\left.\mathrm{CDCl}_{3}\right): \delta 33.40$.

HRMS (ESI+) $m / z$ calculated for $\mathrm{C}_{22} \mathrm{H}_{27} \mathrm{BO}_{3}{ }^{+}\left(\mathrm{M}^{+}\right)$350.2053, found $\mathrm{m} / \mathrm{z}$ 350.2076.

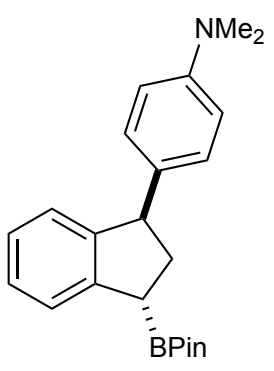

Trans-N,N-dimethyl-4-(3-(4,4,5,5-tetramethyl-1,3,2-dioxaborolan2-yl)-2,3-dihydro-1 H-inden-1-yl)aniline (2j). Note: product is prone to decomposition in air. Attempts to isolate by flash column chromatography resulted in mixtures of the desired product with protodeborylated product and unidentified decomposition products. Isolation was accomplished under inert atmosphere. Prepared according to the general procedure using $0.010 \mathrm{~g}(0.025 \mathrm{mmol}, 5 \mathrm{~mol} \%$ loading $)$ of catalyst, $0.118 \mathrm{~g}(0.500 \mathrm{mmol})$ of substrate, $0.067 \mathrm{~g}$ $(0.525 \mathrm{mmol})$ of HBPin, and $5.0 \mathrm{~mL}$ of toluene, the reaction was allowed to stir at $23^{\circ} \mathrm{C}$. After 24 $\mathrm{h}$, the volatiles were removed in vacuo. The residue was dissolved in pentane and filtered 
through celite on a fritted glass filter. The volatiles were again removed in vacuo and the resulting oil was dissolved in hexanes. Recrystallization at $-35^{\circ} \mathrm{C}$ yielded $0.120 \mathrm{~g}(0.330 \mathrm{mmol}$, $66 \%$ yield) of the desired product as an off-white solid.

${ }^{1} \mathrm{H}$ NMR $\left(400 \mathrm{MHz}, \mathrm{C}_{6} \mathrm{D}_{6}, 23{ }^{\circ} \mathrm{C}\right): \delta 7.57(\mathrm{~d}, J=7.8 \mathrm{~Hz}, 1 \mathrm{H}$, indanyl $\mathrm{CH}), 7.16(\mathrm{t}, \mathrm{J}=7.5 \mathrm{~Hz}$, $1 \mathrm{H}$, indanyl $\mathrm{CH}$ ), 7.10 (overlapping $\mathrm{m}, 3 \mathrm{H}, \mathrm{Ar}$ and indanyl $\mathrm{CH}$ ), $7.05(\mathrm{t}, \mathrm{J}=7.3 \mathrm{~Hz}, 1 \mathrm{H}$, indanyl $\mathrm{CH}), 6.58(\mathrm{~d}, J=8.8 \mathrm{~Hz}, 2 \mathrm{H}, \mathrm{Ar} \mathrm{CH}), 4.62(\mathrm{t}, J=8.1 \mathrm{~Hz}, 1 \mathrm{H}, 3$-indanyl CHAr), 3.08 (dd, $J=4.3$, $8.9 \mathrm{~Hz}, 1 \mathrm{H}, 1$-indanyl CHBPin), $2.92(\mathrm{~m}, 1 \mathrm{H}, 2$-indanyl $\mathrm{CH}), 2.53\left(\mathrm{~s}, 6 \mathrm{H}, \mathrm{N}\left(\mathrm{CH}_{3}\right)_{2}\right), 2.36(\mathrm{~m}, 1 \mathrm{H}$, 2-indanyl $\mathrm{CH}$ ), $1.02\left(\mathrm{~s}, 6 \mathrm{H}\right.$, BPin $\left.\mathrm{CH}_{3}\right), 1.01\left(\mathrm{~s}, 6 \mathrm{H}, \mathrm{BPin} \mathrm{CH}_{3}\right)$.

${ }^{13} \mathrm{C}\left\{{ }^{1} \mathrm{H}\right\}$ NMR $\left(101 \mathrm{MHz}, \mathrm{C}_{6} \mathrm{D}_{6}, 23^{\circ} \mathrm{C}\right): \delta 149.74$ (Ar or indanyl C), 147.58 (Ar or indanyl C), 145.84 (Ar or indanyl C), 134.30 (Ar or indanyl C), $129.05(\mathrm{Ar} \mathrm{CH}), 126.79$ (indanyl $\mathrm{CH}$ ), 126.20 (indanyl $\mathrm{CH}$ ), 125.56 (indanyl $\mathrm{CH}$ ), 124.62 (indanyl $\mathrm{CH}$ ), $113.49(\mathrm{Ar} \mathrm{CH}$ ), 83.30 (BPin $\mathrm{C}$ ), 51.30 (3-indanyl $\mathrm{CHPh}$ ), $40.61\left(\mathrm{~N}\left(\mathrm{CH}_{3}\right)_{2}\right), 39.45$ (2-indanyl $\mathrm{CH}_{2}$ ), 29.50 (1-indanyl CHBPin), 24.88 (BPin $\mathrm{CH}_{3}$ ), 24.71 (BPin $\mathrm{CH}_{3}$ ).

${ }^{11}$ B NMR $\left(96 \mathrm{MHz}, \mathrm{CDCl}_{3}\right): \delta 33.95$.

HRMS (ESI+) $m / z$ calculated for $\mathrm{C}_{23} \mathrm{H}_{30} \mathrm{BNO}_{2}{ }^{+}\left(\mathrm{M}^{+}\right)$363.2369, found $m / z$ 363.2374.

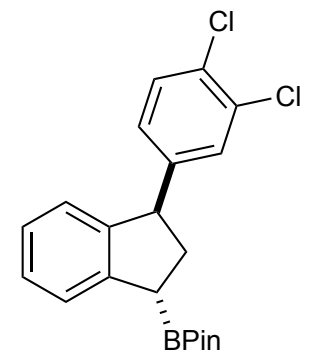

Trans-2-(3-(3,4-dichlorophenyl)-2,3-dihydro-1H-inden-1-yl)-

4,4,5,5-tetramethyl-1,3,2-dioxaborolane (2k). Note: product is prone to decomposition on silica. Attempts to isolate by flash column chromatography resulted in mixtures of the desired product with protodeborylated product. Prepared according to the general procedure using 0.08 $\mathrm{g}(0.020 \mathrm{mmol}, 20 \mathrm{~mol} \%$ loading $)$ of catalyst, $0.026 \mathrm{~g}(0.100 \mathrm{mmol})$ of substrate, $0.015 \mathrm{~g}(0.120$ 
mmol) of HBPin, and $2.0 \mathrm{~mL}$ of THF, the reaction was allowed to stir at $50^{\circ} \mathrm{C}$. After $24 \mathrm{~h}$, the reaction mixture was taken back into the glovebox and to volatiles were removed in vacuo. The residue was redissolved in pentane and the resulting solution was filtered through a plug of Celite to remove the cobalt. Purification by flash column chromatography (silica gel; gradient $0 \%$ to $5 \%$ to $10 \%$ ethyl acetate in hexanes) yielded a $2: 3$ mixture of the desired product and the protodeborylated indane. NMR yield of the desired product was determined using mesitylene as an internal standard as $0.023 \mathrm{mmol}\left(23 \%\right.$ yield). Due to overlapping peaks, the ${ }^{1} \mathrm{H}$ NMR was not assigned.

${ }^{13} \mathrm{C}\left\{{ }^{1} \mathrm{H}\right\}$ NMR $\left(126 \mathrm{MHz}, \mathrm{CDCl}_{3}, 23{ }^{\circ} \mathrm{C}\right): \delta 146.2$ (indanyl or aryl $\mathrm{C}$ ), 145.88 (indanyl or aryl $C$ ), 144.3 (indanyl or aryl C), 132.3 (aryl C), 130.7 (indanyl $C H$ ), 130.5 (indanyl $C H$ ), 129.9 (aryl $C$ ), 127.7 (indanyl or aryl $\mathrm{CH}$ ), 127.3 (indanyl or aryl $\mathrm{CH}$ ), 127.0 (or aryl indanyl $\mathrm{CH}$ ), 125.0 (indanyl or aryl $\mathrm{CH}$ ), 124.7 (indanyl or aryl $\mathrm{CH}$ ), 83.0 (BPin $\mathrm{C}$ ), 51.0 (3-indanyl CHAr), 38.2 (2-indanyl $\mathrm{CH}_{2}$ ), 29.4 (indenyl CHBPin), 24.9 (BPin $\mathrm{CH}_{3}$ ), 24.7 (BPin $\mathrm{CH}_{3}$ ).

${ }^{11}$ B NMR (96 MHz, $\left.\mathrm{CDCl}_{3}\right): \delta 32.04$.

HRMS (ESI+) $m / z$ calculated for $\mathrm{C}_{21} \mathrm{H}_{23} \mathrm{BCl}_{2} \mathrm{O}_{2}{ }^{+}\left(\mathrm{M}^{+}\right) 388.1168$, found $m / z$ 388.1197.<smiles>FC(F)(F)C1C[C@H](Br)c2ccccc21</smiles>

Trans-2-(3-(trifluoromethyl)-2,3-dihydro-1 $H$-inden-1-yl)-4,4,5,5tetramethyl-1,3,2-dioxaborolane (2l). Prepared according to the general procedure using $0.002 \mathrm{~g}(0.005 \mathrm{mmol}, 5 \mathrm{~mol} \%$ loading $)$ of catalyst, $0.018 \mathrm{~g}(0.100 \mathrm{mmol})$ of substrate, $0.013 \mathrm{~g}$ $(0.105 \mathrm{mmol})$ of HBPin, and $1.0 \mathrm{~mL}$ of toluene, the reaction was allowed to stir at $23^{\circ} \mathrm{C}$. After 24 $\mathrm{h}$, the reaction mixture was taken back into the glovebox and to volatiles were removed in vacuo. The residue was redissolved in pentane and the resulting solution was filtered through a 
plug of Celite to remove the cobalt. The volatiles were removed from the filtrate and the product was analyzed without further purification.

${ }^{1} \mathrm{H}$ NMR $\left(400 \mathrm{MHz}, \mathrm{CDCl}_{3}, 23{ }^{\circ} \mathrm{C}\right): \delta 7.37(\mathrm{~d}, J=7.6 \mathrm{~Hz}, 1 \mathrm{H}$, indanyl $\mathrm{CH}), 7.33(\mathrm{t}, J=5.9 \mathrm{~Hz}$, $1 \mathrm{H}$, indanyl $\mathrm{CH}), 7.26(\mathrm{t}, J=7.0 \mathrm{~Hz}$, indanyl $\mathrm{CH}), 7.18(\mathrm{~d}, J=7.3 \mathrm{~Hz}, 1 \mathrm{H}$, indanyl $\mathrm{CH}), 3.85(\mathrm{~m}$, 1H, 3-indanyl $\mathrm{CHCF}_{3}$ ), 2.93 (t, $\mathrm{J}=8.4 \mathrm{~Hz}, 1$-indanyl $\left.\mathrm{CHBPin}\right), 2.41\left(\mathrm{~m}, 2 \mathrm{H}, 2\right.$-indanyl $\mathrm{CH}_{2}$ ), 1.28 (s, 6H, BPin $\left.\mathrm{CH}_{3}\right), 1.25$ (s, 6H, BPin $\mathrm{CH}_{3}$ ).

${ }^{13} \mathrm{C}\left\{{ }^{1} \mathrm{H}\right\}$ NMR $\left(101 \mathrm{MHz}, \mathrm{CDCl}_{3}, 23{ }^{\circ} \mathrm{C}\right.$ ): $\delta 146.4$ (indanyl C),146.3 (indanyl C), 127.8 (q, $\mathrm{J}=$ $279.8 \mathrm{~Hz}, \mathrm{CF}_{3}$ ), 128.5 (indanyl $\mathrm{CH}$ ), 126.2 (indanyl $\mathrm{CH}$ ), 125.7 (indanyl $\mathrm{CH}$ ), 124.8 (indanyl $\mathrm{CH}$ ), 83.8 (BPin C), 49.1 (q, $J=28.0 \mathrm{~Hz}, 1$-indanyl $\mathrm{CHCF}_{3}$ ), 28.2 (2-indanyl $\mathrm{CH}_{2}$ ), $25.0\left(\mathrm{BPin} \mathrm{CH}_{3}\right.$ ), 24.7 (BPin $\mathrm{CH}_{3}$ ). The carbon attached to boron was not located.

${ }^{19} \mathrm{~F}$ NMR $\left(282 \mathrm{MHz}, \mathrm{CDCl}_{3}, 23{ }^{\circ} \mathrm{C}\right): \delta-71.81\left(\mathrm{~d}, J=9.75 \mathrm{~Hz}, \mathrm{C} F_{3}\right)$.

HRMS (ESI+) $m / z$ calculated for $\mathrm{C}_{16} \mathrm{H}_{20} \mathrm{BF}_{3} \mathrm{O}_{2}{ }^{+}[\mathrm{M}]^{+} 312.15084$, found $m / z$ 312.15088.

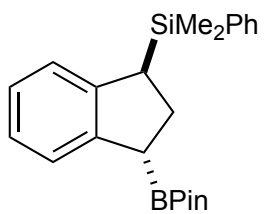

Trans-Dimethyl(phenyl)(3-(4,4,5,5-tetramethyl-1,3,2-dioxaborolan-

2-yl)-2,3-dihydro-1H-inden-1-yl)silane (2m). Prepared according to the general procedure using $0.002 \mathrm{~g}(0.005 \mathrm{mmol}, 5 \mathrm{~mol} \%$ loading $)$ of catalyst, $0.025 \mathrm{~g}(0.500 \mathrm{mmol})$ of substrate, $0.013 \mathrm{~g}(0.105 \mathrm{mmol})$ of HBPin, and $1.0 \mathrm{~mL}$ of toluene, the reaction was allowed to stir at $23{ }^{\circ} \mathrm{C}$. After $20 \mathrm{~h}$, the reaction mixture was quenched. Purification by flash column chromatography (silica gel; gradient $0 \%$ to $5 \%$ to $10 \%$ ethyl acetate in hexanes) yielded $0.028 \mathrm{~g}$ $(0.074 \mathrm{mmol}, 74 \%)$ of the product as a colorless oil.

${ }^{1} \mathrm{H}$ NMR $\left(400 \mathrm{MHz}, \mathrm{CDCl}_{3}, 23^{\circ} \mathrm{C}\right): \delta 7.43(\mathrm{~d}, J=7.6 \mathrm{~Hz}, 2 \mathrm{H}, \operatorname{ArCH}), 7.31-7.39(\mathrm{~m}, 3 \mathrm{H}, \operatorname{ArCH})$, $7.23(\mathrm{~d}, J=6.7 \mathrm{~Hz}, 1 \mathrm{H}, \operatorname{ArCH}), 7.03(\mathrm{~m}, 2 \mathrm{H}, \operatorname{ArCH}), 6.90(\mathrm{~J}=7.1 \mathrm{~Hz}, 1 \mathrm{H}, \operatorname{ArCH}), 2.79(\mathrm{~d}, \mathrm{~J}=9.7$ $\mathrm{Hz}, 1 \mathrm{H}, 3$-indanyl $\mathrm{CHSiMe} 2 \mathrm{Ph}), 2.48$ (m, 1H, 1-indanyl CHBPin), 2.39 (q, $J=11.2 \mathrm{~Hz}, 1 \mathrm{H}, 2-$ S46 
indanyl $\mathrm{CH}_{2}$ ), $2.23\left(\mathrm{~m}, 1 \mathrm{H}, 2\right.$-indanyl $\left.\mathrm{CH}_{2}\right), 1.26\left(\mathrm{~s}, 6 \mathrm{H}, \mathrm{BPin} \mathrm{CH}_{3}\right), 1.25\left(\mathrm{~s}, 6 \mathrm{H}, \mathrm{BPin} \mathrm{CH}_{3}\right), 0.30$ (s, 3H, $\left.\mathrm{SiCH}_{3}\right), 0.26\left(\mathrm{~s}, 3 \mathrm{H}, \mathrm{SiCH}_{3}\right)$.

${ }^{13} \mathrm{C}\left\{{ }^{1} \mathrm{H}\right\}$ NMR $\left(101 \mathrm{MHz}, \mathrm{CDCl}_{3}, 23^{\circ} \mathrm{C}\right): \delta 146.3$ (phenyl or indanyl $C$ ), 144.3 (phenyl or indanyl C), 138.4 (phenyl or indanyl $C$ ), 134.1 (phenyl o- or $m-C H$ ), 129.1 (p-phenyl $\mathrm{CH}$ ), 127.8 (o- or $m$ phenyl $\mathrm{CH}$ ), 125.5 (indanyl $\mathrm{CH}$ ), 124.9 (indanyl $\mathrm{CH}$ ), 124.5 (indanyl $\mathrm{CH}$ ), 123.7 (indanyl $\mathrm{CH}$ ), 83.4 (BPin C), 34.8 (3-indanyl $\mathrm{CHSiMe}_{2} \mathrm{Ph}$ ), 30.2 (2-indanyl $\mathrm{CH}_{2}$ ), 29.3 (1-indanyl $\mathrm{CHBPin}$ ), 25.0 (BPin $\left.\mathrm{CH}_{3}\right)$, $24.9\left(\mathrm{BPin} \mathrm{CH}_{3}\right),-4.05\left(\mathrm{SiCH}_{3}\right),-4.13\left(\mathrm{SiCH}_{3}\right)$.

${ }^{11}$ B NMR (96 MHz, $\left.\mathrm{CDCl}_{3}\right): \delta 33.25$.

HRMS (ESI+) $m / z$ calculated for $\mathrm{C}_{23} \mathrm{H}_{31} \mathrm{BO}_{2} \mathrm{Si}^{+}\left(\mathrm{M}^{+}\right)$378.2186, found $m / z$ 378.2222.

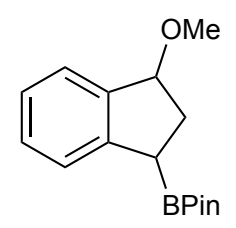

1:1 cis:trans
2-(3-methoxy-2,3-dihydro-1H-inden-1-yl)-4,4,5,5-tetramethyl-1,3,2-

dioxaborolane (2n). Note: product is prone to decomposition. Attempts to isolate in air by flash column chromatography resulted in mixtures of the desired product with protodeborylated product and unidentified decomposition products. Isolation was accomplished under inert atmosphere. Prepared according to the general procedure using $0.002 \mathrm{~g}(0.005 \mathrm{mmol}, 5 \mathrm{~mol} \%$ loading) of catalyst, $0.015 \mathrm{~g}(0.100 \mathrm{mmol})$ of substrate, $0.013 \mathrm{~g}(0.105 \mathrm{mmol})$ of HBPin, and 1.0 $\mathrm{mL}$ of toluene, the reaction was allowed to stir at $23^{\circ} \mathrm{C}$. After $20 \mathrm{~h}$, the reaction mixture was taken back into the glovebox and to volatiles were removed in vacuo. The residue was redissolved in pentane and the resulting solution was filtered through a plug of Celite to remove the cobalt. The volatiles were removed from the filtrate and the product was analyzed without further purification. The product was isolated as a $1: 1$ mixture of the trans and cis diastereomers. Other formed products were identified as 1-indanol and 2-(2,3-dihydro-1 $\mathrm{H}$-inden1-yl)-4,4,5,5-tetramethyl-1,3,2-dioxaborolane resulting from ether cleavage and S47 
protodeborylation, respectively, and confirmed by comparison of the ${ }^{13} \mathrm{C}$ NMR peaks against literature values. NMR yield of the desired product was determined using mesitylene as an internal standard as $0.030 \mathrm{mmol}\left(30 \%\right.$ yield). Due to overlapping peaks, the ${ }^{1} \mathrm{H}$ NMR was not assigned.

Cis and trans: ${ }^{13} \mathrm{C}\left\{{ }^{1} \mathrm{H}\right\} \operatorname{NMR}\left(101 \mathrm{MHz}, \mathrm{C}_{6} \mathrm{D}_{6}, 23{ }^{\circ} \mathrm{C}\right.$ ): $\delta 145.8$ (indenyl $C$ ), 144.2 (indenyl $C$ ), 144.1 (indenyl $C$ ), 143.2(indenyl $C$ ), 128.7 (indenyl $\mathrm{CH}$ ), 128.2 (indenyl $\mathrm{CH}$ ), 127.9 (indenyl $\mathrm{CH}$ ), 125.96 (indenyl $\mathrm{CH}$ ), 125.8 (indenyl $\mathrm{CH}$ ), 125.5 (indenyl $\mathrm{CH}$ ), 125.2 (indenyl $\mathrm{CH}$ ), 125.0 (indenyl CH), 87.6 (trans 3-indanyl CHOMe), 84.9 (cis 3-indanyl CHOMe), 83.4 (BPin C), 83.3 (BPin C), 56.2 (-OMe), $55.7(-\mathrm{OMe}), 35.1$ (trans 2-indanyl $\mathrm{CH}_{2}$ ), 33.2 (cis 2-indanyl $\mathrm{CH}_{2}$ ), 24.87 (BPin $M e$ ), 24.80 (BPin Me), 24.76 (BPin Me), 24.72 (BPin Me). The carbon attached to BPin was not located.

${ }^{11} \mathrm{~B}$ NMR $\left(96 \mathrm{MHz}, \mathrm{CDCl}_{3}\right): \delta 33.54$.

HRMS (ESI+) $m / z$ calculated for $\mathrm{C}_{16} \mathrm{H}_{23} \mathrm{BO}_{3}{ }^{+}\left(\mathrm{M}^{+}\right)$274.1740, found $\mathrm{m} / \mathrm{z} 274.1840$.

1-indanol: ${ }^{13} \mathrm{C}\left\{{ }^{1} \mathrm{H}\right\}$ NMR $\left(101 \mathrm{MHz}, \mathrm{C}_{6} \mathrm{D}_{6}\right): \delta 145.5,144.4,128.5,126.0,124.8,124.7,78.7,35.0,30.2$. Values matched with those reported. ${ }^{46}$

2-(2,3-dihydro-1 $H$-inden-1-yl)-4,4,5,5-tetramethyl-1,3,2-dioxaborolane: ${ }^{13} \mathrm{C}\left\{{ }^{1} \mathrm{H}\right\} \quad \mathrm{NMR}$ (101 $\mathrm{MHz}$, $\left.\mathrm{C}_{6} \mathrm{D}_{6}\right): \delta 144.5,143.9,126.8,126.5,125.1,125.0,83.2,33.6,28.2,24.9,24.8$. Values matched with those reported. ${ }^{5}$

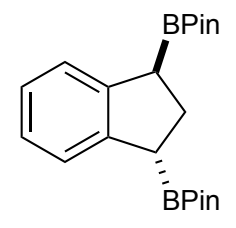

Trans-1,3-bis(4,4,5,5-tetramethyl-1,3,2-dioxaborolan-2-yl)-2,3dihydro-1 H-indene (20). Note: product is prone to protodeborylation on silica gel. Attempts to isolate by flash column chromatography resulted in isolation of monoboronate ester. Prepared according to the general procedure with the following modifications. Using $0.010 \mathrm{~g}(0.025 \mathrm{mmol}$, S48 
$5 \mathrm{~mol} \%$ loading $)$ of catalyst, $0.121 \mathrm{~g}(0.500 \mathrm{mmol})$ of 2-(1H-inden-3-yl)-4,4,5,5-tetramethyl-1,3,2dioxaborolane, $0.067 \mathrm{~g}(0.525 \mathrm{mmol})$ of HBPin, and $10 \mathrm{~mL}$ of THF, the reaction was placed in a heating block set at $50^{\circ} \mathrm{C}$. After $20 \mathrm{~h}$, the reaction vessel was cooled to $23^{\circ} \mathrm{C}$ then brought into the glove box. The reaction mixture was concentrated in vacuo. The residue was washed with pentane $(5 \mathrm{~mL})$ and again concentrated in vacuo. The crude residue was brought out of the glove box, exposed to air, then diluted with hexanes $(30 \mathrm{~mL})$. To the resulting solution was added $1.0 \mathrm{M} \mathrm{HCl}$ in water $(20 \mathrm{~mL})$ and the biphasic mixture was transferred to a separatory funnel. The layers were separated, and the aqueous layer was extracted with hexanes $(2 \times 30$ $\mathrm{mL})$. The organic layers were combined and washed with $1.0 \mathrm{M} \mathrm{HCl}$ in water $(20 \mathrm{~mL})$, water $(20$ $\mathrm{mL})$, and brine $(20 \mathrm{~mL})$. The organics were dried over $\mathrm{MgSO}_{4}$, filtered and concentrated in vacuo. Recrystallization of the resulting residue from concentrated hexanes solution at $-35{ }^{\circ} \mathrm{C}$ yielded $0.167 \mathrm{~g}(0.450 \mathrm{mmol}, 90 \%$ yield $)$ of the product as colorless crystals.

${ }^{1} \mathrm{H}$ NMR $\left(500 \mathrm{MHz}, \mathrm{CDCl}_{3}, 23^{\circ} \mathrm{C}\right): \delta 7.23$ (apparent dd, $J=3.2,5.1 \mathrm{~Hz}, 2 \mathrm{H}$, indanyl $\mathrm{CH}$ ), 7.05 (apparent dd, $J=3.3,5.5 \mathrm{~Hz}, 2 \mathrm{H}$, indanyl $\mathrm{CH}$ ), 2.80 (t, $J=7.8 \mathrm{~Hz}, 2 \mathrm{H}$, indanyl CHBPin), 2.28 (t, $J=7.9 \mathrm{~Hz}, 2 \mathrm{H}, 2$-indanyl $\mathrm{CH}$ ), 1.21 (apparent d, $J=2.7 \mathrm{~Hz}, 24 \mathrm{H}$, BPin $\mathrm{CH}_{3}$ ).

${ }^{13} \mathrm{C}\left\{{ }^{1} \mathrm{H}\right\}$ NMR (126 MHz, $\mathrm{CDCl}_{3}, 23^{\circ} \mathrm{C}$ ): $\delta 145.2$ (indanyl C), 125.5 (indanyl $\mathrm{CH}$ ), 124.2 (indanyl $\mathrm{CH}$ ), 83.3 (BPin $\mathrm{C}$ ), 30.5 (2-indanyl $\mathrm{CH}_{2}$ ), 30.3 (indenyl $\mathrm{CHBPin}$ ), 24.9 (BPin $\mathrm{CH}_{3}$ ), 24.8 (BPin $\mathrm{CH}_{3}$ ).

${ }^{11} \mathrm{~B}$ NMR $\left(96 \mathrm{MHz}, \mathrm{CDCl}_{3}\right): \delta 33.32$.

HRMS (ESI+) $m / z$ calculated for $\mathrm{C}_{21} \mathrm{H}_{32} \mathrm{~B}_{2} \mathrm{O}_{4}{ }^{+}\left(\mathrm{M}^{+}\right) 370.2487$, found $m / z$ 370.2543.<smiles>CC(C)(C)[N+]1([O-])CC([Pb])c2ccccc21</smiles>

Trans-5,5-dimethyl-2(3-(4,4,5,5-tetramethyl-1,3,2-dioxaborolan-2,yl)2,3-dihydro-1 H-inden-1-yl)-1,3,2-dioxaborinane (2p). Note: product is prone to S49 
protodeborylation on silica gel. Attempts to isolate by flash column chromatography resulted in multiple deborylated products. Therefore, the product was isolated under an inert atmosphere. Prepared according to the general procedure with the following modifications. Using $0.002 \mathrm{~g}$ (0.005 mmol, $5 \mathrm{~mol} \%$ loading) of catalyst, $0.023 \mathrm{~g}(0.100 \mathrm{mmol})$ of $2-(1 /$-inden-3-yl)-5,5dimethyl-1,3,2-dioxaborolane, $0.013 \mathrm{~g}(0.105 \mathrm{mmol})$ of HBPin, and $2 \mathrm{~mL}$ of toluene. The reaction was allowed to stir at $23^{\circ} \mathrm{C}$ for $20 \mathrm{~h}$, after which the reaction mixture was concentrated in vacuo. The crude residue was then diluted with pentane $(5 \mathrm{~mL})$, and the reaction mixture was filtered through celite on a fritted glass filter. The filtrate was concentrated in vacuo and isolated as a mixture of products identified as $\mathbf{2 p}, \mathbf{2 0}$, as well as 1,3-bis(5,5-dimethyl-1,3,2dioxaborinan-2-yl)-2,3-dihydro- $1 H$-indene. The NMR yield of $2 p$ was determined using mesitylene as an internal standard to yield $0.033 \mathrm{mmol}(33 \%)$ of $2 \mathrm{p}$. Due to overlapping peaks, the ${ }^{1} \mathrm{H}$ NMR was not assigned.

${ }^{13} \mathrm{C}\left\{{ }^{1} \mathrm{H}\right\}$ NMR $\left(126 \mathrm{MHz}, \mathrm{C}_{6} \mathrm{D}_{6}, 23{ }^{\circ} \mathrm{C}\right.$ ): $\delta 146.7$ (indanyl $C$ ), 144.4 (indanyl $C$ ), 126.4 (indanyl $\mathrm{CH}$ ), 125.8 (indanyl $\mathrm{CH}$ ), 124.9 (indanyl $\mathrm{CH}$ ), 124.6 (indanyl $\mathrm{CH}$ ), 82.4 (BPin $\mathrm{C}$ ), 72.0 (BNeop OCH$\left.{ }_{2}\right), 33.68$ (2-indanyl $\left.\mathrm{CH}_{2}\right), 31.4(\mathrm{BNeop} C), 24.9\left(\mathrm{BPin} \mathrm{CH}_{3}\right), 24.7\left(\mathrm{BPin} \mathrm{CH}_{3}\right), 21.6(\mathrm{BNeop}$ $\left.\mathrm{CH}_{3}\right)$.

${ }^{11}$ B NMR $\left(96 \mathrm{MHz}, \mathrm{C}_{6} \mathrm{D}_{6}\right): \delta 29.72$.

HRMS (ESI) $\mathrm{m} / \mathrm{z}$ calculated for $\mathrm{C}_{20} \mathrm{H}_{29} \mathrm{~B}_{2} \mathrm{O}_{4}^{-}\left([\mathrm{M}-\mathrm{H}]^{-}\right) 355.2257$, found $\mathrm{m} / \mathrm{z} 355.2283$.

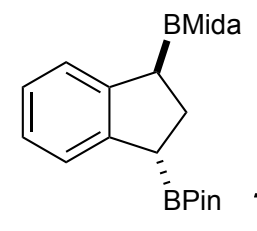

Trans-6-methyl-2-(3-(4,4,5,5-tetramethyl)-1,3,2-dioxaborolan-2-yl)2,3-dihydro-1 $H$-inden-1-yl)-1,3,6,2-dioxazaborocane-4,8-dione (2q). Note: product is prone to protodeborylation of BPin group on silica gel. Attempts to isolate by flash column S50 
chromatography resulted in isolation of monoboronate ester. Prepared according to the general procedure with the following modifications. Using $0.004 \mathrm{~g}(0.010 \mathrm{mmol}, 10 \mathrm{~mol} \%$ loading $)$ of catalyst, $0.027 \mathrm{~g}(0.100 \mathrm{mmol})$ of 2-(1H-inden-3-yl)- $N$-methyl-1,3,6,2-dioxazaborocane-4,8dione, $0.014 \mathrm{~g}(0.110 \mathrm{mmol})$ of HBPin, and $2 \mathrm{~mL}$ of THF, the reaction was placed in a heating block set to $50{ }^{\circ} \mathrm{C}$. After $20 \mathrm{~h}$, the reaction vessel was cooled to $23{ }^{\circ} \mathrm{C}$ then brought into the glove box. The reaction mixture was concentrated in vacuo. The crude residue was then diluted with pentane $(20 \mathrm{~mL})$, and the reaction mixture was filtered through celite on a fritted glass filter. The filtrate was concentrated in vacuo and the product isolated as a yellow solid to yield $0.029 \mathrm{~g}$ $(0.073 \mathrm{mmol}, 73 \%)$. The product was brought out of the box, exposed to air and analyzed immediately by NMR. The isolated product was kept in a glovebox for storage.

${ }^{1} \mathrm{H}$ NMR $\left(500 \mathrm{MHz}, \mathrm{CDCl}_{3}, 23^{\circ} \mathrm{C}\right): \delta 7.30(\mathrm{~m}, 1 \mathrm{H}$, indanyl $\mathrm{CH}), 7.23(\mathrm{~m}, 1 \mathrm{H}$, indanyl $\mathrm{CH}), 7.04$ (apparent dd, $J=3.3,5.5 \mathrm{~Hz}, 2 \mathrm{H}$, indanyl $\mathrm{CH}), 3.84-4.09\left(\mathrm{~m}, 2 \mathrm{H}\right.$, Mida $\left.-\mathrm{O}_{2} \mathrm{CCH}_{2}\right)$, 3.43-3.72 (m, 2H, Mida $-\mathrm{O}_{2} \mathrm{CCH}_{2}$ ), 2.72-2.79 (overlapping m, 2H, CHBPin and CHBMida), 2.75 (s, 3H, Mida $\left.\mathrm{CH}_{3}\right), 2.34\left(\mathrm{~m}, 1 \mathrm{H}, 2\right.$-indanyl $\left.\mathrm{CH}_{2}\right), 1.94\left(\mathrm{~m}, 1 \mathrm{H}, 2\right.$-indanyl $\left.\mathrm{CH}_{2}\right), 1.23\left(\mathrm{~s}, 6 \mathrm{H}, \mathrm{BPin} \mathrm{CH}_{3}\right), 1.22(\mathrm{~s}$, $6 \mathrm{H}$, BPin $\mathrm{CH}_{3}$ ).

${ }^{13} \mathrm{C}\left\{{ }^{1} \mathrm{H}\right\}$ NMR (126 MHz, $\mathrm{CDCl}_{3}, 23{ }^{\circ} \mathrm{C}$ ): $\delta 167.9$ (Mida $-\mathrm{O}_{2} \mathrm{CCH}_{2}$ ), 167.7 (Mida $-\mathrm{O}_{2} \mathrm{CCH}_{2}$ ), 145.6 (indanyl C), 144.87 (indanyl $C$ ), 125.9 (indanyl $\mathrm{CH}$ ), 125.8 (indanyl $\mathrm{CH}$ ), 124.8 (indanyl $\mathrm{CH}$ ), 124.6 (indanyl $\mathrm{CH}$ ), 83.6 (BPin $\mathrm{C}$ ), 63.0 (Mida $-\mathrm{O}_{2} \mathrm{CCH}_{2}$ ), 62.8 (Mida $-\mathrm{O}_{2} \mathrm{CCH}_{2}$ ), 46.0 (Mida $\mathrm{NCH}_{3}$ ), 33.5 ( $\mathrm{CHBMida),} 29.8$ ( $\mathrm{CHBPin}$ ), 29.4 (2-indanyl $\mathrm{CH}_{2}$ ), 25.0 (BPin $\mathrm{CH}_{3}$ ), 24.8 (BPin $\mathrm{CH}_{3}$ ).

${ }^{11}$ B NMR (96 MHz, $\left.\mathrm{CDCl}_{3}\right): \delta 33.66$.

HRMS (ESI+) $m / z$ calculated for $\mathrm{C}_{20} \mathrm{H}_{27} \mathrm{~B}_{2} \mathrm{NO}_{6}{ }^{+}\left(\mathrm{M}^{+}\right)$399.2025, found $\mathrm{m} / \mathrm{z}$ 399.21071. 


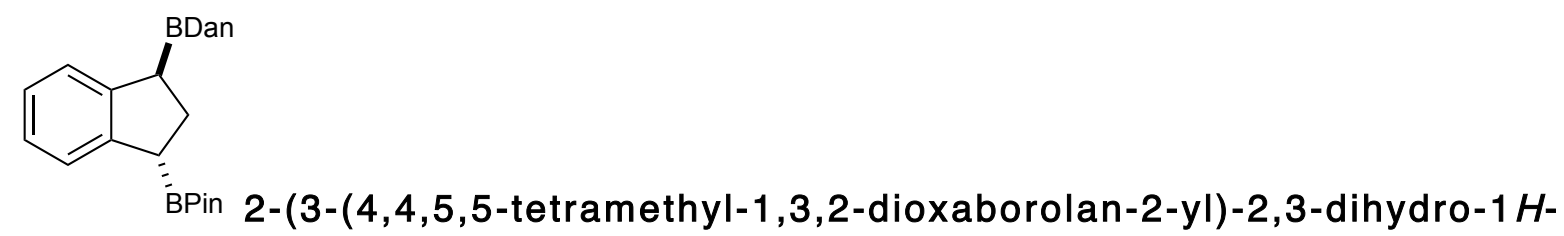

inden-1-yl)-2,3-dihydro-1 H-naphtho[1,8-de][1,3,2]diazaborinine (2r). Note: product is prone to protodeborylation of BPin group on silica gel. Attempts to isolate by flash column chromatography resulted in isolation of monoboronate ester. Prepared according to the general procedure with the following modifications. Using $0.010 \mathrm{~g}(0.025 \mathrm{mmol}, 5 \mathrm{~mol} \%$ loading $)$ of catalyst, $\quad 0.141 \quad \mathrm{~g} \quad(0.500 \mathrm{mmol}) \quad$ of $\quad 2-(1 \mathrm{H}$-inden-3-yl)-2,3-dihydro-1H-naphtho[1,8de][1,3,2]diazaborinine, $0.067 \mathrm{~g}(0.525 \mathrm{mmol})$ of HBPin, and $10 \mathrm{~mL}$ of THF, the reaction was placed in a heating block set to $50^{\circ} \mathrm{C}$. After $20 \mathrm{~h}$, the reaction vessel was cooled to $23^{\circ} \mathrm{C}$ then brought into the glove box. The reaction mixture was concentrated in vacuo. The crude residue was then diluted with pentane $(20 \mathrm{~mL})$, and the reaction mixture was filtered through celite on a fritted glass filter. The filtrate was concentrated in vacuo and the product isolated as a peachcolored fluffy solid to yield $0.129 \mathrm{~g}(0.315 \mathrm{mmol}, 63 \%)$ as a $1: 1$ mixture of regioisomers. Exposure of the product to air results in selective protodeborylation of the BPin group from the 1,1-product. Due to the limited stability, NMR analysis was performed on the crude material under an $\mathrm{N}_{2}$ atmosphere in $\mathrm{C}_{6} \mathrm{D}_{6}$.

${ }^{1} \mathrm{H}$ NMR $\left(500 \mathrm{MHz}, \mathrm{C}_{6} \mathrm{D}_{6}, 23^{\circ} \mathrm{C}\right): \delta 7.65$ (obsc. $\mathrm{d}, J=8.0 \mathrm{~Hz}, 1 \mathrm{H}$, indanyl $\left.\mathrm{CH}\right), 7.17-7.22(\mathrm{~m}$, $3 \mathrm{H}$, indanyl $\mathrm{CH}$ or Dan $\mathrm{CH}), 6.95-7.11(\mathrm{~m}, 6 \mathrm{H}$, indanyl $\mathrm{CH}$ or Dan $\mathrm{CH}), 5.81(\mathrm{dd}, \mathrm{J}=1.4,7.0 \mathrm{~Hz}$, 2H, Dan CH), 5.07 (bs, 2H, Dan NH), 2.91 (m, 1H, CHBPin), 2.75 (m, 1H, CHBDan), 2.56 (obsc. m, 1H, 2- $\left.\mathrm{CH}_{2}\right), 2.07$ (ddd, J = 7.0, 8.7, $\left.12.1 \mathrm{~Hz}, 1 \mathrm{H}, 2-\mathrm{CH}_{2}\right), 1.06\left(\mathrm{~s}, 6 \mathrm{H}, \mathrm{BPin} \mathrm{CH}_{3}\right), 1.05(\mathrm{~s}, 6 \mathrm{H}$, BPin $\mathrm{CH}_{3}$ ). 


\section{2-(1-(4,4,5,5-tetramethyl-1,3,2-dioxaborolan-2-yl)-2,3-dihydro-1 $H$ -}

inden-1-yl)2-3-dihydro-1 $H$-naphtho[1,8-de][1,3,2]diazaborinine.

${ }^{1} \mathrm{H}$ NMR $\left(500 \mathrm{MHz}, \mathrm{C}_{6} \mathrm{D}_{6}, 23{ }^{\circ} \mathrm{C}\right): \delta 7.65$ (obsc. d, $J=8.0 \mathrm{~Hz}, 1 \mathrm{H}$, indanyl $\left.\mathrm{CH}\right), 7.17-7.22(\mathrm{~m}$, $3 \mathrm{H}$, indanyl $\mathrm{CH}$ or Dan $\mathrm{CH}), 6.95-7.11(\mathrm{~m}, 6 \mathrm{H}$, indanyl $\mathrm{CH}$ or Dan $\mathrm{CH}$ ), $5.90(\mathrm{dd}, \mathrm{J}=0.9,7.2 \mathrm{~Hz}$, 2H, Dan $\mathrm{CH}$ ), 5.83 (bs, 2H, Dan $\mathrm{NH}$ ), $2.86\left(\mathrm{~m}, 2 \mathrm{H}, 3\right.$-indanyl $\left.\mathrm{CH}_{2}\right), 2.62\left(\mathrm{~m}, 1 \mathrm{H}\right.$, 2-indanyl $\mathrm{CH}_{2}$ ), $2.27\left(\mathrm{~m}, 1 \mathrm{H}, 2\right.$-indanyl $\left.\mathrm{CH}_{2}\right), 0.97\left(\mathrm{~s}, 12 \mathrm{H}, \mathrm{BPin} \mathrm{CH}_{3}\right)$.

Mixture of 1,1 and 1,3 products:

${ }^{13} \mathrm{C}\left\{{ }^{1} \mathrm{H}\right\}$ NMR $\left(126 \mathrm{MHz}, \mathrm{C}_{6} \mathrm{D}_{6}, 23{ }^{\circ} \mathrm{C}\right): \delta 147.1,146.3,146.0,143.8,141.48,141.47,137.03$, $137.00,126.9,126.4,126.3,125.7,125.03,125.01,124.9,124.6,120.5,120.4,118.2,118.1$, 106.4, 106.3, 83.6, 83.4, 33.3, 33.2, 32.6, 24.9, 24.8, 24.7, 24.62.

${ }^{11} \mathrm{~B}$ NMR $\left(96 \mathrm{MHz}, \mathrm{CDCl}_{3}\right): \delta 32.17$.

HRMS (ESI+) $m / z$ calculated for $\mathrm{C}_{25} \mathrm{H}_{29} \mathrm{~B}_{2} \mathrm{~N}_{2} \mathrm{O}_{2}{ }^{+}\left(\mathrm{M}^{+}\right) 410.2337$, found $m / z 410.2368$.<smiles>CC(C)(C)C1Cc2ccccc2C1c1ccccc1</smiles>

Trans-4,4,5,5-tetramethyl-2-(2-butyl-2,3-dihydro-1 $H$-inden-1-yl)-

1,3,2-dioxaborolane (2s). Prepared according to the general procedure using $0.004 \mathrm{~g}(0.01$ $\mathrm{mmol}, 10 \mathrm{~mol} \%$ loading $)$ of catalyst, $0.017 \mathrm{~g}(0.10 \mathrm{mmol})$ of substrate, $0.014 \mathrm{~g}(0.11 \mathrm{mmol})$ of HBPin, and $0.10 \mathrm{~mL}$ of toluene, the reaction was allowed to stir at $50^{\circ} \mathrm{C}$. After $24 \mathrm{~h}$, the reaction mixture was quenched. Purification by flash column chromatography (silica gel; gradient $0 \%$ to $5 \%$ to $10 \%$ ethyl acetate in hexanes) yielded $0.03 \mathrm{~g}(0.1 \mathrm{mmol}$, quantitative $)$ of the product as a clear oil.

${ }^{1} \mathrm{H}$ NMR $\left(500 \mathrm{MHz}, \mathrm{CDCl}_{3}, 23^{\circ} \mathrm{C}\right): \delta 7.17(\mathrm{~m}, 2 \mathrm{H}$, indanyl $\mathrm{CH}), 7.09(\mathrm{~m}, 2 \mathrm{H}$, indanyl $\mathrm{CH}), 3.08$ (m, 1H, 3-indanyl $\mathrm{CH}_{2}$ ), 2.57 (overlapping $\mathrm{m}, 2 \mathrm{H}, 3$-indanyl $\mathrm{CH}_{2}$ and 2-indanyl $\mathrm{CH}$ ), $2.40(\mathrm{~d}, \mathrm{~J}=$ 
$9.1 \mathrm{~Hz}, 1 \mathrm{H}, 1$-indanyl $\mathrm{CH}), 1.55\left(\mathrm{~m}, 2 \mathrm{H}, \mathrm{Bu} \mathrm{CH} \mathrm{CH}_{2}, 1.37\left(\mathrm{~m}, 4 \mathrm{H}, \mathrm{Bu} \mathrm{CH} \mathrm{CH}_{2}, 1.28\left(\mathrm{~s}, 6 \mathrm{H}, \mathrm{BPin} \mathrm{CH}_{3}\right)\right.\right.$, $1.27\left(\mathrm{~s}, 6 \mathrm{H}, \mathrm{BPin} \mathrm{CH}_{3}\right), 0.92(\mathrm{t}, J=6.7 \mathrm{~Hz}, 3 \mathrm{H}, \mathrm{Bu} \mathrm{CH})_{3}$.

$\left\{{ }^{1} \mathrm{H}\right\}^{13} \mathrm{C}$ NMR $\left(126 \mathrm{MHz}, \mathrm{CDCl}_{3}, 23^{\circ} \mathrm{C}\right.$ ): $\delta 145.0$ (indanyl C), 144.2 (indanyl C), 126.1 (indanyl $\mathrm{CH}$ ), 125.7 (indanyl $\mathrm{CH}$ ), 124.3 (indanyl $\mathrm{CH}$ ), 124.2 (indanyl $\mathrm{CH}$ ), 83.4 (BPin $\mathrm{C}$ ), 43.2 (2-indanyl $\mathrm{CHBu}$ ), 40.1 (3-indanyl $\mathrm{CH}_{2}$ ), 36.1 (butyl $\mathrm{CH}_{2}$ ), 31.1 (butyl $\mathrm{CH}_{2}$ ), 29.9 (butyl $\mathrm{CH}_{2}$ ), 25.0 (BPin $\mathrm{CH}_{3}$ ), 24.7 (BPin $\mathrm{CH}_{3}$ ), 23.1 (butyl $\mathrm{CH}_{2}$ ), 14.3 (butyl $\mathrm{CH}_{3}$ ). The carbon attached to boron was not located.

${ }^{11}$ B NMR $\left(96 \mathrm{MHz}, \mathrm{CDCl}_{3}, 23^{\circ} \mathrm{C}\right): \delta 33.7$.

HRMS (ESI+) $m / z$ calculated for $\mathrm{C}_{19} \mathrm{H}_{29} \mathrm{BO}_{2}[\mathrm{M}]^{+} 300.22606$, found $\mathrm{m} / \mathrm{z} 300.22720$.

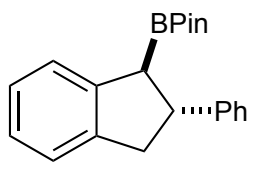

Trans-4,4,5,5-tetramethyl-2-(2-phenyl-2,3-dihydro-1 $H$-inden-1-yl)-

1,3,2-dioxaborolane (2t). Prepared according to the general procedure using $0.004 \mathrm{~g}(0.01$ $\mathrm{mmol}, 10 \mathrm{~mol} \%$ loading $)$ of catalyst, $0.019 \mathrm{~g}(0.10 \mathrm{mmol})$ of substrate, $0.014 \mathrm{~g}(0.11 \mathrm{mmol})$ of $\mathrm{HBPin}$, and $0.10 \mathrm{~mL}$ of toluene, the reaction was allowed to stir at $50^{\circ} \mathrm{C}$. After $24 \mathrm{~h}$, the reaction mixture was quenched. Purification by flash column chromatography (silica gel; gradient $0 \%$ to $5 \%$ to $10 \%$ ethyl acetate in hexanes) yielded $0.027 \mathrm{~g}(0.084 \mathrm{mmol}, 84 \%)$ of the product as an off-white solid.

${ }^{1} \mathrm{H}$ NMR $\left(500 \mathrm{MHz}, \mathrm{CDCl}_{3}, 23^{\circ} \mathrm{C}\right): \delta 7.36(\mathrm{~d}, J=7.4 \mathrm{~Hz}, 2 \mathrm{H}$, indanyl $\mathrm{CH}), 7.30$ (appt. t, $J=7.6$ $\mathrm{Hz}, 2 \mathrm{H}$, indanyl $\mathrm{CH}$ ), $3.83(\mathrm{q}, J=9.4 \mathrm{~Hz}, 1 \mathrm{H}, 2$-indanyl $\mathrm{CH}$ ), $3.36(\mathrm{dd}, J=8.3,15.6 \mathrm{~Hz}, 1 \mathrm{H}, 3$ indanyl $\left.\mathrm{CH}_{2}\right), 3.14\left(\mathrm{~m}, 1 \mathrm{H}, 3\right.$-indanyl $\left.\mathrm{CH}_{2}\right), 2.91(\mathrm{~d}, \mathrm{~J}=9.7 \mathrm{~Hz}, 1 \mathrm{H}, 1$-indanyl $\mathrm{CH}), 1.25(\mathrm{~s}, 6 \mathrm{H}$, BPin $\mathrm{CH}_{3}$ ), 1.23 (s, 6H, BPin $\mathrm{CH}_{3}$ ).

$\left\{{ }^{1} \mathrm{H}\right\}^{13} \mathrm{C}$ NMR $\left(126 \mathrm{MHz}, \mathrm{CDCl}_{3}, 23^{\circ} \mathrm{C}\right.$ ): $\delta 145.5$ (indanyl C), 144.3 (indanyl $C$ ), 143.4 (indanyl C), 128.4 (phenyl $\mathrm{CH}$ ), 127.4 (phenyl $\mathrm{CH}$ ), 126.6 (indanyl or phenyl $\mathrm{CH}$ ), 126.2 (indanyl or phenyl $\mathrm{CH}$ ), 126.1 (indanyl $\mathrm{CH}$ ), 124.4 (indanyl $\mathrm{CH}$ ), 124.1 (indanyl $\mathrm{CH}$ ), 83.7 (BPin $\mathrm{C}$ ), 48.2 (2S54 
indanyl $\mathrm{CHPh}$ ), 41.6 (3-indanyl $\mathrm{CH}_{2}$ ), $25.2\left(\mathrm{BPin} \mathrm{CH}_{3}\right), 24.6\left(\mathrm{BPin} \mathrm{CH}_{3}\right.$ ). The carbon attached to boron was not located.

${ }^{11} \mathrm{~B}$ NMR $\left(96 \mathrm{MHz}, \mathrm{CDCl}_{3}, 23^{\circ} \mathrm{C}\right): \delta 33.4$.

HRMS (ESI+) $m / z$ calculated for $\mathrm{C}_{19} \mathrm{H}_{29} \mathrm{BO}_{2}[\mathrm{M}]^{+}$300.22606, found $\mathrm{m} / \mathrm{z} 320.19524$.<smiles></smiles>

2,2'-(trans-2,3-dihydro-1 $H$-indene-1,2-diyl)bis (4,4,5,5-tetramethyl-

1,3,2-dioxaborolane) (xx). Prepared according to the general procedure using $0.004 \mathrm{~g}(0.01$ $\mathrm{mmol}, 10 \mathrm{~mol} \%$ loading $)$ of catalyst, $0.024 \mathrm{~g}(0.10 \mathrm{mmol})$ of substrate, $0.014 \mathrm{~g}(0.11 \mathrm{mmol})$ of HBPin, and $0.10 \mathrm{~mL}$ of $\mathrm{THF}$, the reaction was allowed to stir at $50^{\circ} \mathrm{C}$. After $24 \mathrm{~h}$, the reaction mixture was quenched. Purification by flash column chromatography (silica gel; gradient $0 \%$ to $5 \%$ to $10 \%$ ethyl acetate in hexanes) yielded $0.035 \mathrm{~g}(0.095 \mathrm{mmol}, 95 \%)$ of the product as a clear oil.

${ }^{1} \mathrm{H}$ NMR $\left(500 \mathrm{MHz}, \mathrm{CDCl}_{3}, 23^{\circ} \mathrm{C}\right): \delta 7.21(\mathrm{~d}, J=6.2 \mathrm{~Hz}, 2 \mathrm{H}$, indanyl $\mathrm{CH}), 7.16$ (appt. $\mathrm{d}, J=6.3$ $\mathrm{Hz}, 1 \mathrm{H}$, indanyl $\mathrm{CH}), 7.05(\mathrm{~m}, 2 \mathrm{H}$, indanyl $\mathrm{CH}), 2.99\left(\mathrm{dd}, J=9.0,15.5 \mathrm{~Hz}, 1 \mathrm{H}, 3\right.$-indanyl $\mathrm{CH}_{2}$ ), $2.89(\mathrm{~m}, 1 \mathrm{H}, 1$-indanyl $\mathrm{CH}), 2.72(\mathrm{~d}, J=12.0 \mathrm{~Hz}, 1 \mathrm{H}, \mathrm{Bu} \mathrm{CH}), 1.90(\mathrm{~m}) ,1.23(\mathrm{~m}, 24 \mathrm{H}$, BPin $\left.\mathrm{CH}_{3}\right)$.

$\left\{{ }^{1} \mathrm{H}\right\}^{13} \mathrm{C}$ NMR $\left(126 \mathrm{MHz}, \mathrm{CDCl}_{3}, 23^{\circ} \mathrm{C}\right.$ ): $\delta 145.8$ (indanyl C), 145.3 (indanyl $C$ ), 125.9 (indanyl $\mathrm{CH}$ ), 125.5 (indanyl $\mathrm{CH}$ ), 124.1 (indanyl $\mathrm{CH}$ ), 124.0 (indanyl $\mathrm{CH}$ ), 83.4 (BPin $\mathrm{C}$ ), 83.2 (BPin $\mathrm{C}$ ), 35.6 (3-indanyl $\left.\mathrm{CH}_{2}\right)$, $25.0\left(\mathrm{BPin} \mathrm{CH}_{3}\right), 24.89\left(\mathrm{BPin} \mathrm{CH}_{3}\right), 24.85\left(\mathrm{BPin} \mathrm{CH}_{3}\right), 24.7\left(\mathrm{BPin} \mathrm{CH}_{3}\right)$. The carbons attached to boron were not located.

${ }^{11}$ B NMR $\left(96 \mathrm{MHz}, \mathrm{CDCl}_{3}, 23^{\circ} \mathrm{C}\right): \delta 34.0$.

HRMS (ESI+) $m / z$ calculated for $\mathrm{C}_{19} \mathrm{H}_{29} \mathrm{BO}_{2}[\mathrm{M}]^{+} 370.24867$, found $\mathrm{m} / \mathrm{z} 370.25023$. 
Table S2. Alkene substrates inactive toward hydroboration with [Co]-1.

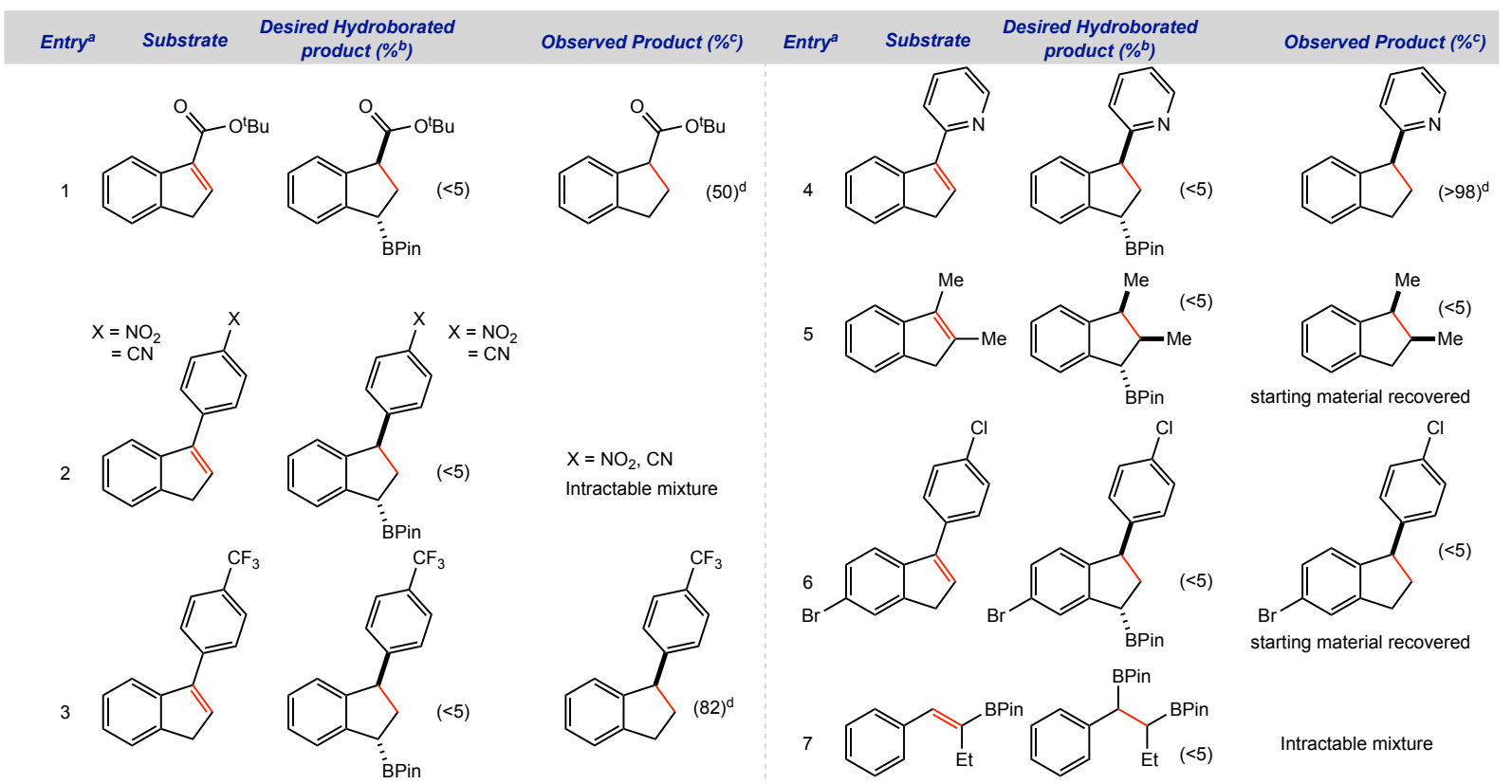

${ }^{\text {a }}$ Reaction run on $0.1 \mathrm{mmol}$ scale at $0.1 \mathrm{M}$ in PhMe with $5 \mathrm{~mol} \%$ [Co]-1 at $25^{\circ} \mathrm{C}$ for $20 \mathrm{~h}$. ${ }^{\mathrm{b}}$ Yield as determined by uncalibrated relative integrals of hydroborated product to cyclooctane signals measureed by gas chromatographic analysis of the unpurified mixture. ${ }^{\mathrm{C}} \mathrm{NMR}$ yield as determined by integration of the ${ }^{1} \mathrm{H}$ NMR peaks against mesitylene standard. ${ }^{\mathrm{d}}$ Alkane product confirmed by ${ }^{1} \mathrm{H}$ and ${ }^{13} \mathrm{C}$ NMR.

\section{Synthetic Applications of Indanyl Boronate Esters.}

\section{Oxidation of boronate esters}

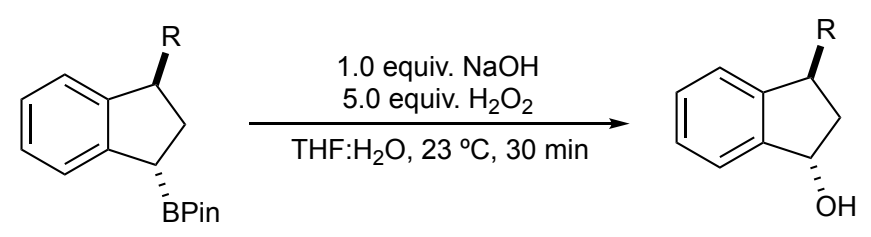

Preparation adapted from Ritter and coworkers. ${ }^{47}$ In air, the boronate ester was dissolved in THF (0.2 M solution). To the solution, $\mathrm{NaOH}$ (aqueous, 1.0 equiv.) and $\mathrm{H}_{2} \mathrm{O}_{2}\left(30 \%\right.$ in $\mathrm{H}_{2} \mathrm{O}, 5.0$ equiv) were added. The reaction was allowed to stir at $23^{\circ} \mathrm{C}$ for $30 \mathrm{~min}$. The reaction was then diluted with $\mathrm{Et}_{2} \mathrm{O}(5 \mathrm{~mL})$. The aqueous layer was separated and extracted with $\mathrm{Et}_{2} \mathrm{O}(1 \times 5 \mathrm{~mL})$. The organic layers were then combined and washed with saturated $\mathrm{NaHCO}_{3}$, followed by brine, and dried over $\mathrm{Na}_{2} \mathrm{SO}_{4}$. Following filtration and removal of the volatiles in vacuo, the crude residue was then purified by chromatography on silica gel, eluting with $20 \% \mathrm{v} / \mathrm{v}$ $\mathrm{Et}_{2} \mathrm{OAc} /$ hexanes, to give the alcohol. 


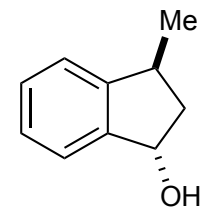

Trans-3-methyl-2,3-dihydro-1H-inden-1-ol (3a). Prepared according to the procedure above using $0.026 \mathrm{~g}(0.10 \mathrm{mmol})$ of $2 \mathrm{a}, 0.10 \mathrm{~mL} \mathrm{NaOH}$ (1 equiv., $0.10 \mathrm{mmol}, 1 \mathrm{M}$ aqueous), $0.057 \mathrm{~g} \mathrm{H}_{2} \mathrm{O}_{2}$ (5 equiv, $0.50 \mathrm{mmol}$, 30\% in $\mathrm{H}_{2} \mathrm{O}$ ), and $0.50 \mathrm{~mL}$ THF. Yield $0.014 \mathrm{~g}$ $(0.094 \mathrm{mmol}, 95 \%)$ as a clear oil. ${ }^{1} \mathrm{H}$ and ${ }^{13} \mathrm{C}$ NMR data agree with values reported. ${ }^{48}$

${ }^{1} \mathrm{H}$ NMR $\left(400 \mathrm{MHz}, \mathrm{CDCl}_{3}, 23{ }^{\circ} \mathrm{C}\right): \delta 7.4-7.1(\mathrm{~m}, 4 \mathrm{H}, \mathrm{ArH}), 5.24(\mathrm{dd}, J=3.1,6.8 \mathrm{~Hz}, 1 \mathrm{H}$, $\mathrm{CHOH}$ ), 3.45 (sext., $J=6.8 \mathrm{~Hz}, 1 \mathrm{H}, \mathrm{CHCH}_{3}$ ), 2.25 (ddd, $J=3.1,6.8,13.7 \mathrm{~Hz}, 1 \mathrm{H}, \mathrm{CH}_{2}$ ), 1.96 (dt, $\left.J=6.8,13.7 \mathrm{~Hz}, 1 \mathrm{H}, \mathrm{CH}_{2}\right), 1.9(\mathrm{br}, 1 \mathrm{H}, \mathrm{OH}), 1.28\left(\mathrm{~d}, J=6.8 \mathrm{~Hz}, 3 \mathrm{H}, \mathrm{CH}_{3}\right)$.

${ }^{13} \mathrm{C}\left\{{ }^{1} \mathrm{H}\right\}$ NMR $\left(101 \mathrm{MHz}, \mathrm{CDCl}_{3}, 23{ }^{\circ} \mathrm{C}\right): \delta 148.8$ (indanyl 3a-C), 144.5 (indanyl 7a-C), 128.9 (indanyl 7- $\mathrm{CH}$ ), 127.0 (indanyl 5- $\mathrm{CH}$ ), 124.6 (indanyl 6- $\mathrm{CH}$ ), 123.9 (indanyl 4- $\mathrm{CH}$ ), 75.4 (1$\mathrm{CHOH}), 44.9\left(2-\mathrm{CH}_{2}\right), 36.9\left(3-\mathrm{CHCH}_{3}\right), 20.4\left(\mathrm{CH}_{3}\right)$.<smiles>O[C@H]1C[C@H](c2ccccc2)c2ccccc21</smiles>

Trans-3-phenyl-2,3-dihydro-1H-inden-1-ol (3e). Prepared according to the procedure above using $0.032 \mathrm{~g}(0.10 \mathrm{mmol})$ of $2 \mathrm{e}, 0.100 \mathrm{~mL} \mathrm{NaOH}$ (1 equiv., $0.10 \mathrm{mmol}, 1 \mathrm{M}$ aqueous), $0.057 \mathrm{~g} \mathrm{H}_{2} \mathrm{O}_{2}$ (5 equiv., $0.50 \mathrm{mmol}, 30 \%$ in $\mathrm{H}_{2} \mathrm{O}$ ), and $0.50 \mathrm{~mL}$ THF. Yield $0.020 \mathrm{~g}$ $(0.097 \mathrm{mmol}, 97 \%)$ as a clear oil. COSY and NOESY ${ }^{1} \mathrm{H}$ NMR data are consistent with retention of stereoconfiguration resulting in the trans alcohol. The trans alcohol is not reported in the literature.

${ }^{1} \mathrm{H}$ NMR $\left(400 \mathrm{MHz}, \mathrm{CDCl}_{3}, 23{ }^{\circ} \mathrm{C}\right): \delta 7.48(\mathrm{~m}, 1 \mathrm{H}$, indanyl $\mathrm{CH}), 7.33-7.24$ (overlapping $\mathrm{m}, 5 \mathrm{H}$, phenyl or indanyl $\mathrm{CH}), 7.14(\mathrm{~m}, 2 \mathrm{H}, \mathrm{o}$ - or $m$-phenyl $\mathrm{CH}), 7.04(\mathrm{dd}, \mathrm{J}=2.0,6.2 \mathrm{~Hz}, 1 \mathrm{H}, p$-phenyl CH), $5.37(\mathrm{dd}, J=2.8,6.1 \mathrm{~Hz}, 1 \mathrm{H}, \mathrm{CHOH}), 4.63(\mathrm{t}, J=7.4 \mathrm{~Hz}, 1 \mathrm{H}, \mathrm{PhCH}), 2.54$ (ddd, J = 3.0, 7.8, 13.7 Hz, 1H, CH ), 2.39 (ddd, J=6.4, 7.1, 13.6 Hz, 1H, $\mathrm{CH}_{2}$ ), 1.77 (br. s, $1 \mathrm{H}, \mathrm{OH}$ ). 
${ }^{13} \mathrm{C}\left\{{ }^{1} \mathrm{H}\right\}$ NMR $\left(101 \mathrm{MHz}, \mathrm{CDCl}_{3}, 23{ }^{\circ} \mathrm{C}\right.$ ): $\delta 146.9$ (indanyl 3a-C), 145.1 (phenyl C), 144.8 (indanyl 7a-C), 129.2 (phenyl or indanyl $\mathrm{CH}$ ), 128.7 (o- or $m-\mathrm{Ph} \mathrm{CH}$ ), 128.0 (o- or $m-\mathrm{Ph} \mathrm{CH}$ ), 127.5 (phenyl or indanyl $\mathrm{CH}$ ), 126.6 (phenyl or indanyl $\mathrm{CH}$ ), 125.6 (p-phenyl $\mathrm{CH}$ ), 124.6 (indanyl $\mathrm{CH}), 75.5$ (C-1, $\mathrm{CHOH}), 49.0$ (C-3, $\mathrm{CHPh}), 46.5$ (C-2, indanyl $\mathrm{CH}_{2}$ ).

HRMS (ESI+) $m / z$ calculated for $\mathrm{C}_{15} \mathrm{H}_{14} \mathrm{O}^{+}\left(\mathrm{M}^{+}\right) 210.1045$, found $m / z 210.1051$.

\section{Vinylation of boronate esters}

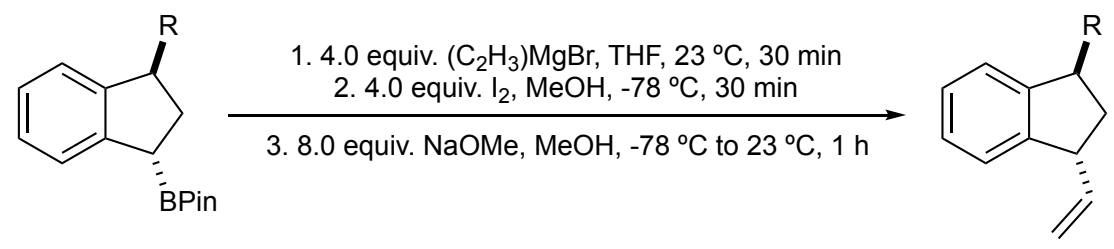

Preparation adapted from Aggarwal and coworkers. ${ }^{49}$ Performed under argon on a Schlenk line: An oven-dried $20 \mathrm{~mL}$ glass vial equipped with a screw-cap with a Teflon septum insert was charged with the boronate ester, anhydrous THF $(0.1 \mathrm{M})$, and a magnetic stir bar. A solution of vinylmagnesium bromide (1.0 M in THF, 4 equiv.) was added dropwise at $23{ }^{\circ} \mathrm{C}$ to the stirring solution. The reaction was allowed to stir at this temperature for $30 \mathrm{~min}$ then cooled down to -78 ${ }^{\circ} \mathrm{C}$. A solution of iodine (4 equiv) in anhydrous $\mathrm{MeOH}(4 \mathrm{~mL})$ was added dropwise to the reaction mixture via cannula, followed 30 min later by a solution of $\mathrm{NaOMe}$ (8 equiv) in $5 \mathrm{~mL}$ anhydrous $\mathrm{MeOH}$. The reaction was then allowed to warm to room temperature and stirred for an additional hour, diluted with pentane $(40 \mathrm{~mL})$ and washed with $20 \%$ aqueous $\mathrm{NaS}_{2} \mathrm{O}_{3}$ solution $(5 \mathrm{~mL})$ and water $(10 \mathrm{~mL})$. The aqueous layer was separated and extracted with pentane $(2 \times 20 \mathrm{~mL})$. The 
organic layers were then combined, washed with brine $(10 \mathrm{~mL})$, and dried over $\mathrm{MgSO}_{4}$. Following filtration and removal of the volatiles in vacuo, the crude residue was then purified by chromatography on silica gel, eluting with hexanes to give the vinylated product.<smiles>C=C[C@H]1CC([N+](=O)[O-])c2ccccc21</smiles>

Trans-1-methyl-3-vinyl-2,3-1 $H$-indene (4a). Prepared according to the procedure above using $0.100 \mathrm{~g}(0.387 \mathrm{mmol})$ of $2 \mathrm{a}, 1.55 \mathrm{~mL}(1 \mathrm{M}$ in THF, $1.55 \mathrm{mmol})$ vinylmagnesium bromide solution, iodine (0.393 g, $1.55 \mathrm{mmol})$, and $\mathrm{NaOMe}(0.167 \mathrm{~g}, 3.10$ $\mathrm{mmol})$. Yield $0.028 \mathrm{~g}(0.177 \mathrm{mmol}, 45 \%)$ as a clear oil. The product is not reported in the literature.

${ }^{1} \mathrm{H}$ NMR $\left(400 \mathrm{MHz}, \mathrm{CDCl}_{3}, 23{ }^{\circ} \mathrm{C}\right): \delta 7.22-7.13(\mathrm{~m}, 4 \mathrm{H}$, indenyl $\mathrm{CH}), 5.86(\mathrm{ddd}, J=17.1,10.0$, $8.0 \mathrm{~Hz}, 1 \mathrm{H}$, vinyl $\mathrm{CH}$ ), $5.08\left(\mathrm{ddd}, J=17.0,1.8,1.1 \mathrm{~Hz}, 1 \mathrm{H}\right.$, vinyl $\left.\mathrm{CH}_{2}\right), 5.02(\mathrm{ddd}, J=10.0,1.8$, $0.8 \mathrm{~Hz}, 1 \mathrm{H}$, vinyl $\mathrm{CH}_{2}$ ), $3.83(\mathrm{q}, J=7.5 \mathrm{~Hz}, 1 \mathrm{H}$, ), $3.28(\mathrm{dq}, J=14.3,7.1 \mathrm{~Hz}, 1 \mathrm{H}$, ), $2.13(\mathrm{ddd}, J=$ 12.7, 7.7, $6.0 \mathrm{~Hz}, 1 \mathrm{H}$, ), 1.94 (ddd, $J=12.7,8.0,5.6 \mathrm{~Hz}, 1 \mathrm{H}$, ), $1.26\left(\mathrm{~d}, J=2.0 \mathrm{~Hz}, 3 \mathrm{H}, \mathrm{CH}_{3}\right.$ ).

${ }^{13} \mathrm{C}\left\{{ }^{1} \mathrm{H}\right\}$ NMR $\left(101 \mathrm{MHz}, \mathrm{CDCl}_{3}, 23^{\circ} \mathrm{C}\right): \delta 148.8$ (phenyl or indanyl $C$ ), 145.1 (phenyl or indanyl C), 141.5 (vinyl $\mathrm{CH}$ ), 127.0 (indanyl $\mathrm{CH}$ ), 126.5 (indanyl $\mathrm{CH}$ ), 124.7 (indanyl $\mathrm{CH}$ ), 123.7 (indanyl $\mathrm{CH}$ ), 114.2 (vinyl $\mathrm{CH}_{2}$ ), 48.0 (indanyl $\mathrm{CH}$ (vinyl)), 41.4 (indanyl $\mathrm{CH}_{2}$ ), 38.1 (indanyl $\mathrm{CHCH}_{3}$ ), 20.7 $(\mathrm{CH})$.

HRMS (ESI+) $m / z$ calculated for $\mathrm{C}_{15} \mathrm{H}_{14} \mathrm{O}^{+}\left(\mathrm{M}^{+}\right)$158.1096, found $m / z$ 158.1014.<smiles>C=C[C@H]1CC(c2ccccc2)c2ccccc21</smiles>

Trans-1-methyl-3-vinyl-2,3-1H-indene (4e). Prepared according to the procedure above using $0.100 \mathrm{~g}(0.312 \mathrm{mmol})$ of $2 \mathrm{e}, 1.25 \mathrm{~mL}(1 \mathrm{M}$ in THF, $1.25 \mathrm{mmol})$ S59 
vinylmagnesium bromide solution, iodine $(0.317 \mathrm{~g}, 1.25 \mathrm{mmol})$, and NaOMe $(0.135 \mathrm{~g}, 2.50$ $\mathrm{mmol})$. Yield $0.021 \mathrm{~g}(0.095 \mathrm{mmol}, 31 \%)$ as a clear oil. The product is not reported in the literature.

${ }^{1} \mathrm{H}$ NMR (400 MHz, $\mathrm{CDCl}_{3}, 23{ }^{\circ} \mathrm{C}$ ): $\delta$ 7.19-7.32 (overlapping $\mathrm{m}, 6 \mathrm{H}$, phenyl and indanyl $\mathrm{CH}$ ), $7.15(\mathrm{dd}, \mathrm{J}=1.4,8.1 \mathrm{~Hz}, 2 \mathrm{H}$, phenyl $\mathrm{CH}), 7.08(\mathrm{~m}, 1 \mathrm{H}$, phenyl or indanyl $\mathrm{CH}$ ), 5.95 (ddd, $J=$ 17.7, 10.0, 7.9 Hz, $1 \mathrm{H}$, vinyl $\mathrm{CH}$ ), $5.14-5.08\left(\mathrm{~m}, 2 \mathrm{H}\right.$, vinyl $\left.\mathrm{CH}_{2}\right), 4.47(\mathrm{dd}, J=7.8,6.3 \mathrm{~Hz}, 1 \mathrm{H}$, indanyl $\mathrm{CHPh}$ ), $3.95(\mathrm{dd}, J=7.6,14.2 \mathrm{~Hz}, 1 \mathrm{H}$, indanyl $\mathrm{CH}($ vinyl)), $2.47-2.35(\mathrm{~m}, 2 \mathrm{H}$, indanyl $\mathrm{CH}_{2}$ ).

${ }^{13} \mathrm{C}\left\{{ }^{1} \mathrm{H}\right\}$ NMR $\left(101 \mathrm{MHz}, \mathrm{CDCl}_{3}, 23^{\circ} \mathrm{C}\right): \delta 146.4$ (phenyl or indanyl $C$ ), 145.8 (phenyl or indanyl C), 145.5 (phenyl or indanyl $C$ ), 141.0 (vinyl $\mathrm{CH}$ ), 128.6 (phenyl $\mathrm{CH}$ ), 128.0 (phenyl $\mathrm{CH}$ ), 127.2 (phenyl or indanyl $\mathrm{CH}$ ), 127.1 (phenyl or indanyl $\mathrm{CH}$ ), 126.4 (phenyl or indanyl $\mathrm{CH}$ ), 125.4 (phenyl or indanyl $\mathrm{CH}$ ), 124.8 (phenyl or indanyl $\mathrm{CH}$ ), 114.7 (vinyl $\mathrm{CH}_{2}$ ), 49.9 (indanyl $\mathrm{CHPh}$ ), 48.4 (indanyl $\mathrm{CH}\left(\right.$ vinyl)), 43.1 (indanyl $\mathrm{CH}_{2}$ ).

HRMS (ESI+) $m / z$ calculated for $\mathrm{C}_{15} \mathrm{H}_{14} \mathrm{O}^{+}\left(\mathrm{M}^{+}\right)$220.1252, found $m / z 220.1294$.

\section{Cross-Coupling of boronate esters}

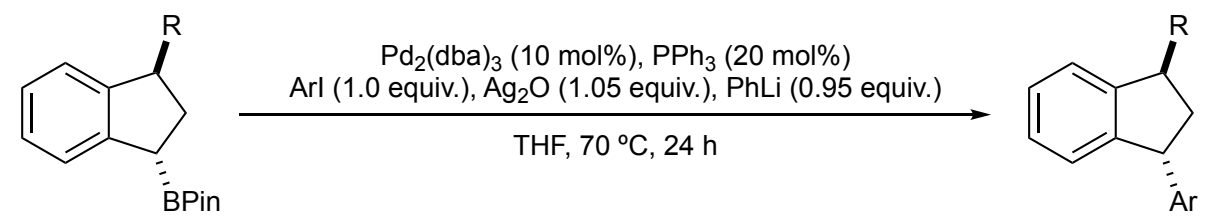

Preparation adapted from Crudden and coworkers. ${ }^{50}$ In an $\mathrm{N}_{2}$-atmosphere glovebox, a $20 \mathrm{~mL}$ vial was charged with boronate ester, $\mathrm{Arl}$ (0.680 equiv.), $\mathrm{Ag}_{2} \mathrm{O}$ (1.03 equiv.), $\mathrm{Pd}_{2}(\mathrm{dba})_{3}(8.1$ mol\%), $\mathrm{PPh}_{3}$ (0.673 equiv.), THF and a stir bar. The vial was then sealed, brought out of the 
glovebox, and stirred at $70{ }^{\circ} \mathrm{C}$ for $24 \mathrm{~h}$. The desired product was isolated by column chromatography using hexanes/benzene as the eluent (gradient 20:1 to 10:1).

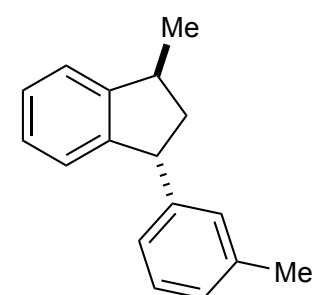

Trans-1-methyl-3-(m-tolyl)-2,3-dihydro-1H-indene (5a). Prepared according to the procedure above using $0.038 \mathrm{~g}(0.147 \mathrm{mmol})$ of $2 \mathrm{a}, 0.022 \mathrm{~g}(0.100 \mathrm{mmol})$ of 3 iodotoluene, $0.035 \mathrm{~g}(0.152 \mathrm{mmol}) \mathrm{Ag}_{2} \mathrm{O}, 3.66 \mathrm{mg}(0.004 \mathrm{mmol}) \mathrm{Pd}_{2}(\mathrm{dba})_{3}, 0.026 \mathrm{~g}(0.099$ mmol) $\mathrm{PPh}_{3}$, and $2 \mathrm{~mL}$ THF. Yield $0.025 \mathrm{~g}(0.112 \mathrm{mmol}, 76 \%)$ as a clear oil. The product is not reported in the literature.

${ }^{1} \mathrm{H}$ NMR $\left(400 \mathrm{MHz}, \mathrm{CDCl}_{3}, 23{ }^{\circ} \mathrm{C}\right): \delta 7.23(\mathrm{~m}, 2 \mathrm{H}$, indanyl or aryl $\mathrm{CH}), 7.16(\mathrm{~m}, 2 \mathrm{H}$, indanyl or aryl $\mathrm{CH}), 7.02(\mathrm{~m}, 2 \mathrm{H}$, indanyl or aryl $\mathrm{CH}), 6.96(\mathrm{~s}, 1 \mathrm{H}$, aryl $\mathrm{CH}), 6.92(\mathrm{~d}, J=7.7 \mathrm{~Hz}, 1 \mathrm{H}$, indanyl or aryl $\mathrm{CH}), 4.41(\mathrm{dd}, J=6.2,8.3 \mathrm{~Hz}, 1 \mathrm{H}$, indanyl $\mathrm{CHAr}), 3.41(\mathrm{~m}, 1 \mathrm{H}$, indanyl $\mathrm{CHMe}), 2.28-2.35$ (m, $1 \mathrm{H}$, indanyl $\left.\mathrm{CH}_{2}\right), 2.32\left(\mathrm{~s}, 3 \mathrm{H}\right.$, aryl $\left.\mathrm{CH}_{3}\right), 1.31\left(\mathrm{~d}, \mathrm{~J}=7.0 \mathrm{~Hz}, 3 \mathrm{H}\right.$, indanyl $\left.\mathrm{CHCH}_{3}\right)$.

${ }^{13} \mathrm{C}\left\{{ }^{1} \mathrm{H}\right\}$ NMR $\left(101 \mathrm{MHz}, \mathrm{CDCl}_{3}, 23^{\circ} \mathrm{C}\right): \delta 149.3$ (indanyl or aryl C), 146.2 (indanyl or aryl C), 145.8 (indanyl or aryl $C$ ), 138.1 (indanyl or aryl $C$ ), 128.7 (indanyl or aryl $\mathrm{CH}$ ), 128.4 (indanyl or aryl $\mathrm{CH}$ ), 127.1 (indanyl or aryl $\mathrm{CH}$ ), 126.9 (indanyl or aryl $\mathrm{CH}$ ), 126.7 (indanyl or aryl $\mathrm{CH}$ ), 125.3 (indanyl or aryl $\mathrm{CH}$ ), 125.1 (indanyl or aryl $\mathrm{CH}$ ), 123.6 (indanyl or aryl $\mathrm{CH}$ ), 49.7 (indanyl $\mathrm{CHAr}$ ), 44.8 (indanyl $\mathrm{CH}_{2}$ ), 38.3 (indanyl $\mathrm{CHMe}$ ), 21.6 (aryl $\mathrm{CH}_{3}$ ), 20.6 (indanyl $\mathrm{CHCH}_{3}$ ).

HRMS (ESI+) $m / z$ calculated for $\mathrm{C}_{17} \mathrm{H}_{18}{ }^{+}\left(\mathrm{M}^{+}\right)$222.1409, found $\mathrm{m} / \mathrm{z} 222.1399$. 


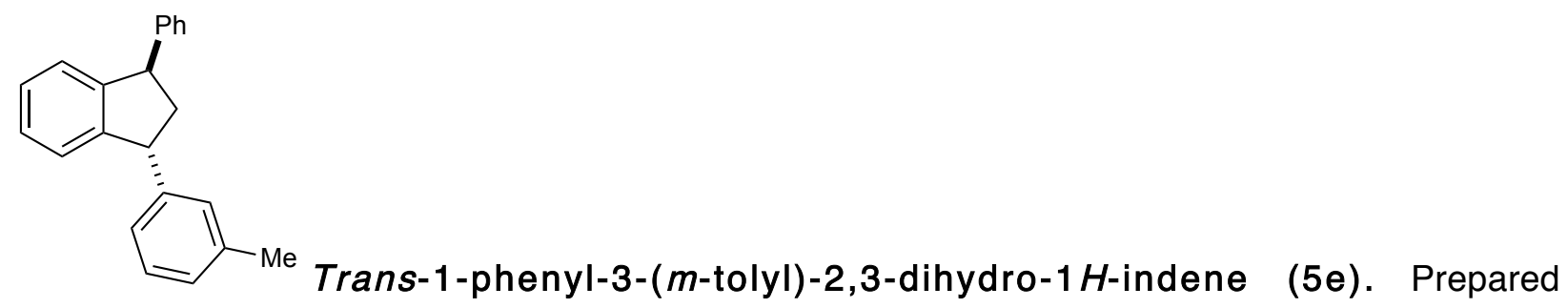
according to the procedure above using $0.047 \mathrm{~g}(0.147 \mathrm{mmol})$ of $2 \mathrm{e}, 0.022 \mathrm{~g}(0.100 \mathrm{mmol})$ of 3iodotoluene, $0.035 \mathrm{~g}(0.152 \mathrm{mmol}) \mathrm{Ag}_{2} \mathrm{O}, 3.66 \mathrm{mg}(0.004 \mathrm{mmol}) \mathrm{Pd}_{2}(\mathrm{dba})_{3}, 0.026 \mathrm{~g}(0.099$ mmol) $\mathrm{PPh}_{3}$, and $2 \mathrm{~mL}$ THF. Yield $0.040 \mathrm{~g}(0.141 \mathrm{mmol}, 96 \%)$ as a clear oil. The product is not reported in the literature.

${ }^{1} \mathrm{H}$ NMR $\left(400 \mathrm{MHz}, \mathrm{CDCl}_{3}, 23{ }^{\circ} \mathrm{C}\right): \delta$ 6.98-7.41 (m, 13H, indanyl, phenyl and aryl $\left.\mathrm{CH}\right), 4.59$ (appt. dt, $J=7.1,10.9 \mathrm{~Hz}, 2 \mathrm{H}, 1$ - and 3-indanyl $\mathrm{CH}$ ), 2.65 (t, $J=7.2 \mathrm{~Hz}, 2 \mathrm{H}, 2$-indanyl $\mathrm{CH}_{2}$ ), $2.37\left(\mathrm{~s}, 3 \mathrm{H}, \mathrm{CH}_{3}\right)$.

${ }^{13} \mathrm{C}\left\{{ }^{1} \mathrm{H}\right\}$ NMR $\left(101 \mathrm{MHz}, \mathrm{CDCl}_{3}, 23{ }^{\circ} \mathrm{C}\right.$ ): $\delta 146.9$ (aryl or indanyl $C$ ), 146.8 (aryl or indanyl $C$ ), 145.4 (aryl or indanyl C), 145.3 (aryl or indanyl C), 138.1 (aryl or indanyl C), 128.7 (aryl or indanyl $\mathrm{CH}$ ), 128.5 (aryl or indanyl $\mathrm{CH}$ ), 128.4 (o- or m-phenyl $\mathrm{CH}$ ), 127.9 (aryl or indanyl $\mathrm{CH}$ ), 127.15 (o- or $m$-phenyl $\mathrm{CH}$ ), 127.14 (aryl or indanyl $\mathrm{CH}$ ), 127.11 (aryl or indanyl $\mathrm{CH}$ ), 126.3 (aryl or indanyl $\mathrm{CH}$ ), 125.24 (aryl or indanyl $\mathrm{CH}$ ), 125.20 (aryl or indanyl $\mathrm{CH}$ ), 125.0 (aryl or indanyl $\mathrm{CH}$ ), 49.97 (1- or 3-indanyl $\mathrm{CH}$ ), 49.91 (1- or 3-indanyl $\mathrm{CH}$ ), 46.4 (2-indanyl $\mathrm{CH}_{2}$ ), 21.5 (aryl $\left.\mathrm{CH}_{3}\right)$.

HRMS (ESI+) $m / z$ calculated for $\mathrm{C}_{22} \mathrm{H}_{20}{ }^{+}\left(\mathrm{M}^{+}\right) 284.1565$, found $m / z 284.1601$.

\section{Formation of $\mathrm{BF}_{3} \mathrm{~K}$ salt}

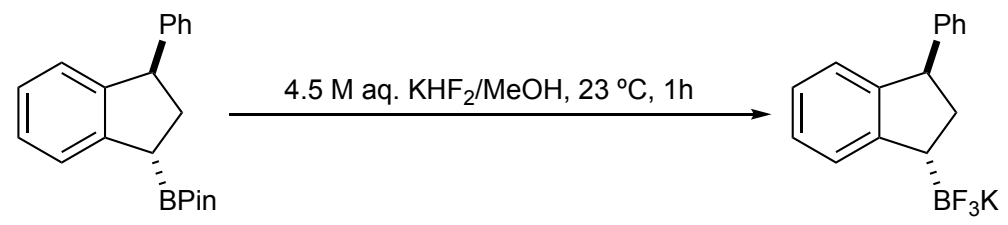


Potassium Trans-2-(3-phenyl-2,3-dihydro-1H-inden-1-yl)-trifluoroborate (6e). Preparation adapted from Aggarwal and coworkers. ${ }^{51}$ In air, the boronate ester $2 \mathrm{e}(0.058 \mathrm{~g}$, $0.181 \mathrm{mmol})$ was dissolved in methanol $\left(0.2 \mathrm{M}\right.$ solution). To the solution, $\mathrm{KHF}_{2}(0.064 \mathrm{~g}, 0.815$ mmol) in $\mathrm{H}_{2} \mathrm{O}(1 \mathrm{~mL})$ was added dropwise at room temperature. The reaction was allowed to stir for $30 \mathrm{~min}$. The volatiles were removed in vacuo, and the residue redissolved in $\mathrm{MeOH}$. Evaporation-dissolution cycles were repeated $\mathrm{x} 4$. The solid residue was then washed with acetone, the liquid phase decanted, and concentrated in vacuo to give the desired trifluoroborate as a white solid in $92 \%$ yield $(0.050 \mathrm{~g}, 0167 \mathrm{mmol})$.

${ }^{1} \mathrm{H}$ NMR $\left(400 \mathrm{MHz}, \mathrm{CD}_{3} \mathrm{CN}, 23{ }^{\circ} \mathrm{C}\right): \delta 7.15-7.29(\mathrm{~m}, 6 \mathrm{H}$, indanyl and phenyl $\mathrm{CH}), 7.01(\mathrm{t}, J=$ $7.4 \mathrm{~Hz}, 1 \mathrm{H}$, indanyl or phenyl $\mathrm{CH}), 6.89(\mathrm{t}, J=7.3 \mathrm{~Hz}, 1 \mathrm{H}$, indanyl or phenyl $\mathrm{CH}), 6.70(\mathrm{~d}, J=$ 7.4 Hz, $1 \mathrm{H}$, indanyl or phenyl $\mathrm{CH}$ ), $4.34(\mathrm{t}, J=8.5 \mathrm{~Hz}, 1 \mathrm{H}, 3$-indanyl $\mathrm{CHPh}), 2.45$ (t, $J=11.6 \mathrm{~Hz}$, 1H, 1-indanyl $\left.\mathrm{CHBF}_{3}\right), 2.17\left(\mathrm{~m}, 1 \mathrm{H}, 2\right.$-indanyl $\left.\mathrm{CH}_{2}\right), 2.00\left(\mathrm{~m}, 1 \mathrm{H}, 2\right.$-indanyl $\left.\mathrm{CH}_{2}\right)$.

${ }^{13} \mathrm{C}\left\{{ }^{1} \mathrm{H}\right\}$ NMR (101 MHz, $\mathrm{CD}_{3} \mathrm{CN}, 23{ }^{\circ} \mathrm{C}$ ): $\delta 148.8$ (phenyl or indanyl $\mathrm{C}$ ), 148.7 (phenyl or indanyl C), 147.7 (phenyl or indanyl C), 129.1 (phenyl CH), 129.0 (phenyl CH), 126.5 (phenyl or indanyl $\mathrm{CH}$ ), 126.4 (phenyl or indanyl $\mathrm{CH}$ ), 125.1 (phenyl or indanyl $\mathrm{CH}$ ), 124.5 (phenyl or indanyl $\mathrm{CH}$ ), 124.3 (phenyl or indanyl $\mathrm{CH}$ ), 52.3 (3-indanyl $\mathrm{CHPh}$ ), 40.8 (2-indanyl $\mathrm{CH}_{2}$ ), 37.9 (1indanyl $\left.\mathrm{CHBF}_{3}\right)$.

${ }^{11}$ B NMR $\left(96 \mathrm{MHz}, \mathrm{CD}_{3} \mathrm{CN}, 23^{\circ} \mathrm{C}\right): \delta 3.4$.

${ }^{19} \mathrm{~F}$ NMR $\left(282 \mathrm{MHz}, \mathrm{CDCl}_{3}, 23{ }^{\circ} \mathrm{C}\right): \delta-145.3$.

HRMS (ESI+) $\mathrm{m} / z$ calculated for $\mathrm{C}_{15} \mathrm{H}_{13} \mathrm{BF}_{3}\left(\mathrm{M}-\mathrm{K}^{+}\right)$261.1062, found $\mathrm{m} / \mathrm{z} 261.1121$.

\section{Kinetics.}

Experimental rate law determined using the method of variable time normalization analysis. 
In a nitrogen-filled glovebox, an NMR tube fitted with a J-Young adapter was charged with the specified amount of a $0.4 \mathrm{M}$ solution of 6-methoxy-3-methyl-1H-indene (1b) and mesitylene (3:1) and a $0.04 \mathrm{M}$ solution of [Co]-1 in $\mathrm{C}_{6} \mathrm{D}_{6}$. The tube was then sealed and brought out of the glovebox to take the initial time point. The J-Young tube was then taken back into the glovebox, placed in the coldwell and frozen. Pinacolborane (HBPin) was then added to the frozen tube. The tube was sealed, brought out of the glovebox, and allowed to warm to room temperature. The reaction was monitored by ${ }^{1} \mathrm{H}$ NMR at regular time points and concentration of alkene or product was determined through integration against mesitylene standard. The order in [Co]-1, alkene and HBPin was determined using the method of variable time normalization analysis developed by Burés. ${ }^{52,53}$

Table S3. Amounts of 6-methoxy-3-methyl-1H-indene (1 b), mesitylene, HBPin and [Co]-1 used in the rate law experiments.

\begin{tabular}{|c|c|c|c|c|}
\hline Run & $\begin{array}{c}\text { Amount of a } 0.4 \mathrm{M} \\
\text { solution of } 6 \text {-methoxy- } \\
\text { 3-methyl-1 } H \text {-indene } \\
\text { (1b) and mesitylene } \\
(3: 1) \text { in } \mathrm{C}_{6} \mathrm{D}_{6}\end{array}$ & $\begin{array}{c}\text { Amount of of } \\
\text { HBPin }\end{array}$ & $\begin{array}{c}\text { Amount of a } \\
0.04 \mathrm{M} \\
\text { solution of } \\
{[\mathrm{Co}]-1 \text { in } \mathrm{C}_{6} \mathrm{D}_{6}}\end{array}$ & $\begin{array}{c}\text { Amount of } \\
C_{6} D_{6}\end{array}$ \\
\hline 1 & $100 \mu \mathrm{L}$ & $6 \mu \mathrm{L}$ & $25 \mu \mathrm{L}$ & $269 \mu \mathrm{L}$ \\
\hline 2 & $100 \mu \mathrm{L}$ & $6 \mu \mathrm{L}$ & $12 \mu \mathrm{L}$ & $282 \mu \mathrm{L}$ \\
\hline 3 & $100 \mu \mathrm{L}$ & $6 \mu \mathrm{L}$ & $6 \mu \mathrm{L}$ & $288 \mu \mathrm{L}$ \\
\hline 4 & $50 \mu \mathrm{L}$ & $6 \mu \mathrm{L}$ & $25 \mu \mathrm{L}$ & $319 \mu \mathrm{L}$ \\
\hline 5 & $100 \mu \mathrm{L}$ & $12 \mu \mathrm{L}$ & $25 \mu \mathrm{L}$ & $263 \mu \mathrm{L}$ \\
\hline
\end{tabular}


a.

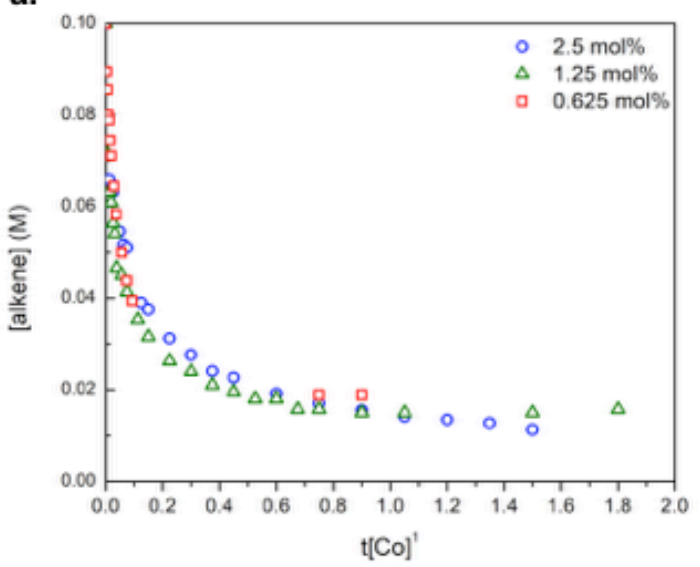

c.

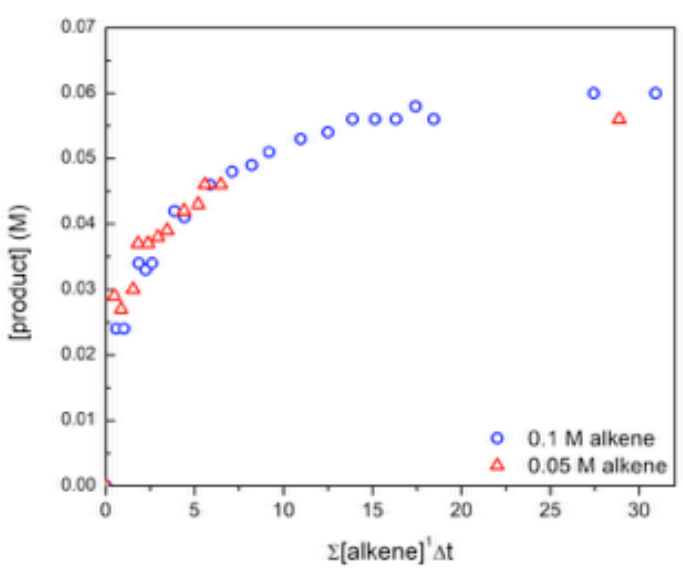

b.

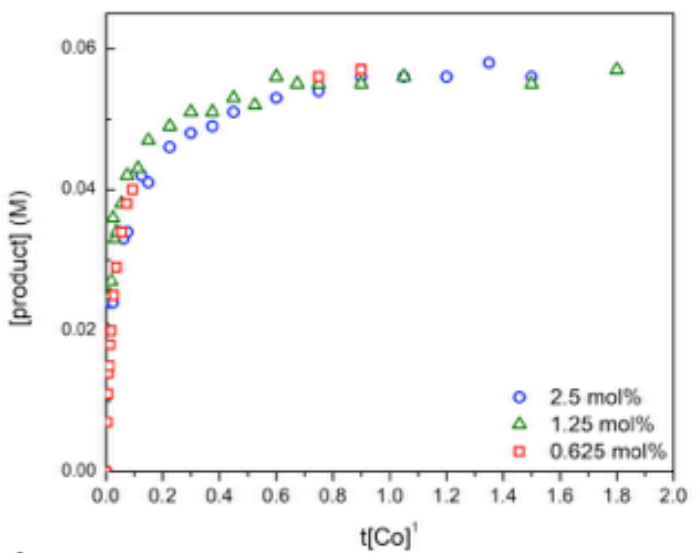

d.

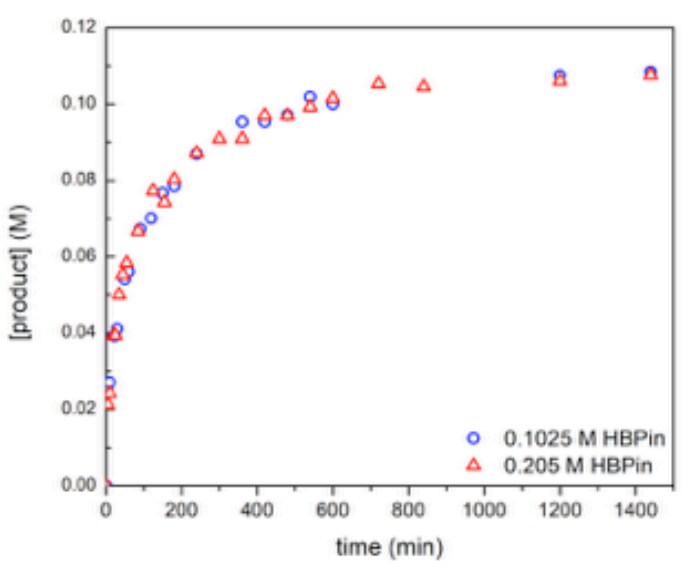

Figure S1. Plots of (a) normalized time scale analysis to determine order in catalyst, [indene] (M) vs. $\mathrm{t}[\mathrm{Co}]^{1}$, (b) normalized time scale analysis to determine order in catalyst, [product] (M) vs. $\mathrm{t}[\mathrm{Co}]^{1}$, (c) variable time normalization analysis to determine order in alkene, [product] (M) vs. $\Sigma\left[\right.$ alkene] $^{1} \Delta \mathrm{t}$, (d) full reaction progress to determine order in HBPin, [product] (M) vs time (min). 


\section{Deuterium Labeling Studies.}

Preparation of Pinacolborane- $d_{1}$. Pinacolborane- $d_{1}$ (DBPin) was prepared using a previously reported procedure ${ }^{54}$ The product was isolated via air-free vacuum distillation. The extent of the ${ }^{2} \mathrm{H}$ incorporation was determined to be $85 \%$ by the integration of the ${ }^{2} \mathrm{H}$ resonance against a known amount of $\mathrm{C}_{6} \mathrm{D}_{6}$.

${ }^{2} \mathrm{H}$ NMR (96 MHz, $\left.\mathrm{C}_{6} \mathrm{D}_{6}\right): \delta 4.45$ (broad).

Deuteroboration Experiments. Deuteroboration experiments were conducted according to the general procedure for cobalt-catalyzed hydroboration using DBPin ( $85 \%$ isotopic purity). Following completion of the reaction and isolation of the product, the material was analyzed by

${ }^{1} \mathrm{H}$ NMR, ${ }^{2} \mathrm{H}$ NMR $\left(\mathrm{C}_{6} \mathrm{H}_{6}\right.$ internal standard), quantitative $\left\{{ }^{1} \mathrm{H}\right\}^{13} \mathrm{C}$ NMR, and mass spectrometry to determine the isotopic incorporation of the product. 
NMR Spectra of Deuteroboration of Three Isomers of Methyl Indene.

Deuteroboration of 3-methyl-1H-indene (1a).

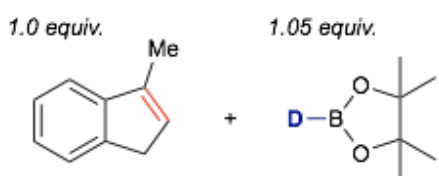

a. ${ }^{1 H}$ NMR of Natural abundance $2 a$.

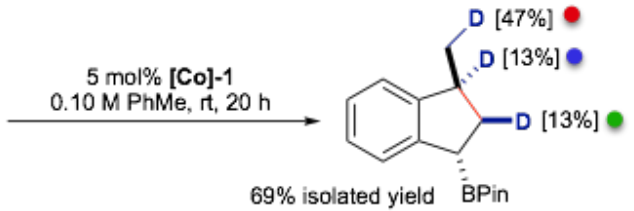

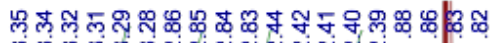

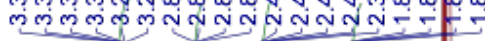

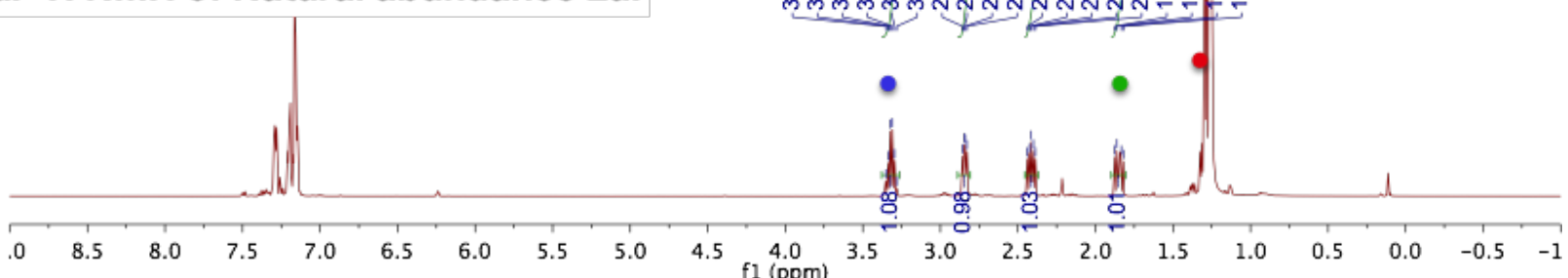

b. ${ }^{1}$ H NMR 2a-D.

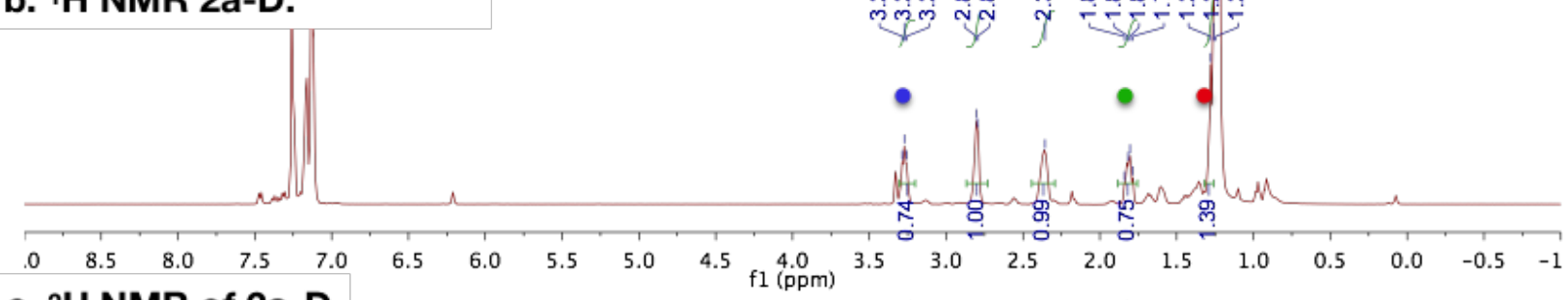

c. ${ }^{2 H}$ NMR of 2a-D.

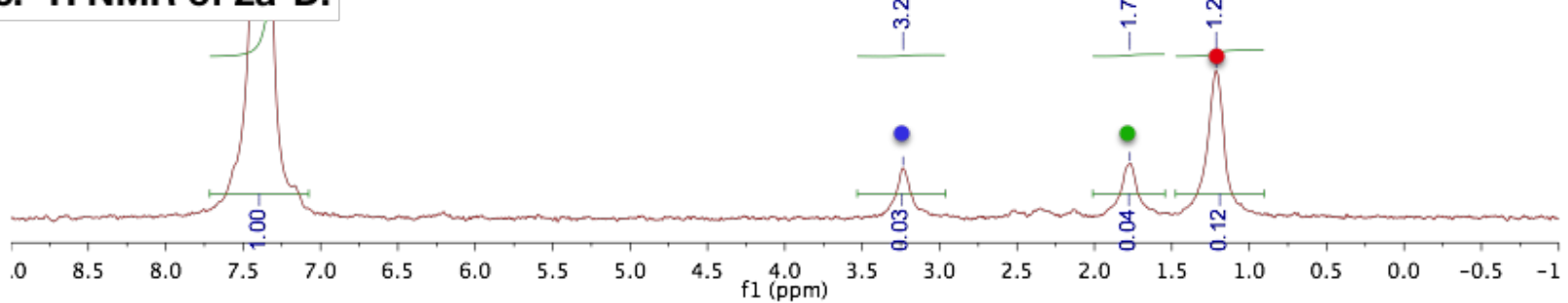

Figure S2. a. ${ }^{1} \mathrm{H}$ NMR $\left(500 \mathrm{MHz}, \mathrm{CDCl}_{3}, 23^{\circ} \mathrm{C}\right)$ spectra of natural abundance 2a. b. ${ }^{1} \mathrm{H}$ NMR $\left(500 \mathrm{MHz}, \mathrm{CDCl}_{3}, 23^{\circ} \mathrm{C}\right)$ spectra of $2 \mathrm{a}-\mathrm{D} . \mathrm{c} .{ }^{2} \mathrm{H}$ NMR $\left(400 \mathrm{MHz}, \mathrm{CHCl}_{3}, 23{ }^{\circ} \mathrm{C}, \mathrm{C}_{6} \mathrm{D}_{6}\right.$ internal standard) spectra of $2 \mathrm{a}-\mathrm{D}$. 


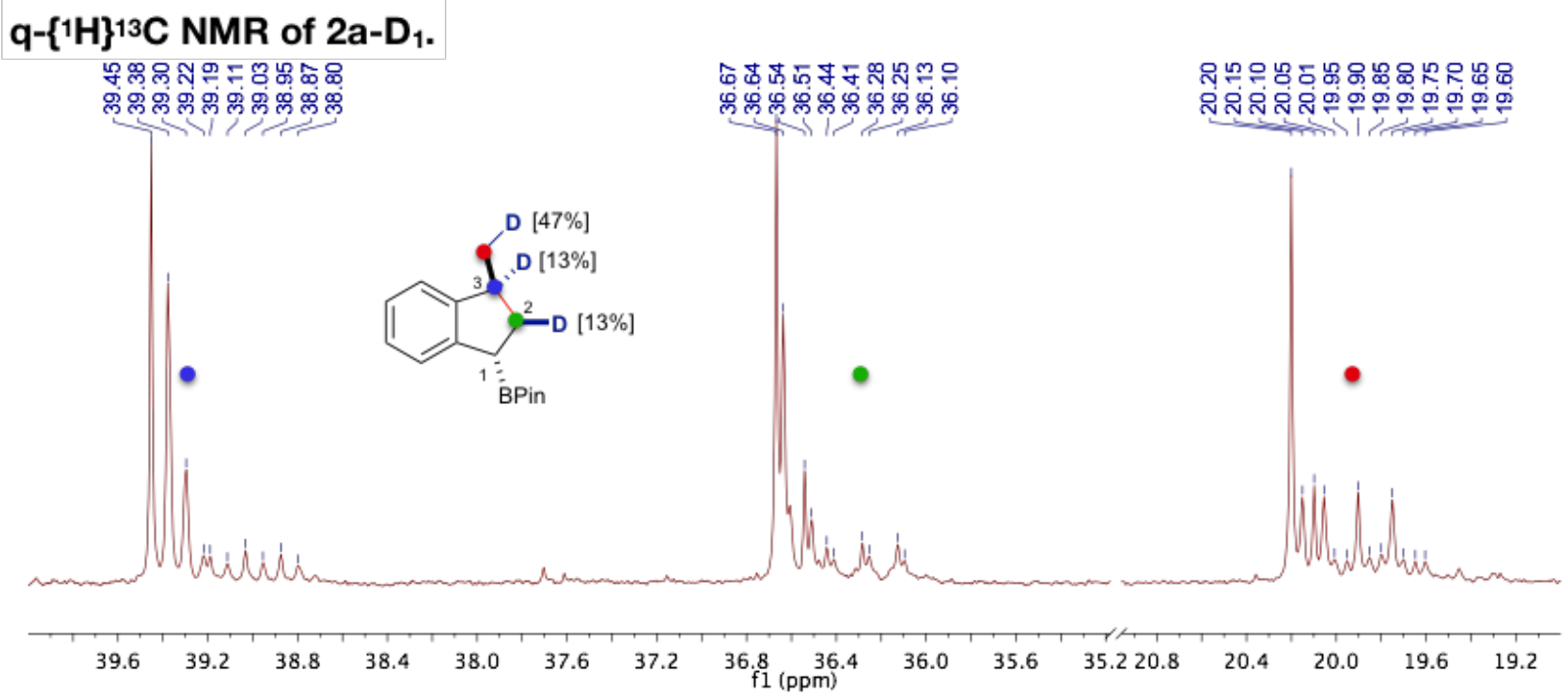

Figure S3. Quantitative ${ }^{13} \mathrm{C}\left\{{ }^{1} \mathrm{H}\right\} \operatorname{NMR}\left(126 \mathrm{MHz} \mathrm{CDCl}_{3}, 23^{\circ} \mathrm{C}\right)$ spectra of $2 \mathrm{a}-\mathrm{D}$.

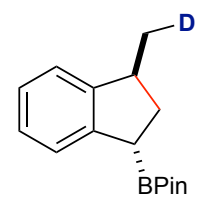

$\mathrm{m} / \mathrm{z}$ (calc'd): $259.18539(100.0 \%), 258.18902(24.8 \%), 260.18874(17.3 \%), 259.19237(4.3 \%)$ $\mathrm{m} / \mathrm{z}$ (found): 259.1869 (100\%), 258.1821 (73.0\%), 260.1916 (62.6\%), $261.1963(21.9 \%), 257.1812(15.6 \%)$
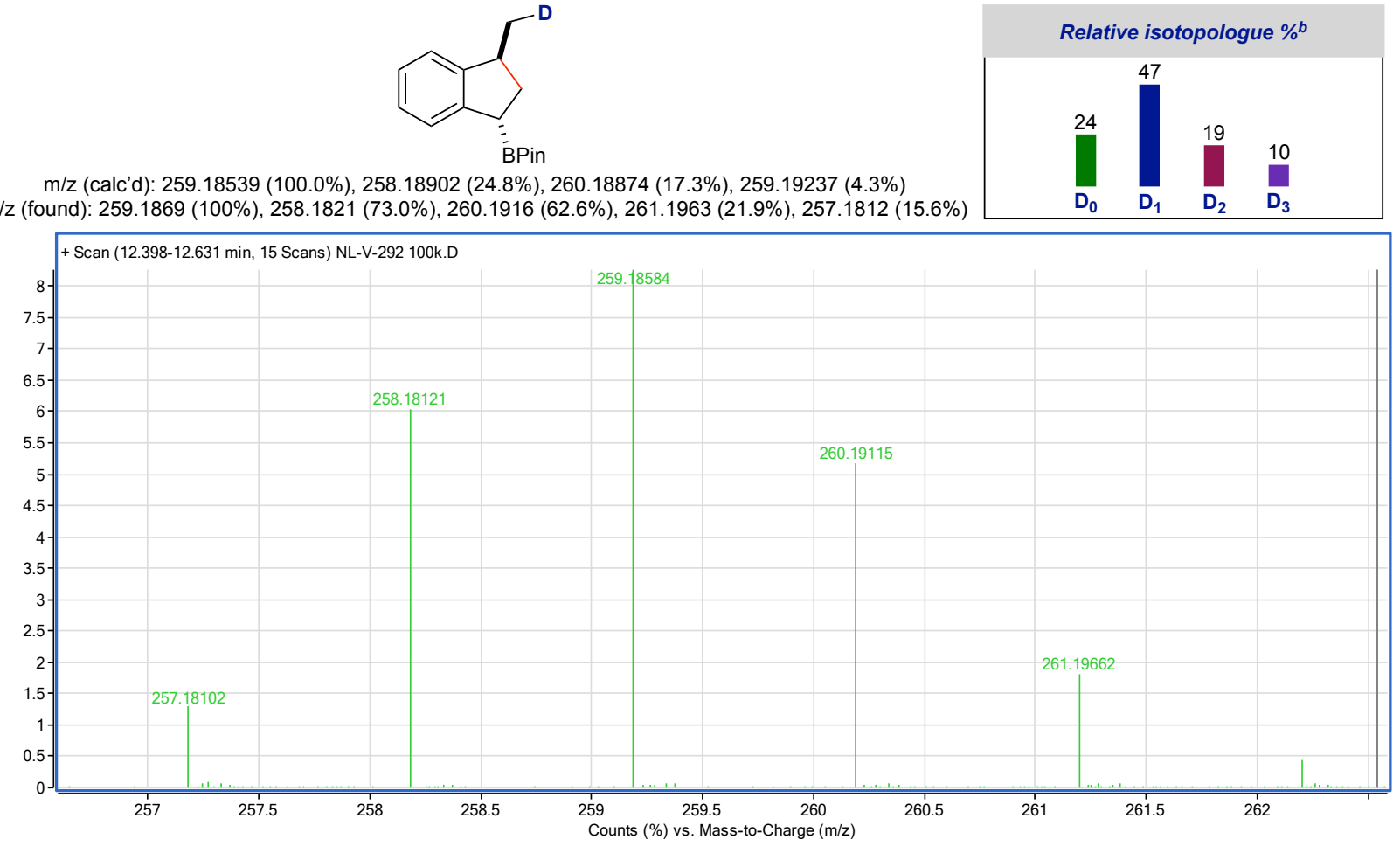

Figure S4. GC-MS of 2a-D establishing mixture of isotopologues. Relative abundances of each species takes into account the natural abundance of ${ }^{10} \mathrm{~B}$ and ${ }^{13} \mathrm{C}$ isotope content of each mass peak. Calculated mass spec is for major isotopologue $2 \mathrm{a}-\boldsymbol{d}_{1}$. 
2H NMR of 1a-D.

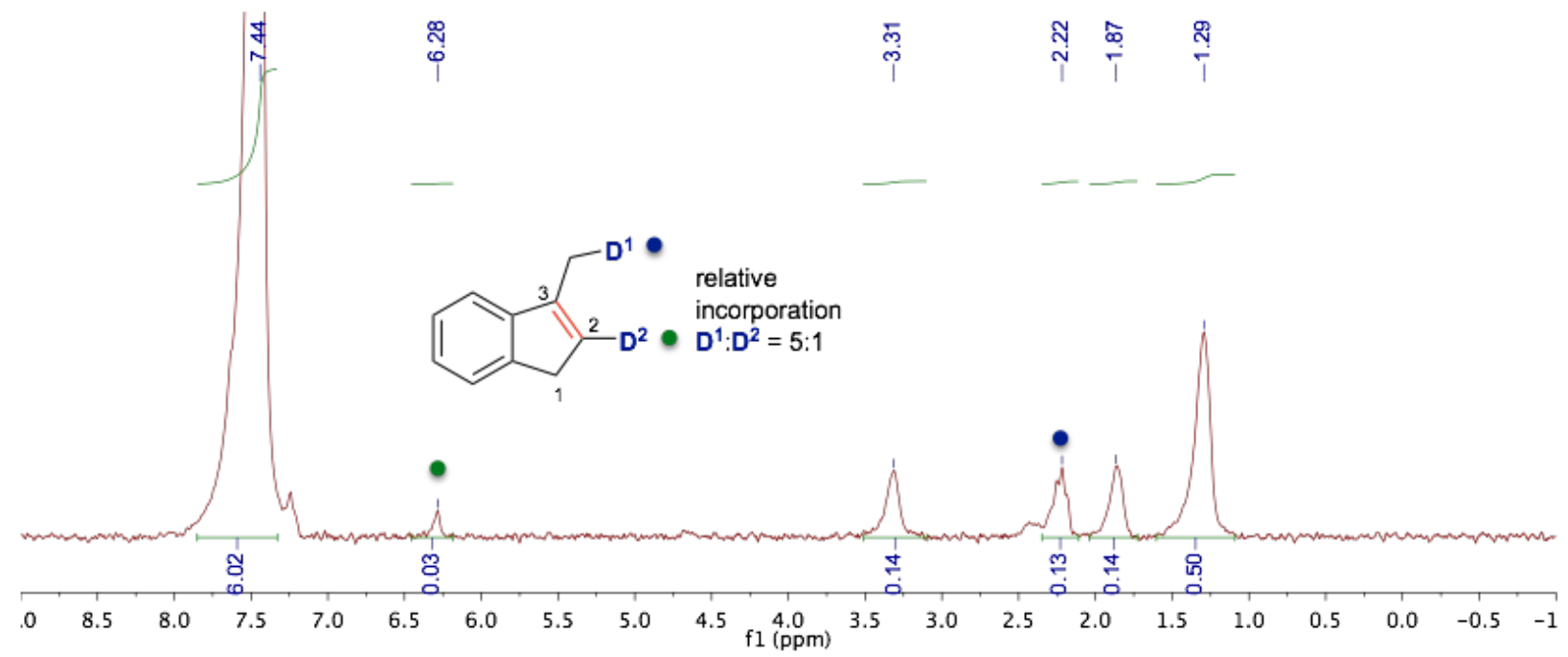

Figure S5. ${ }^{2} \mathrm{H}$ NMR (400 MHz, $\mathrm{CHCl}_{3}, 23^{\circ} \mathrm{C}, \mathrm{C}_{6} \mathrm{D}_{6}$ internal standard) spectra of 1a-D recovered after $10 \mathrm{~h}$ of reaction time.

Deuteroboration of 1-exo-methylene-indane (1 aa).

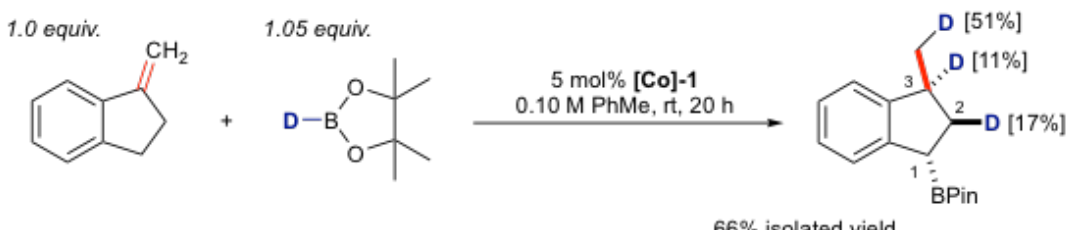

\section{$q-\left\{{ }^{1} H{ }^{13} C\right.$ NMR of 2aa-D.}

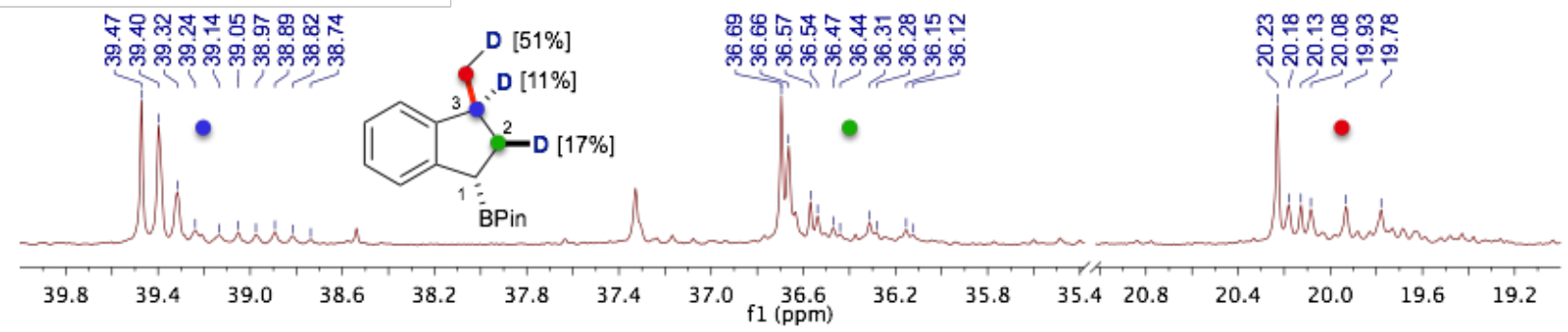

Figure S6. Quantitative ${ }^{13} \mathrm{C}\left\{{ }^{1} \mathrm{H}\right\} \mathrm{NMR}\left(126 \mathrm{MHz}, \mathrm{CDCl}_{3}, 23^{\circ} \mathrm{C}\right)$ spectra of 2aa-D. 


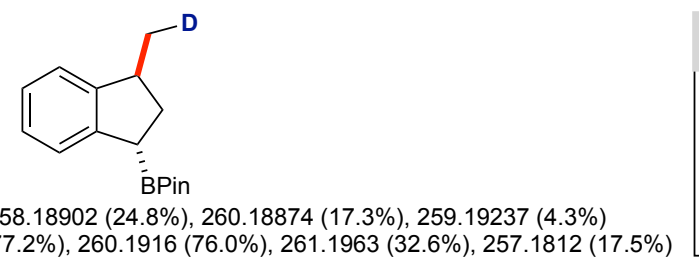

Relative isotopologue $\%^{b}$
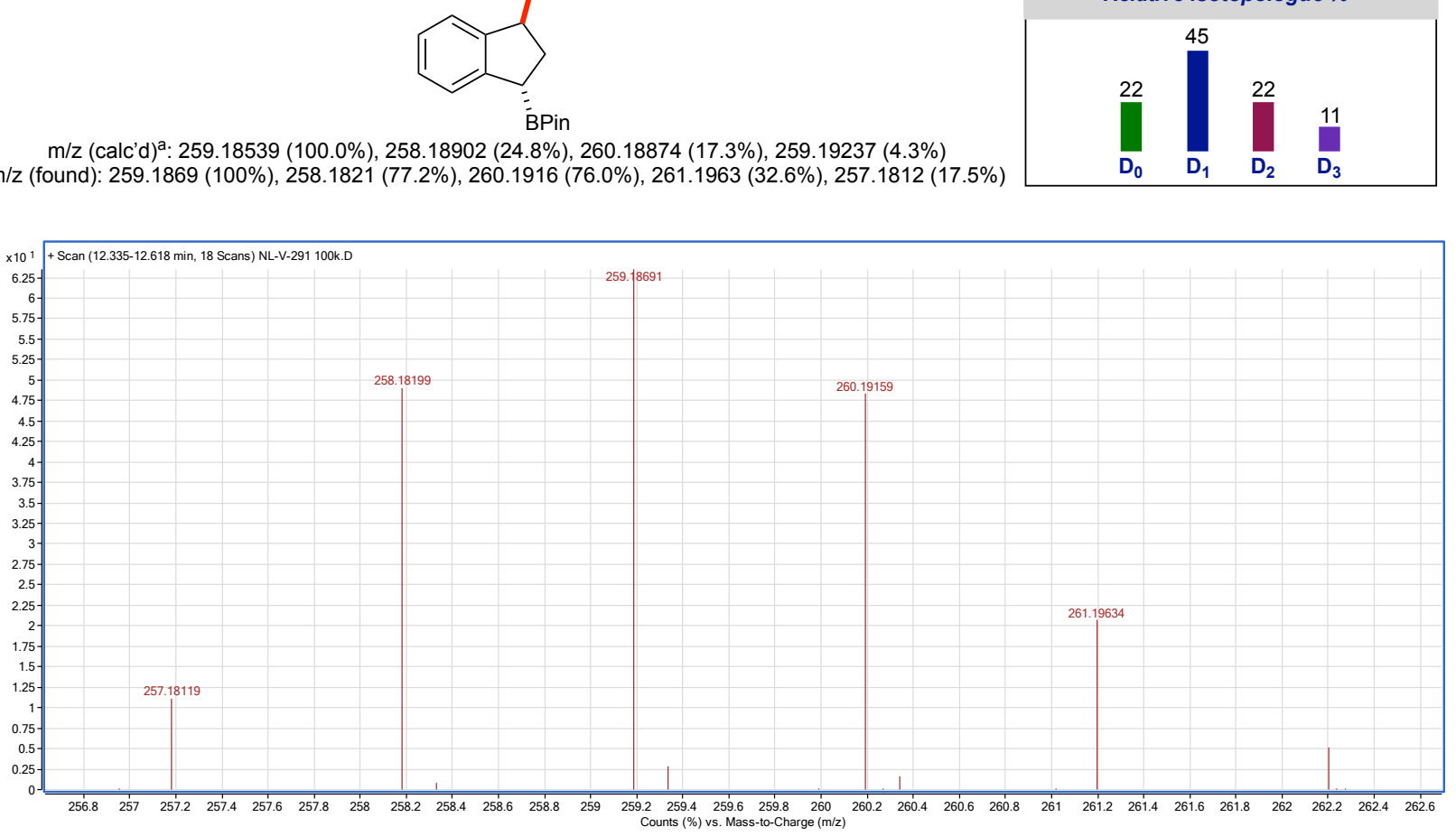

Figure S7. GC-MS of 2aa-D establishing mixture of isotopologues. ${ }^{a}$ Calculated mass spec is for major isotopologue $2 \mathrm{aa}-\boldsymbol{d}_{1}{ }^{\mathrm{b}}$ Relative abundances of each species takes into account the natural abundance of ${ }^{10} \mathrm{~B}$ and ${ }^{13} \mathrm{C}$ isotope content of each mass peak.

Deuteroboration of 1 -methyl- $1 \mathrm{H}$-indene (1ab). 


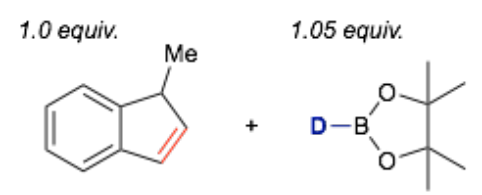

a. ${ }^{1} \mathrm{H}$ NMR of Natural abundance $2 \mathrm{a}$.

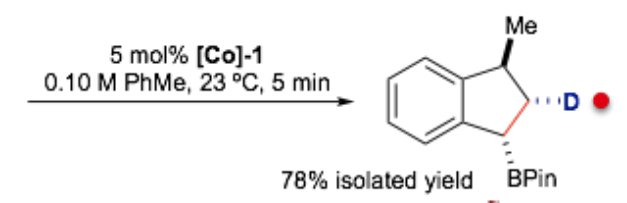

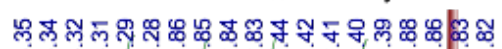

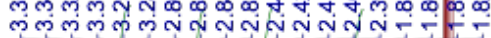

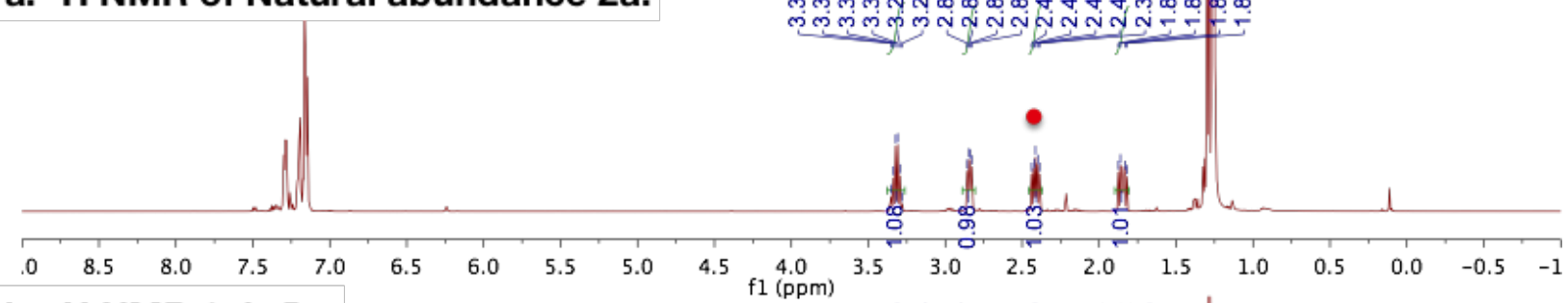

\section{b. ${ }^{1}$ H NMR 2ab-D .}

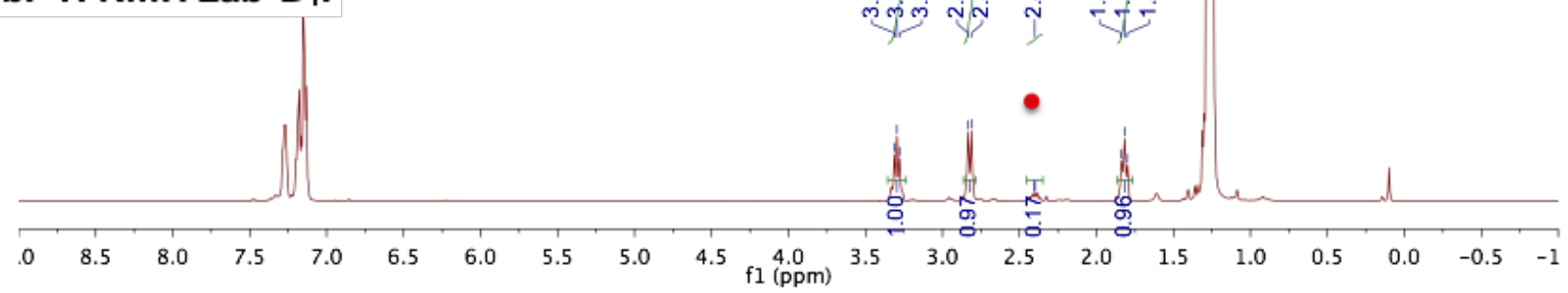

\section{c. ${ }^{2} \mathrm{H}$ NMR of $2 \mathrm{ab}-\mathrm{D}_{1}$.}

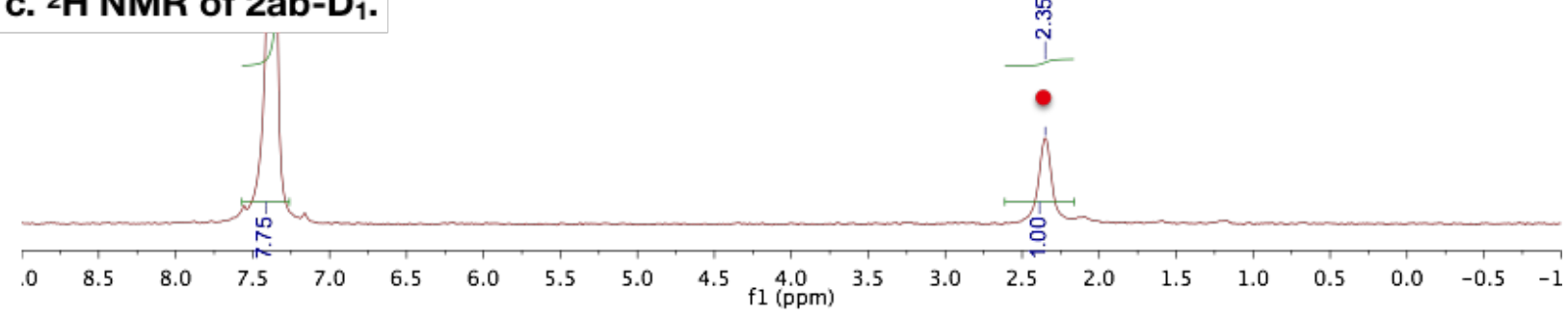

Figure S8. a. ${ }^{1} \mathrm{H}$ NMR $\left(500 \mathrm{MHz}, \mathrm{CDCl}_{3}, 23^{\circ} \mathrm{C}\right)$ spectra of natural abundance 2a. b. ${ }^{1} \mathrm{H}$ NMR $\left(500 \mathrm{MHz}, \mathrm{CDCl}_{3}, 23^{\circ} \mathrm{C}\right)$ spectra of $2 \mathrm{ab}-\mathrm{D}_{1}$. C. ${ }^{2} \mathrm{H}$ NMR $\left(500 \mathrm{MHz}, \mathrm{CHCl}_{3}, 23^{\circ} \mathrm{C}, \mathrm{C}_{6} \mathrm{D}_{6}\right.$ internal standard) spectra of $2 a b-D_{1}$.

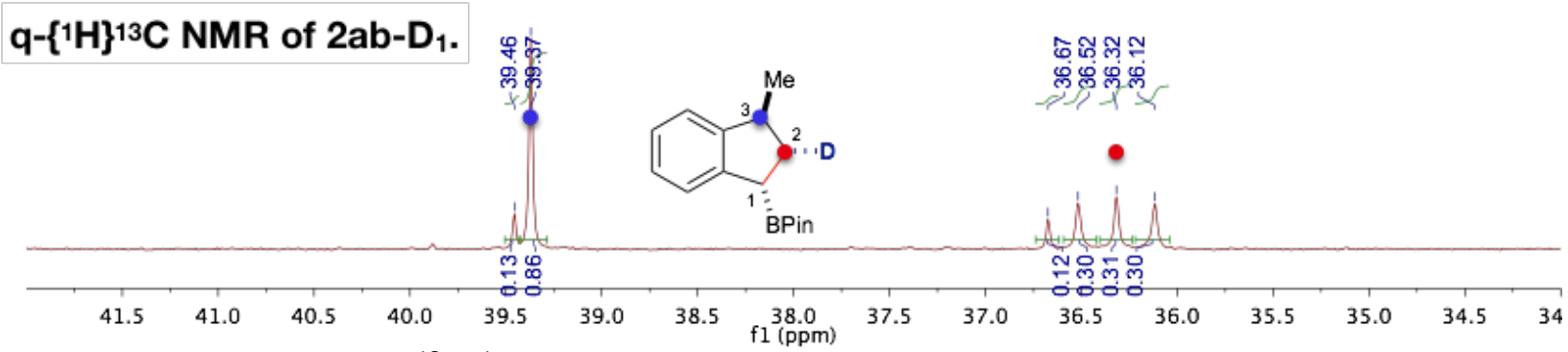

Figure S9. Quantitative ${ }^{13} \mathrm{C}\left\{{ }^{1} \mathrm{H}\right\} \mathrm{NMR}\left(126 \mathrm{MHz}, \mathrm{CDCl}_{3}, 23^{\circ} \mathrm{C}\right)$ spectra of $2 \mathrm{ab}-\mathrm{D}_{1}$. 


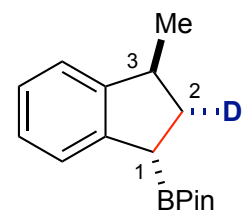

m/z (calc'd): 259.18539 (100.0\%), 258.18902 (24.8\%), 260.18874 (17.3\%), 259.19237 (4.3\%) $\mathrm{m} / \mathrm{z}$ (found): 259.18585 (100.0\%), 258.18713 (24.9\%), $260.19028(24.6 \%)$

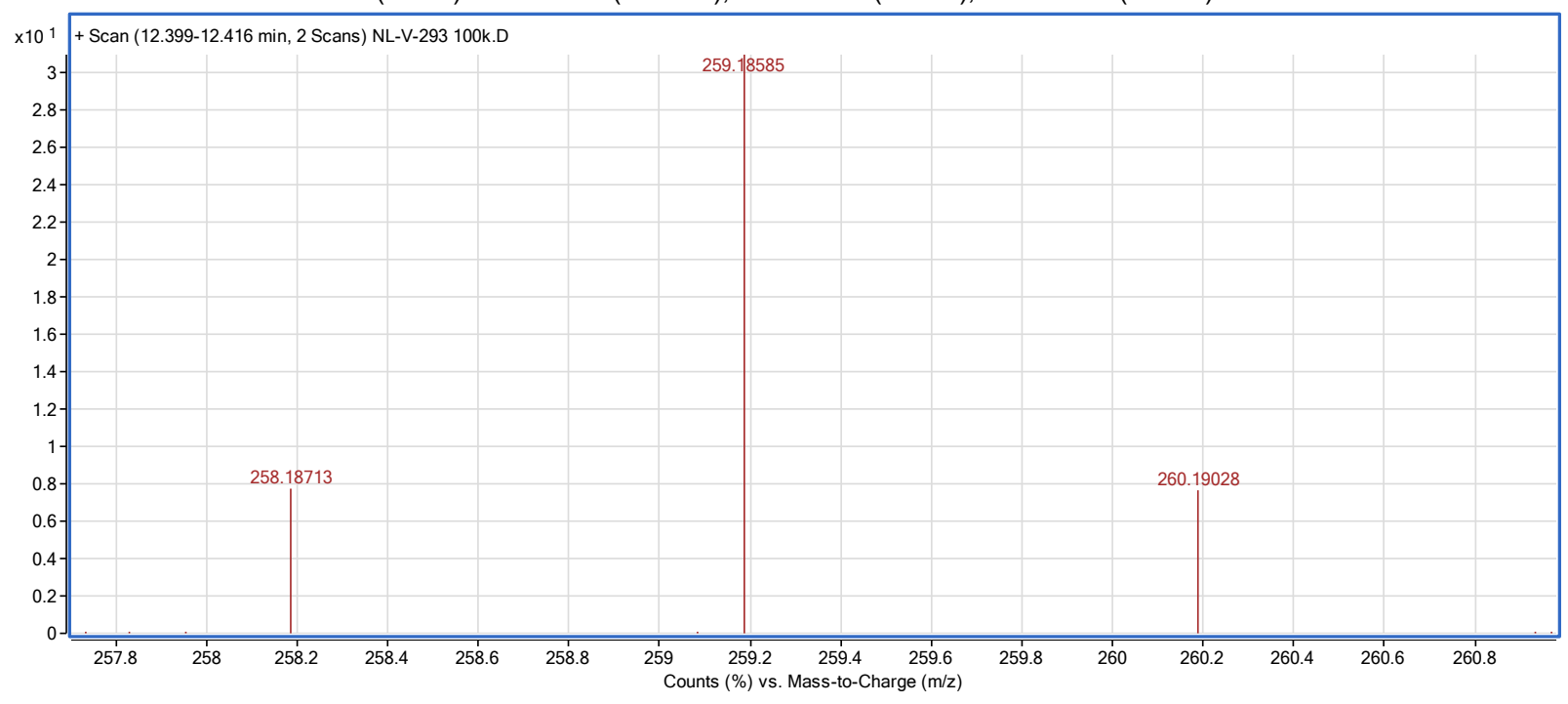

Figure S10. GC-MS of $2 a b-D_{1}$ establishing single isotopologue.

Deuteroboration of 3-ethyl-1 $H$-indene (1c). 

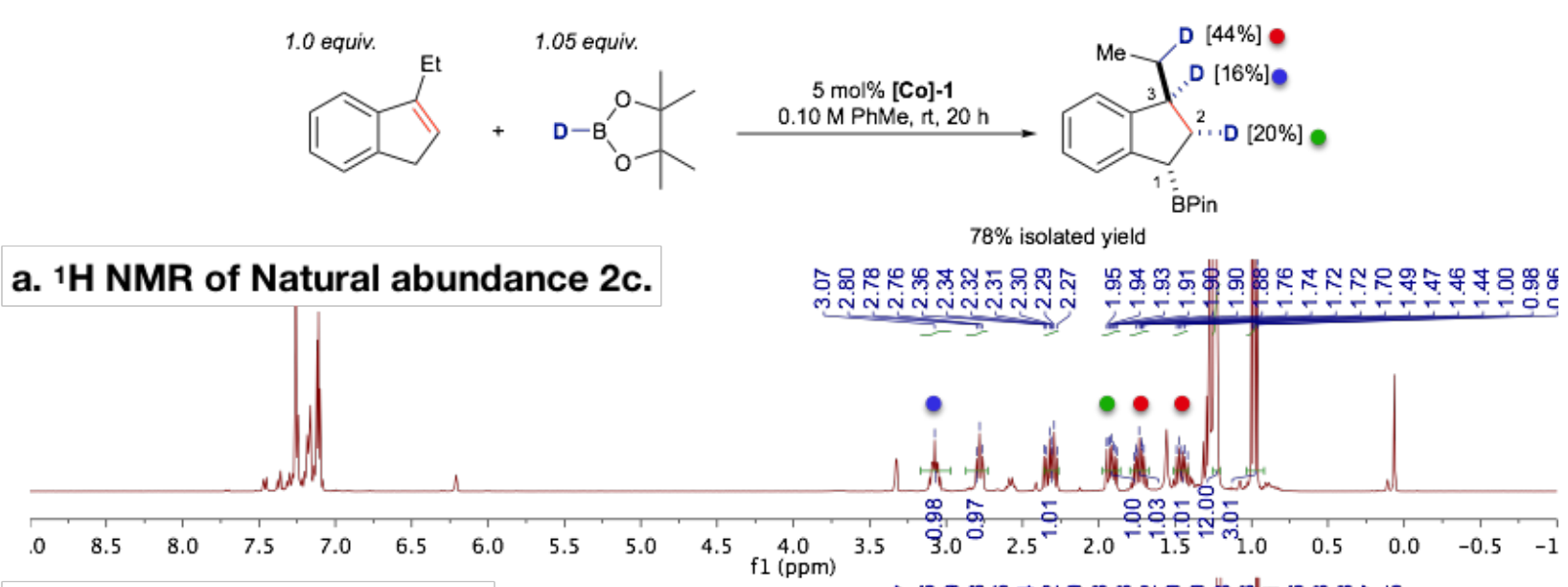

b. ${ }^{1 H}$ NMR 2c-D.

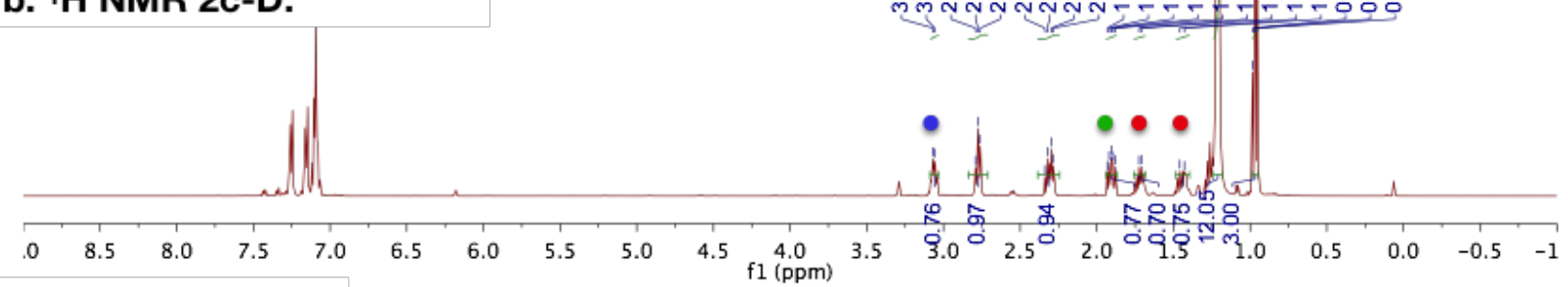

c. ${ }^{2 H}$ NMR of 2c-D.

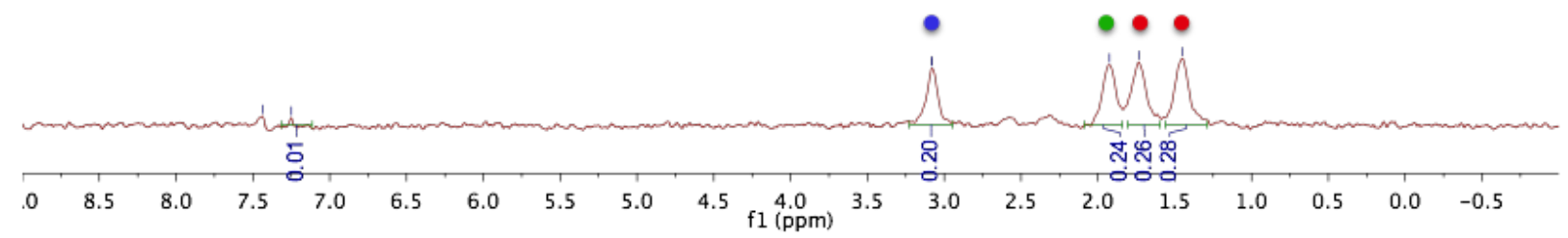

Figure S11. a. ${ }^{1} \mathrm{H}$ NMR (500 MHz, $\left.\mathrm{CDCl}_{3}, 23^{\circ} \mathrm{C}\right)$ spectra of natural abundance 2c. b. ${ }^{1} \mathrm{H}$ NMR $\left(500 \mathrm{MHz}, \mathrm{CDCl}_{3}, 23{ }^{\circ} \mathrm{C}\right)$ spectra of $2 \mathrm{c}-\mathrm{D}$. c. ${ }^{2} \mathrm{H} \mathrm{NMR}\left(500 \mathrm{MHz}, \mathrm{CHCl}_{3}, 23{ }^{\circ} \mathrm{C}, \mathrm{C}_{6} \mathrm{D}_{6}\right.$ internal standard) spectra of $2 \mathrm{C}-\mathrm{D}$. 


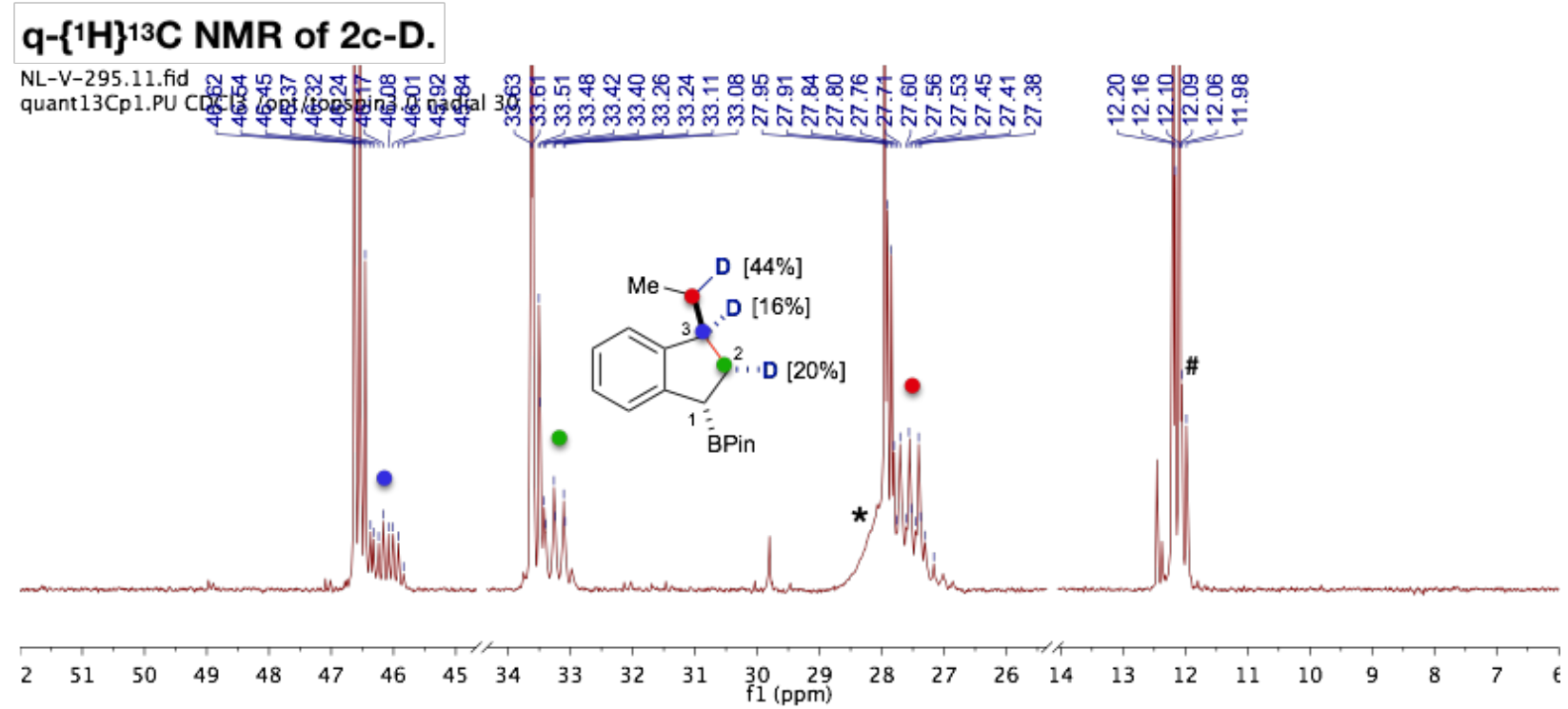

Figure S12. Quantitative ${ }^{13} \mathrm{C}\left\{{ }^{1} \mathrm{H}\right\} N M R\left(126 \mathrm{MHz}, \mathrm{CDCl}_{3}, 23^{\circ} \mathrm{C}\right)$ spectra of $2 \mathrm{C}-\mathrm{D}$. *Broadening due to overlapping with 1-BPin carbon. \#Peaks correspond to methyl carbon and secondary isotopic perturbation from adjacent deuterium labeled carbon positions.

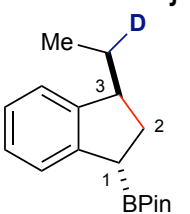

$\mathrm{m} / \mathrm{z}$ (calc'd) $)^{\mathrm{a}}: 273.20104(100.0 \%), 272.20467(24.8 \%), 274.20439(18.4 \%)$ $\mathrm{m} / \mathrm{z}$ (found): 273.2061 (100.0\%), 272.2008 (89.0\%), 274.2097 (79.6\%), 275.2135 (35.1\%), $271.1989(26.5 \%)$

Relative isotopologue $\%^{b}$

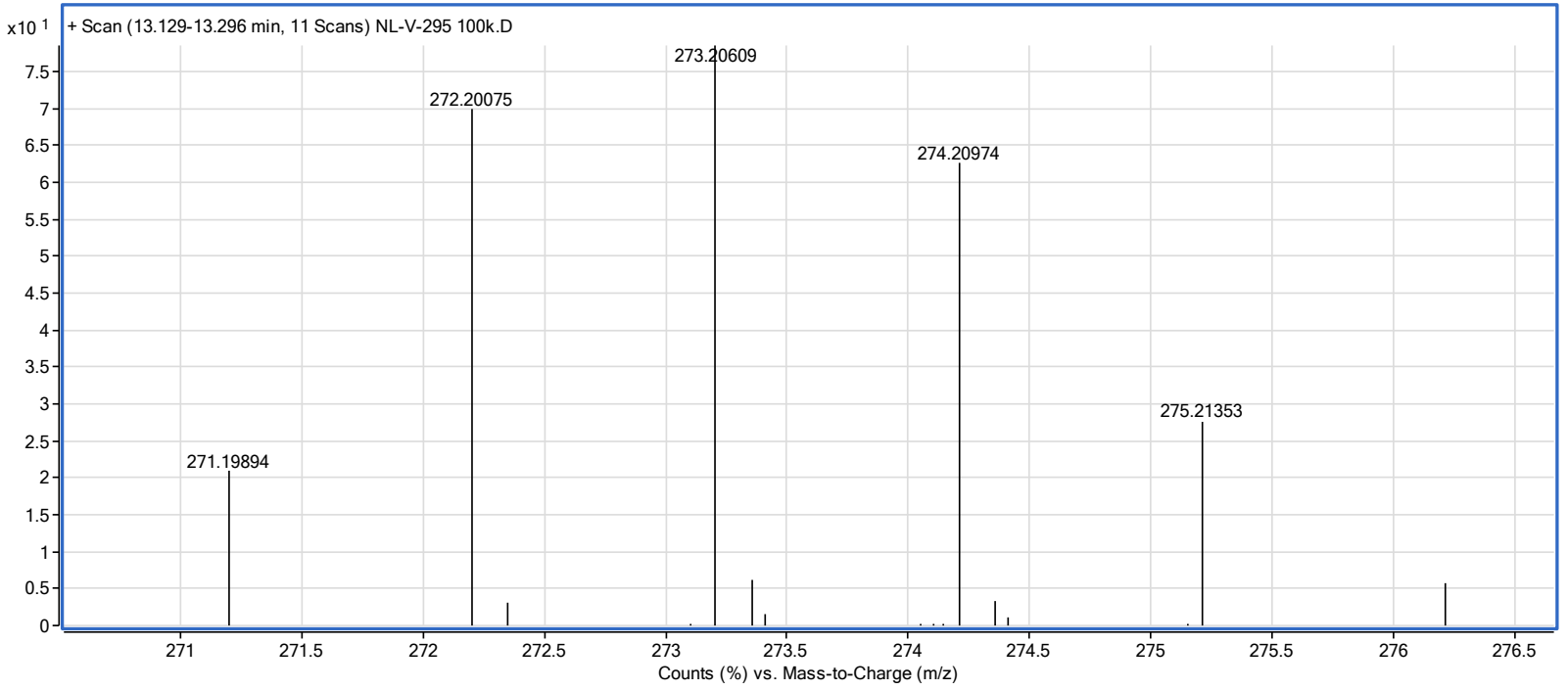

Figure S13. GC-MS of 2c-D establishing mixture of isotopologues. ${ }^{a}$ Calculated mass spec is for major isotopologue $2 \mathrm{c}-d_{1}$. ${ }^{\text {b }}$ Relative abundances of each species takes into account the natural abundance of ${ }^{10} \mathrm{~B}$ and ${ }^{13} \mathrm{C}$ isotope content of each mass peak. 
Deuteroboration of 1-ethylene-2,3-dihydro- $1 \mathrm{H}$-indene (1ca).

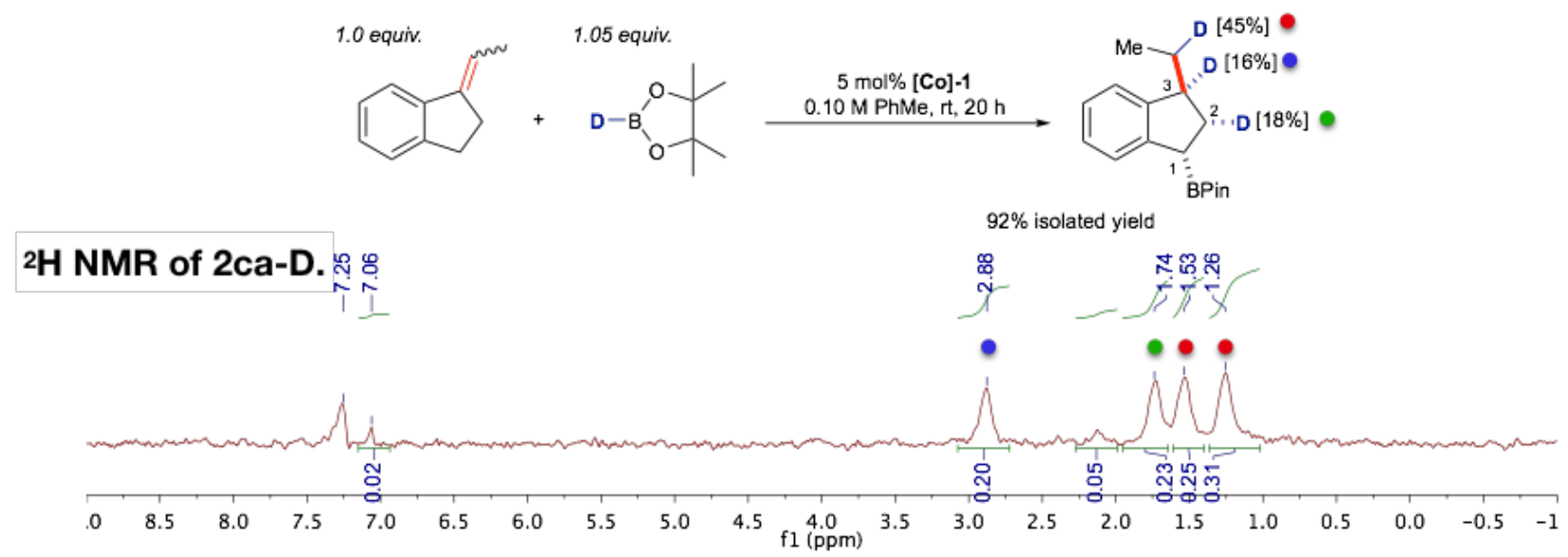

Figure $\mathrm{S} 14 .{ }^{2} \mathrm{H} \mathrm{NMR}\left(500 \mathrm{MHz}, \mathrm{CHCl}_{3}, 23^{\circ} \mathrm{C}, \mathrm{C}_{6} \mathrm{D}_{6}\right.$ internal standard) spectra of 2ca-D.

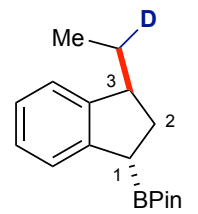

$\mathrm{m} / \mathrm{z}$ (calc'd) a: $273.20104(100.0 \%), 272.20467(24.8 \%), 274.20439(18.4 \%)$

$\mathrm{m} / \mathrm{z}$ (found): $273.2027(100.0 \%), 272.1982(71.3 \%), 274.2081(65.7 \%), 275.2133(25.6 \%), 271.1966(17.8 \%)$
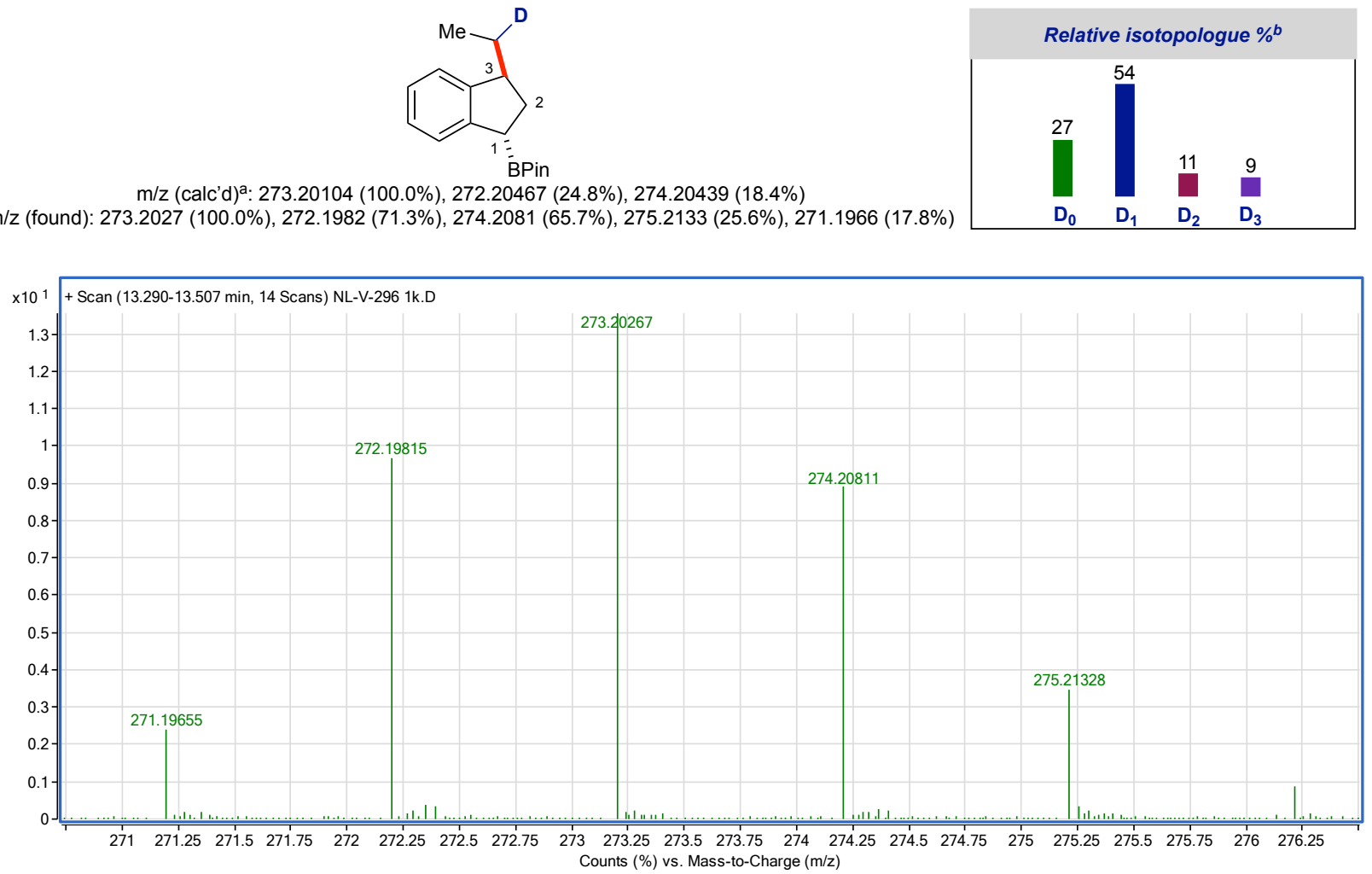

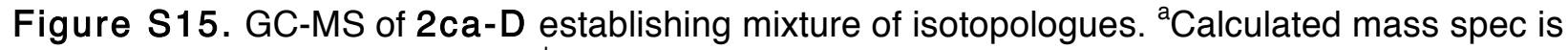
for major isotopologue $2 \mathrm{ca}-\boldsymbol{d}_{1}{ }^{\text {b }}$ Relative abundances of each species takes into account the natural abundance of ${ }^{10} \mathrm{~B}$ and ${ }^{13} \mathrm{C}$ isotope content of each mass peak. 
Deuteroboration of 3-phenyl-1H-indene (1e).
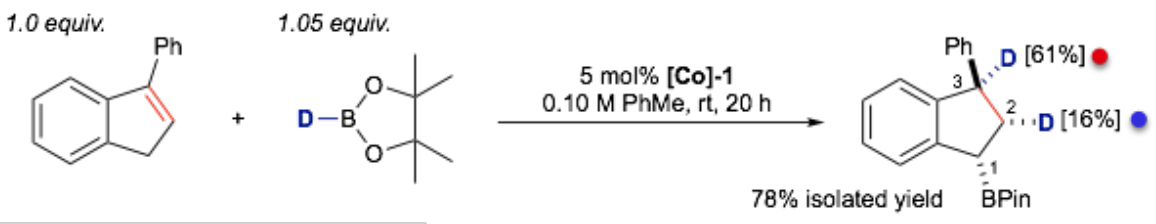

a. ${ }^{1 H}$ NMR of Natural abundance $2 e$.

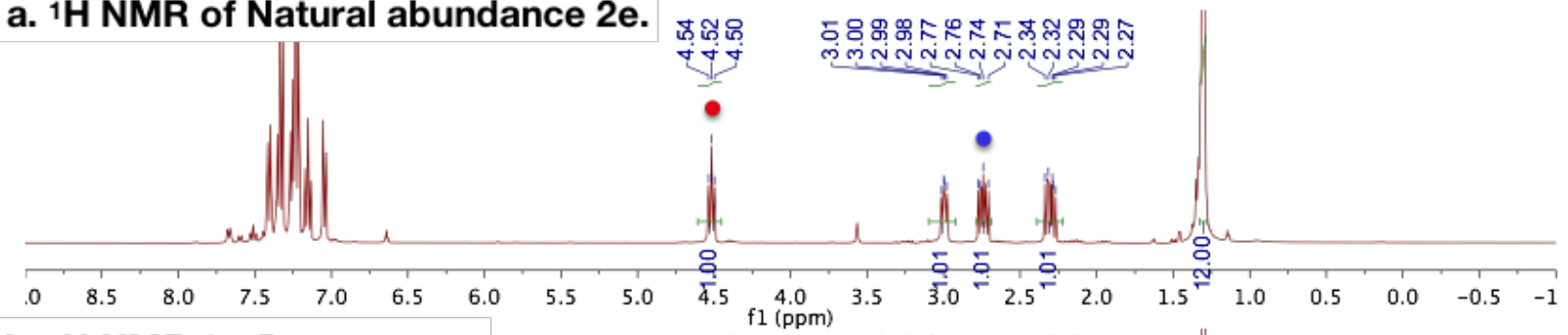

b. ${ }^{1} H$ NMR 2e-D.

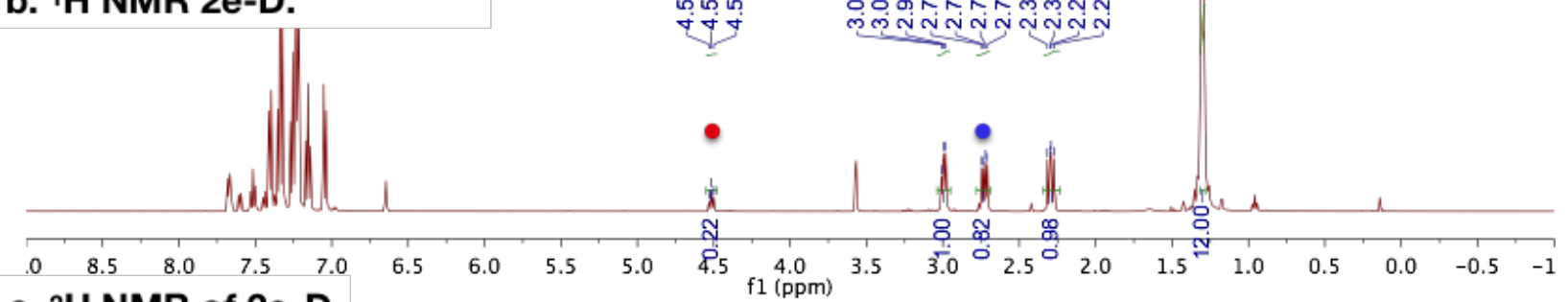

c. ${ }^{2} \mathrm{H}$ NMR of $2 \mathrm{e}-\mathrm{D}$.

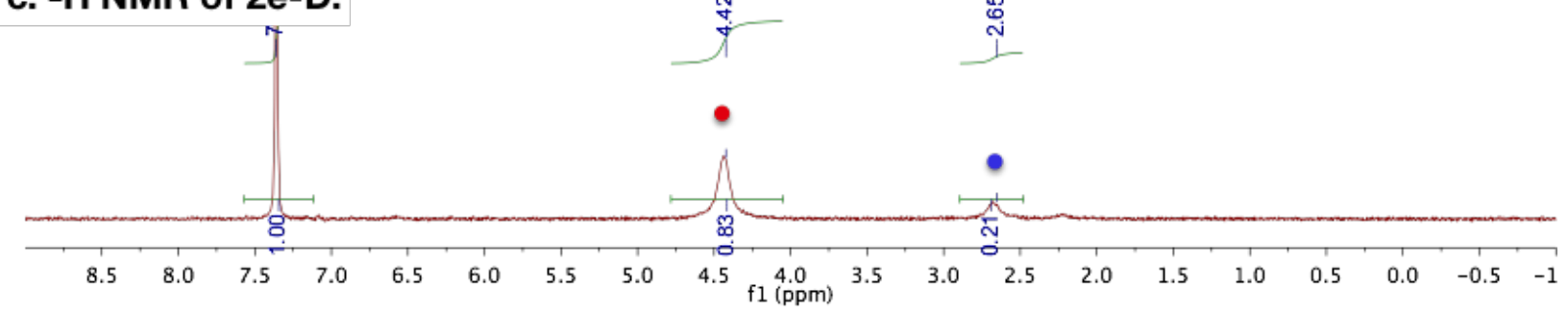

Figure S16. a. ${ }^{1} \mathrm{H}$ NMR $\left(500 \mathrm{MHz}, \mathrm{CDCl}_{3}, 23^{\circ} \mathrm{C}\right)$ spectra of natural abundance 2e. b. ${ }^{1} \mathrm{H}$ NMR $\left(500 \mathrm{MHz}, \mathrm{CDCl}_{3}, 23^{\circ} \mathrm{C}\right)$ spectra of $2 \mathrm{e}-\mathrm{D} . \mathrm{c}^{2}{ }^{2} \mathrm{H}$ NMR $\left(400 \mathrm{MHz}, \mathrm{CHCl}_{3}, 23^{\circ} \mathrm{C}, \mathrm{C}_{6} \mathrm{D}_{6}\right.$ internal standard) spectra of $2 e-D$. 


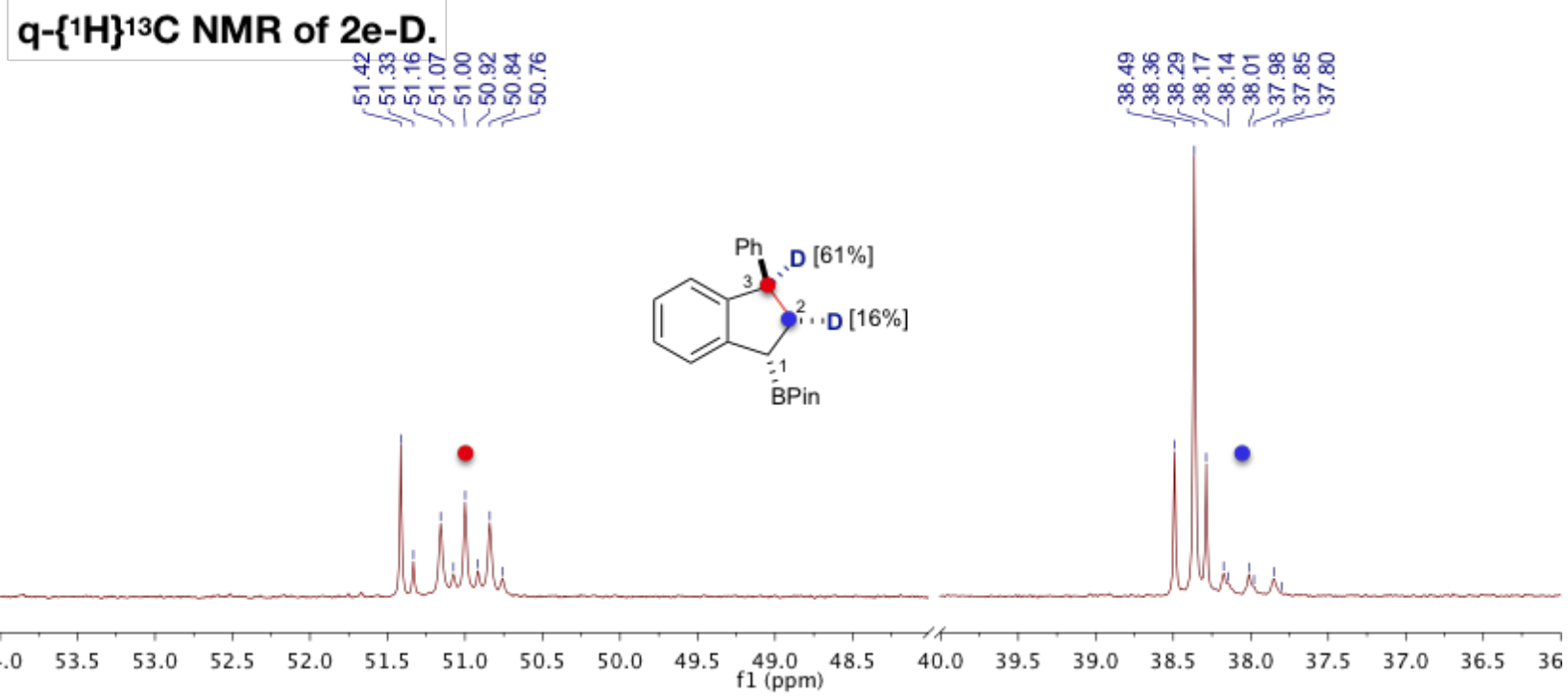

Figure S17. Quantitative ${ }^{13} \mathrm{C}\left\{{ }^{1} \mathrm{H}\right\} \mathrm{NMR}\left(126 \mathrm{MHz}, \mathrm{CDCl}_{3}, 23^{\circ} \mathrm{C}\right)$ spectra of $2 \mathrm{e}-\mathrm{D}$.
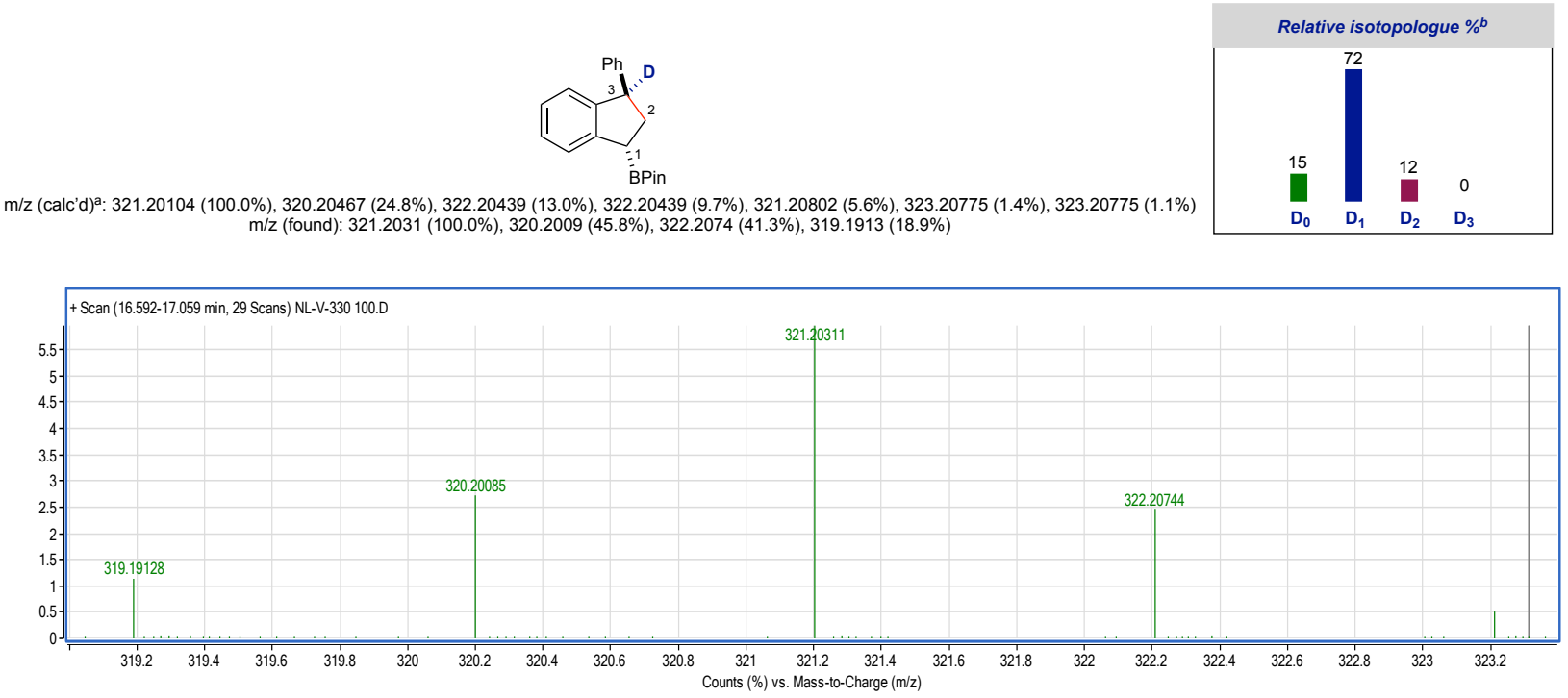

Figure S18. GC-MS of $2 e-D$ establishing mixture of isotopologues. ${ }^{a}$ Calculated mass spec is for major isotopologue $2 \mathrm{e}-d_{1}$. ${ }^{\mathrm{b}}$ Relative abundances of each species takes into account the natural abundance of ${ }^{10} \mathrm{~B}$ and ${ }^{13} \mathrm{C}$ isotope content of each mass peak.

Deuteroboration of 2-(1H-inden-3-yl)-4,4,5,5-tetramethyl-1,3,2-dioxaborolane (1n). 

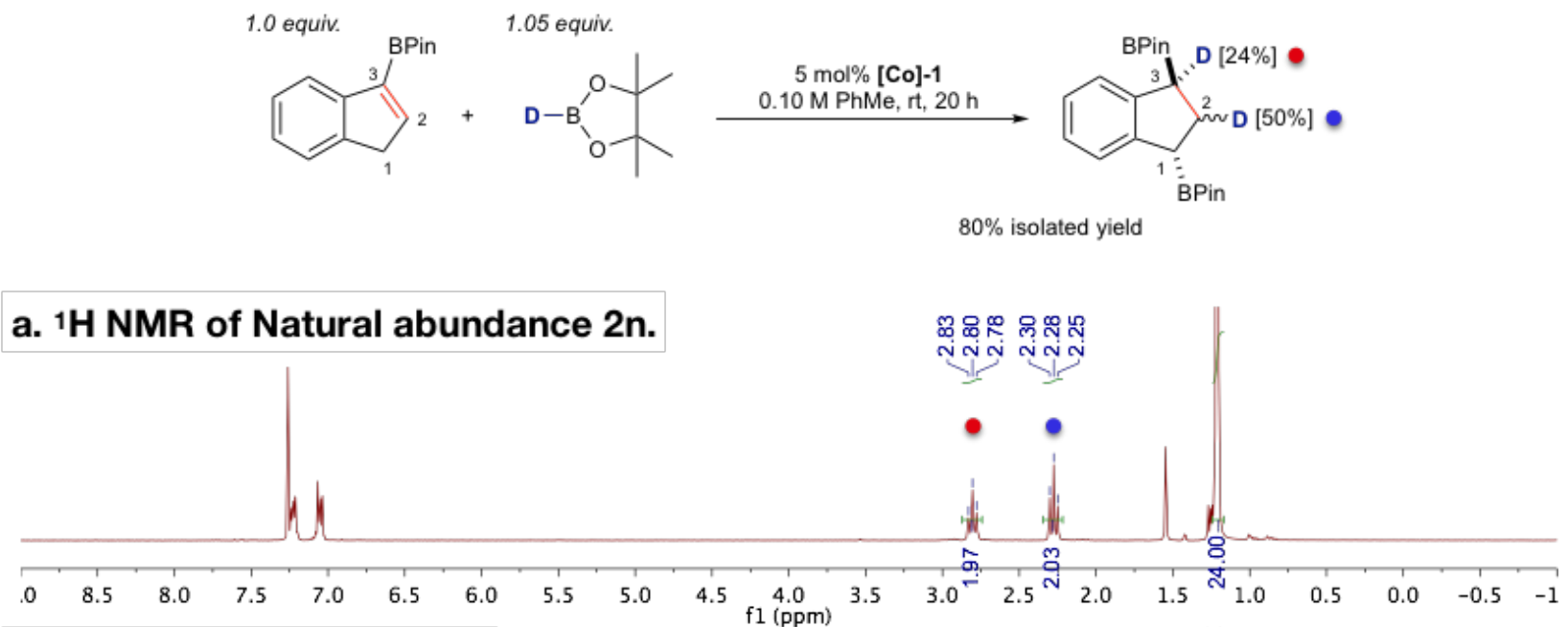

b. ${ }^{1}$ H NMR 2n-D.

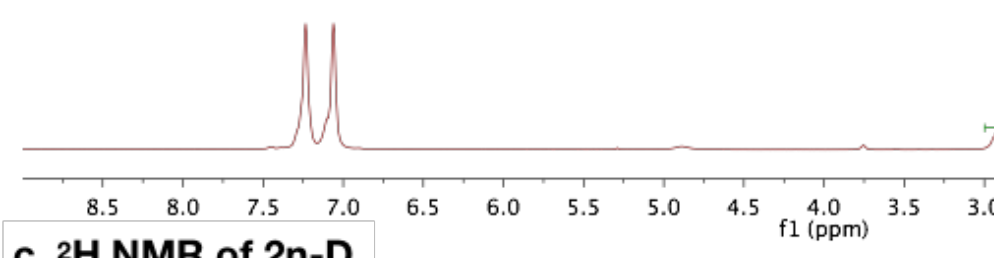

c. ${ }^{2}$ H NMR of $2 n-D$.

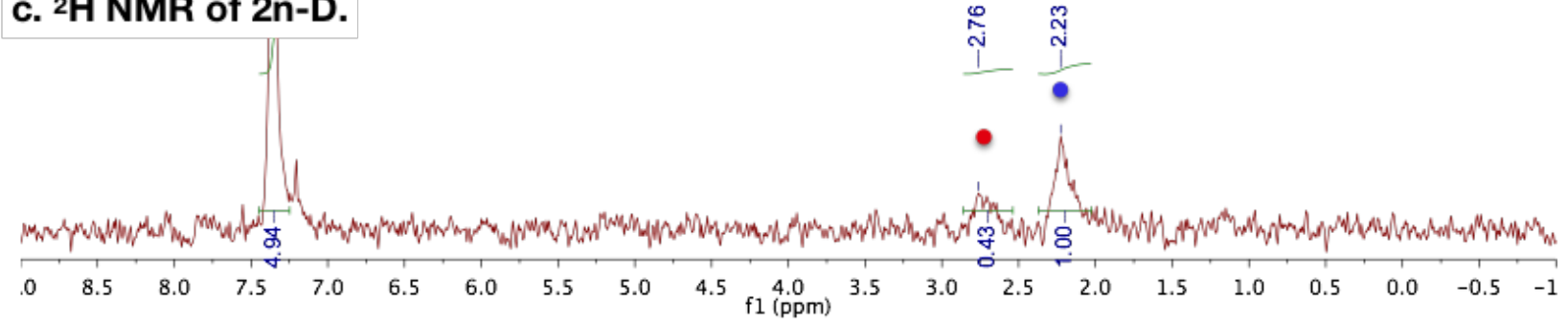

Figure S19. a. ${ }^{1} \mathrm{H}$ NMR $\left(500 \mathrm{MHz}, \mathrm{CDCl}_{3}, 23{ }^{\circ} \mathrm{C}\right)$ spectra of natural abundance $2 \mathrm{n} . \mathrm{b} .{ }^{1} \mathrm{H} \mathrm{NMR}$ $\left(500 \mathrm{MHz}, \mathrm{CDCl}_{3}, 23{ }^{\circ} \mathrm{C}\right)$ spectra of $2 \mathrm{n}-\mathrm{D}$. c. ${ }^{2} \mathrm{H} \mathrm{NMR}\left(400 \mathrm{MHz}, \mathrm{CHCl}_{3}, 23{ }^{\circ} \mathrm{C}, \mathrm{C}_{6} \mathrm{D}_{6}\right.$ internal standard) spectra

of

$2 n-D$. 

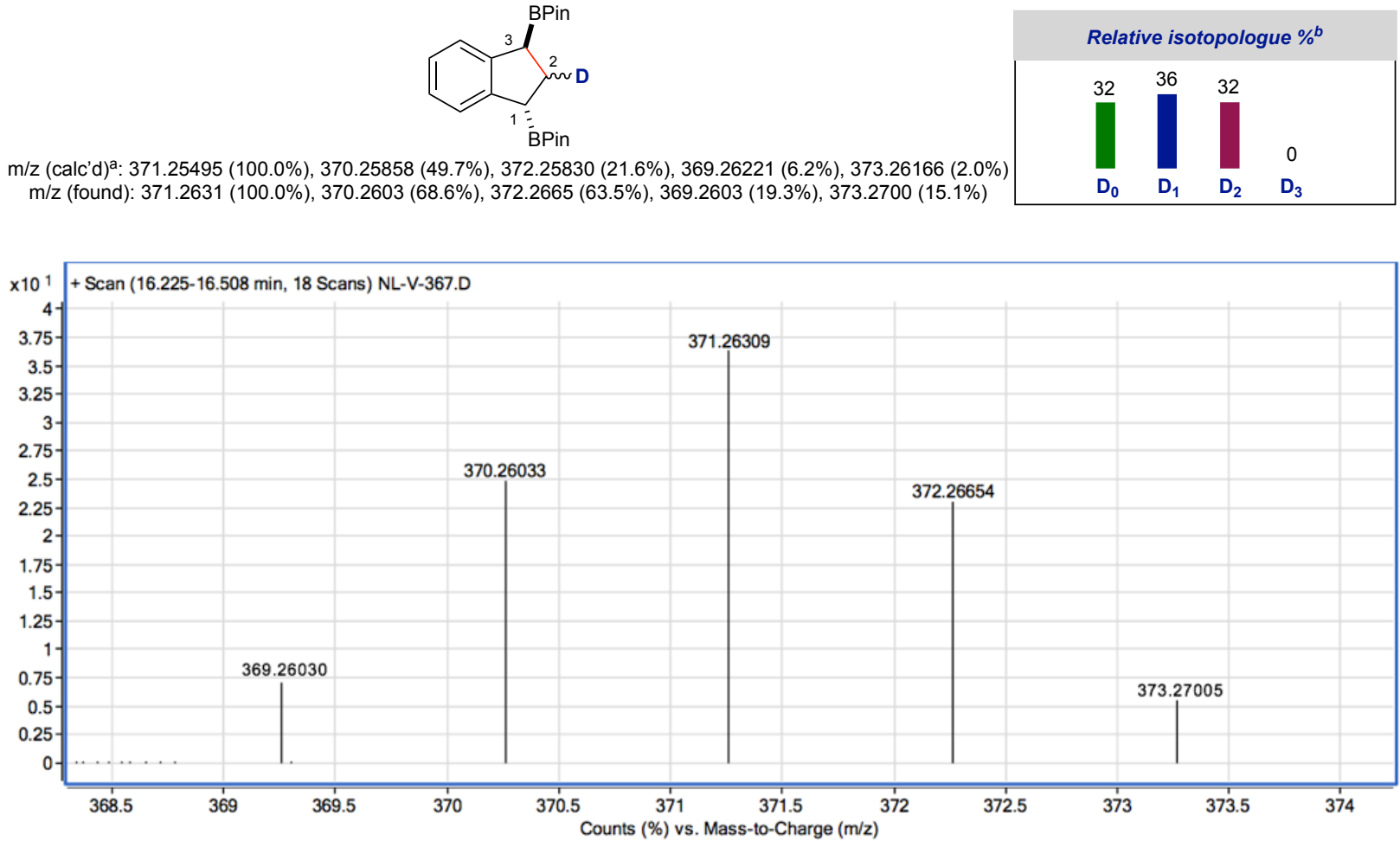

Figure S20. GC-MS of $2 n-D$ establishing mixture of isotopologues. ${ }^{a}$ Calculated mass spec is for major isotopologue $2 \mathrm{n}-d_{1}$. ${ }^{\text {b }}$ Relative abundances of each species takes into account the natural abundance of ${ }^{10} \mathrm{~B}$ and ${ }^{13} \mathrm{C}$ isotope content of each mass peak.

\section{Catalytic Hydroboration of Dialins.}

Procedure for Catalytic Hydroboration of Dialins

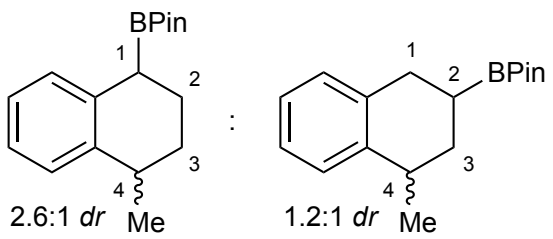

(8e). Prepared according to the general procedure with the following modification. A $4 \mathrm{~mL}$ scintillation vial was charged in the glove box with $0.002 \mathrm{mg}$ (0.005 mmol, $1 \mathrm{~mol} \%$ ) [Co]-1 and a magnetic stir bar. Toluene (1 mL) was then added followed by $0.072 \mathrm{mg}$ of 1 -methyl-1,2-dihydronaphthalene $(0.50 \mathrm{mmol})$. The vial was capped and sealed with electrical tape and brought out of the glovebox and placed in an ice bath. Pinacol borane S79 
(HBPin, $0.065 \mathrm{~g}, 0.505 \mathrm{mmol}$ ) was then admitted to the reaction via syringe. After stirring at $0{ }^{\circ} \mathrm{C}$ for $5 \mathrm{~min}$, the reaction mixture was quenched by exposure to air. Purification by flash column chromatography (silica gel; gradient $0 \%$ to $5 \%$ to $10 \%$ ethyl acetate in hexanes) yielded $0.115 \mathrm{~g}$ $(0.422 \mathrm{mmol}, 84 \%)$ of the product as a colorless oil as a mixture of diastereomers and regioisomers. Ratio of 1 -substituted to 2 -substituted product was $2(2.6: 1 d r): 1(1.2: 1 d r)$ as determined by quantitative $\left\{{ }^{1} \mathrm{H}\right\}^{13} \mathrm{C}$ NMR. The ${ }^{1} \mathrm{H}$ NMR was not assigned due to overlapping isomer peaks. Due to the complex mixture of regio- and diastereomers, only select characteristic peaks in the ${ }^{13} \mathrm{C}$ NMR were assigned.

${ }^{13} \mathrm{C}\left\{{ }^{1} \mathrm{H}\right\}$ NMR $\left(101 \mathrm{MHz}, \mathrm{CDCl}_{3}, 23{ }^{\circ} \mathrm{C}\right): \delta 142.2$ (2-BPin tetralin $\left.C\right), 141.8$ (2-BPin tetralin $\left.C\right)$, 141.72 (1-BPin tetralin C), 141.70 (1-BPin tetralin C), 137.5, 137.44, 137.43, 137.1, 129.3, $129.2,128.9,128.8,128.4,128.2,127.4,127.0,125.6,125.5,125.34,125.29,125.26,125.24$, 125.0, 124.9, 83.29 (1-BPin C), 83.28 (1-BPin $C$ ), 83.2 (2-BPin C), 83.1 (2-BPin C), 34.7, 33.7, $32.7,32.4,32.0,31.7,31.6,30.94,30.90,30.7,24.84,24.82,24.81,24.78,24.73,24.71,24.65$, 23.8, 23.1, 23.0, 22.2, 21.8, 21.6.

${ }^{11}$ B NMR (96 MHz, $\left.\mathrm{CDCl}_{3}\right): \delta 33.74$.

HRMS (ESI+) $m / z$ calculated for $\mathrm{C}_{17} \mathrm{H}_{25} \mathrm{BO}_{2}[\mathrm{M}]^{+} 272.1948$, found $m / z 272.1984$.<smiles>Brc1ccccc1CC1CCc2ccccc2C1</smiles>

(8f). Prepared according to the general procedure with the following modification. A $4 \mathrm{~mL}$ scintillation vial was charged in the glove box with $0.002 \mathrm{mg}$ (0.005 mmol, $1 \mathrm{~mol} \%$ ) [Co]-1 and a magnetic stir bar. Toluene (1 mL) was then added followed by $0.065 \mathrm{mg}$ of 1,2 -dihydronaphthalene $(0.50 \mathrm{mmol})$. The vial was capped and sealed with electrical tape and brought out of the glovebox and placed in an ice bath. Pinacol borane (HBPin, $0.065 \mathrm{~g}, 0.505 \mathrm{mmol}$ ) was then admitted to the reaction via syringe. After stirring at $0{ }^{\circ} \mathrm{C}$ S80 
for $5 \mathrm{~min}$, the reaction mixture was quenched by exposure to air. Purification by flash column chromatography (silica gel; gradient $0 \%$ to $5 \%$ to $10 \%$ ethyl acetate in hexanes) yielded $0.125 \mathrm{~g}$ $(0.484 \mathrm{mmol}, 97 \%)$ of the product as a colorless oil. Ratio of 1 -substituted to 2 -substituted product was 2.8:1 as determined by quantitative $\left\{{ }^{1} \mathrm{H}\right\}{ }^{13} \mathrm{C}$ NMR.<smiles>C(=C1CCCc2ccccc21)c1ccccc1</smiles>

4,4,5,5-tetramethyl-2-(1,2,3,4-tetrahydronaphthalen-1-yl)-1,3,2-

dioxaborolane. The ${ }^{1} \mathrm{H}$ NMR was not assigned due to overlapping isomer peaks.

${ }^{13} \mathrm{C}\left\{{ }^{1} \mathrm{H}\right\}$ NMR $\left(101 \mathrm{MHz}, \mathrm{CDCl}_{3}, 23{ }^{\circ} \mathrm{C}\right): \delta 137.7$ (tetralin $\left.C\right), 136.7$ (tetralin $\left.C\right), 129.39$ (tetralin $\mathrm{CH}$ ), 129.37 (tetralin $\mathrm{CH}$ ), 125.35 (tetralin $\mathrm{CH}$ ), 124.8 (tetralin $\mathrm{CH}$ ), 83.3 (BPin $\mathrm{C}$ ), 29.8 (tetralin $\mathrm{CH}_{2}$ ), 25.2 (tetralin $\mathrm{CHBPin}$ ), $24.76\left(\mathrm{BPin} \mathrm{CH}_{3}\right), 24.72\left(\mathrm{BPin} \mathrm{CH}_{3}\right), 22.7$ (tetralin $\left.\mathrm{CH}_{2}\right)$.

${ }^{11} \mathrm{~B}$ NMR $\left(96 \mathrm{MHz}, \mathrm{CDCl}_{3}\right): \delta 33.61$. These spectroscopic data correspond to reported values. ${ }^{55}$<smiles>CC1CCc2ccccc2C1</smiles>

\section{4,4,5,5-tetramethyl-2-(1,2,3,4-tetrahydronaphthalen-2-yl)-1,3,2-}

dioxaborolane. The ${ }^{1} \mathrm{H}$ NMR was not assigned due to overlapping isomer peaks.

${ }^{13} \mathrm{C}\left\{{ }^{1} \mathrm{H}\right\}$ NMR $\left(101 \mathrm{MHz}, \mathrm{CDCl}_{3}, 23{ }^{\circ} \mathrm{C}\right): \delta 137.5$ (tetralin $\left.C\right), 137.0$ (tetralin $\left.C\right), 129.2$ (tetralin $\mathrm{CH}$ ), 129.0 (tetralin $\mathrm{CH}$ ), 125.37 (tetralin $\mathrm{CH}$ ), 124.8 (tetralin $\mathrm{CH}$ ), 83.2 (BPin $\mathrm{C}$ ), 30.7 (tetralin $\mathrm{CH}_{2}$ ), 29.8 (tetralin $\left.\mathrm{CHBPin}\right), 24.9\left(\mathrm{BPin} \mathrm{CH}_{3}\right), 24.8\left(\mathrm{BPin} \mathrm{CH}_{3}\right), 22.7$ (tetralin $\mathrm{CH}_{2}$ ).

${ }^{11} \mathrm{~B}$ NMR $\left(96 \mathrm{MHz}, \mathrm{CDCl}_{3}\right): \delta 33.61$. These spectroscopic data correspond to reported values. ${ }^{56}$ 


\section{DFT Calculations.}

\section{DFT Input File Example}

! UKS B3LYP RIJCOSX def2-SVP def2/J Normalprint SlowConv TightSCF Opt Pal8 UCO Numfreq Grid4 Nofinalgrid

\%basis NewGTO 27 "def2-TZVP(-f)" end NewGTO 7 "def2-TZVP(-f)" end

NewAuxGTO 27 "def2/J" end

NewAuxGTO 7 "def2/J" end

end

\%SCF Maxiter 5000

TolE 1e-7

TolErr 1e-6

End

${ }^{*}$ xyz 0 \#

xyz coordinates

$\star$

\%FREQ RESTART TRUE

CENTRALDIFF TRUE

INCREMENT 0.01

END

\section{Energies and Coordinates}

Table S4. Calculated Gibbs free energies of (Terpy)CoH at different spin states.

Spin State Input Calculated Gibbs Free Energy (Eh)

$\begin{array}{ll}S=1(\mathrm{UKS}) & -2124.82533856 \\ S=1(\mathrm{UKS}, \mathrm{BS} 3,1) & -2124.82533748 \\ S=0(\mathrm{UKS}, \mathrm{BS} 1,1) & -2124.82379544 \\ S=0(\mathrm{RKS}) & -2124.80947905\end{array}$


a.
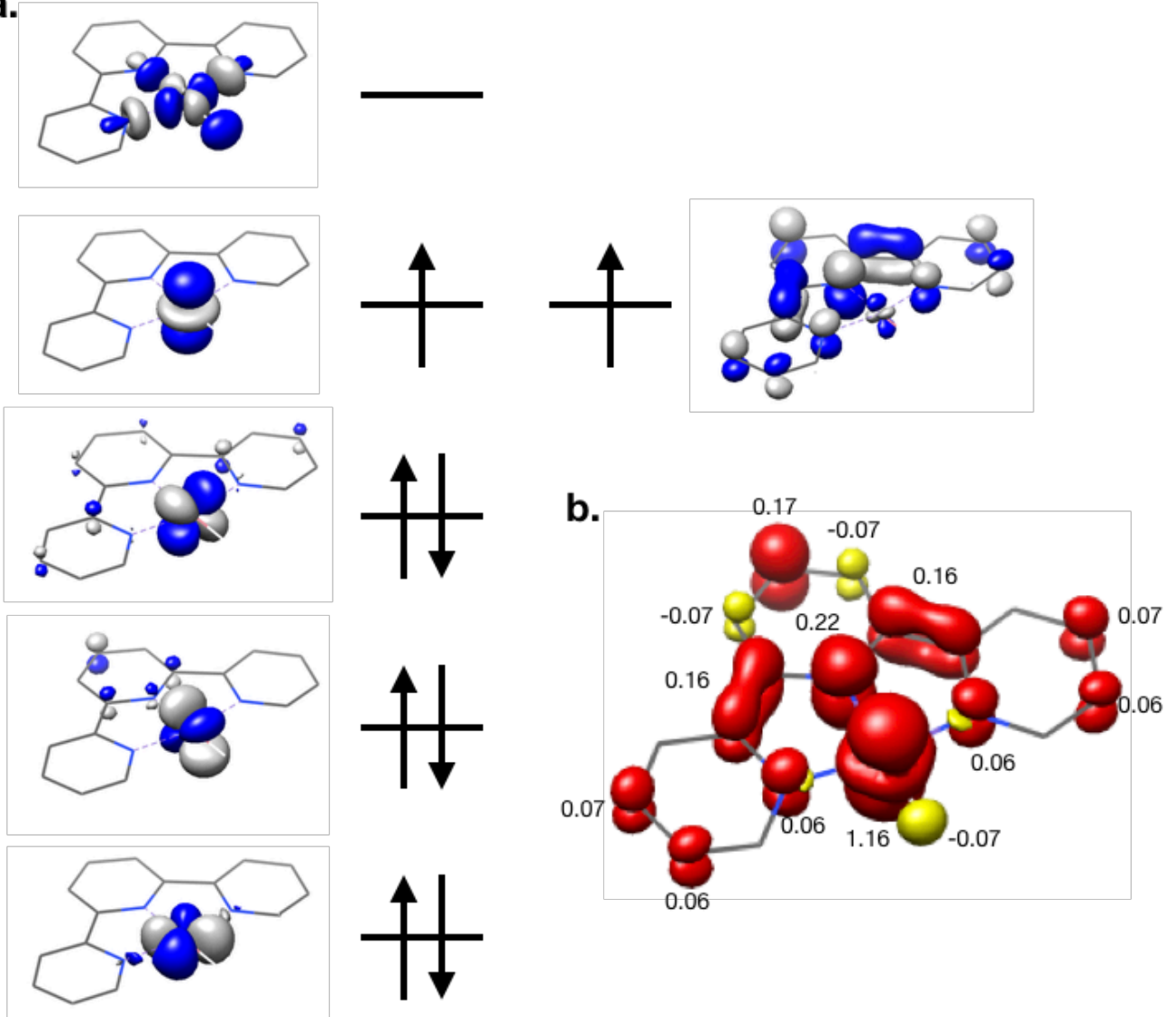

Figure S21. (a) DFT-computed qualitative molecular orbital diagram for $S=1$ solution of [(Terpy)CoH]. (b) DFT computed spin density plot for $S=1$ solution of [(Terpy)CoH]. 
a.
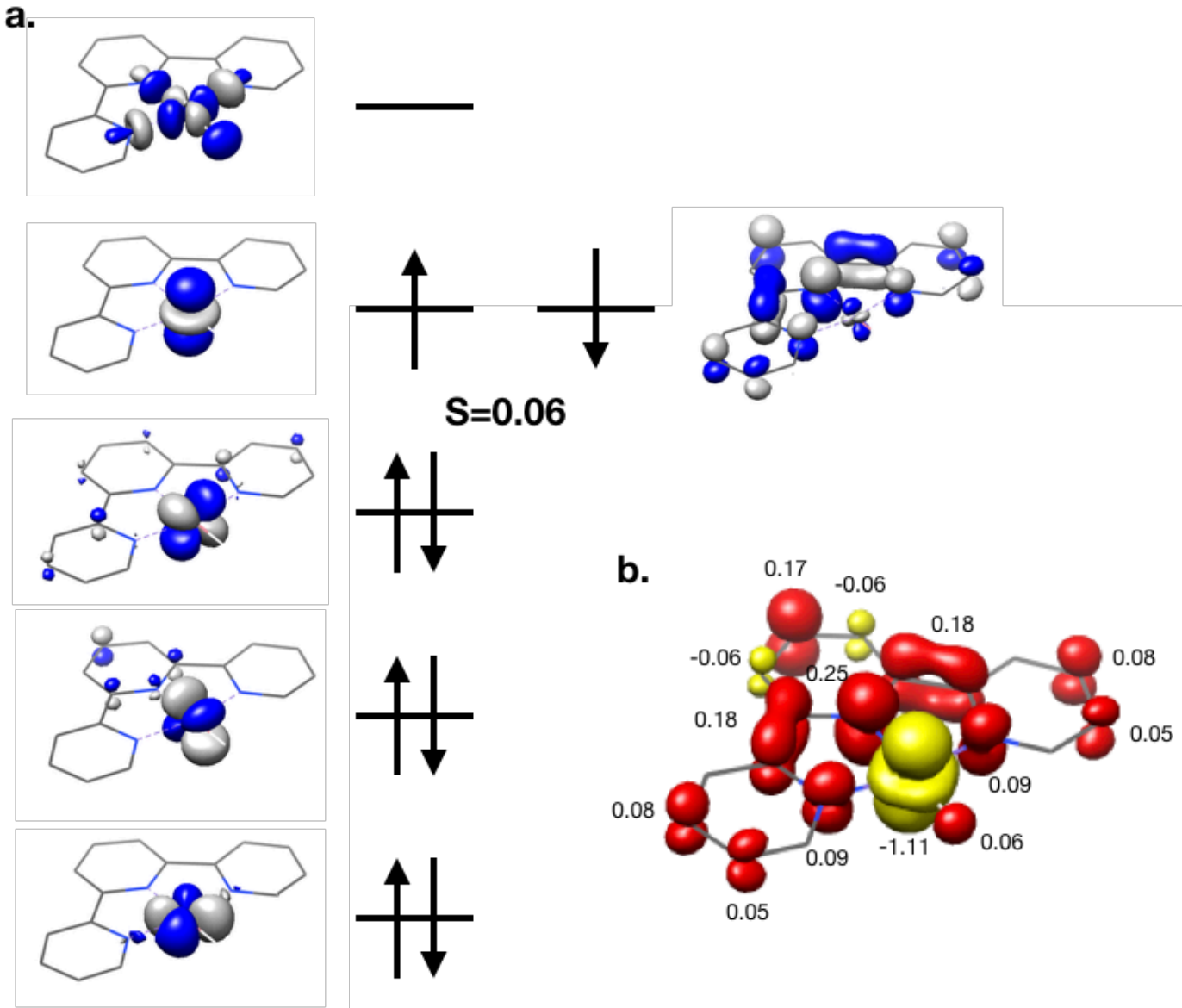

Figure S22. (a) DFT-computed qualitative molecular orbital diagram for $S=0(B S 1,1)$ solution of [(Terpy)CoH]. (b) DFT computed spin density plot for $S=0$ (BS 1,1) solution of [(Terpy)CoH].

Coordinates from Geometry Optimization

\section{(Terpy) CoH}
C 0.17514344587517
H 0.28477706358178
C 0.11947709009894
H 0.18254423074048
C -0.01197192412479
H -0.05321698066365
C -0.09287225575052
H -0.20223838501426
C -0.04728307688838
C -0.16100159187377

2.78815395490726

2.33446575025895

4.16378079550789

4.81940143689116

4.68229993709011

5.76036578108910

3.79875711258436

4.16863696442409

2.41377855392074

1.38552866037853
$-1.00599168569596$

$-1.99134408825695$

$-0.83592614748150$

$-1.70581502582373$

0.46843243703272

0.64193219715821

1.53439153478993

2.55544154504760

1.30321853478863

2.32682802093764

S84 


$\begin{array}{llll}\text { C } & -0.34645275212919 & 1.53473393110030 & 3.70107118331377 \\ \text { H } & -0.41623573103130 & 2.52570782577597 & 4.15319690141811 \\ \text { C } & -0.45573994616051 & 0.38441286162158 & 4.50134032032914 \\ \text { H } & -0.60771994192518 & 0.48593029764453 & 5.57791895465946 \\ \text { C } & -0.38964608180095 & -0.89400501088390 & 3.92029109814583 \\ \text { H } & -0.49156195543340 & -1.78659095643106 & 4.54063357862417 \\ \text { C } & -0.20446610815522 & -0.99931668725966 & 2.54201539387270 \\ \text { C } & -0.12559174616575 & -2.19744313975428 & 1.71945964782641 \\ \text { C } & -0.22855020277674 & -3.51749622331452 & 2.19001177184076 \\ \text { H } & -0.37402111270187 & -3.69677384135469 & 3.25714724179970 \\ \text { C } & -0.15725827942492 & -4.57913485280186 & 1.29933654283169 \\ \text { H } & -0.24074936796024 & -5.60799566178902 & 1.65794450309214 \\ \text { C } & 0.01977281021701 & -4.30345160906940 & -0.07110885238809 \\ \text { H } & 0.08019776915670 & -5.10534919728233 & -0.80886698164229 \\ \text { C } & 0.11997444051160 & -2.98172810954828 & -0.48154819300962 \\ \text { H } & 0.25948087823860 & -2.71239252254070 & -1.52917611398467 \\ \text { N } & 0.10033225075109 & 1.91519231814205 & 0.01773690345901 \\ \text { N } & -0.09045377980347 & 0.13374175480679 & 1.79201602177044 \\ \text { N } & 0.05413586256069 & -1.93908353384589 & 0.36925895912615 \\ \text { Co } & 0.14527618616846 & -0.03791458676340 & -0.08616051143678 \\ \text { H } & 0.33364919188360 & -0.17642200350440 & -1.60775569214460\end{array}$




\section{NMR Spectra.}

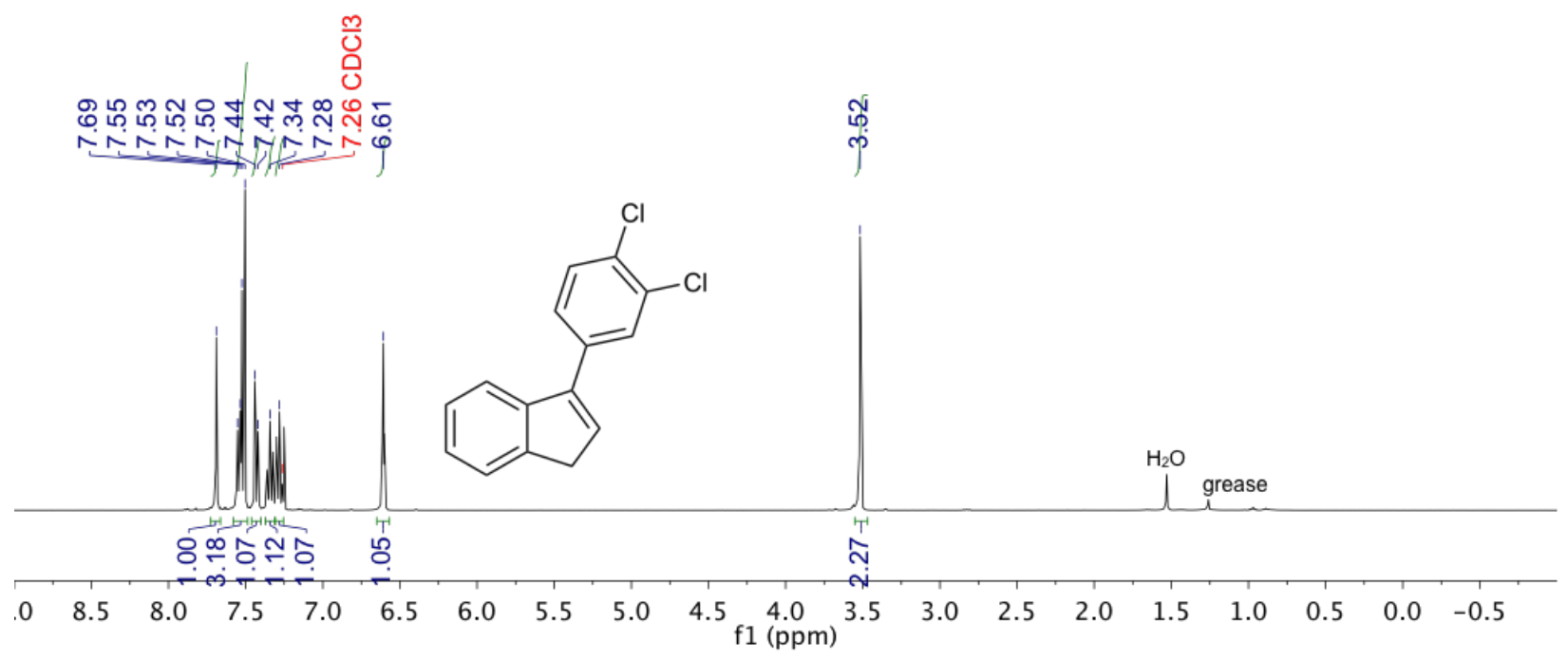

${ }^{1} \mathrm{H}$ NMR $\left(500 \mathrm{MHz}, \mathrm{CDCl}_{3}, 23^{\circ} \mathrm{C}\right)$ spectrum of $1 \mathrm{k}$.
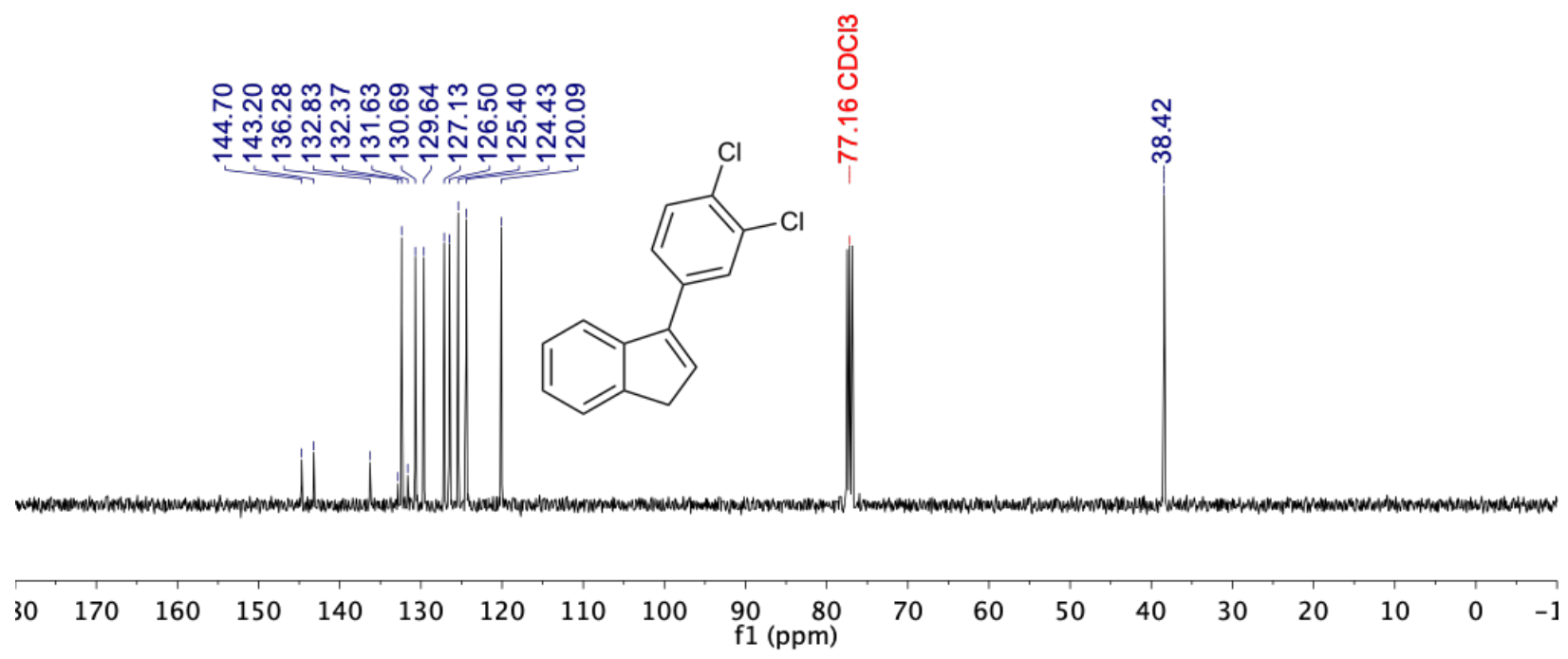

${ }^{13} \mathrm{C}$ NMR $\left(126 \mathrm{MHz}, \mathrm{CDCl}_{3}, 23^{\circ} \mathrm{C}\right)$ spectrum of $1 \mathrm{k}$. 


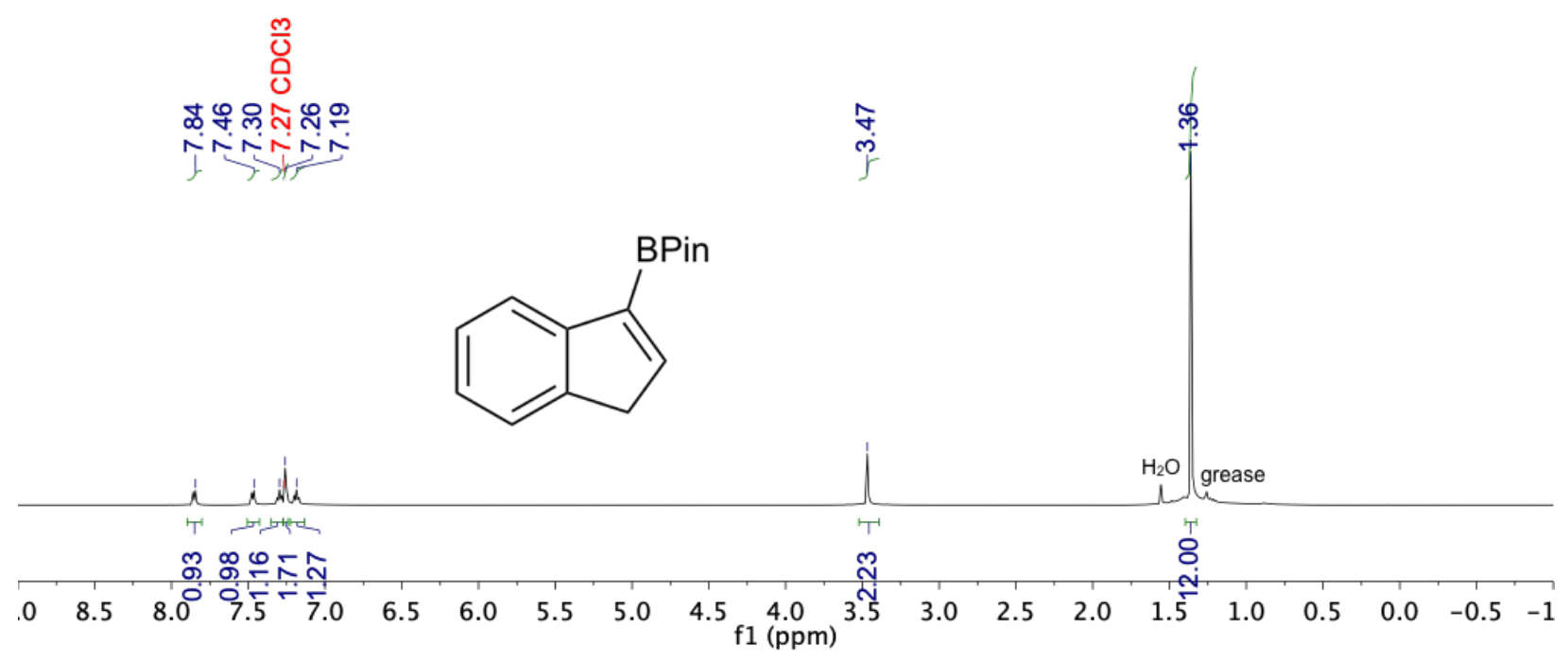

${ }^{1} \mathrm{H}$ NMR $\left(500 \mathrm{MHz}, \mathrm{CDCl}_{3}, 23^{\circ} \mathrm{C}\right)$ spectrum of $1 \mathrm{n}$.

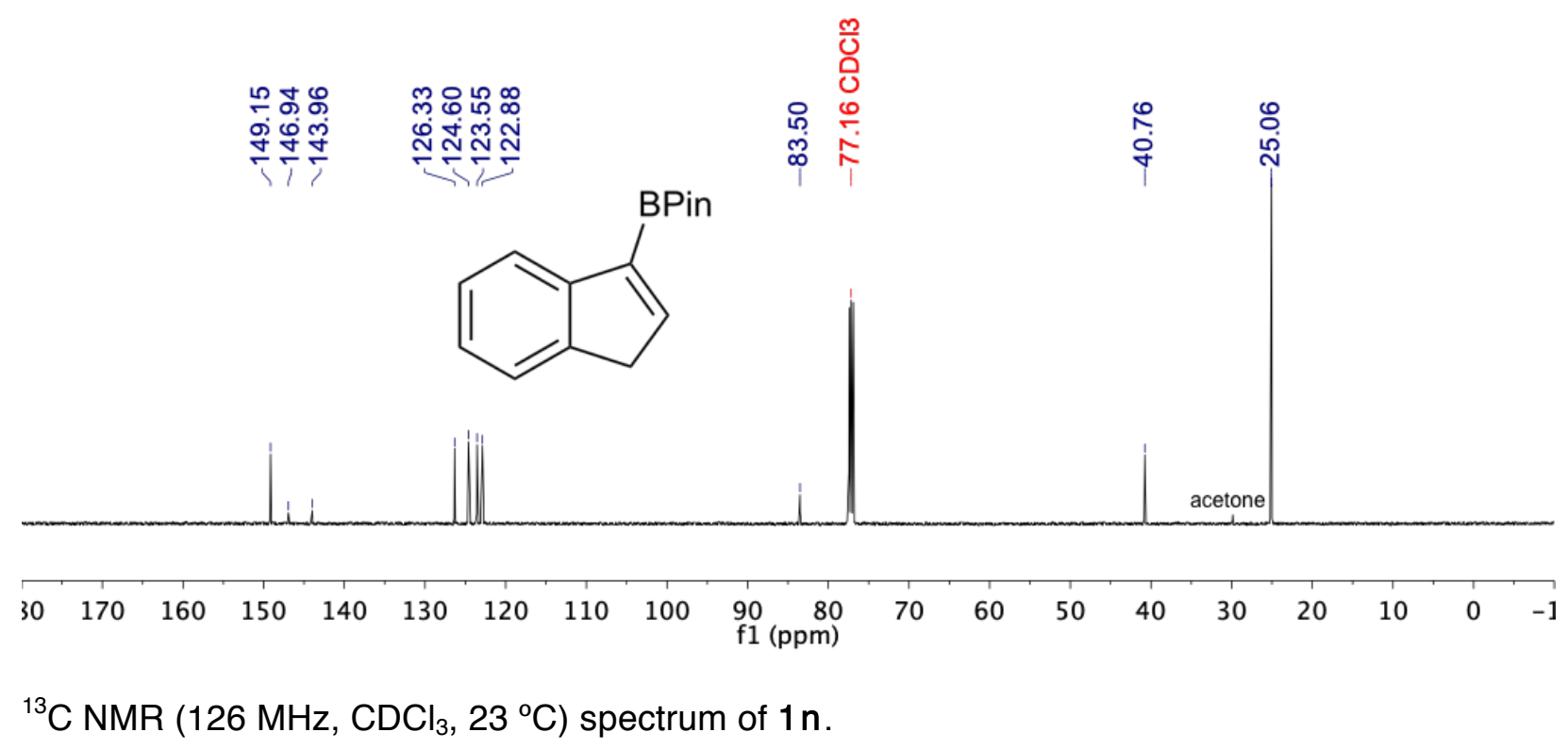




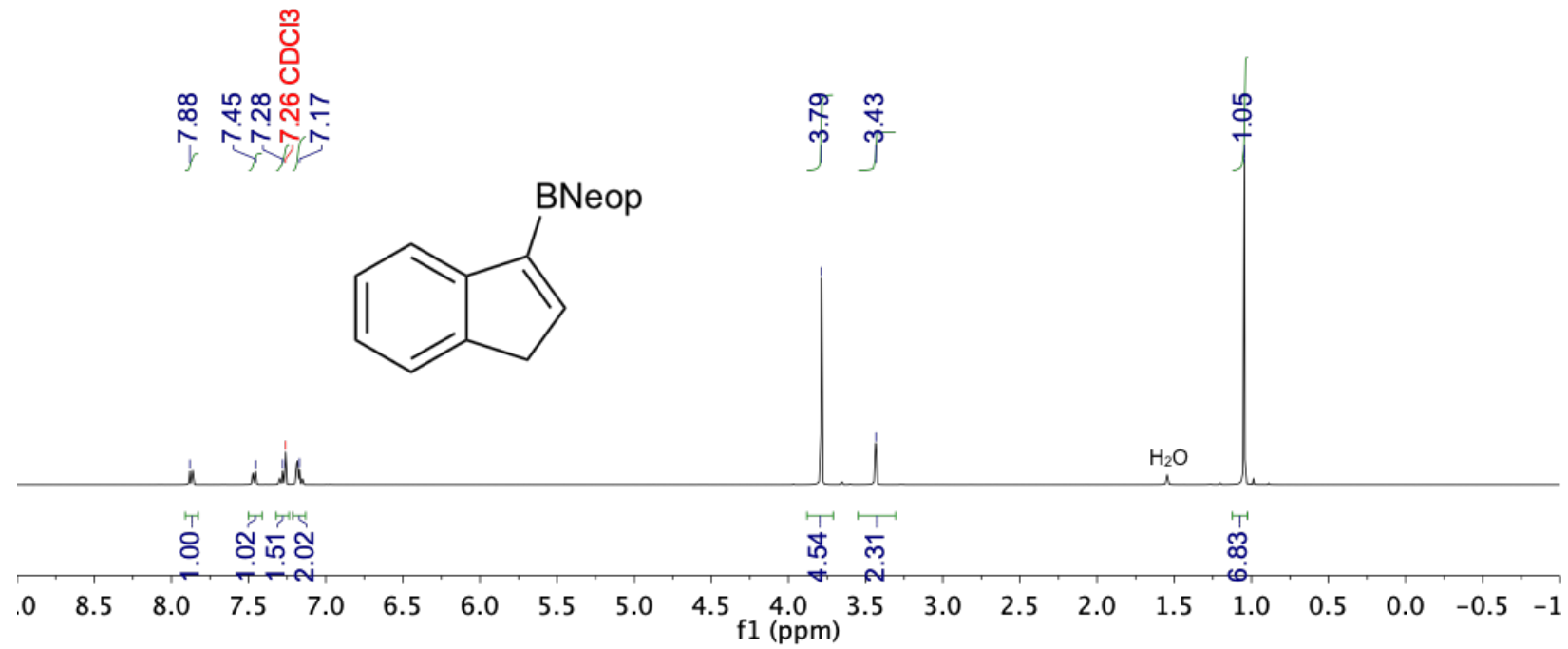

${ }^{1} \mathrm{H}$ NMR $\left(500 \mathrm{MHz}, \mathrm{CDCl}_{3}, 23^{\circ} \mathrm{C}\right)$ spectrum of 10.

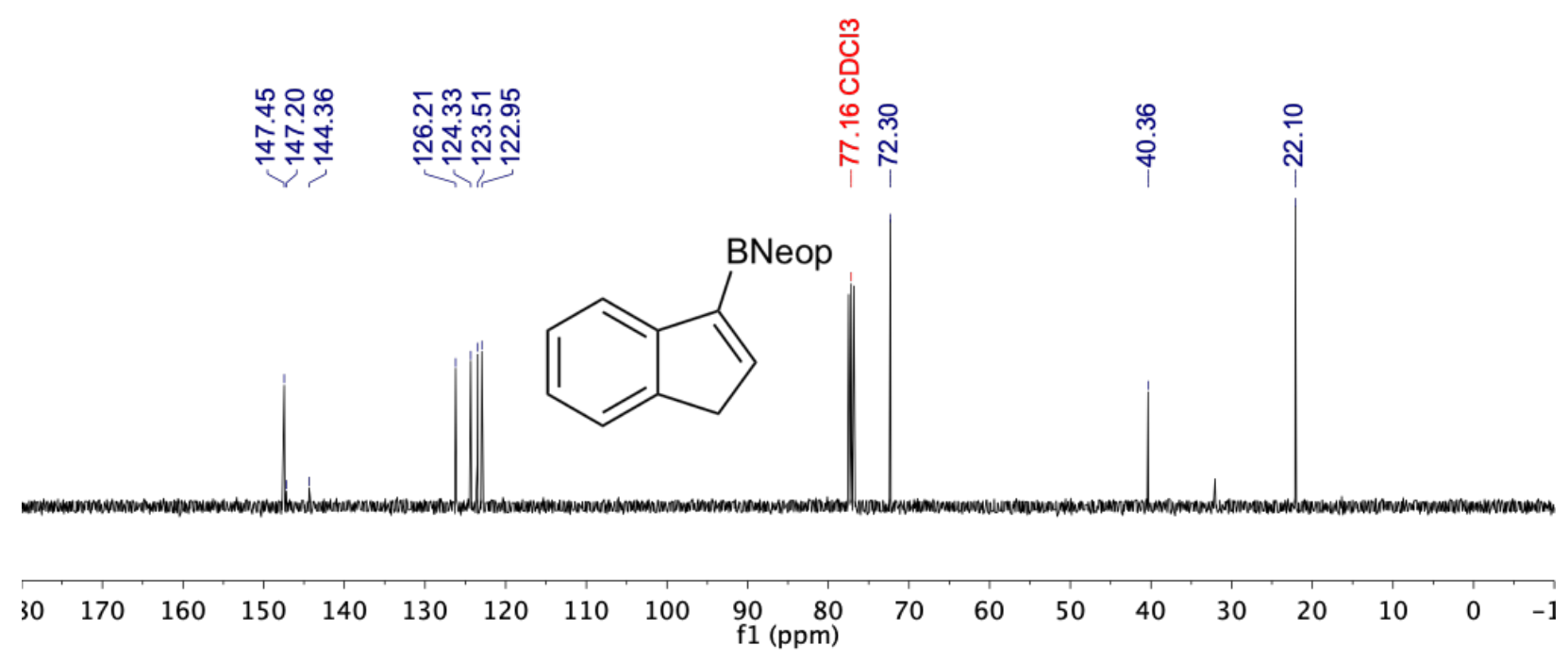

${ }^{13} \mathrm{C}$ NMR $\left(126 \mathrm{MHz}, \mathrm{CDCl}_{3}, 23^{\circ} \mathrm{C}\right)$ spectrum of 10. 


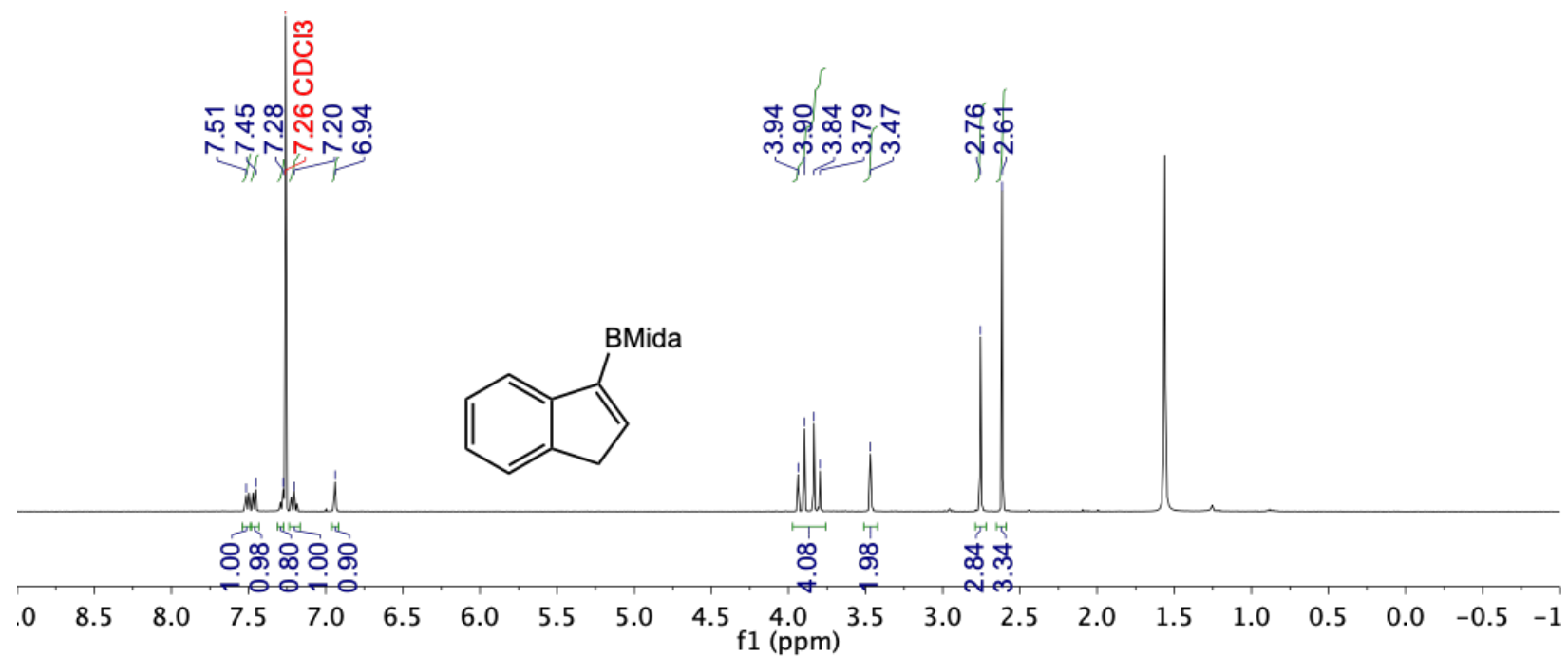

${ }^{1} \mathrm{H}$ NMR $\left(500 \mathrm{MHz}, \mathrm{CDCl}_{3}, 23^{\circ} \mathrm{C}\right)$ spectrum of $1 \mathrm{p}$. *Peak corresponds to $\mathrm{H}_{2} \mathrm{O}$.

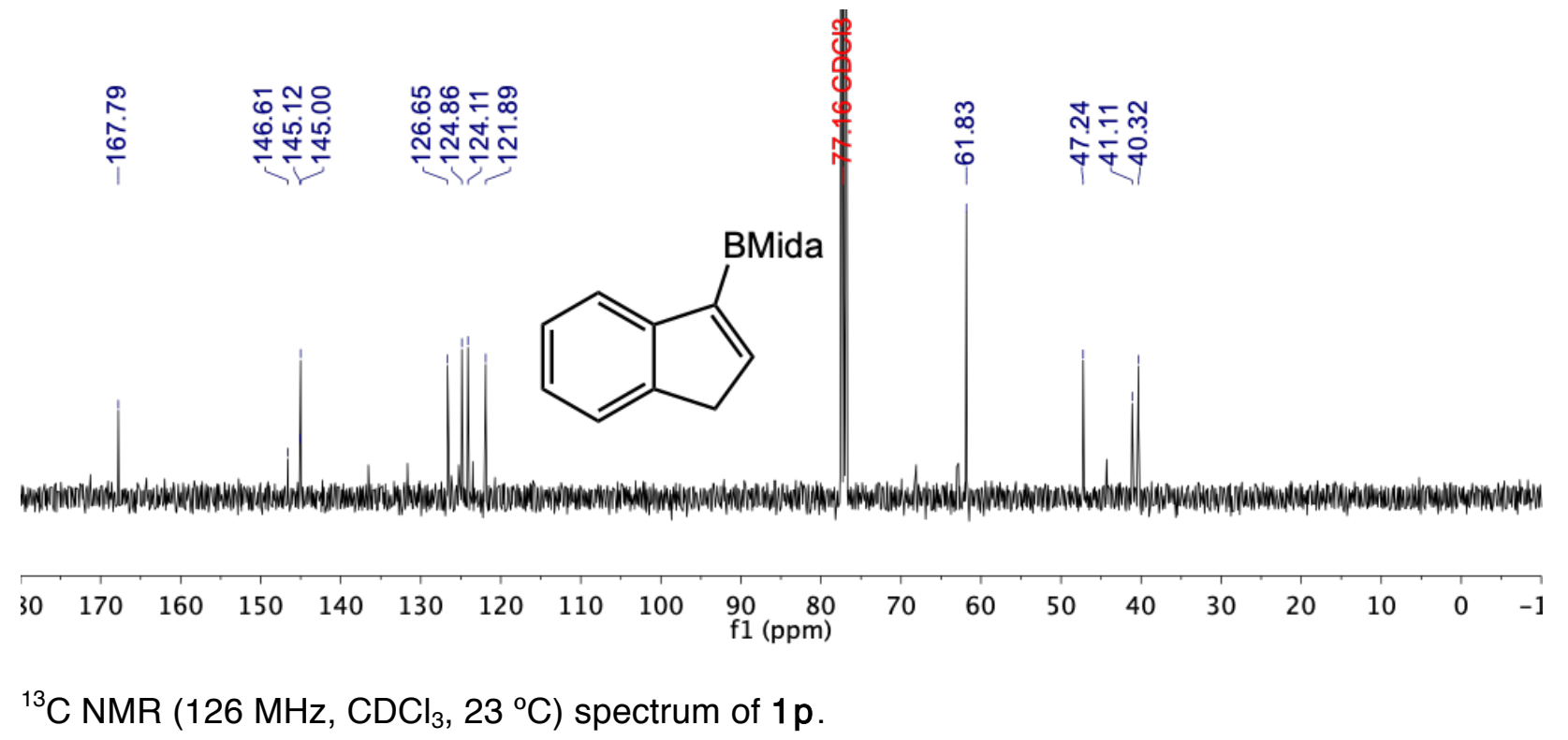




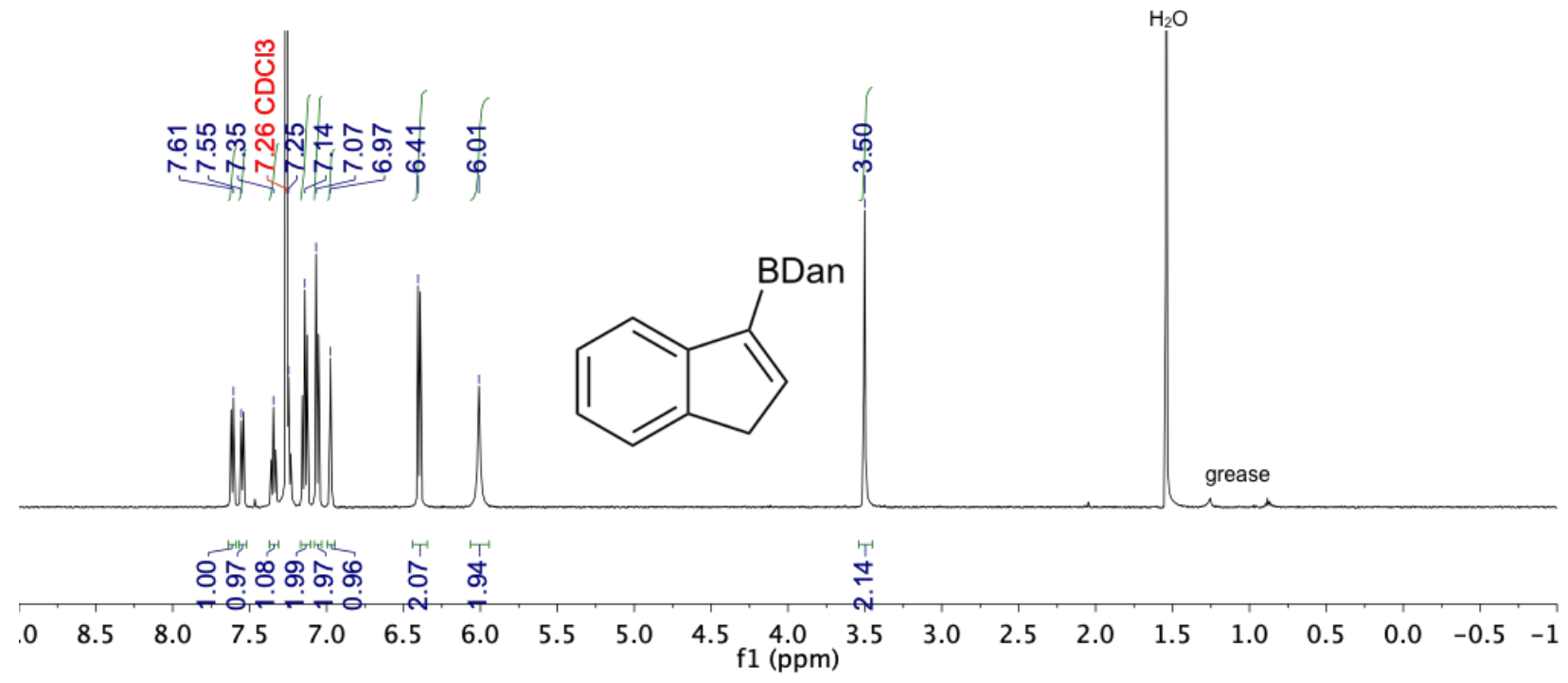

${ }^{1} \mathrm{H}$ NMR $\left(500 \mathrm{MHz}, \mathrm{CDCl}_{3}, 23^{\circ} \mathrm{C}\right)$ spectrum of $1 \mathrm{q}$.

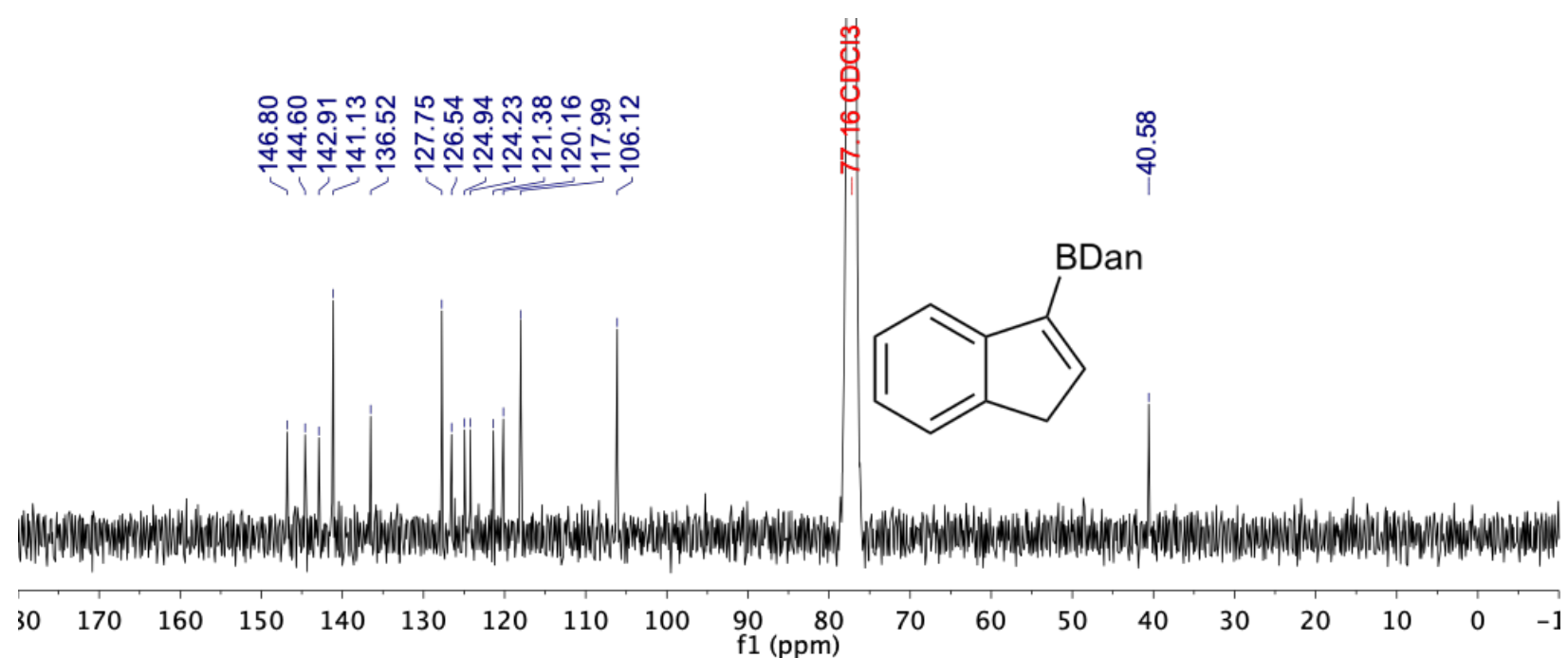

${ }^{13} \mathrm{C}$ NMR $\left(126 \mathrm{MHz}, \mathrm{CDCl}_{3}, 23^{\circ} \mathrm{C}\right)$ spectrum of $1 \mathrm{q}$. 


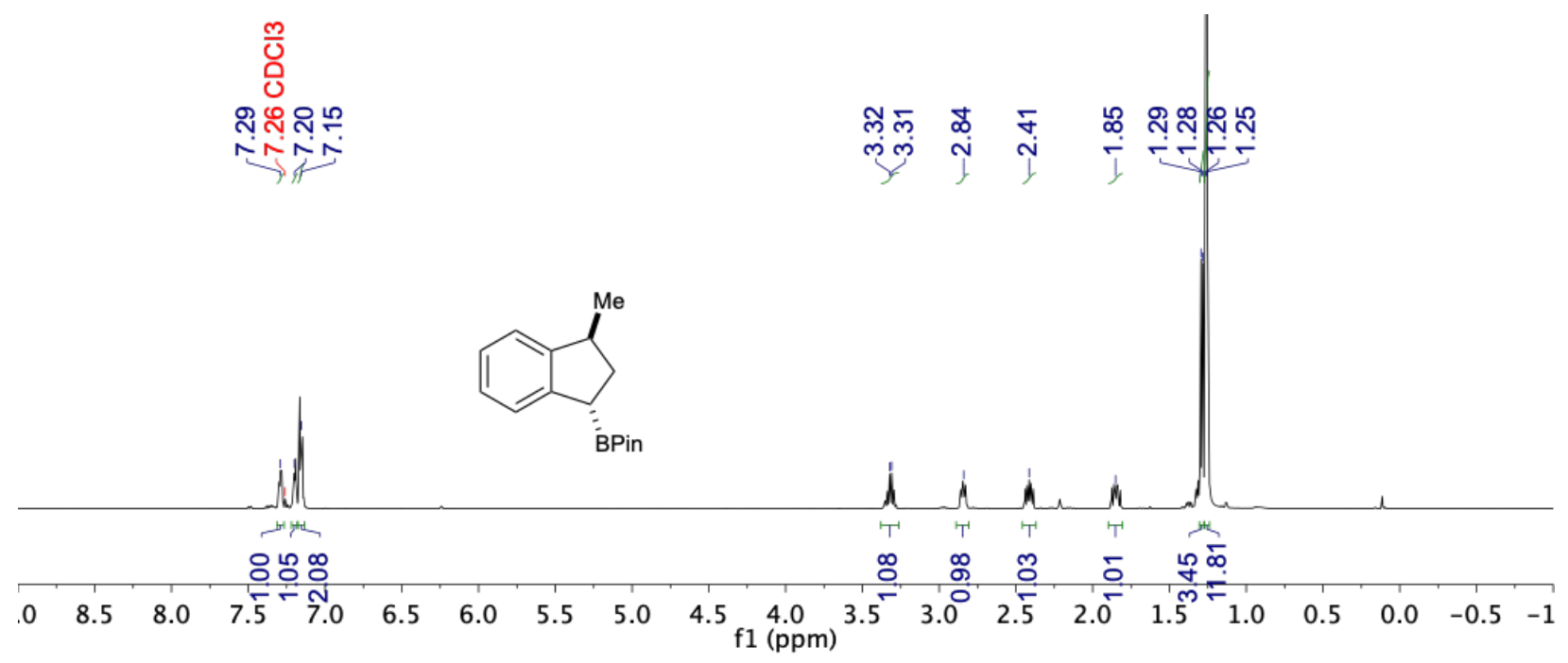

${ }^{1} \mathrm{H}$ NMR $\left(500 \mathrm{MHz}, \mathrm{CDCl}_{3}, 23^{\circ} \mathrm{C}\right)$ spectrum of $2 \mathrm{a}$.

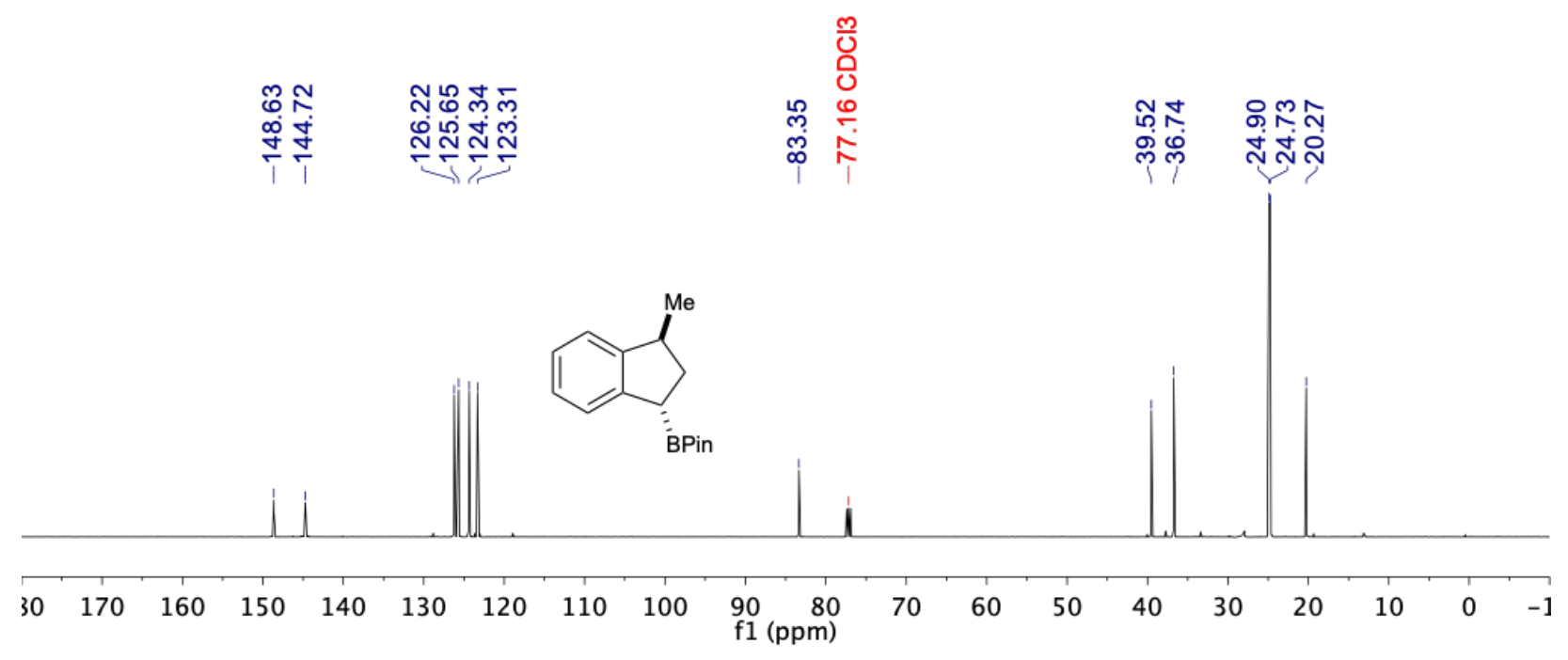

${ }^{13} \mathrm{C}$ NMR $\left(126 \mathrm{MHz}, \mathrm{CDCl}_{3}, 23^{\circ} \mathrm{C}\right)$ spectrum of $2 \mathbf{a}$. 


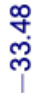

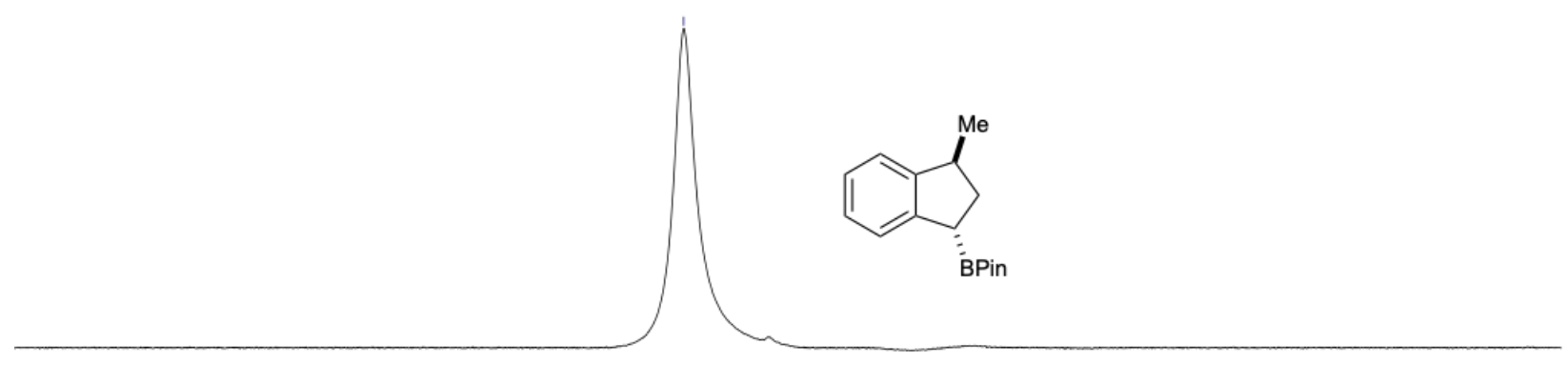

$\begin{array}{lllllllllllllllllll}110 & 100 & 90 & 80 & 70 & 60 & 50 & 40 & 30 \underset{\mathrm{f} 1 \underset{(\mathrm{ppm})}{20}}{20} & 10 & 0 & -10 & -20 & -30 & -40 & -50 & -60 & -70\end{array}$

${ }^{11} \mathrm{~B}$ NMR $\left(96 \mathrm{MHz}, \mathrm{CDCl}_{3}, 23^{\circ} \mathrm{C}\right)$ spectrum of $2 \mathrm{a}$.

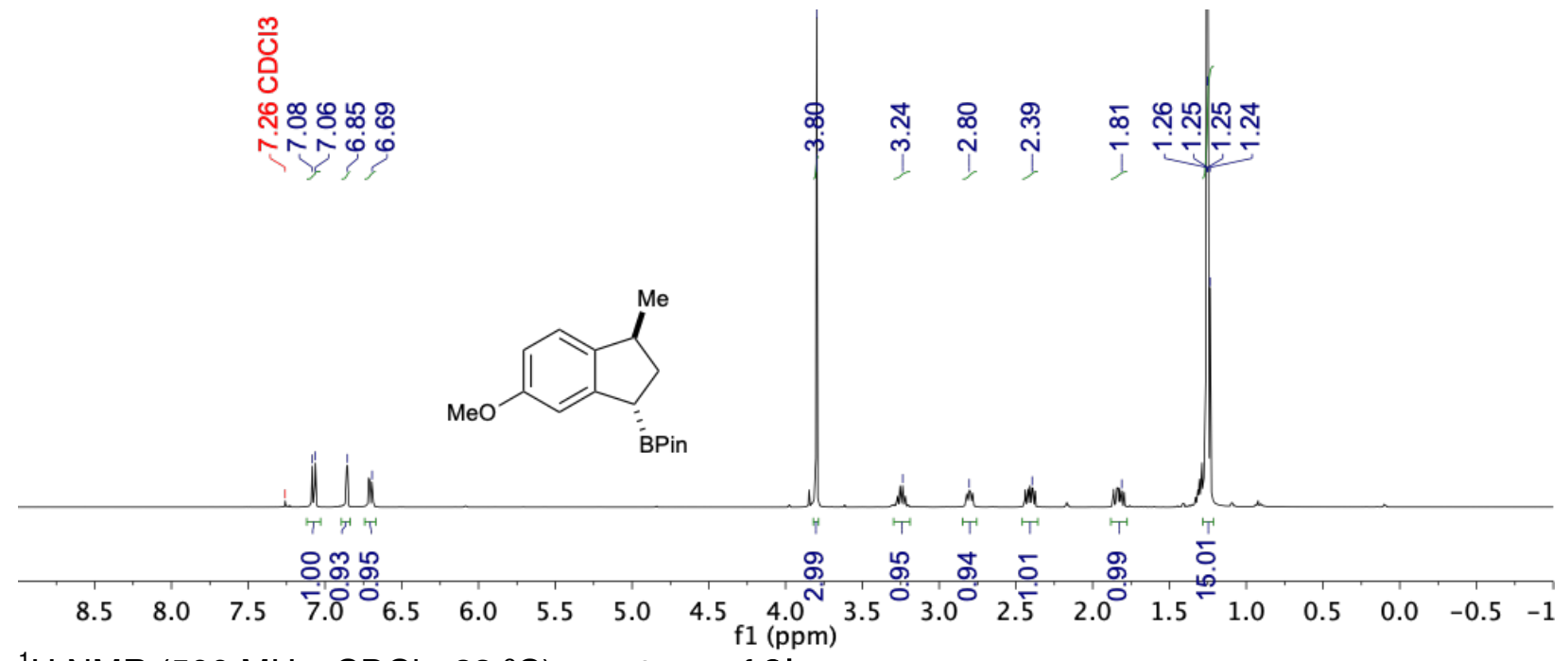

${ }^{1} \mathrm{H}$ NMR $\left(500 \mathrm{MHz}, \mathrm{CDCl}_{3}, 23^{\circ} \mathrm{C}\right)$ spectrum of $2 \mathrm{~b}$. 


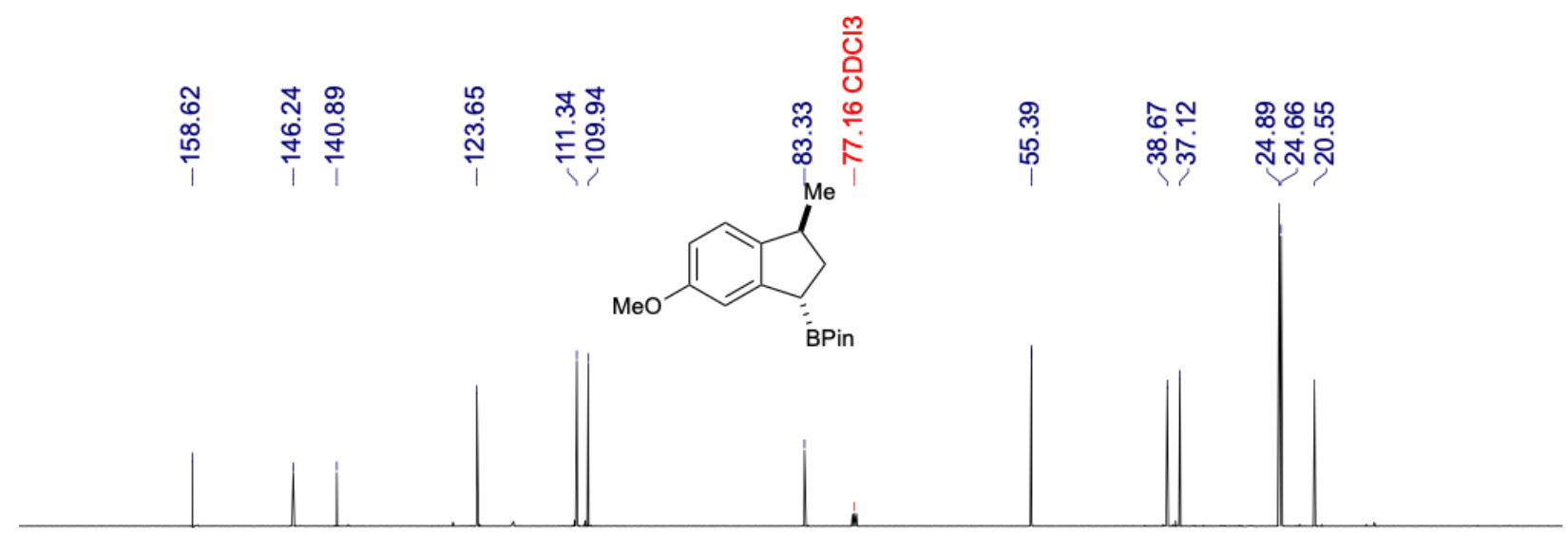

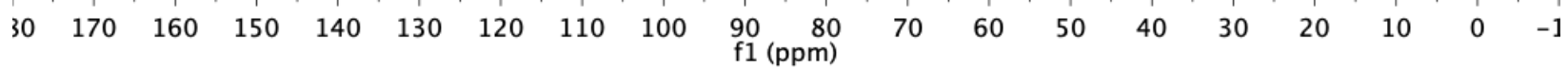
${ }^{13} \mathrm{C}$ NMR $\left(126 \mathrm{MHz}, \mathrm{CDCl}_{3}, 23^{\circ} \mathrm{C}\right)$ spectrum of $2 \mathrm{~b}$.

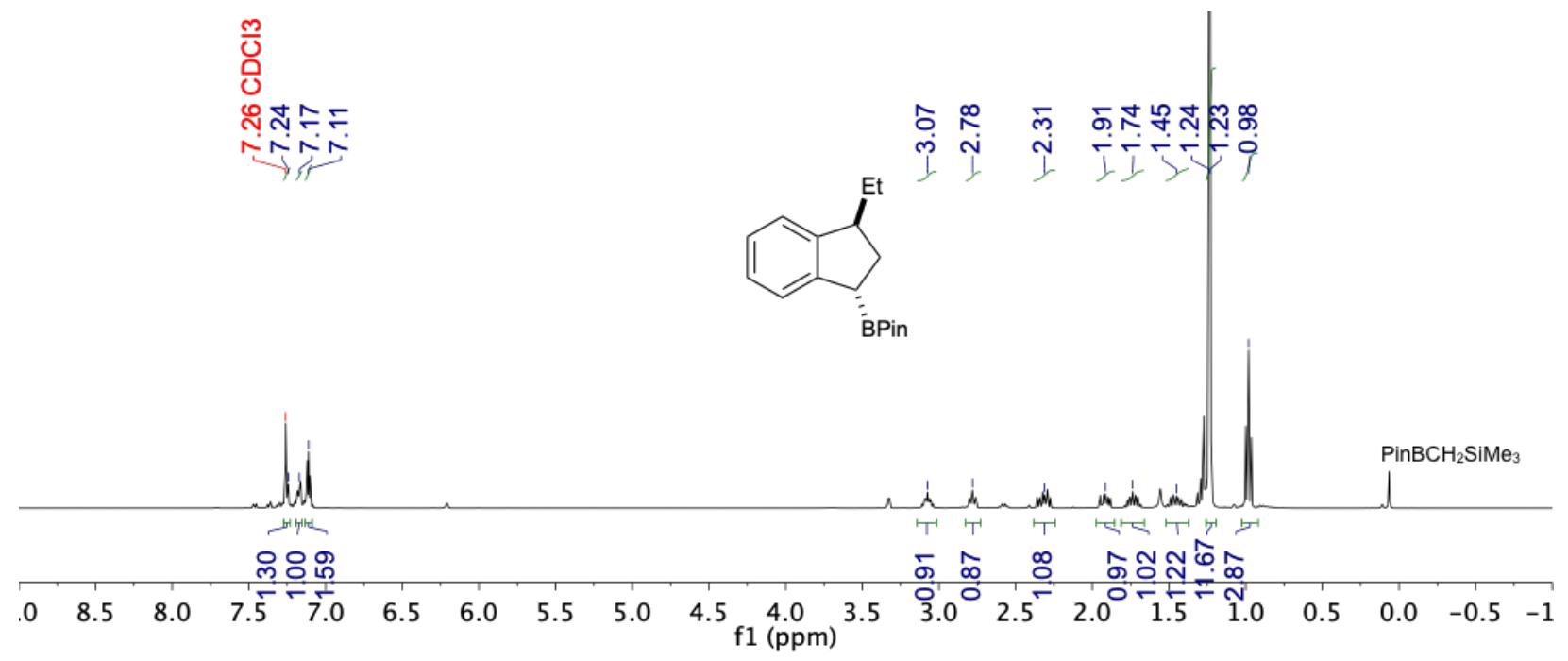

${ }^{1} \mathrm{H}$ NMR $\left(500 \mathrm{MHz}, \mathrm{CDCl}_{3}, 23^{\circ} \mathrm{C}\right)$ spectrum of $2 \mathrm{c}$. 


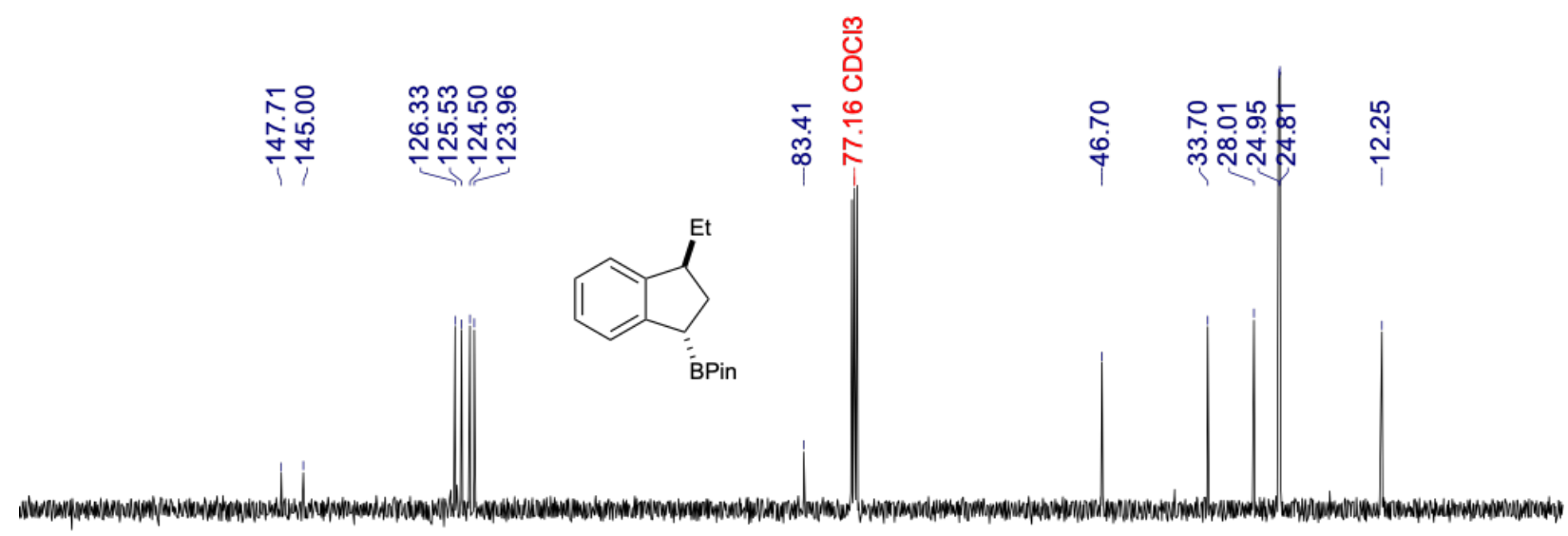

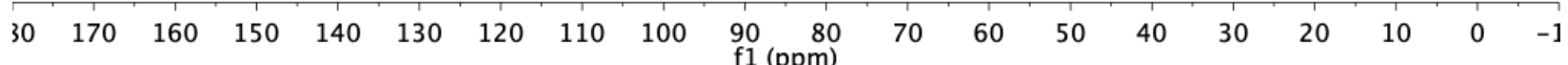

${ }^{13} \mathrm{C}$ NMR $\left(126 \mathrm{MHz}, \mathrm{CDCl}_{3}, 23^{\circ} \mathrm{C}\right)$ spectrum of $2 \mathrm{c}$.

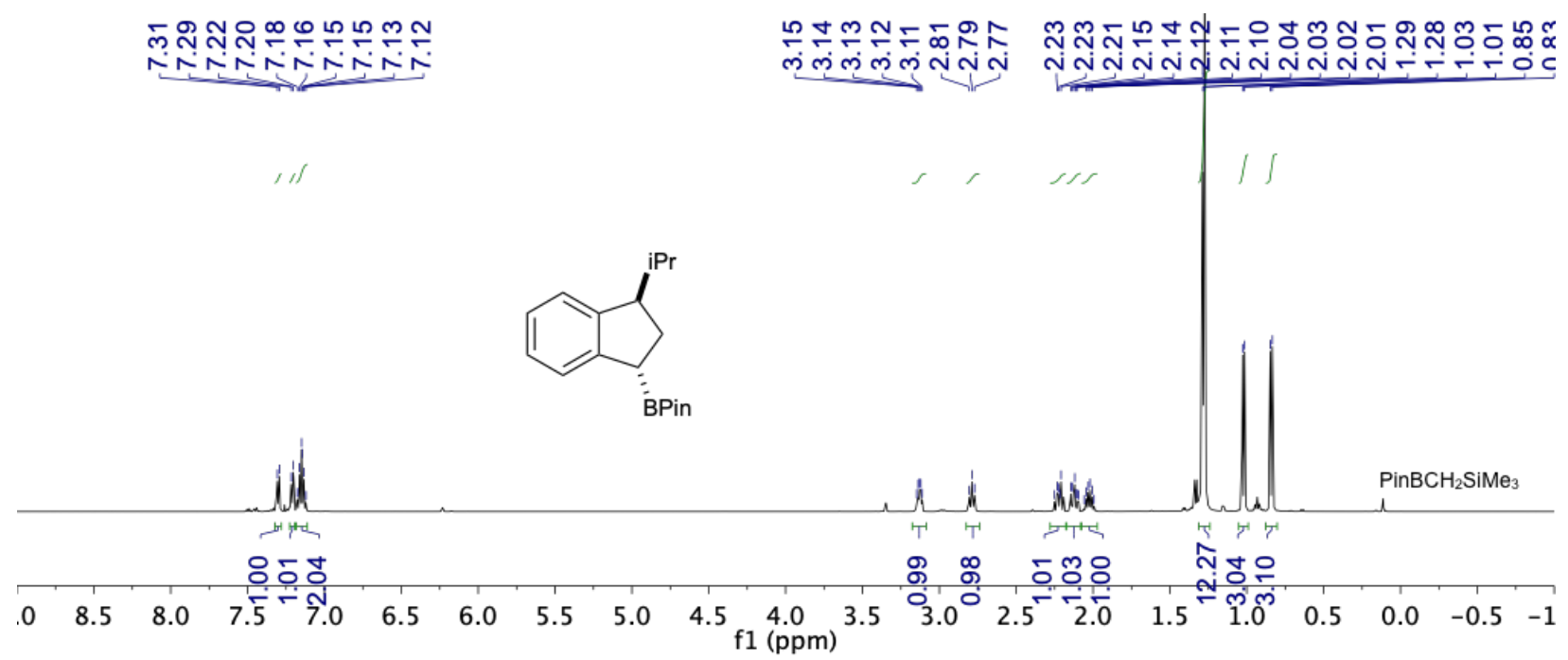

${ }^{1} \mathrm{H}$ NMR $\left(500 \mathrm{MHz}, \mathrm{CDCl}_{3}, 23^{\circ} \mathrm{C}\right)$ spectrum of $2 \mathrm{~d}$. 


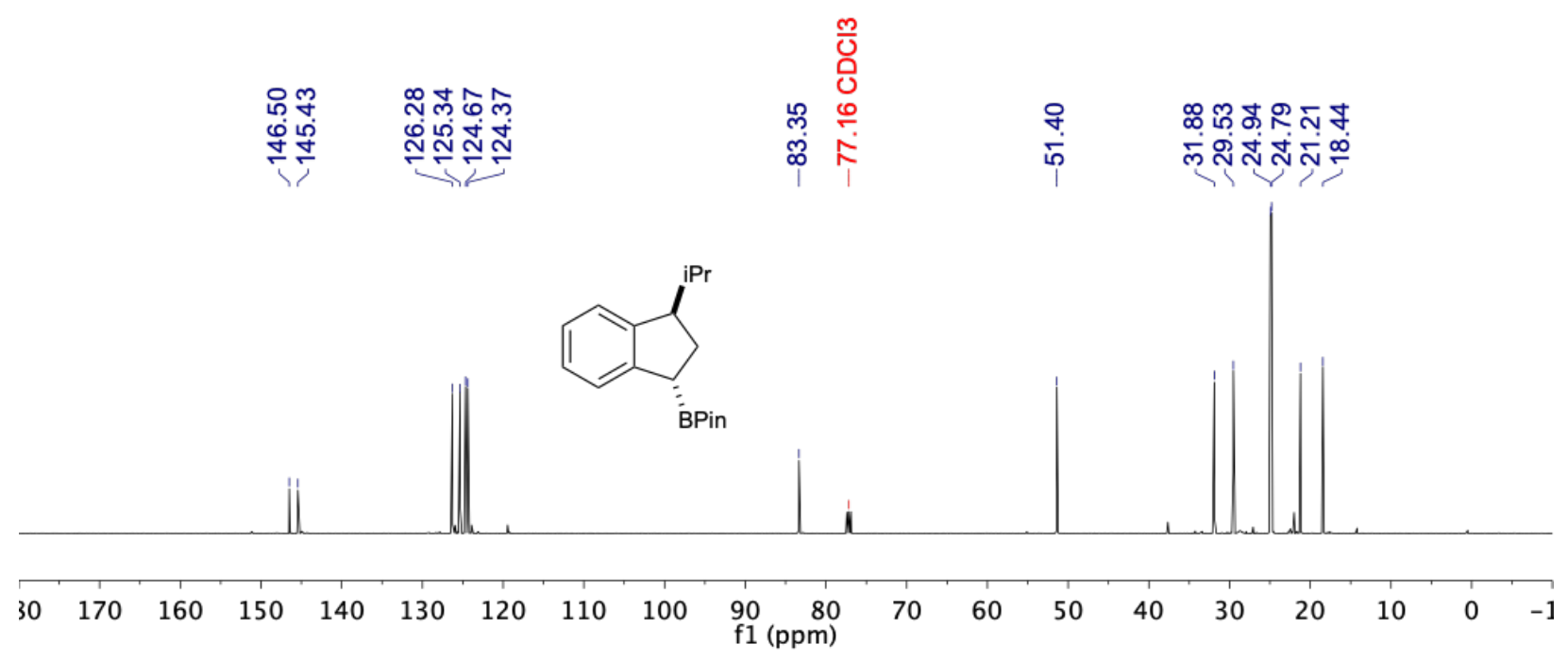

${ }^{13} \mathrm{C}$ NMR $\left(126 \mathrm{MHz}, \mathrm{CDCl}_{3}, 23^{\circ} \mathrm{C}\right)$ spectrum of $2 \mathrm{~d}$.

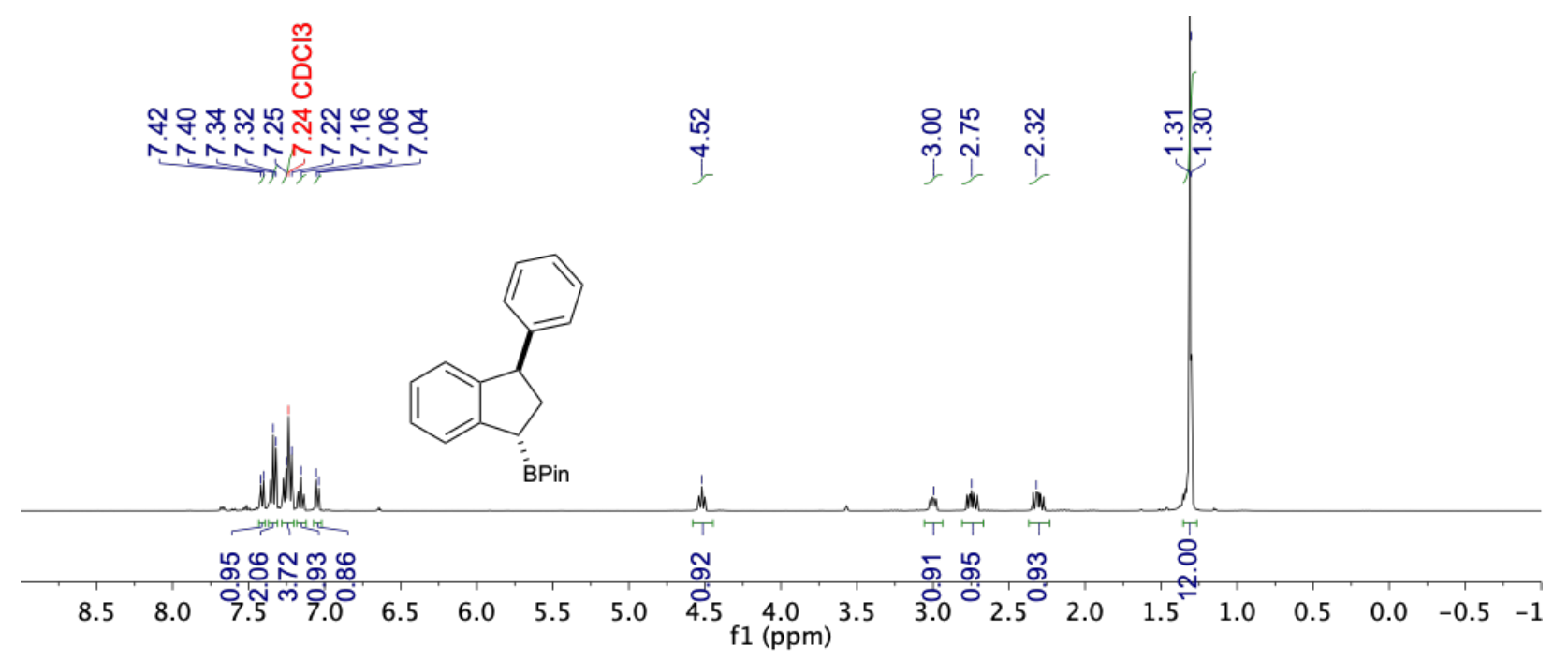

${ }^{1} \mathrm{H}$ NMR $\left(500 \mathrm{MHz}, \mathrm{CDCl}_{3}, 23^{\circ} \mathrm{C}\right)$ spectrum of $2 \mathrm{e}$. 


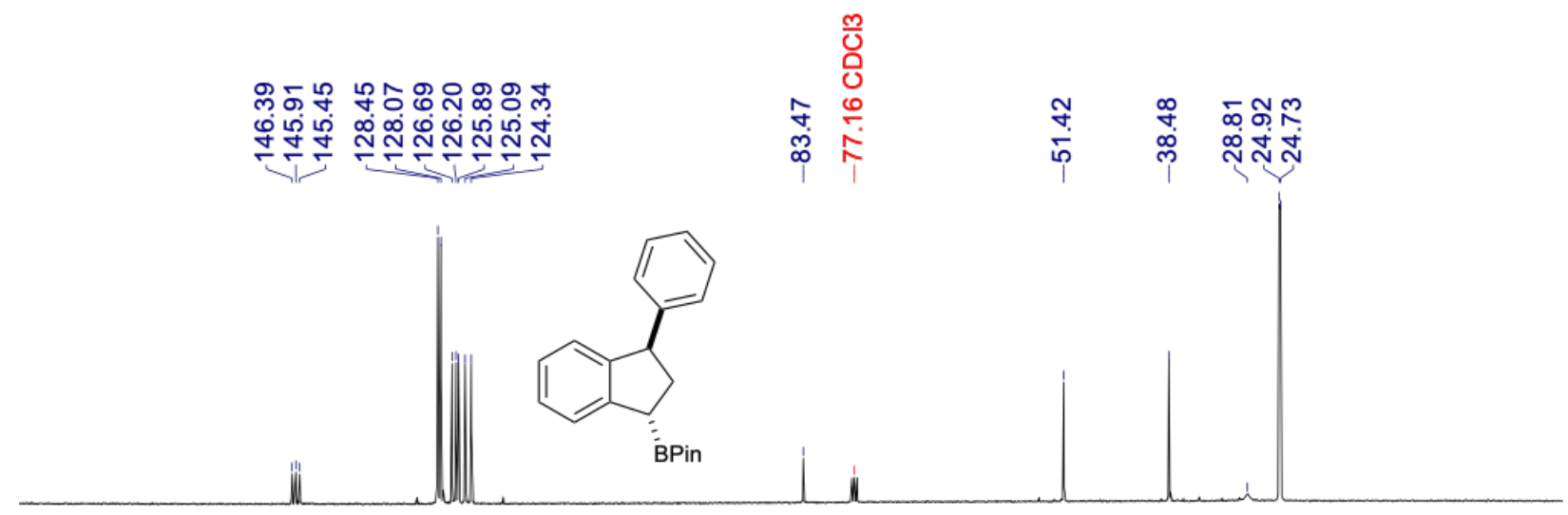

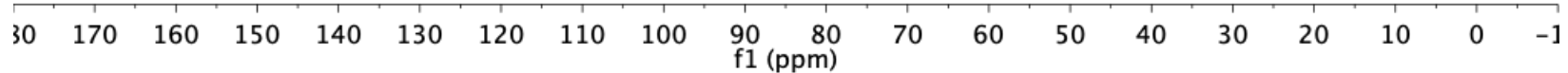

${ }^{13} \mathrm{C}$ NMR $\left(126 \mathrm{MHz}, \mathrm{CDCl}_{3}, 23{ }^{\circ} \mathrm{C}\right)$ spectrum of $2 e$.

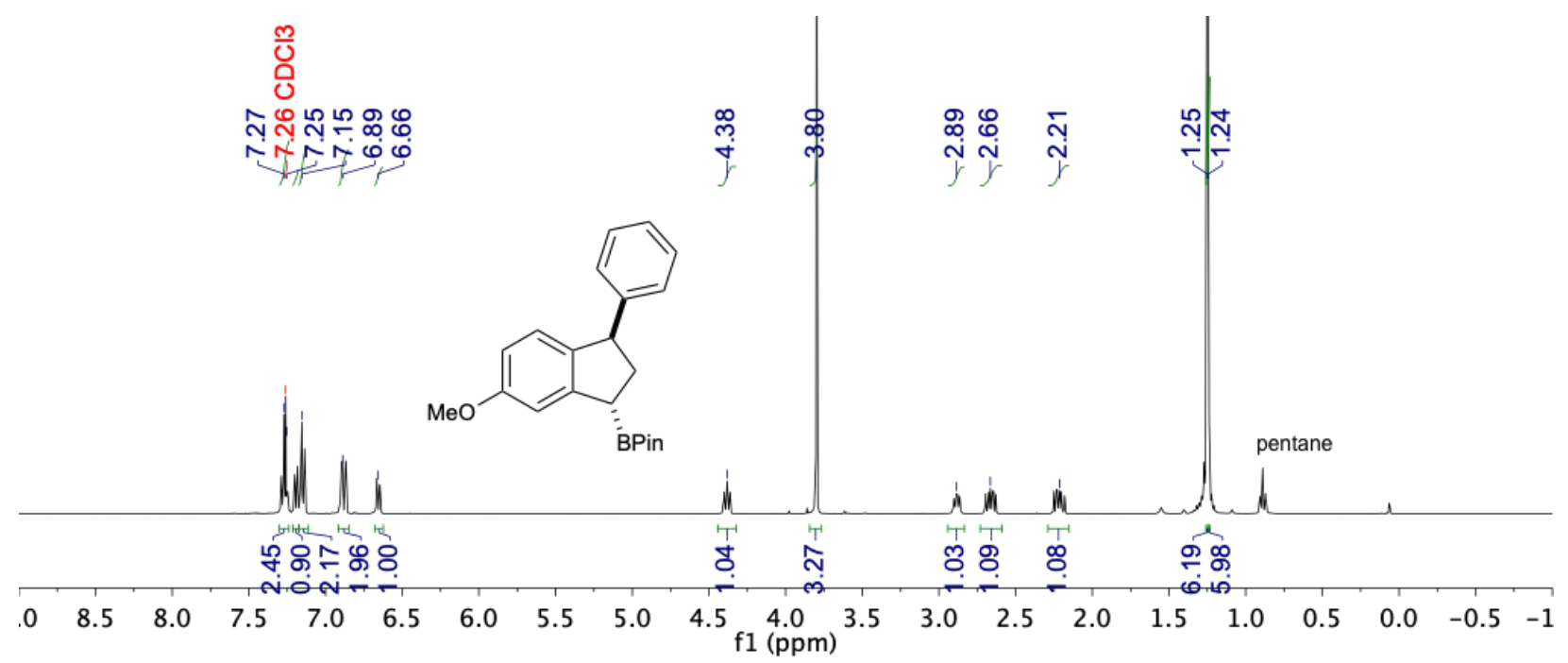

${ }^{1} \mathrm{H}$ NMR $\left(500 \mathrm{MHz}, \mathrm{CDCl}_{3}, 23^{\circ} \mathrm{C}\right)$ spectrum of $2 \mathrm{f}$. 


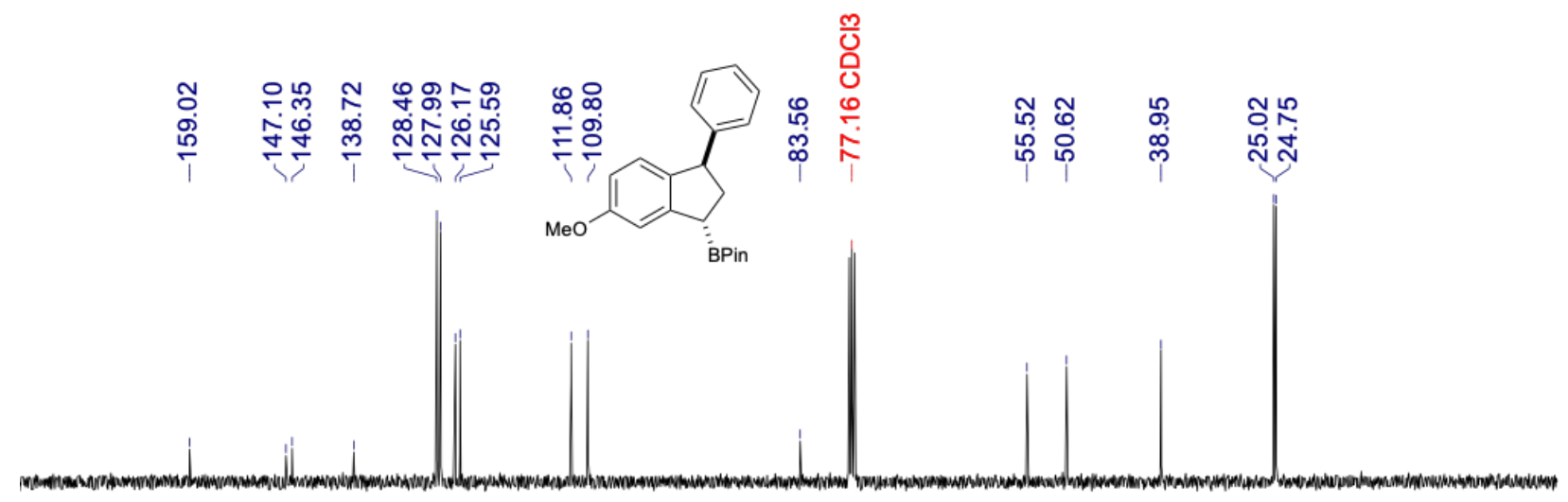

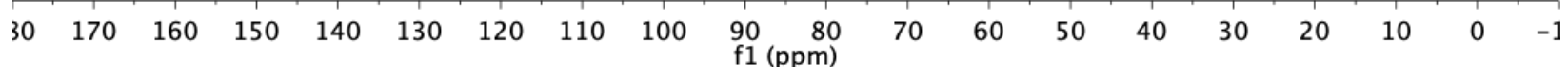

${ }^{13} \mathrm{C}$ NMR $\left(126 \mathrm{MHz}, \mathrm{CDCl}_{3}, 23^{\circ} \mathrm{C}\right)$ spectrum of $2 \mathrm{f}$.

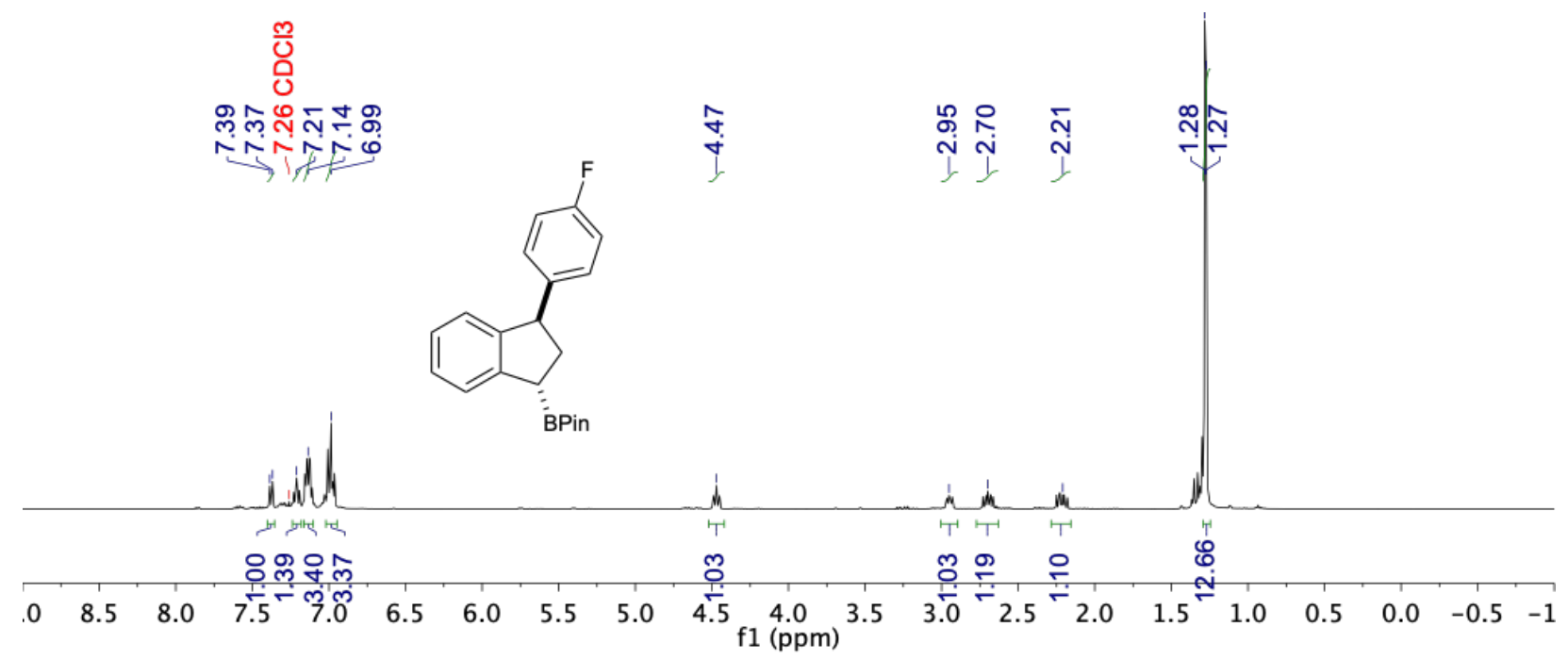

${ }^{1} \mathrm{H}$ NMR $\left(500 \mathrm{MHz}, \mathrm{CDCl}_{3}, 23^{\circ} \mathrm{C}\right)$ spectrum of $2 \mathrm{~g}$. 


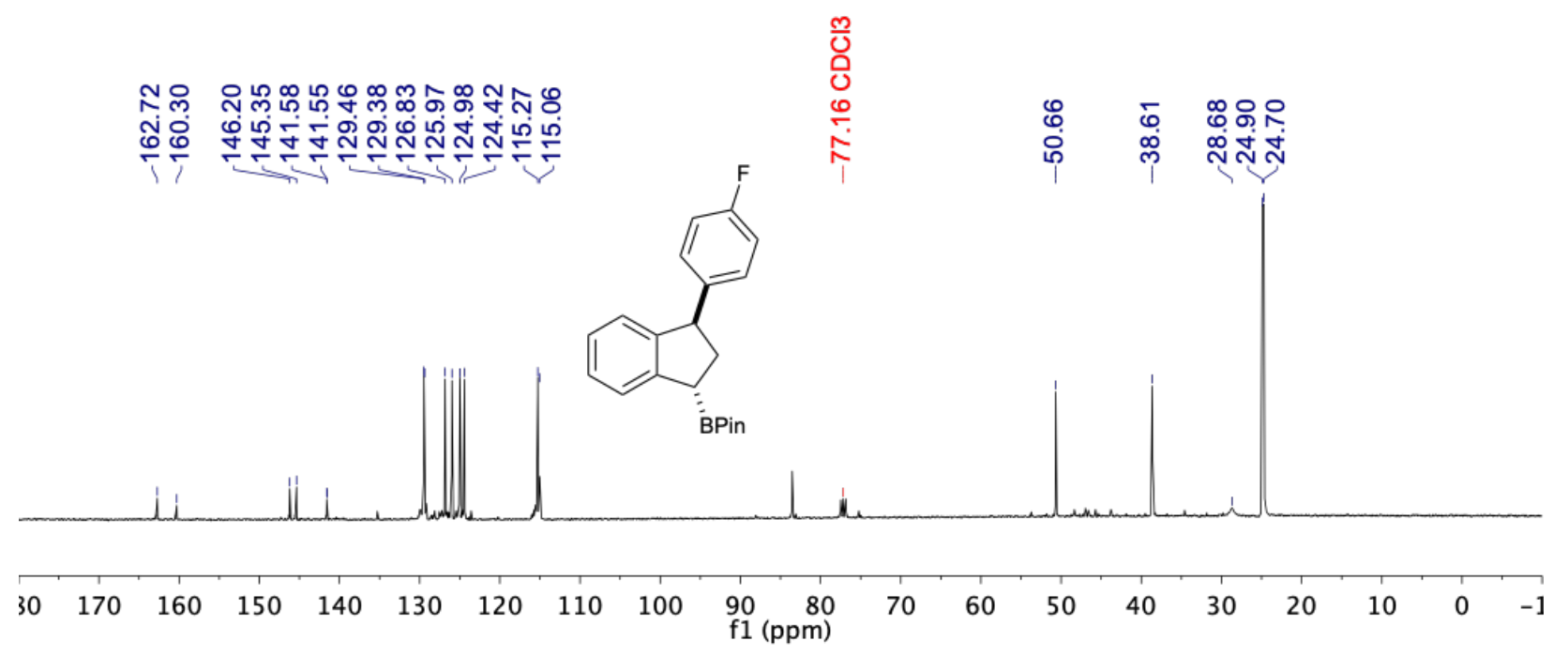

${ }^{13} \mathrm{C}$ NMR $\left(126 \mathrm{MHz}, \mathrm{CDCl}_{3}, 23^{\circ} \mathrm{C}\right)$ spectrum of $\mathbf{2 g}$.

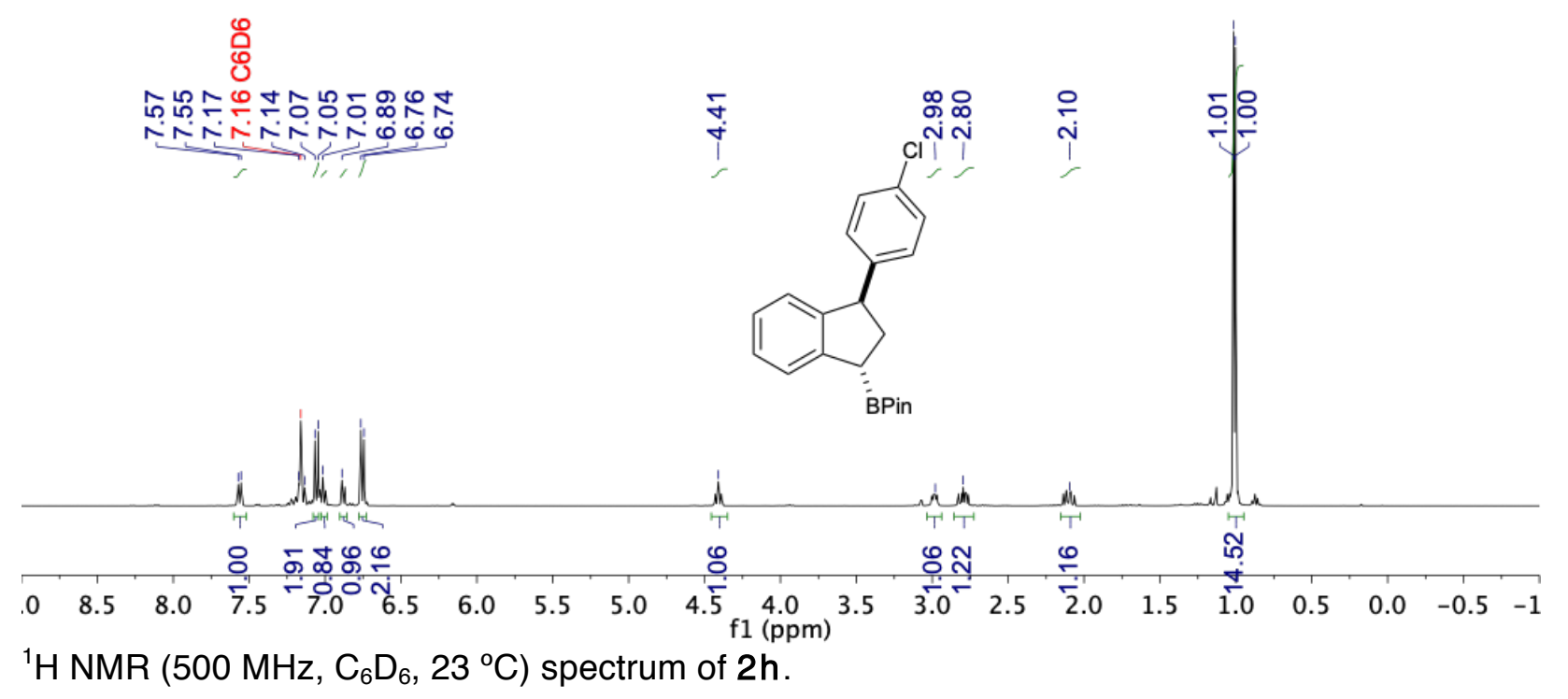




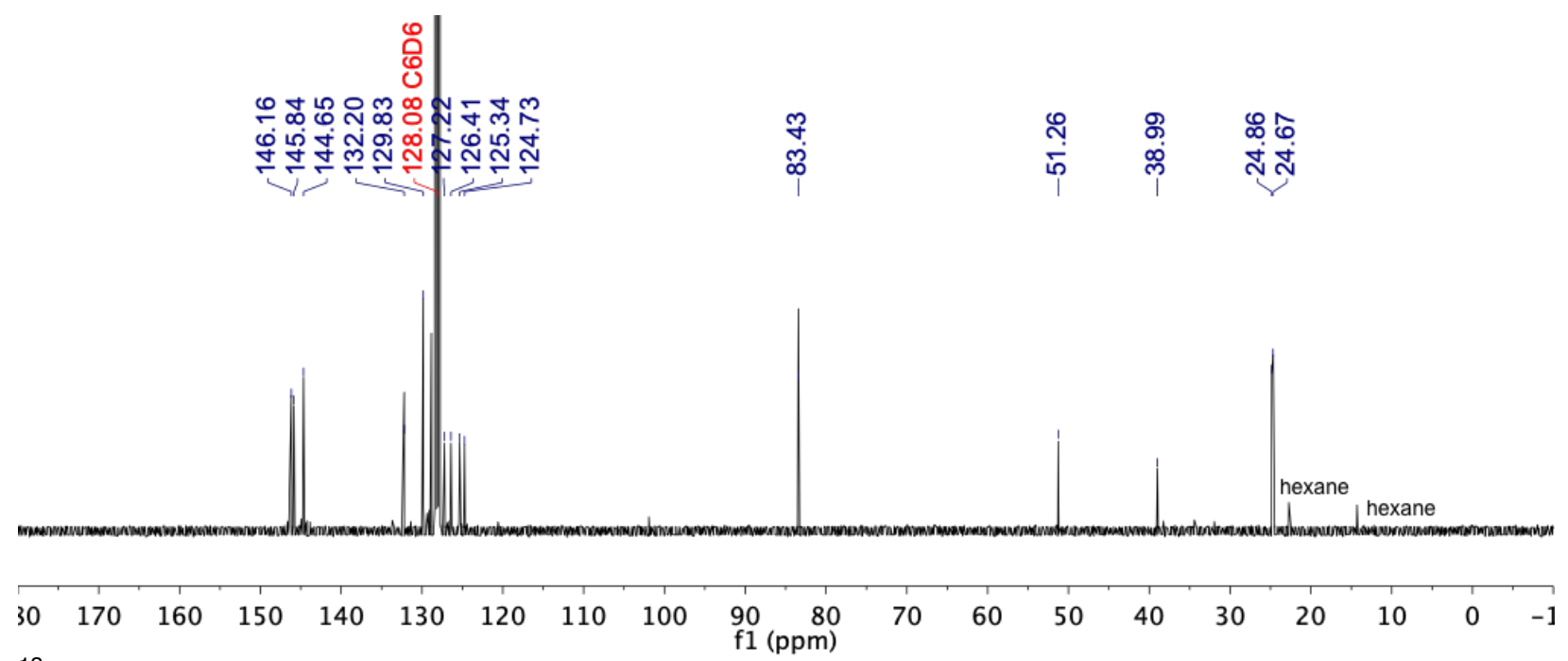

${ }^{13} \mathrm{C}$ NMR (126 MHz, $\left.\mathrm{C}_{6} \mathrm{D}_{6}, 23^{\circ} \mathrm{C}\right)$ spectrum of $2 \mathrm{~h}$.

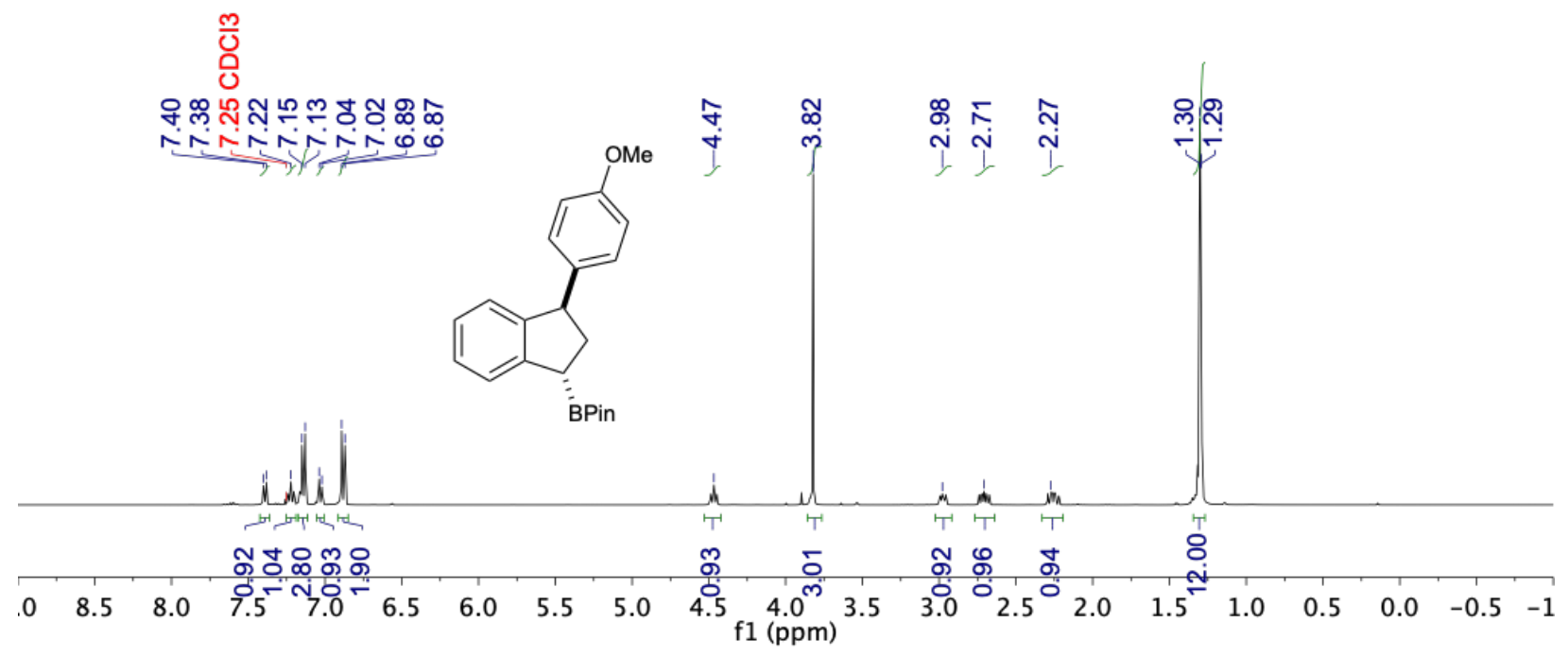

${ }^{1} \mathrm{H}$ NMR $\left(500 \mathrm{MHz}, \mathrm{CDCl}_{3}, 23^{\circ} \mathrm{C}\right)$ spectrum of $2 \mathbf{i}$. 

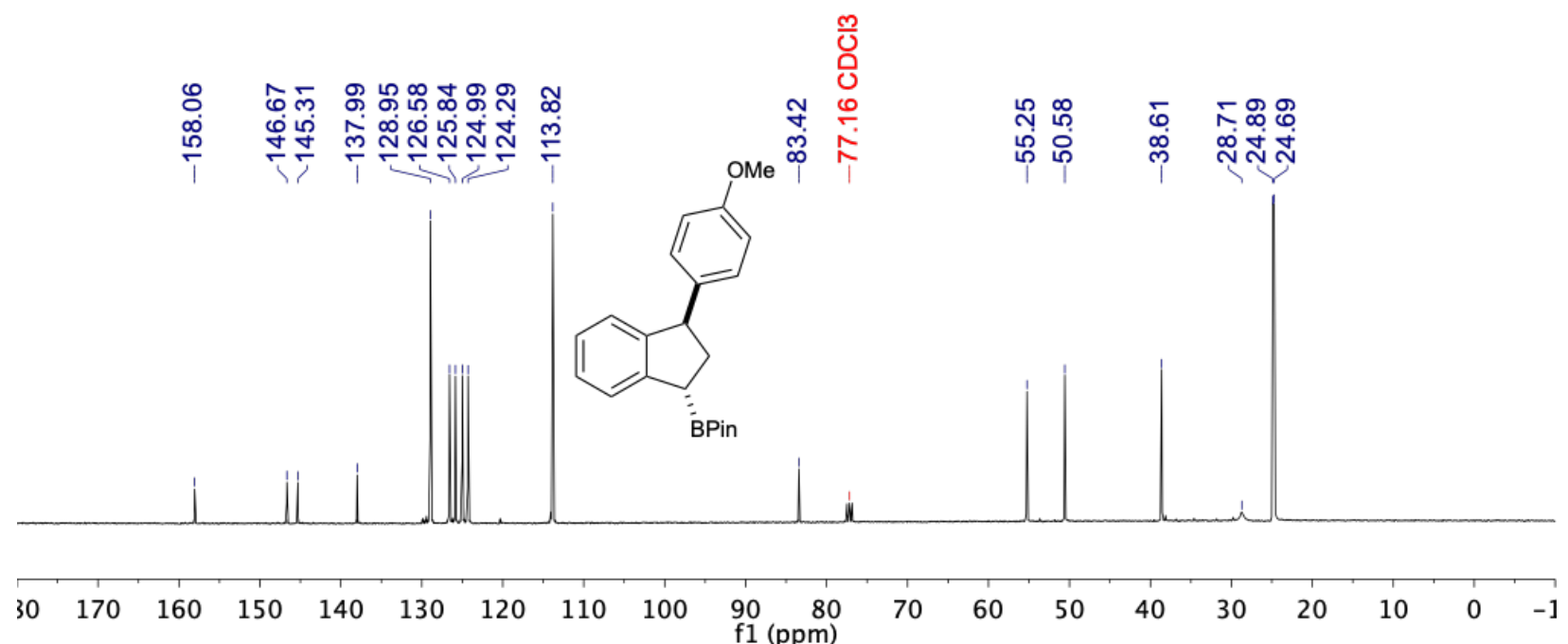

${ }^{13} \mathrm{C}$ NMR $\left(126 \mathrm{MHz}, \mathrm{CDCl}_{3}, 23^{\circ} \mathrm{C}\right)$ spectrum of $2 \mathbf{i}$.

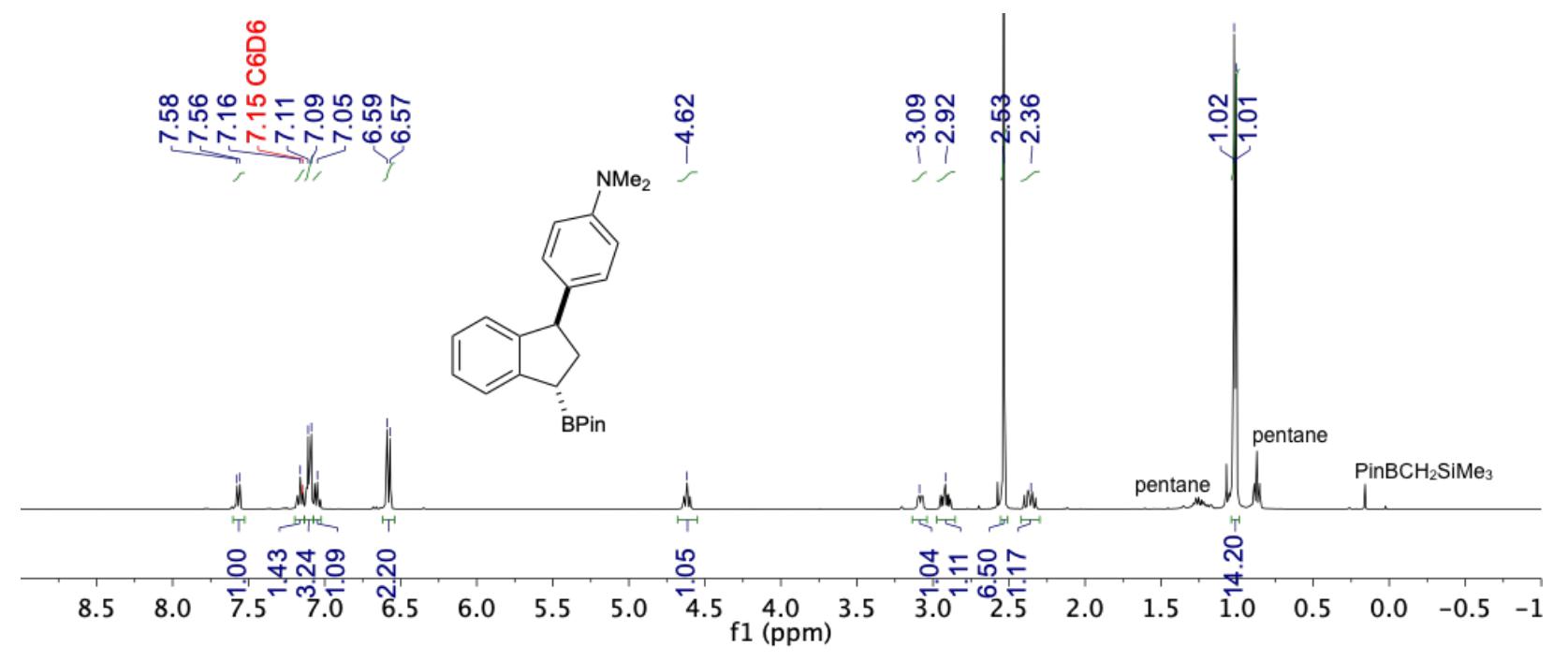

${ }^{1} \mathrm{H}$ NMR $\left(500 \mathrm{MHz}, \mathrm{C}_{6} \mathrm{D}_{6}, 23^{\circ} \mathrm{C}\right)$ spectrum of $\mathbf{2} \mathbf{j}$. 


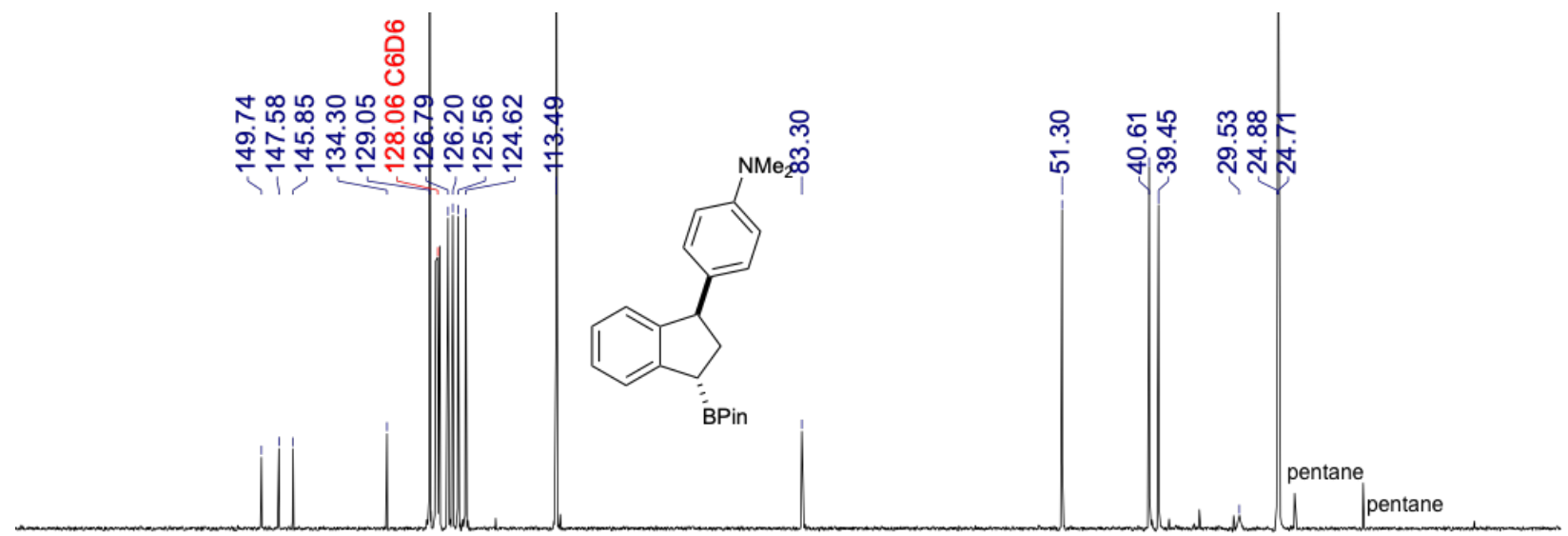

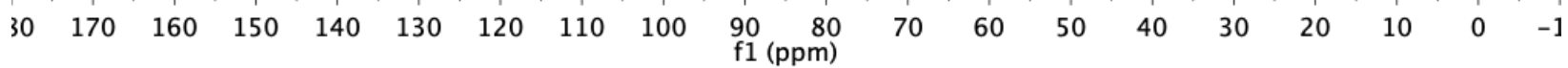

${ }^{13} \mathrm{C}$ NMR $\left(126 \mathrm{MHz}, \mathrm{C}_{6} \mathrm{D}_{6}, 23^{\circ} \mathrm{C}\right)$ spectrum of $2 \mathrm{j}$.

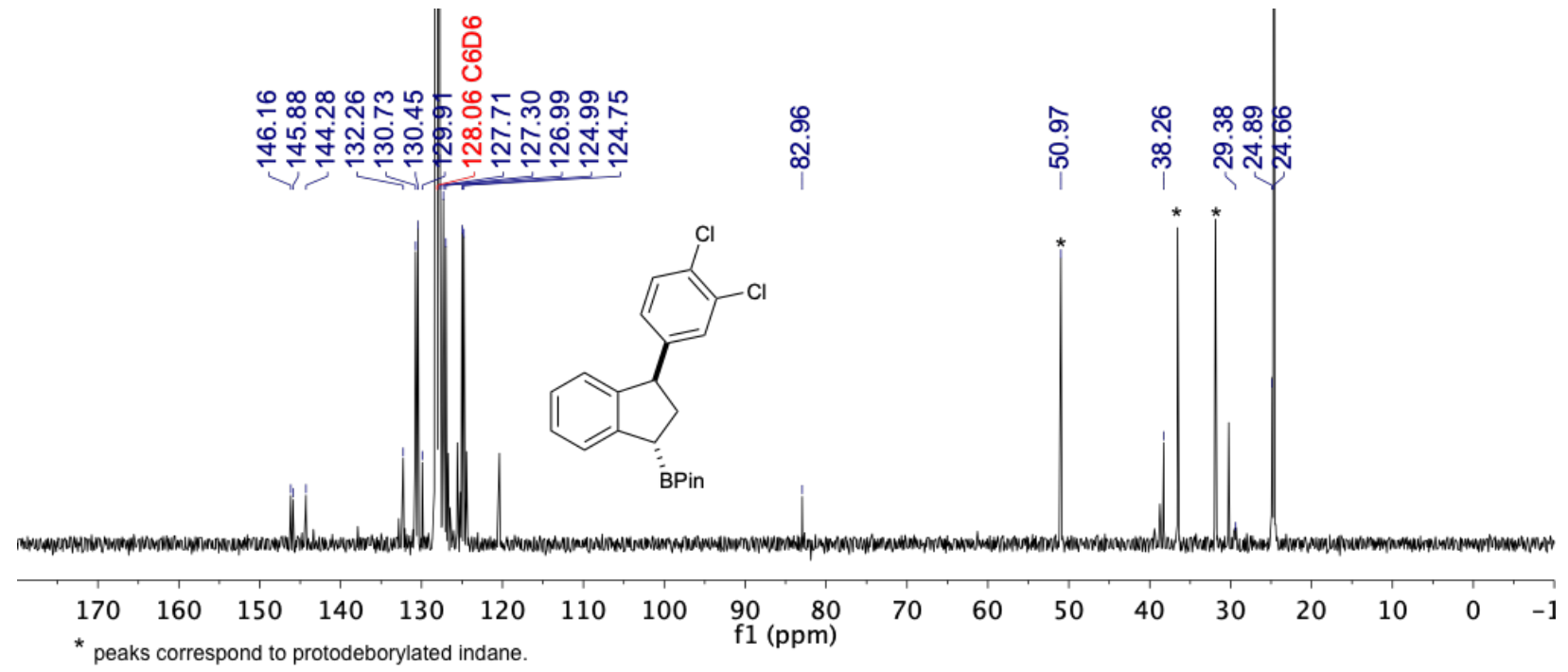

${ }^{13} \mathrm{C}$ NMR $\left(126 \mathrm{MHz}, \mathrm{C}_{6} \mathrm{D}_{6}, 23^{\circ} \mathrm{C}\right)$ spectrum of $2 \mathrm{k}$. 


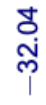

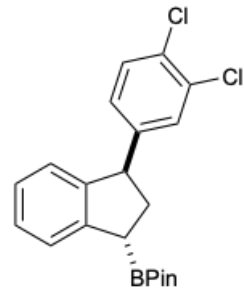

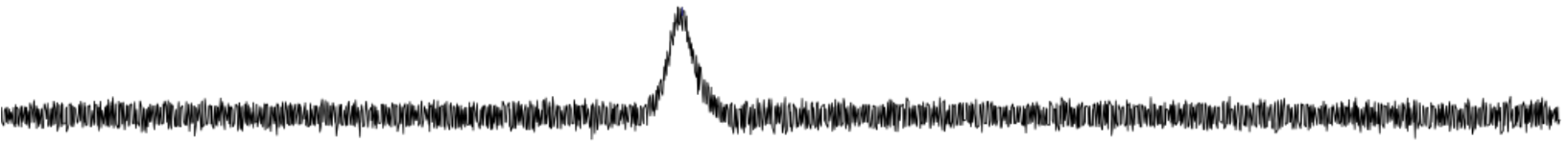

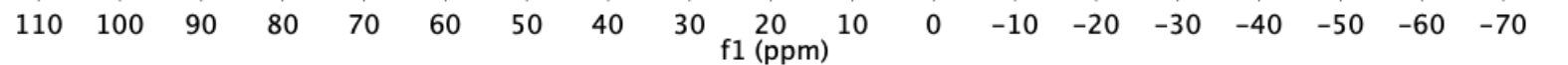

${ }^{11} \mathrm{~B}$ NMR $\left(96 \mathrm{MHz}, \mathrm{C}_{6} \mathrm{D}_{6}, 23^{\circ} \mathrm{C}\right)$ spectrum of $\mathbf{2 k}$.

m

risinjisin
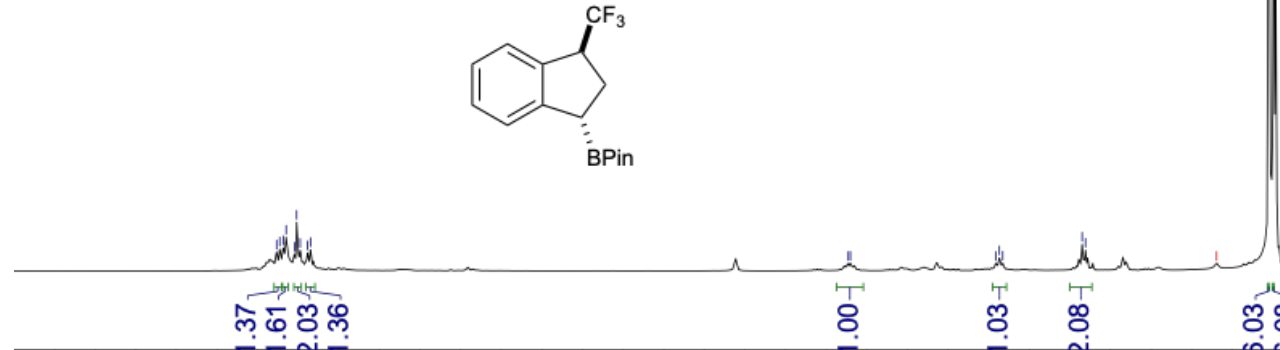

$\begin{array}{lllllllllllllllllll}8.5 & 8.0 & 7.5 & 7.0 & 6.5 & 6.0 & 5.5 & 5.0 & 4.5 \underset{\mathrm{f} 1 \underset{(\mathrm{ppm})}{4.0}}{4.5} & 3.0 & 2.5 & 2.0 & 1.5 & 1.0 & 0.5 & 0.0 & -0.5 & -1\end{array}$

${ }^{1} \mathrm{H}$ NMR $\left(400 \mathrm{MHz}, \mathrm{C}_{6} \mathrm{D}_{6}, 23^{\circ} \mathrm{C}\right)$ spectrum of $2 \mathrm{I}$. 


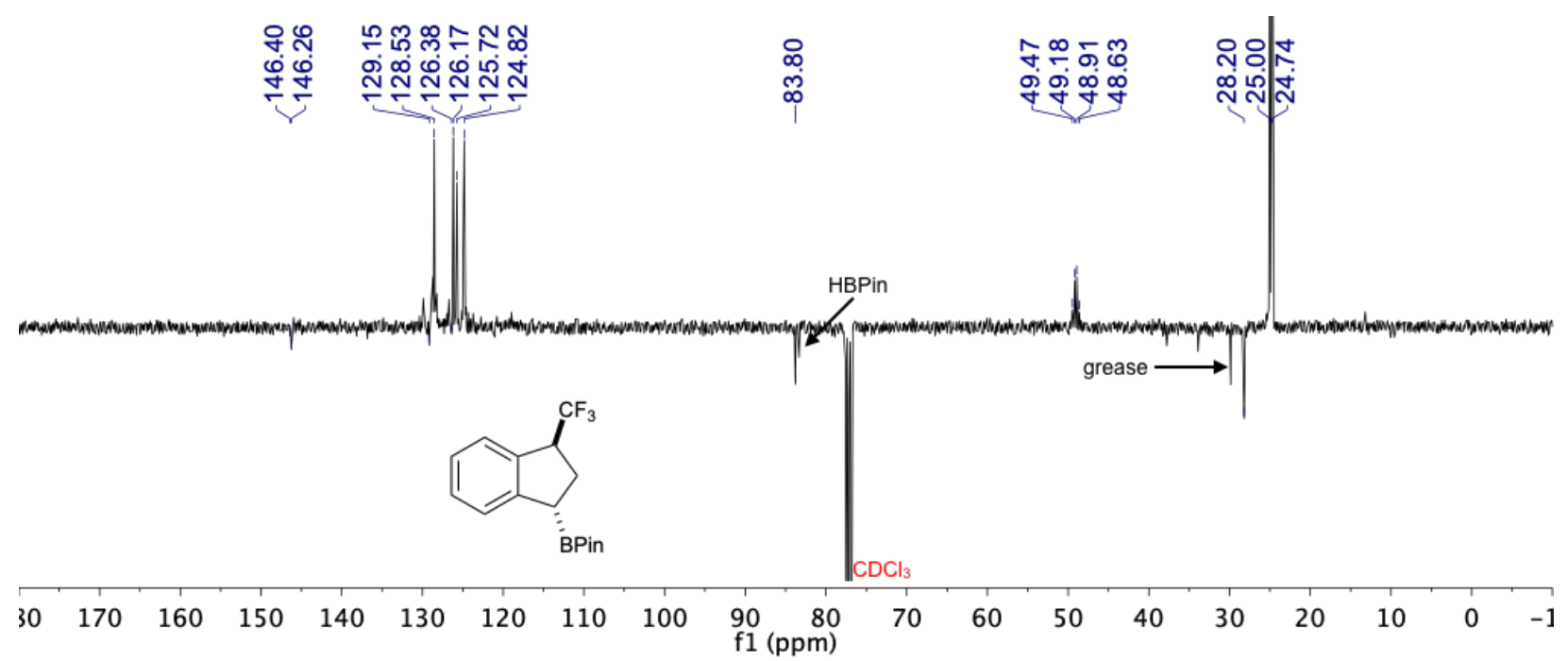

${ }^{13} \mathrm{C}$ NMR $\left(101 \mathrm{MHz}, \mathrm{CDCl}_{3}, 23^{\circ} \mathrm{C}\right)$ spectrum of $2 \mathrm{l}$.

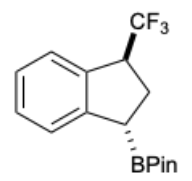

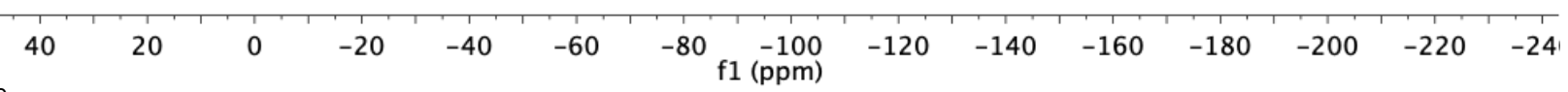

${ }^{19} \mathrm{~F} \mathrm{NMR}\left(367 \mathrm{MHz}, \mathrm{CDCl}_{3}, 23^{\circ} \mathrm{C}\right)$ spectrum of $2 \mathrm{l}$. 


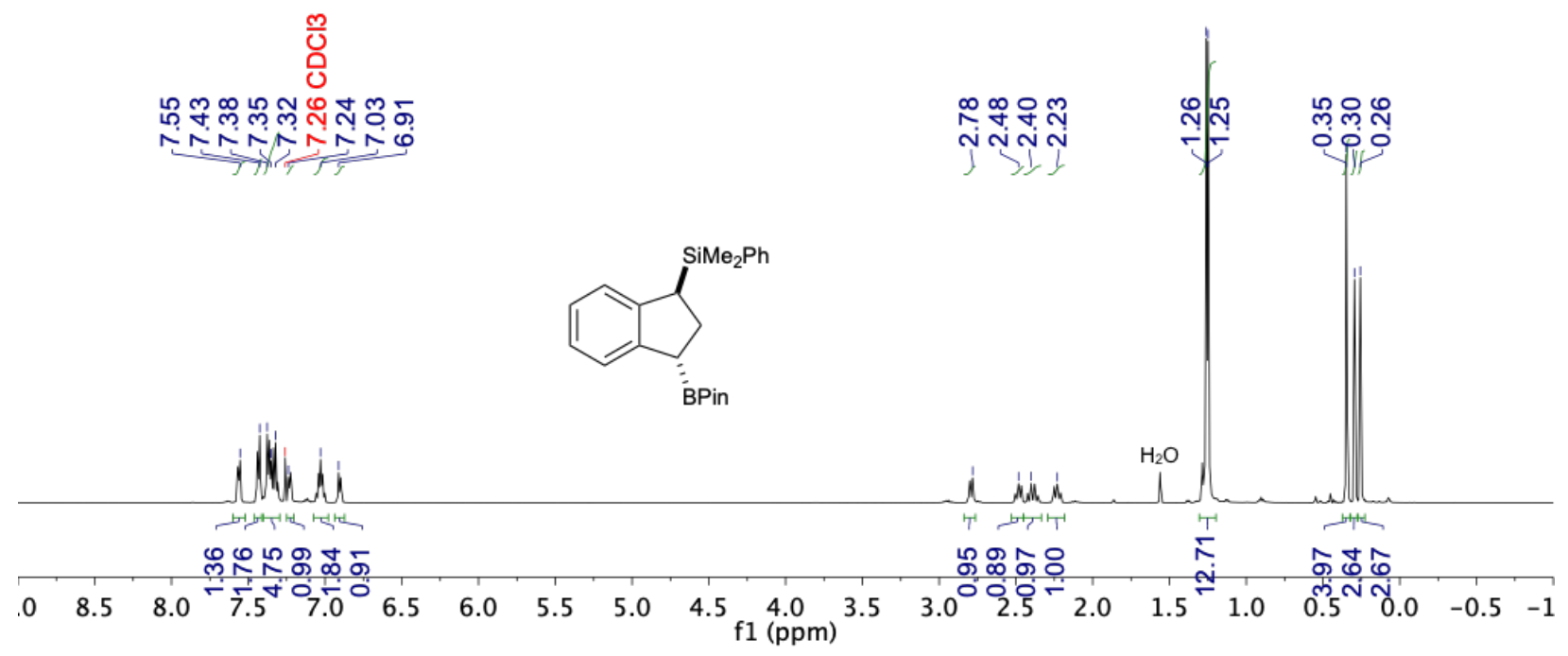

${ }^{1} \mathrm{H}$ NMR $\left(500 \mathrm{MHz}, \mathrm{CDCl}_{3}, 23^{\circ} \mathrm{C}\right)$ spectrum of $2 \mathrm{~m}$.

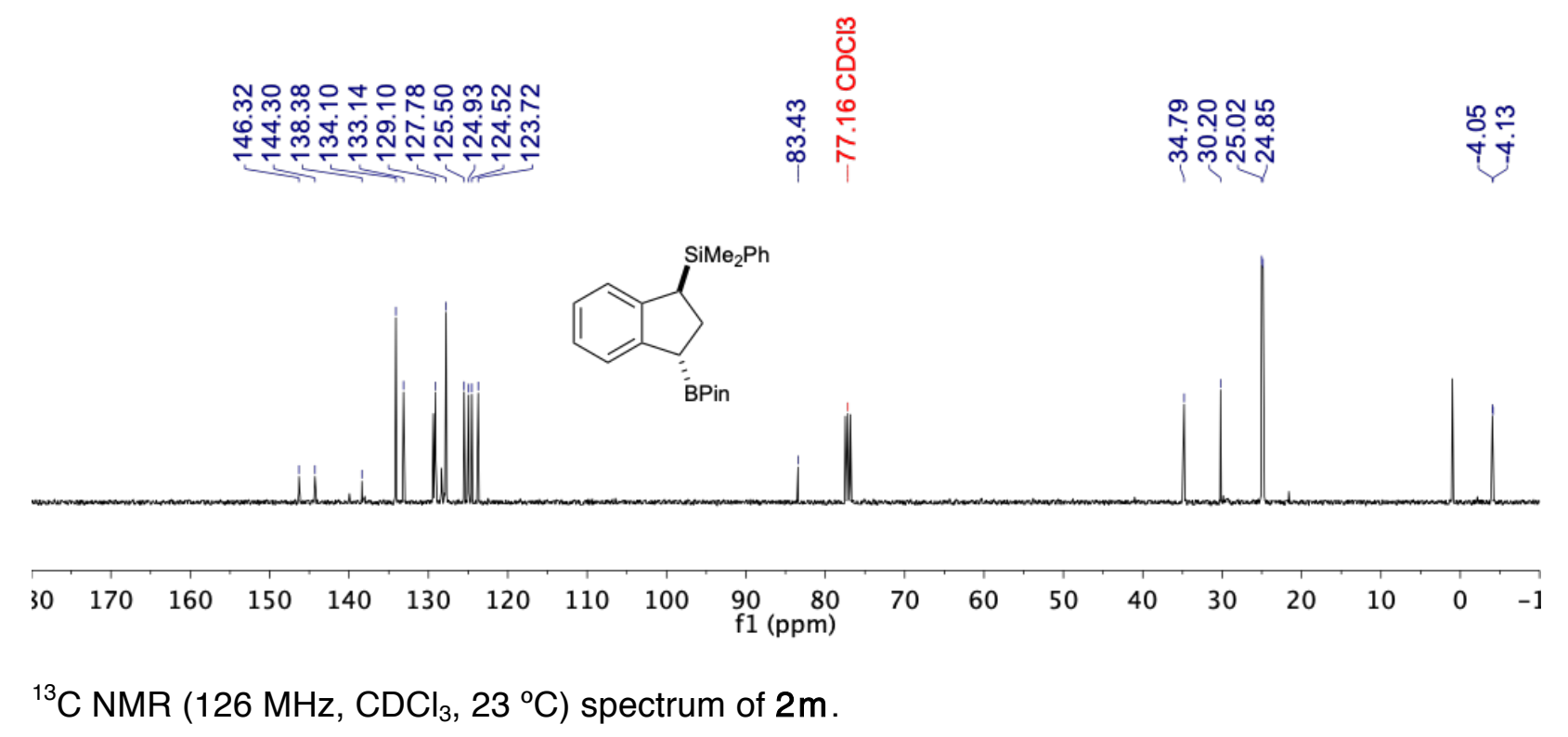




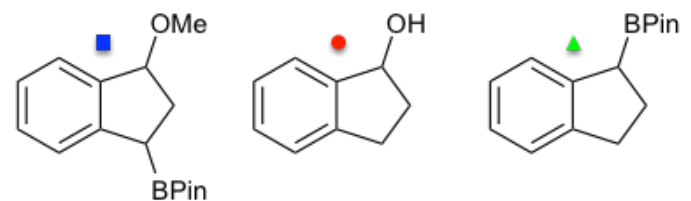

1:1 cis:trans

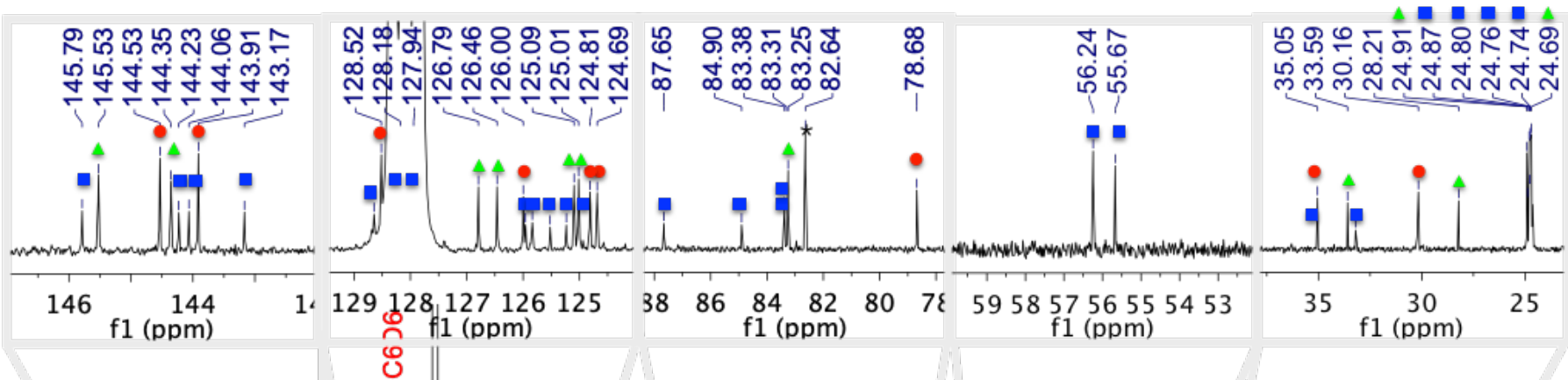

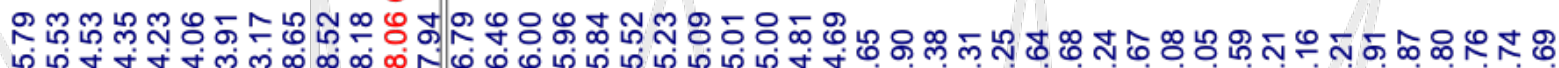

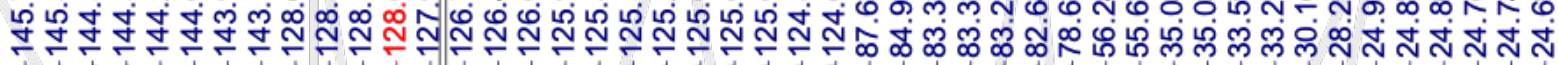

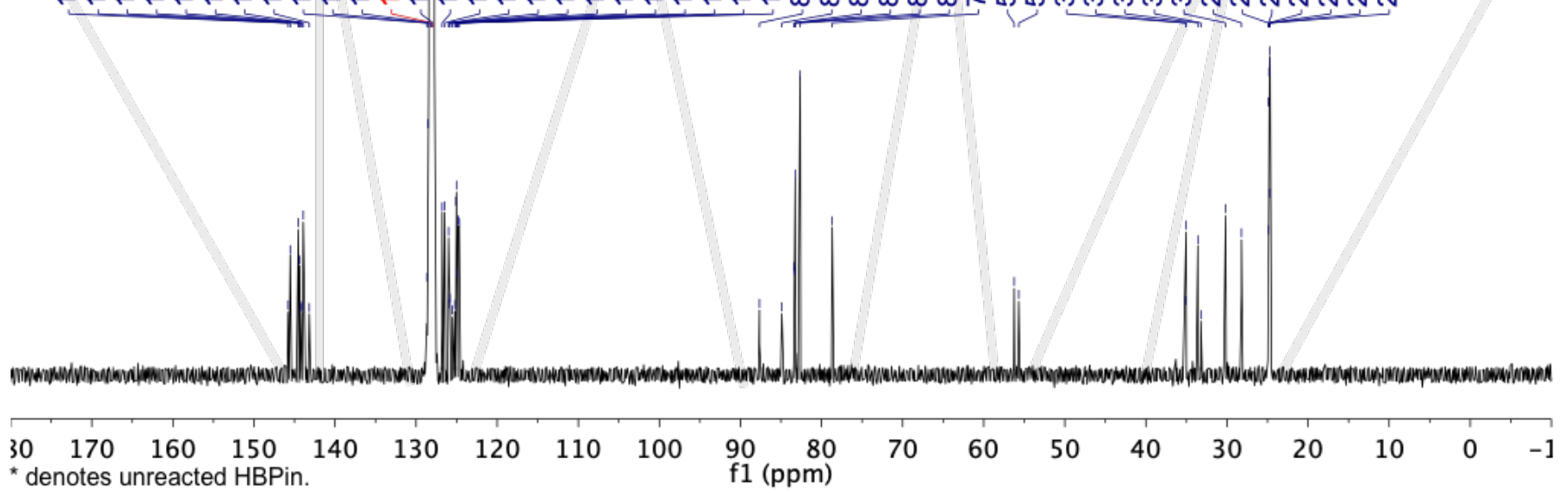

${ }^{13} \mathrm{C}$ NMR $\left(126 \mathrm{MHz}, \mathrm{C}_{6} \mathrm{D}_{6}, 23^{\circ} \mathrm{C}\right)$ spectrum of $2 \mathrm{n}$ showing product isolated as a $1: 1$ mixture of cis and trans isomers, along with 1-indanol and 1-BPin-indane side products. Insets are zoomed in sections of the spectrum. Assignments for 1-indanol and 1-BPin-indane are in agreement with previously reported values. 


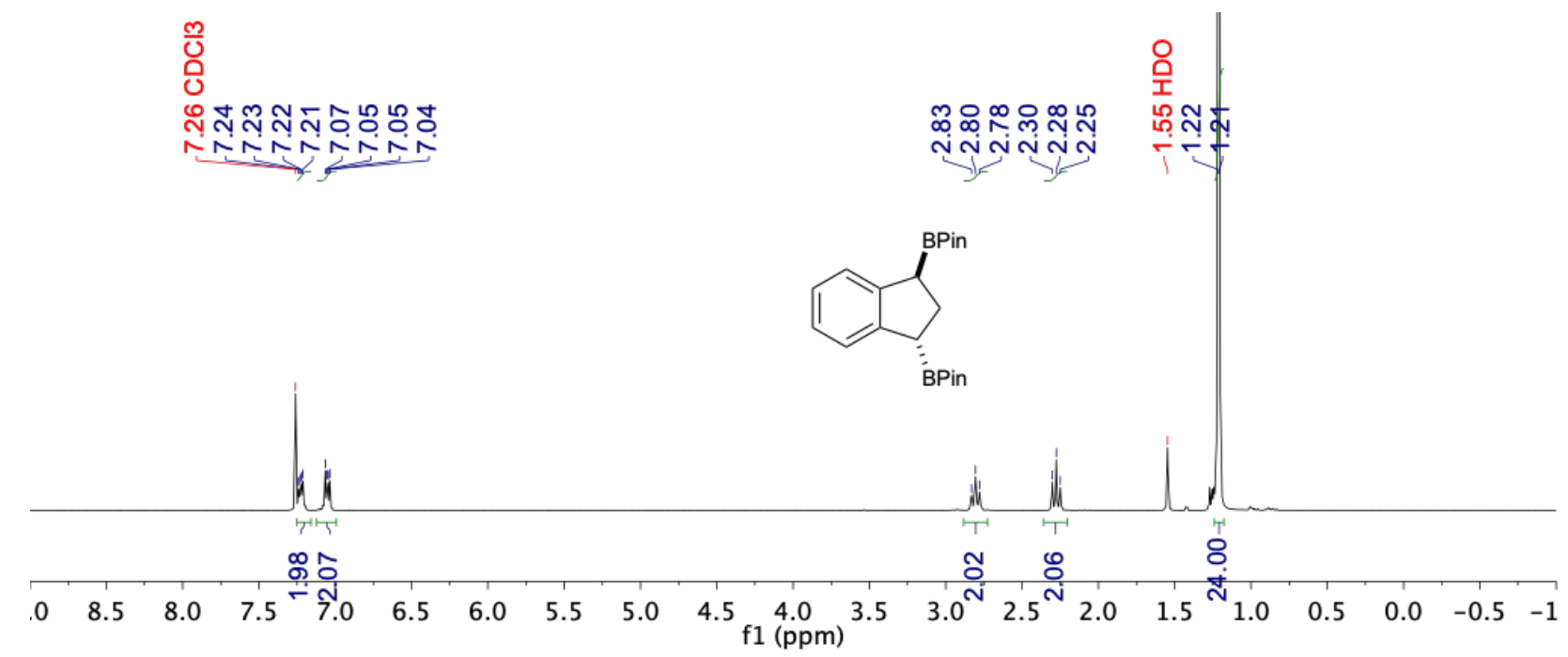

${ }^{1} \mathrm{H}$ NMR $\left(500 \mathrm{MHz}, \mathrm{CDCl}_{3}, 23^{\circ} \mathrm{C}\right)$ spectrum of 20.

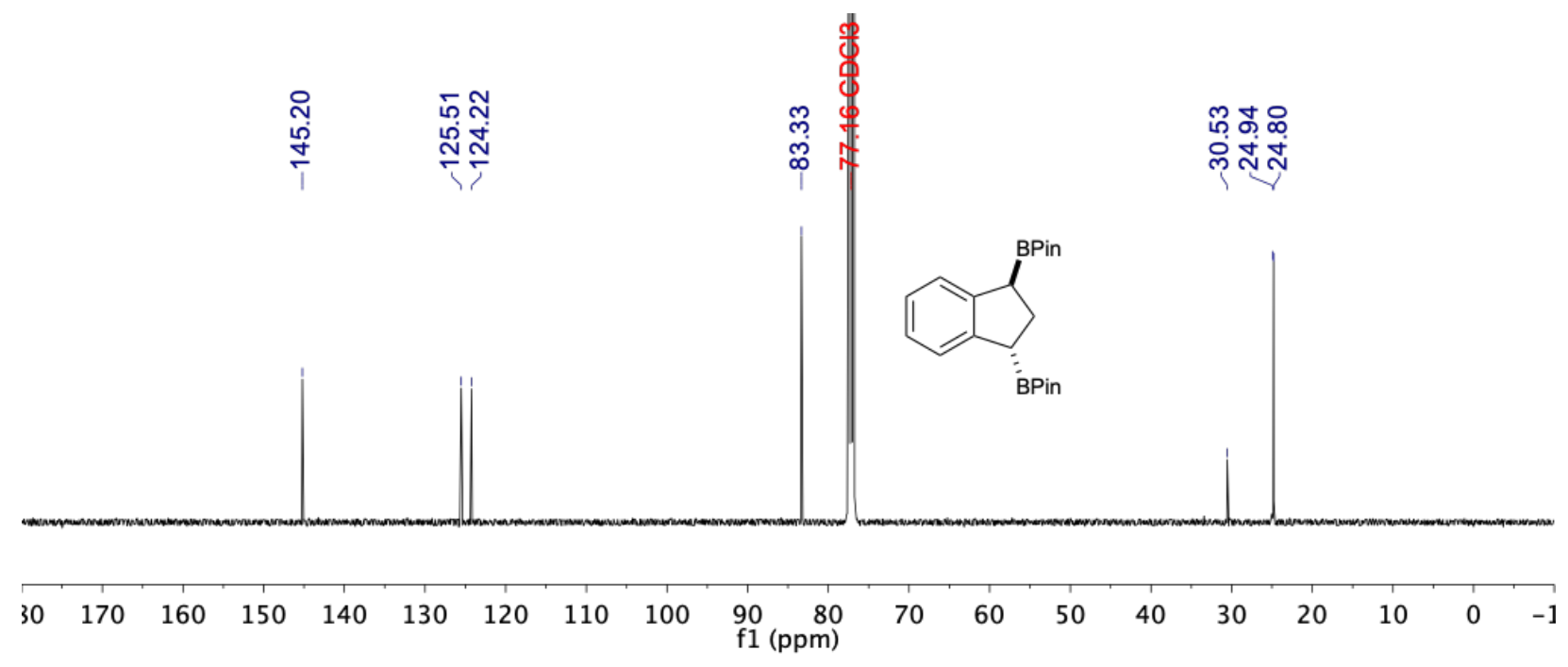

${ }^{13} \mathrm{C}$ NMR $\left(126 \mathrm{MHz}, \mathrm{CDCl}_{3}, 23^{\circ} \mathrm{C}\right)$ spectrum of 20. 


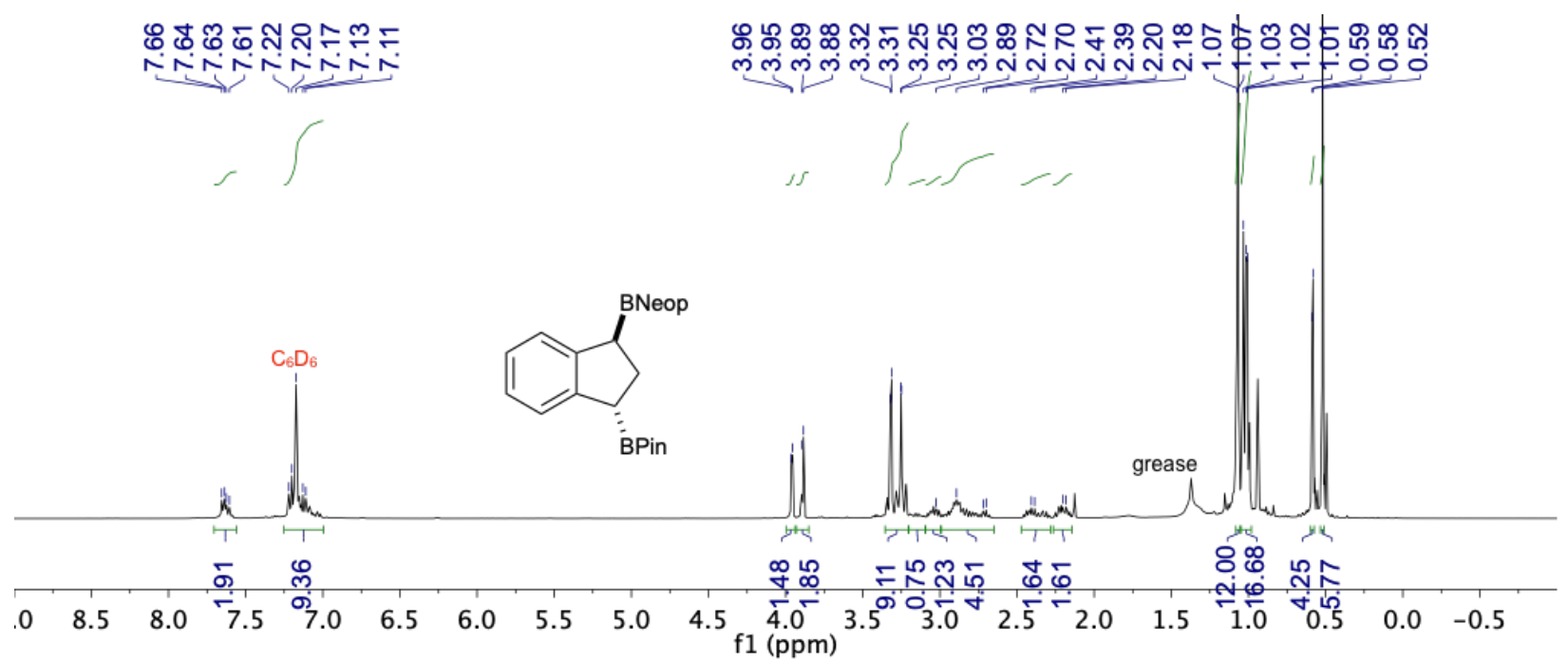

${ }^{1} \mathrm{H}$ NMR $\left(500 \mathrm{MHz}, \mathrm{C}_{6} \mathrm{D}_{6}, 23^{\circ} \mathrm{C}\right)$ spectrum of $2 \mathrm{p}$. 


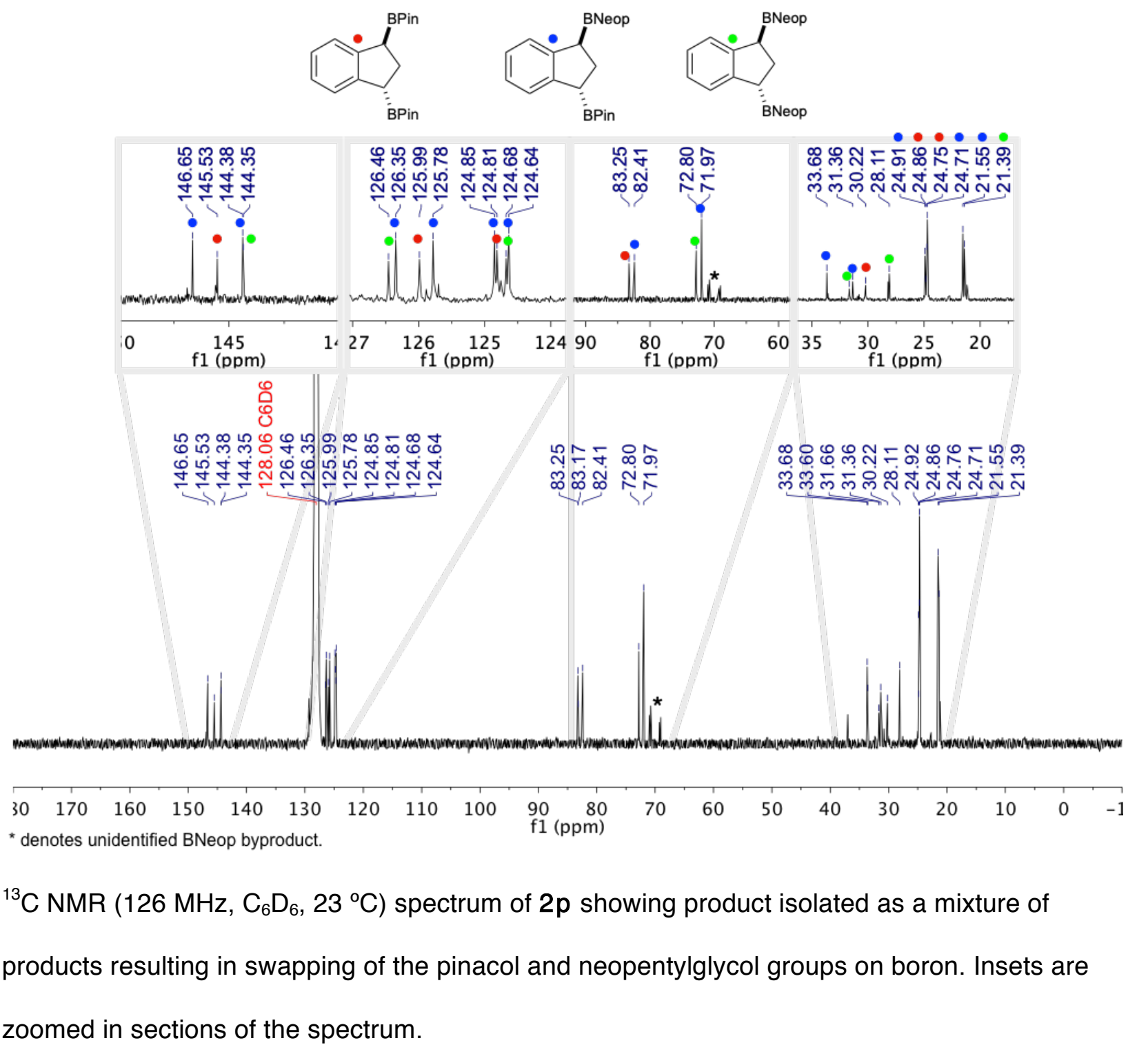




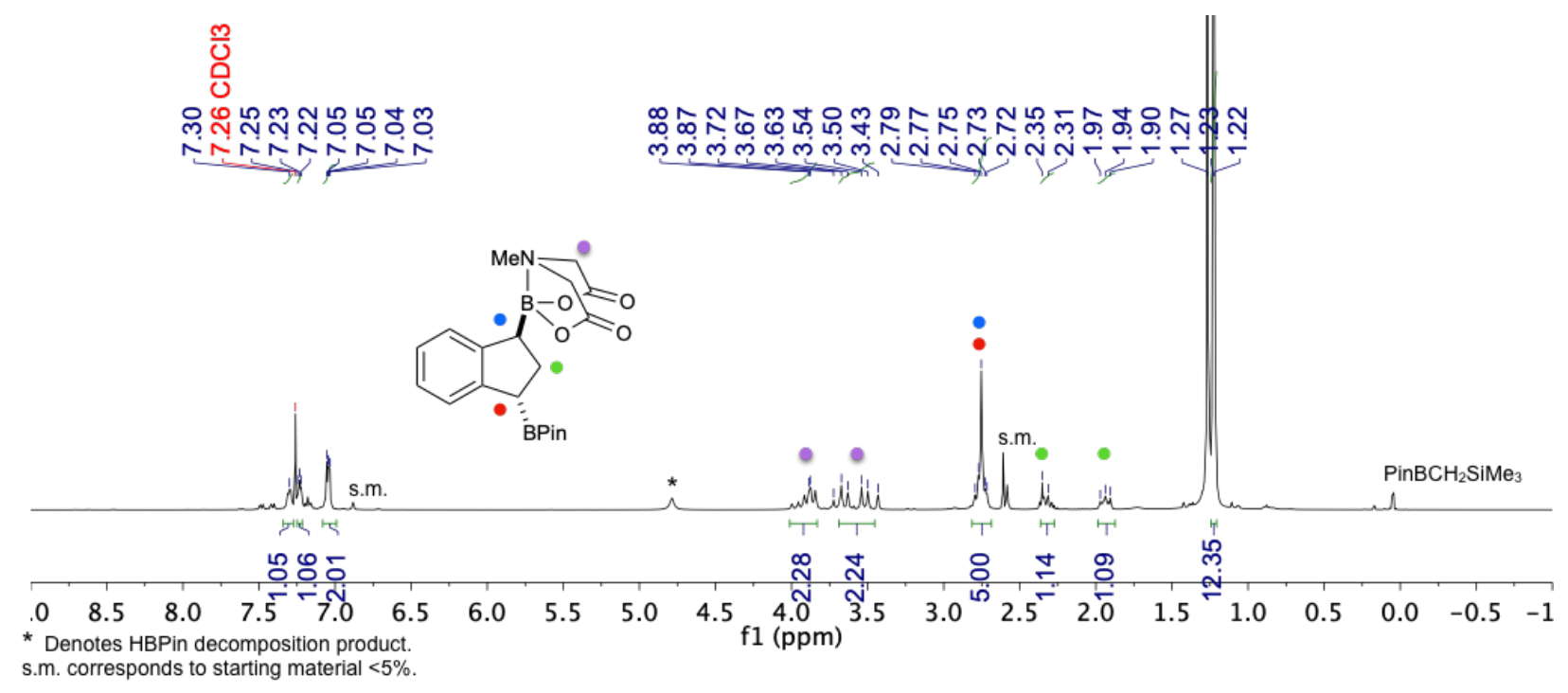

${ }^{1} \mathrm{H}$ NMR $\left(500 \mathrm{MHz}, \mathrm{CDCl}_{3}, 23^{\circ} \mathrm{C}\right)$ spectrum of $2 \mathrm{p}$.

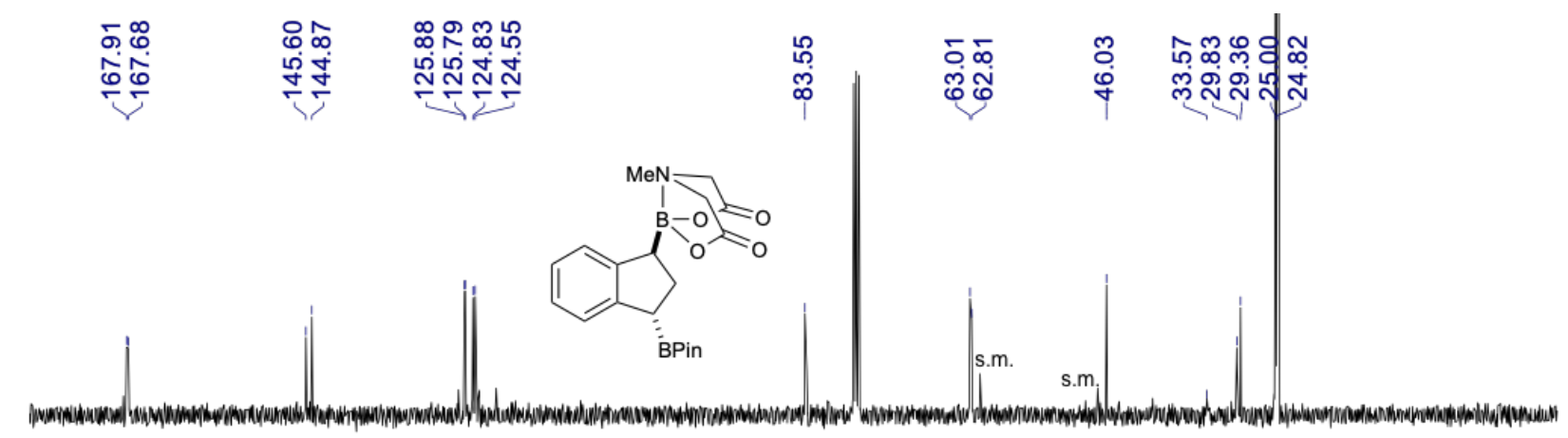

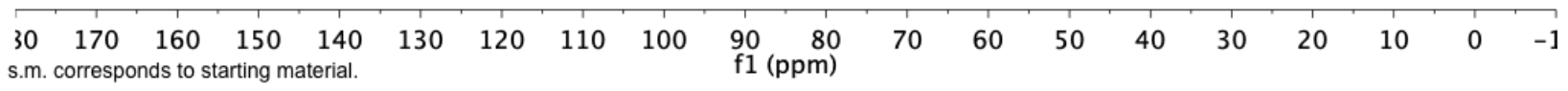

${ }^{13} \mathrm{C}$ NMR $\left(126 \mathrm{MHz}, \mathrm{CDCl}_{3}, 23{ }^{\circ} \mathrm{C}\right)$ spectrum of $2 \mathrm{p}$. 


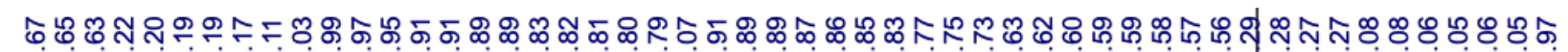

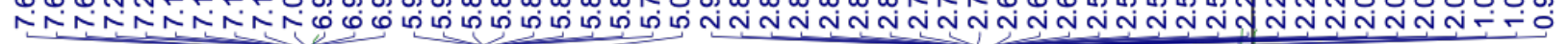

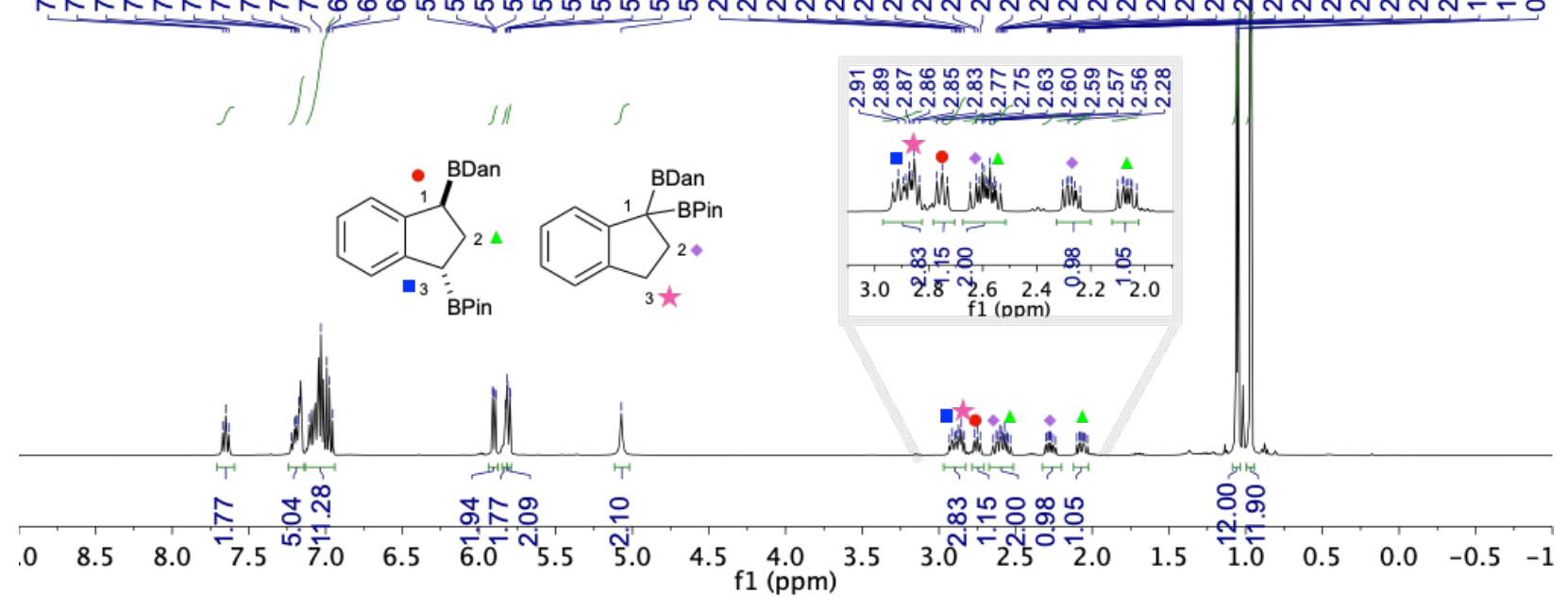

${ }^{1} \mathrm{H}$ NMR $\left(500 \mathrm{MHz}, \mathrm{C}_{6} \mathrm{D}_{6}, 23^{\circ} \mathrm{C}\right)$ spectrum of $2 \mathrm{r}$.

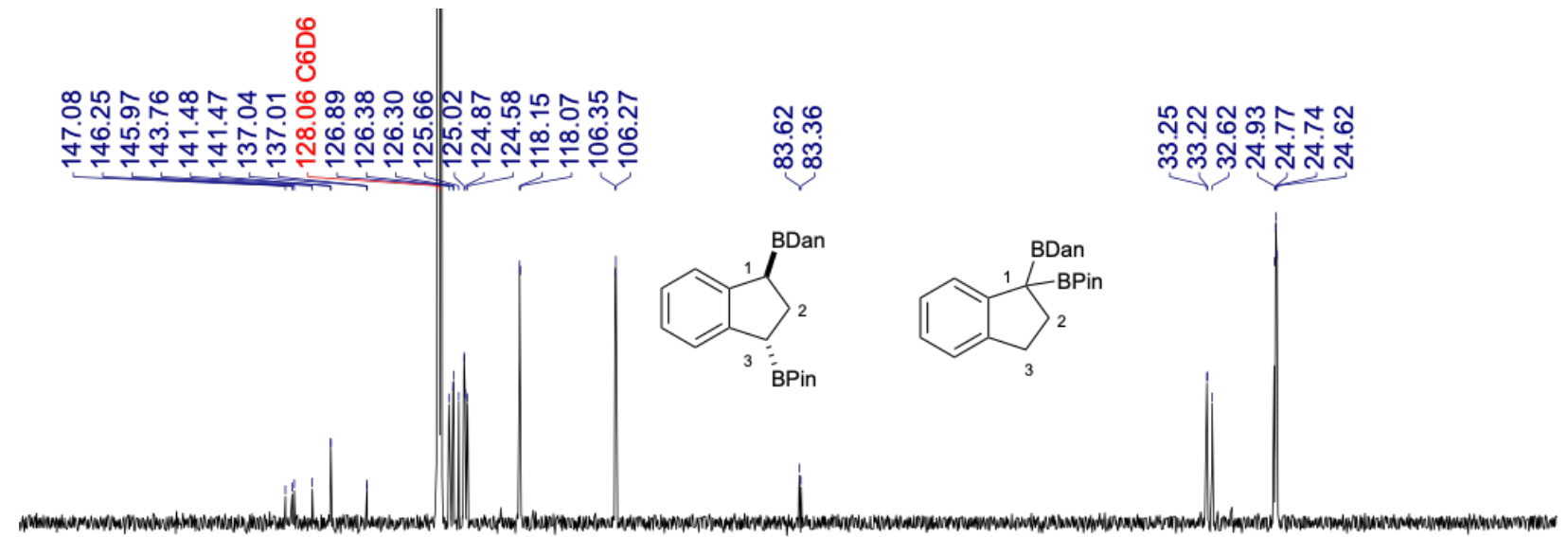

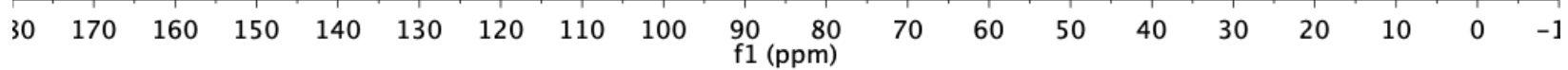

${ }^{13} \mathrm{C}$ NMR $\left(126 \mathrm{MHz}, \mathrm{C}_{6} \mathrm{D}_{6}, 23^{\circ} \mathrm{C}\right)$ spectrum of $2 \mathrm{r}$. 


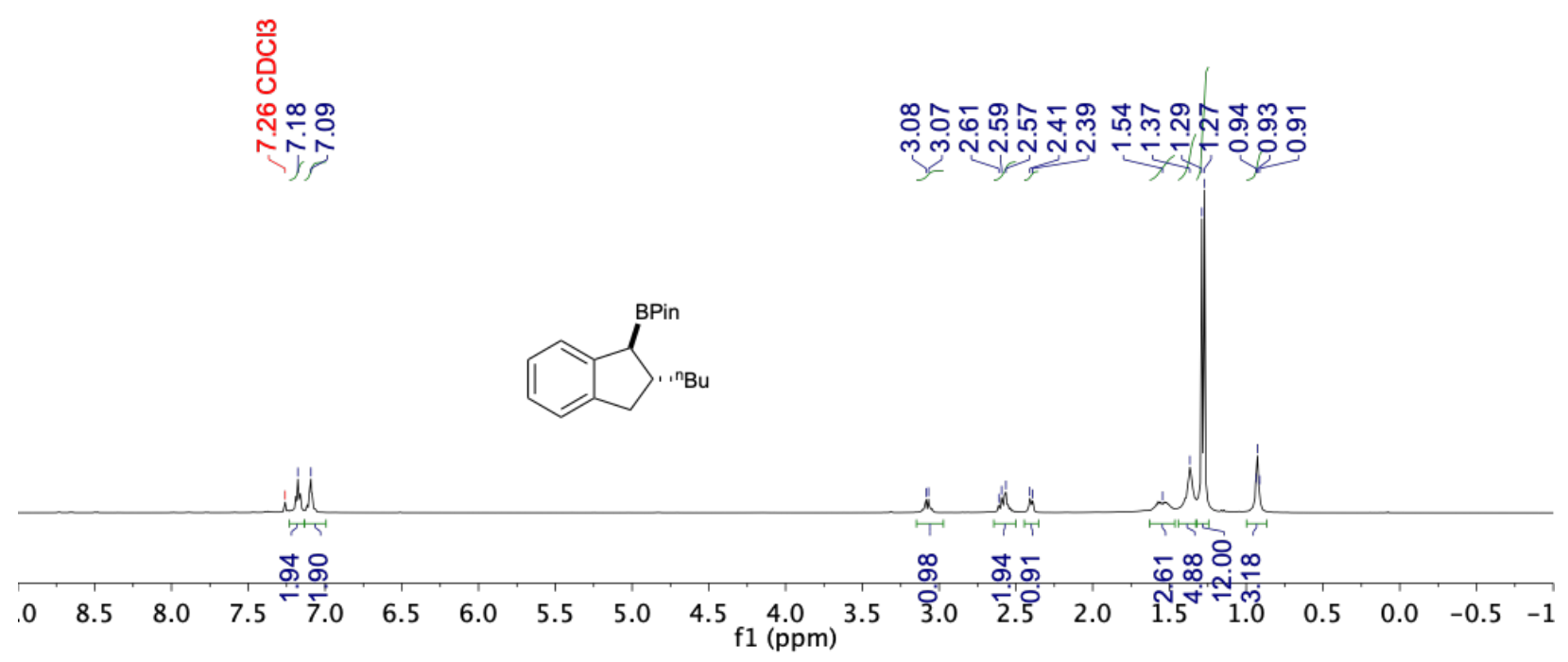

${ }^{1} \mathrm{H}$ NMR (400 MHz, $\left.\mathrm{CDCl}_{3}, 23^{\circ} \mathrm{C}\right)$ spectrum of $2 \mathrm{~s}$.

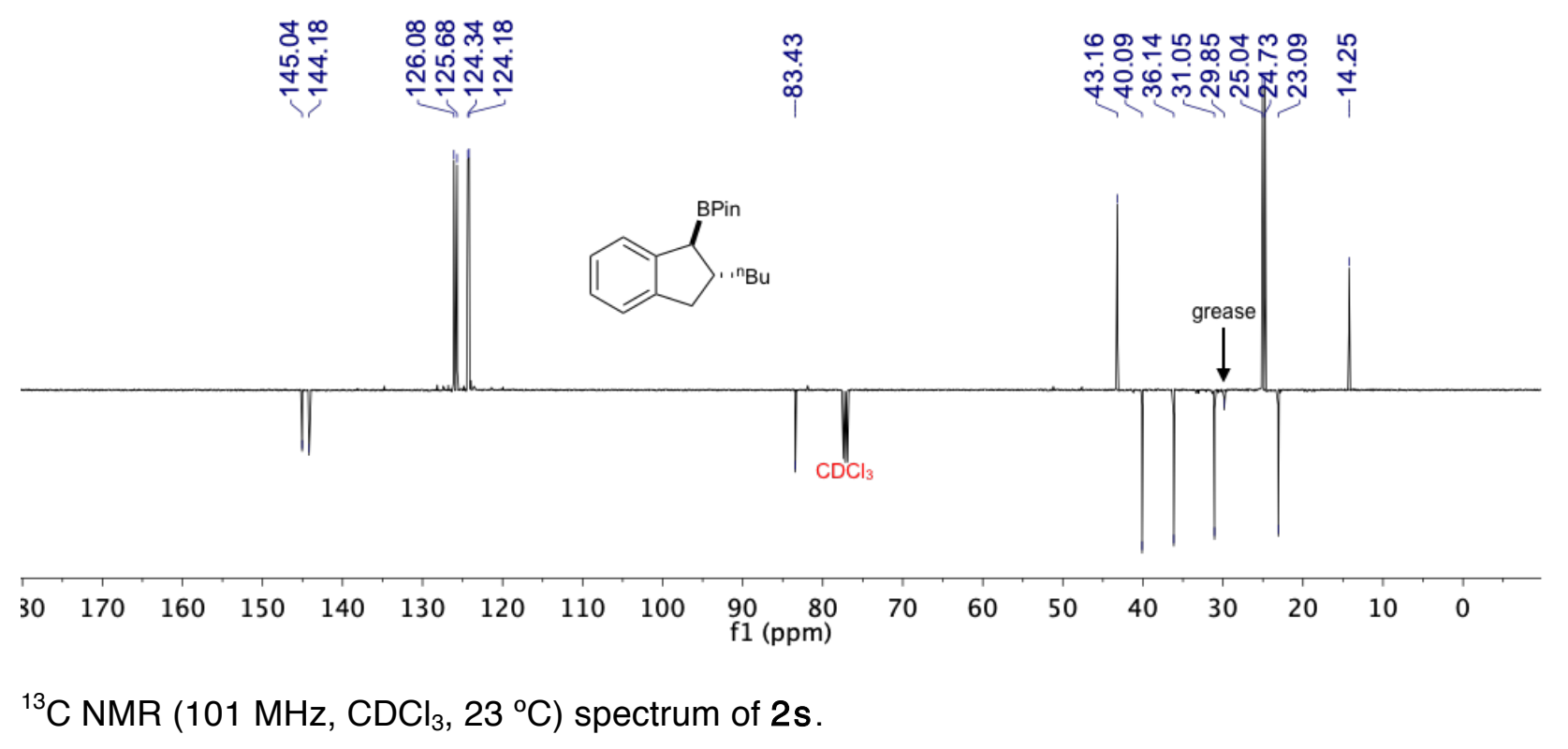




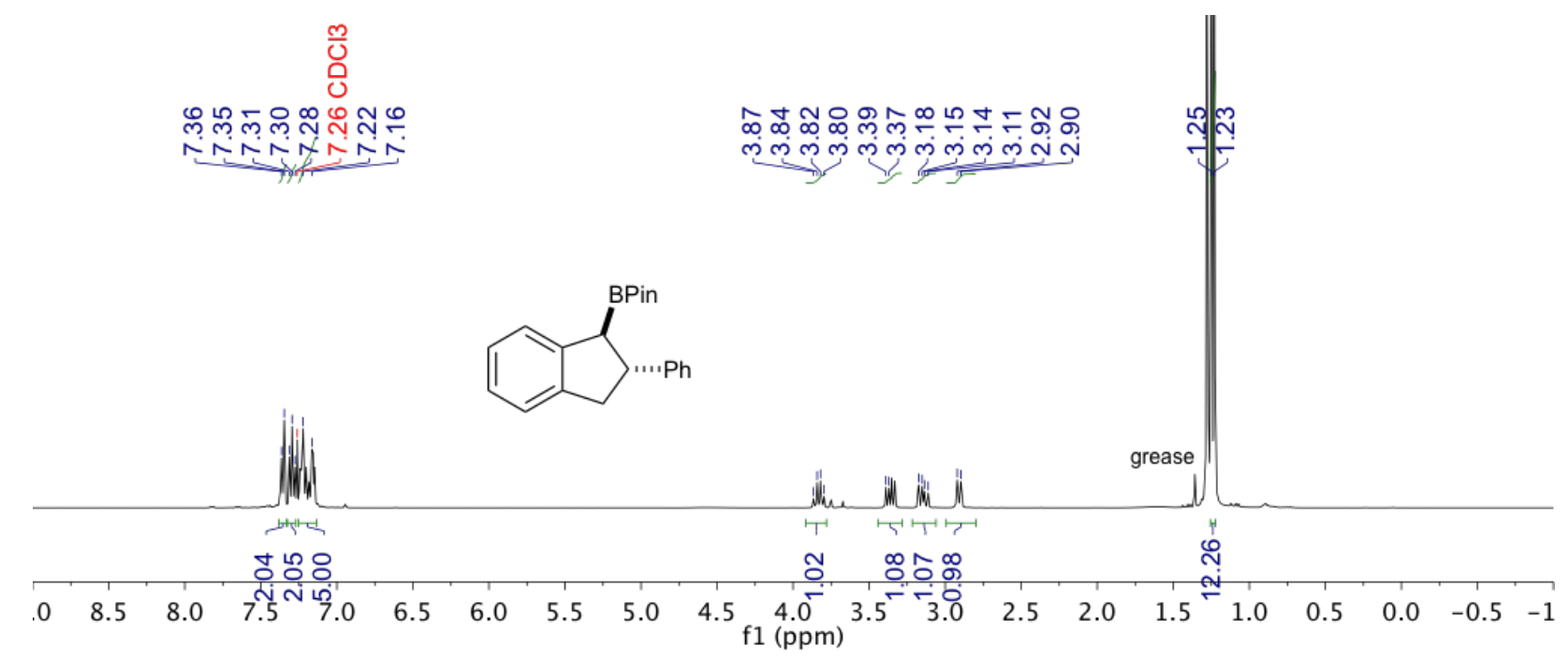

${ }^{1} \mathrm{H}$ NMR $\left(400 \mathrm{MHz}, \mathrm{CDCl}_{3}, 23^{\circ} \mathrm{C}\right)$ spectrum of $2 \mathrm{t}$.

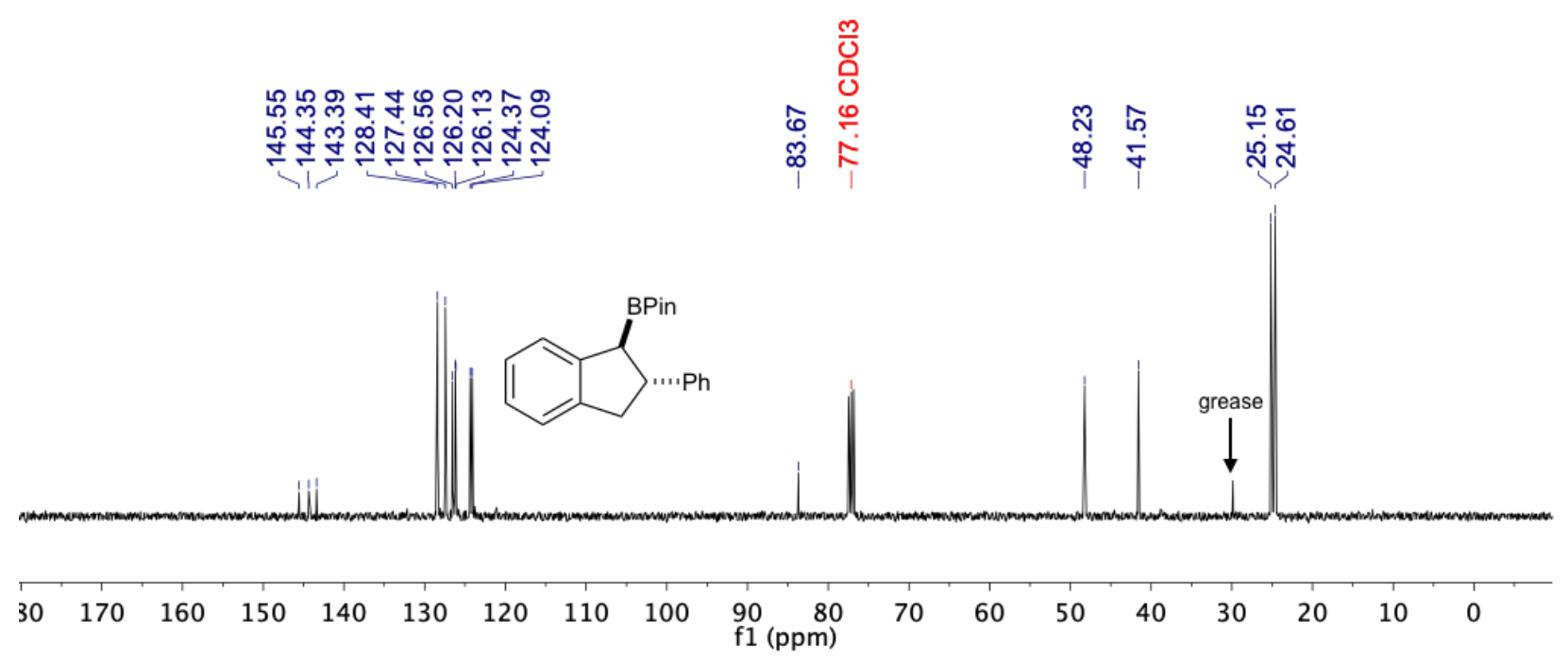

${ }^{13} \mathrm{C}$ NMR $\left(101 \mathrm{MHz}, \mathrm{CDCl}_{3}, 23^{\circ} \mathrm{C}\right)$ spectrum of $2 \mathrm{t}$ 


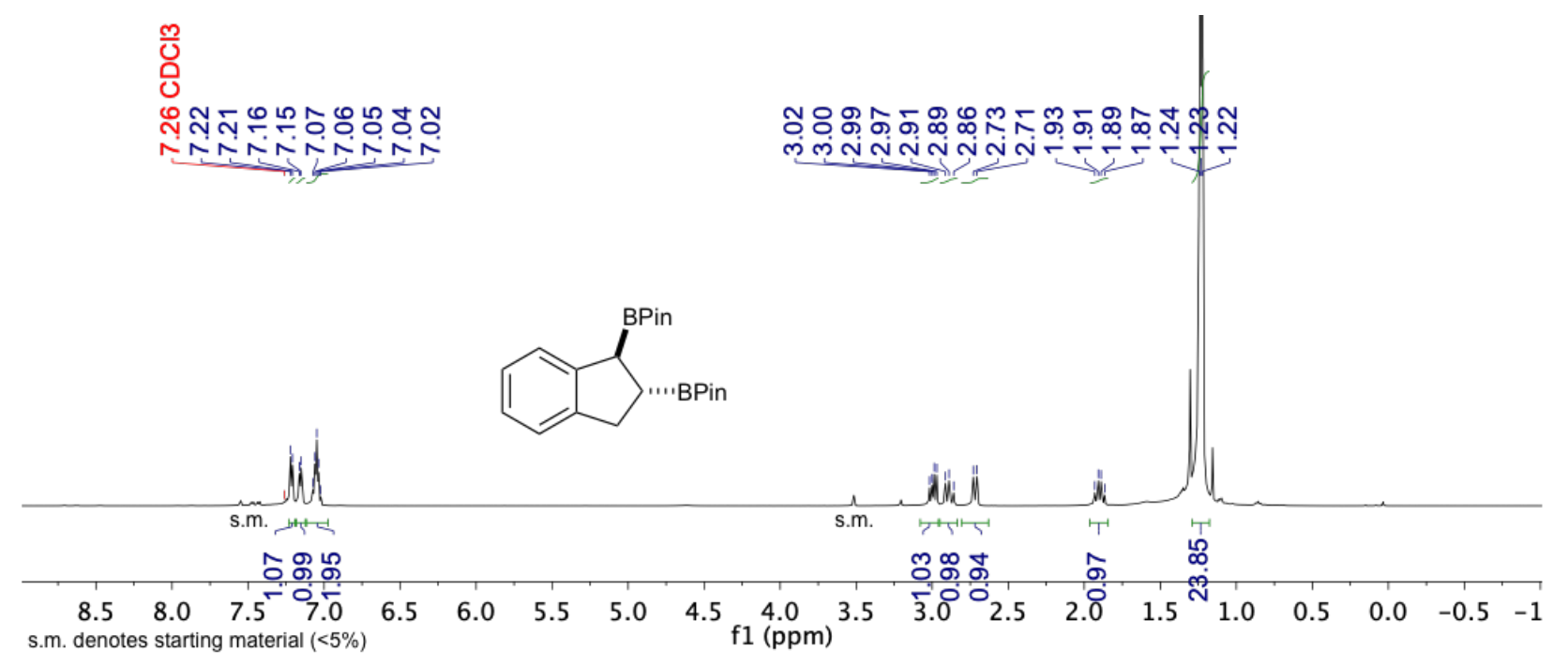

${ }^{1} \mathrm{H}$ NMR $\left(400 \mathrm{MHz}, \mathrm{CDCl}_{3}, 23^{\circ} \mathrm{C}\right)$ spectrum of $2 \mathrm{u}$.

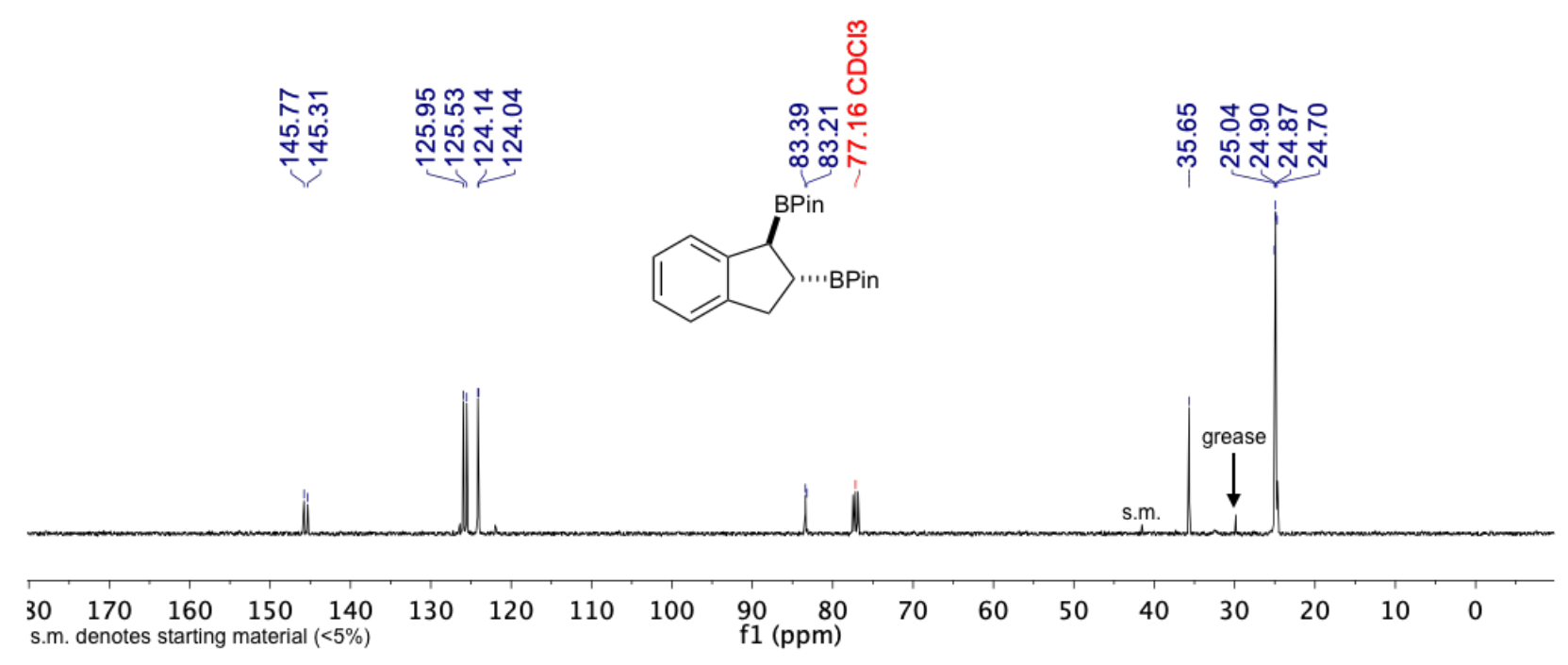

${ }^{13} \mathrm{C}$ NMR $\left(101 \mathrm{MHz}, \mathrm{CDCl}_{3}, 23^{\circ} \mathrm{C}\right)$ spectrum of $2 \mathrm{u}$. 


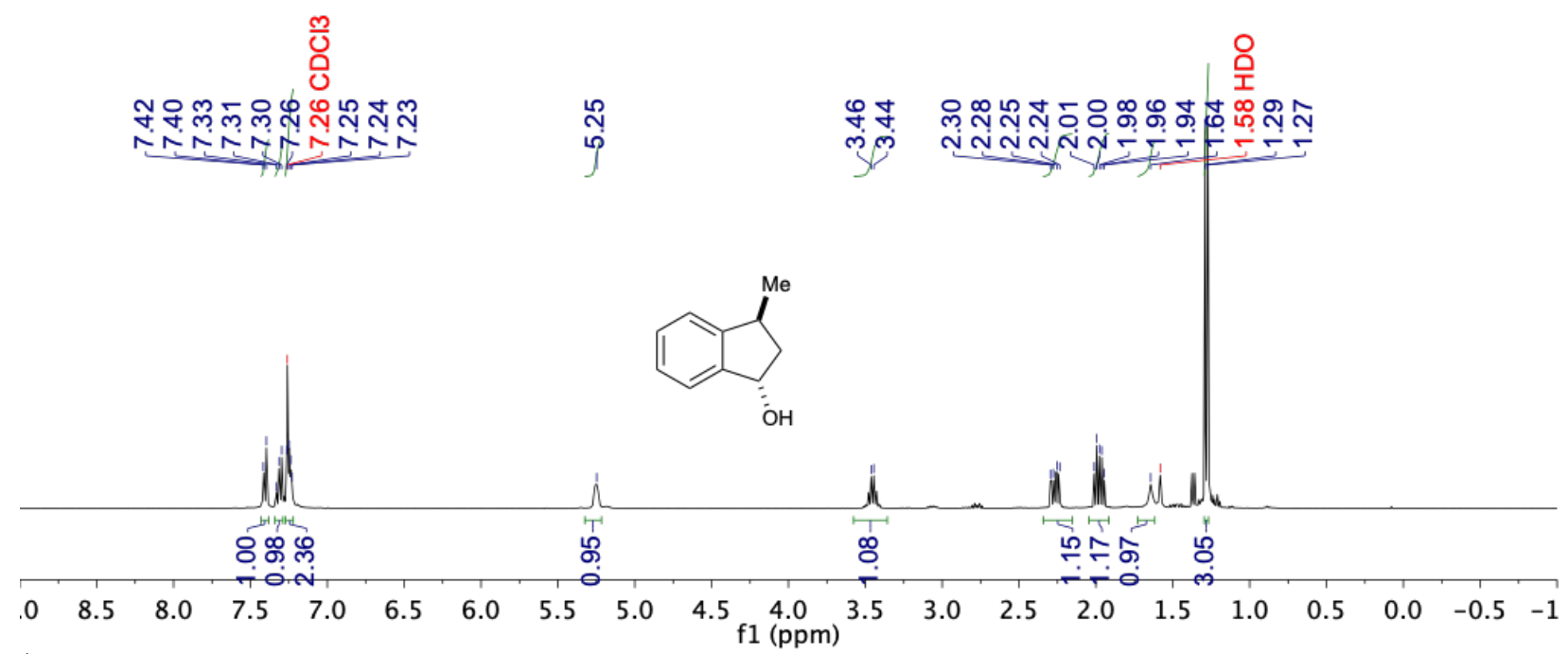

${ }^{1} \mathrm{H}$ NMR $\left(500 \mathrm{MHz}, \mathrm{CDCl}_{3}, 23^{\circ} \mathrm{C}\right)$ spectrum of $3 \mathrm{a}$.

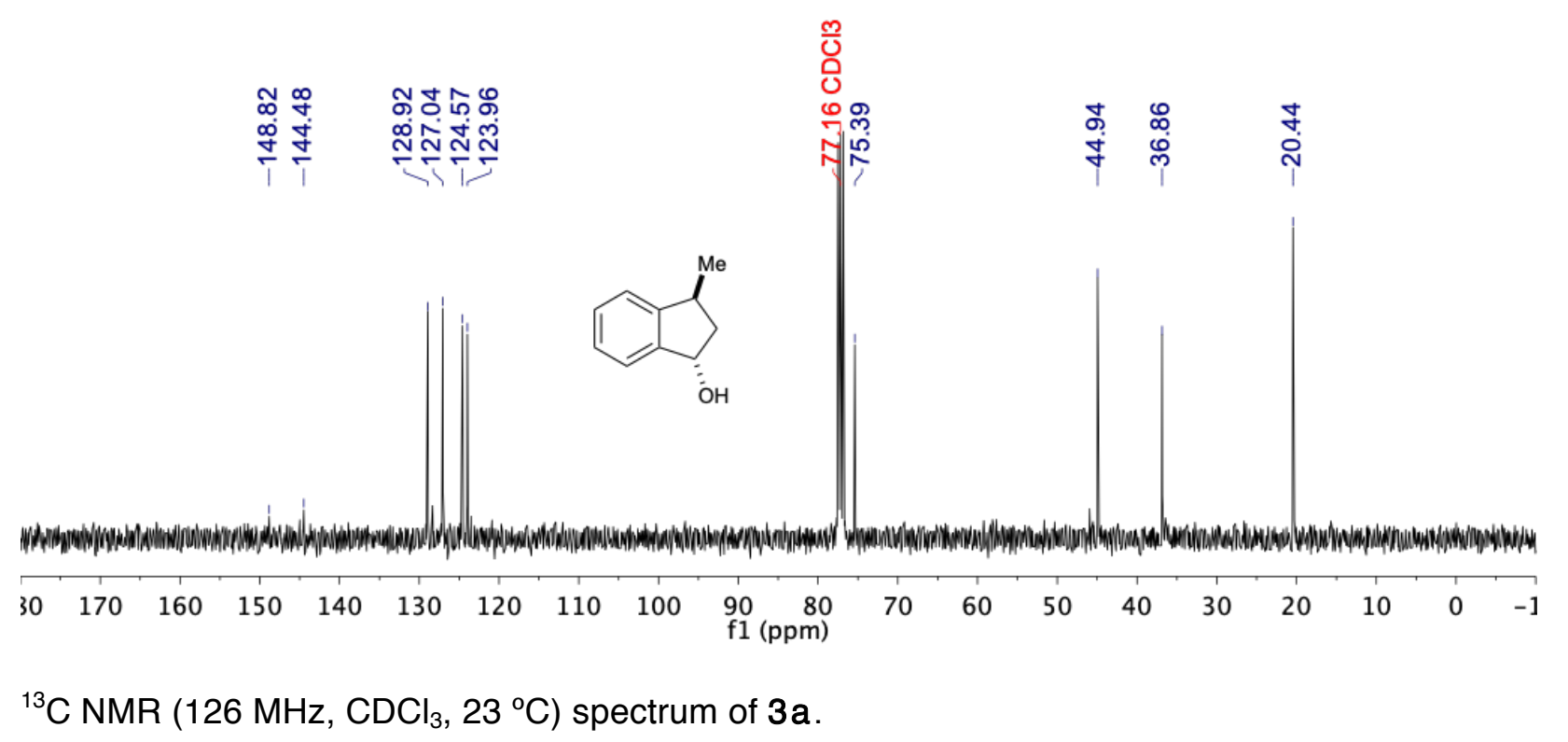




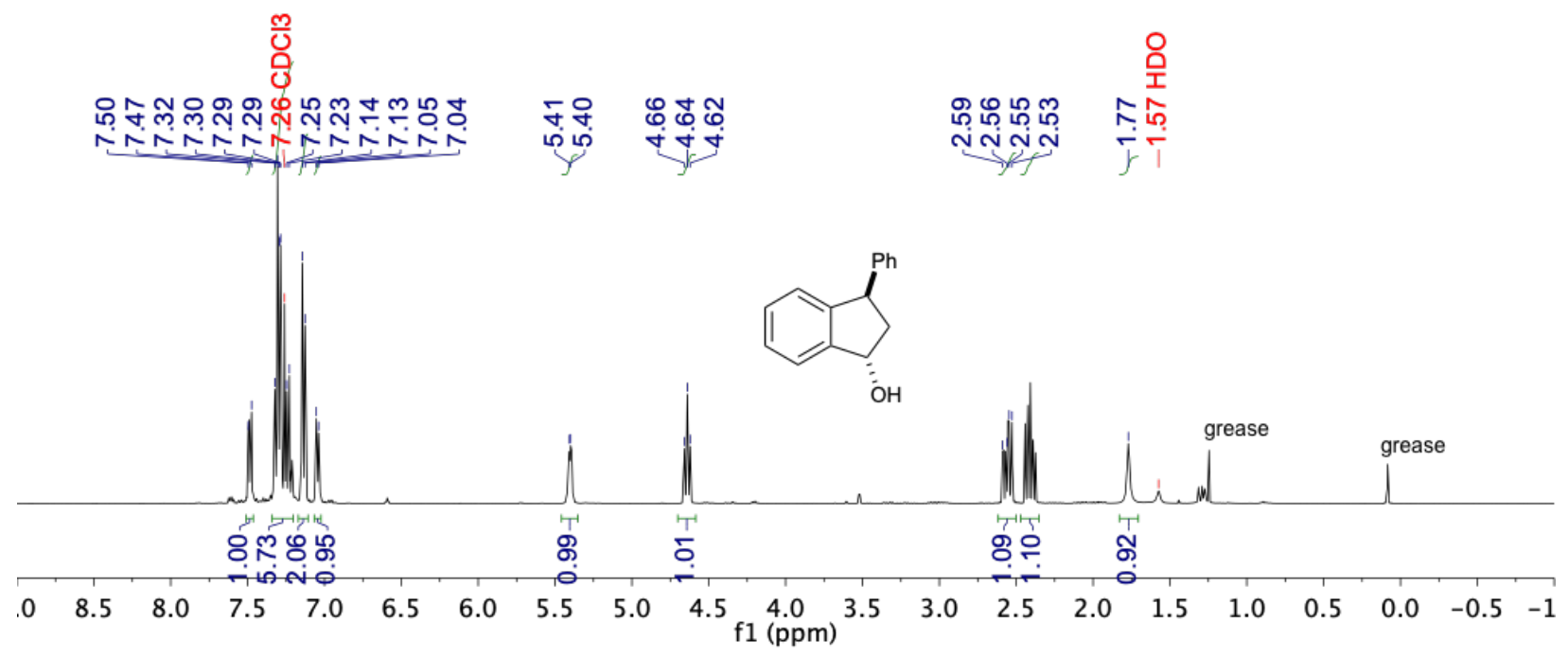

${ }^{1} \mathrm{H}$ NMR $\left(500 \mathrm{MHz}, \mathrm{CDCl}_{3}, 23^{\circ} \mathrm{C}\right)$ spectrum of $3 e$.

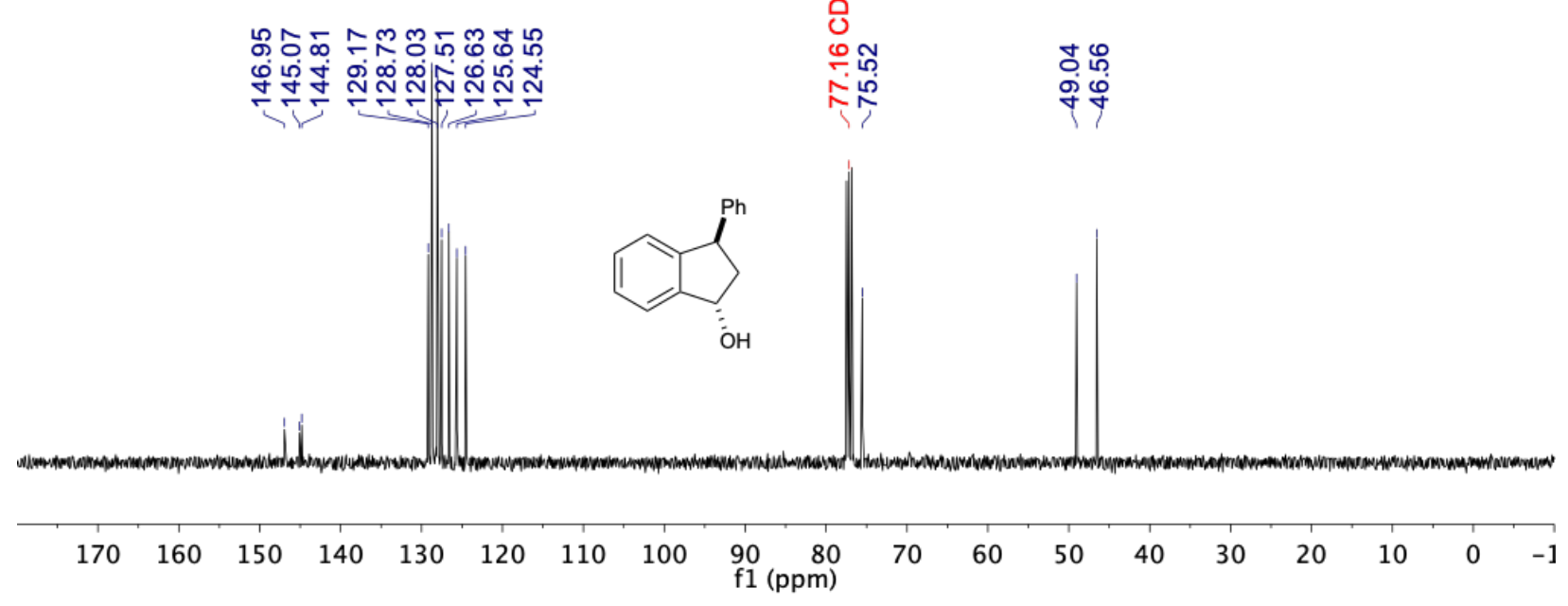

${ }^{13} \mathrm{C}$ NMR $\left(126 \mathrm{MHz}, \mathrm{CDCl}_{3}, 23^{\circ} \mathrm{C}\right)$ spectrum of $3 e$. 


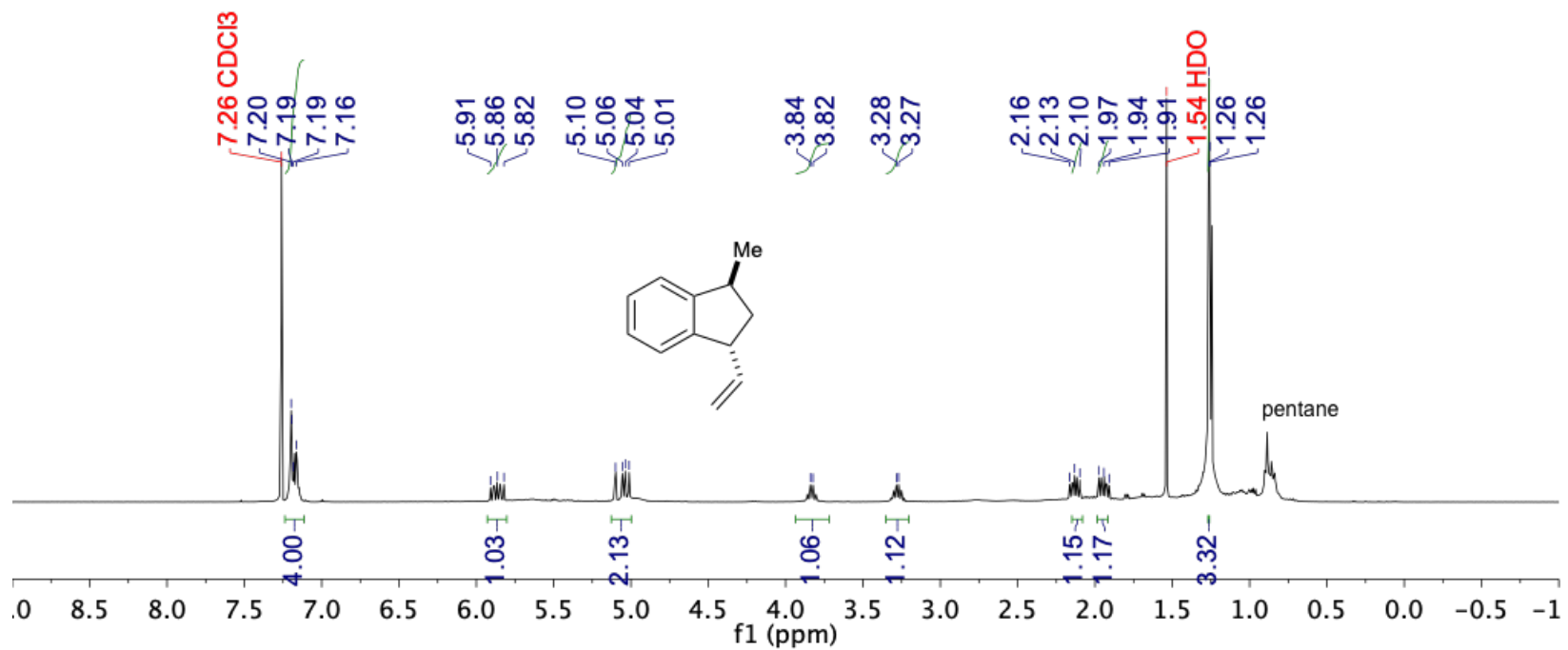

${ }^{1} \mathrm{H}$ NMR $\left(500 \mathrm{MHz}, \mathrm{CDCl}_{3}, 23^{\circ} \mathrm{C}\right)$ spectrum of $4 \mathrm{a}$.

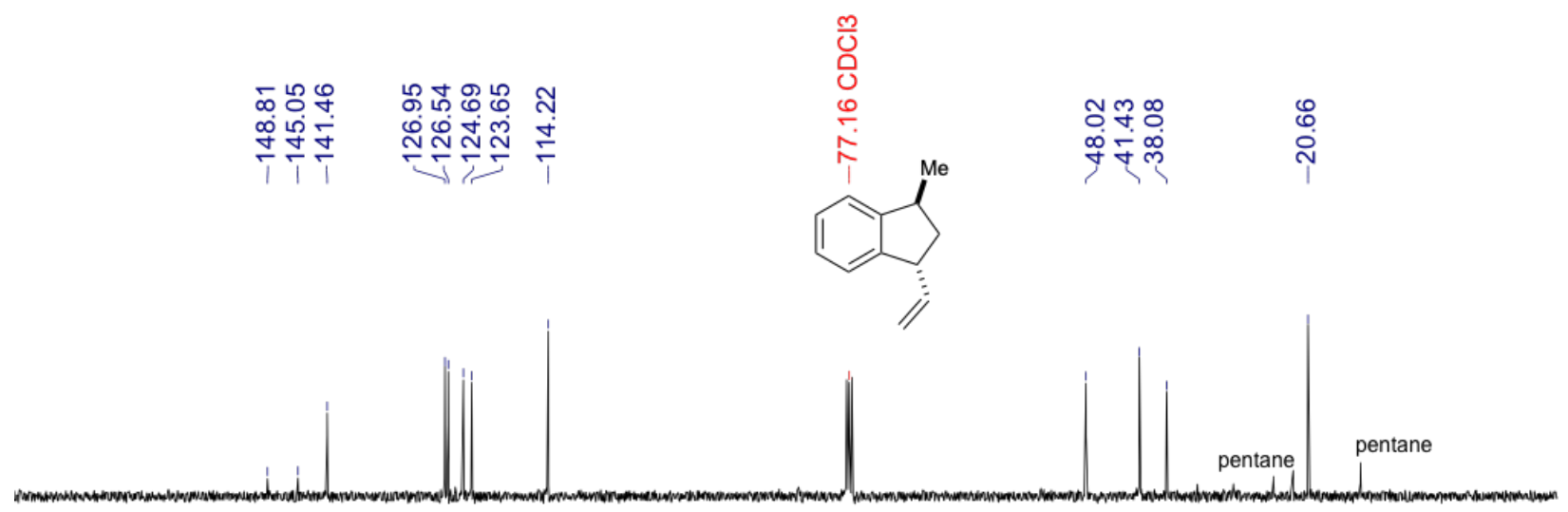

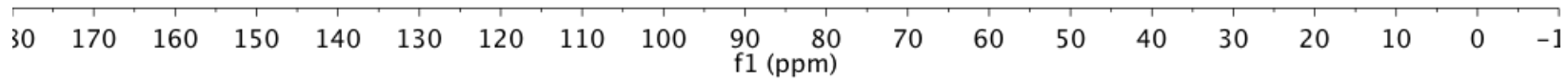

${ }^{13} \mathrm{C}$ NMR $\left(126 \mathrm{MHz}, \mathrm{CDCl}_{3}, 23^{\circ} \mathrm{C}\right)$ spectrum of $4 \mathrm{a}$. 


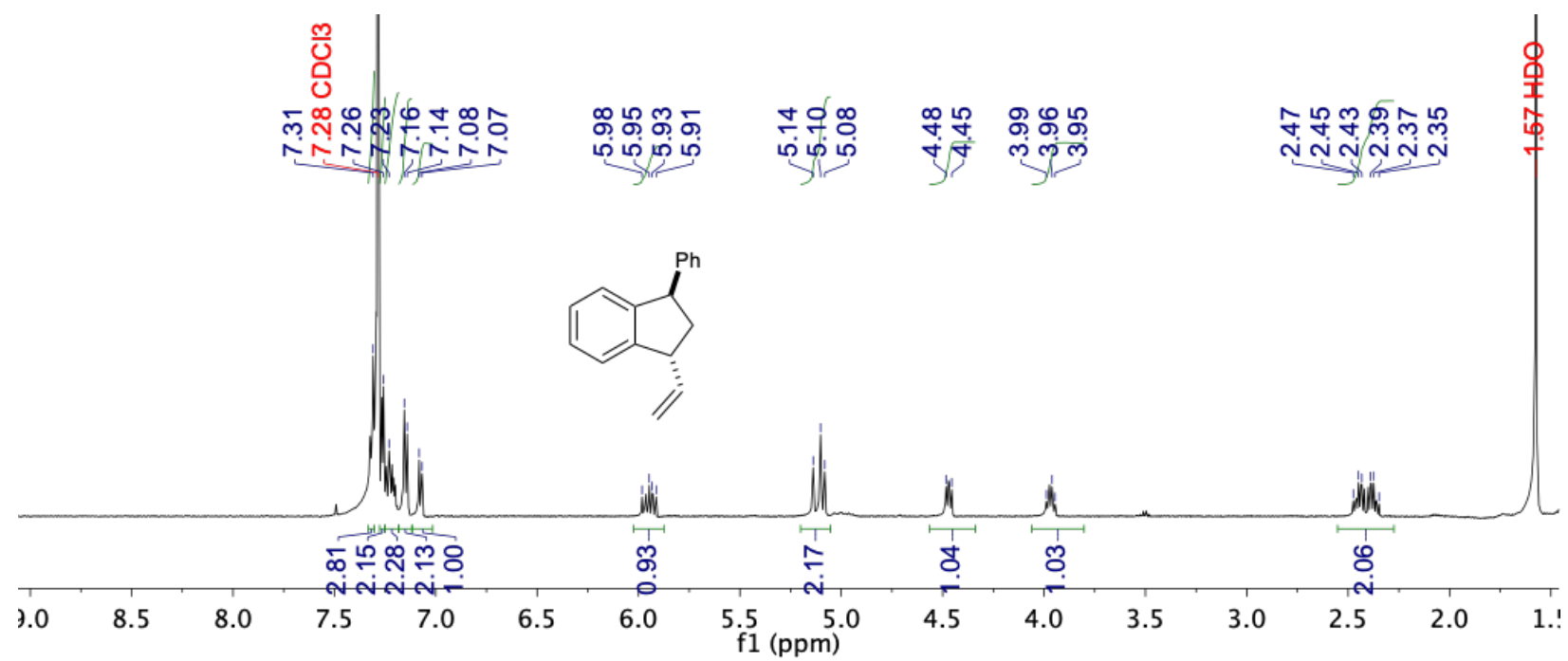

${ }^{1} \mathrm{H}$ NMR $\left(500 \mathrm{MHz}, \mathrm{CDCl}_{3}, 23^{\circ} \mathrm{C}\right)$ spectrum of $4 \mathrm{e}$.

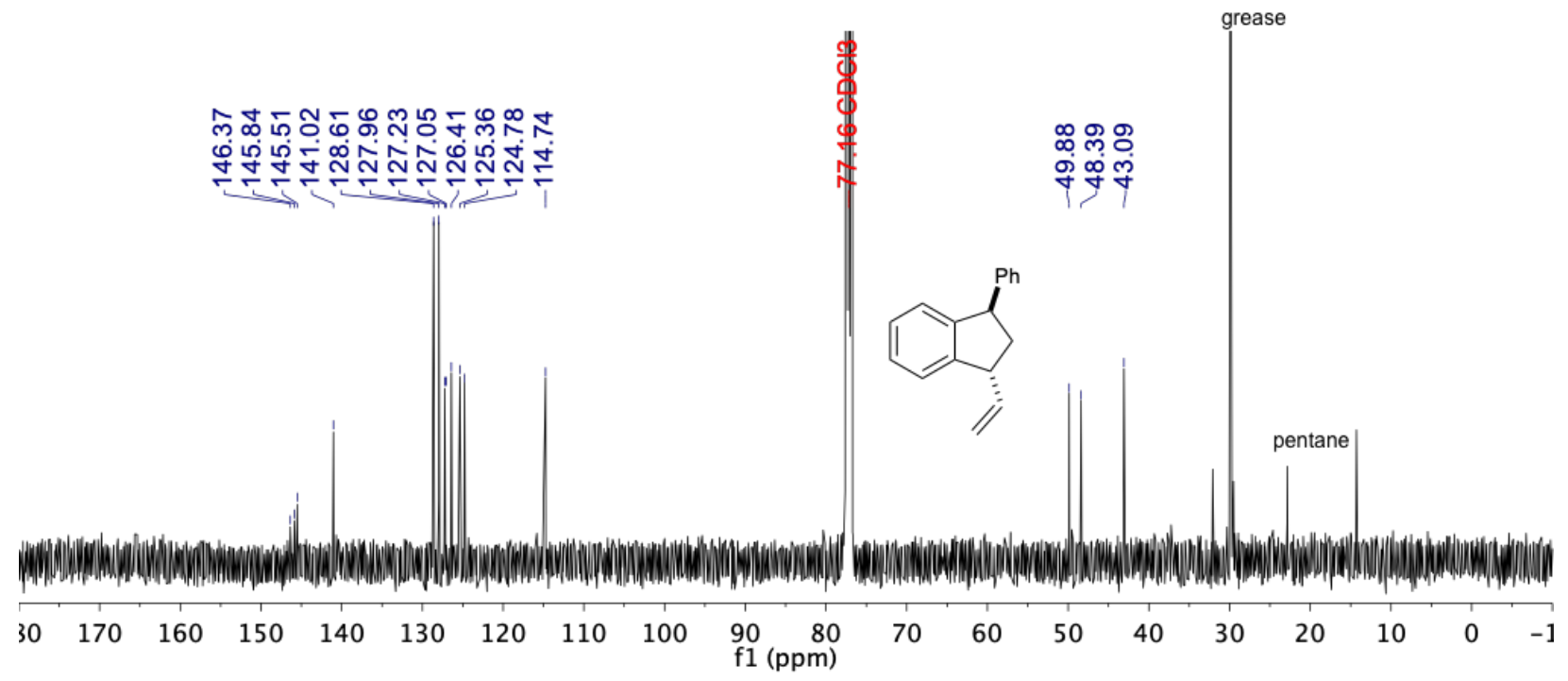

${ }^{13} \mathrm{C}$ NMR $\left(126 \mathrm{MHz}, \mathrm{CDCl}_{3}, 23^{\circ} \mathrm{C}\right)$ spectrum of $4 \mathrm{e}$. 


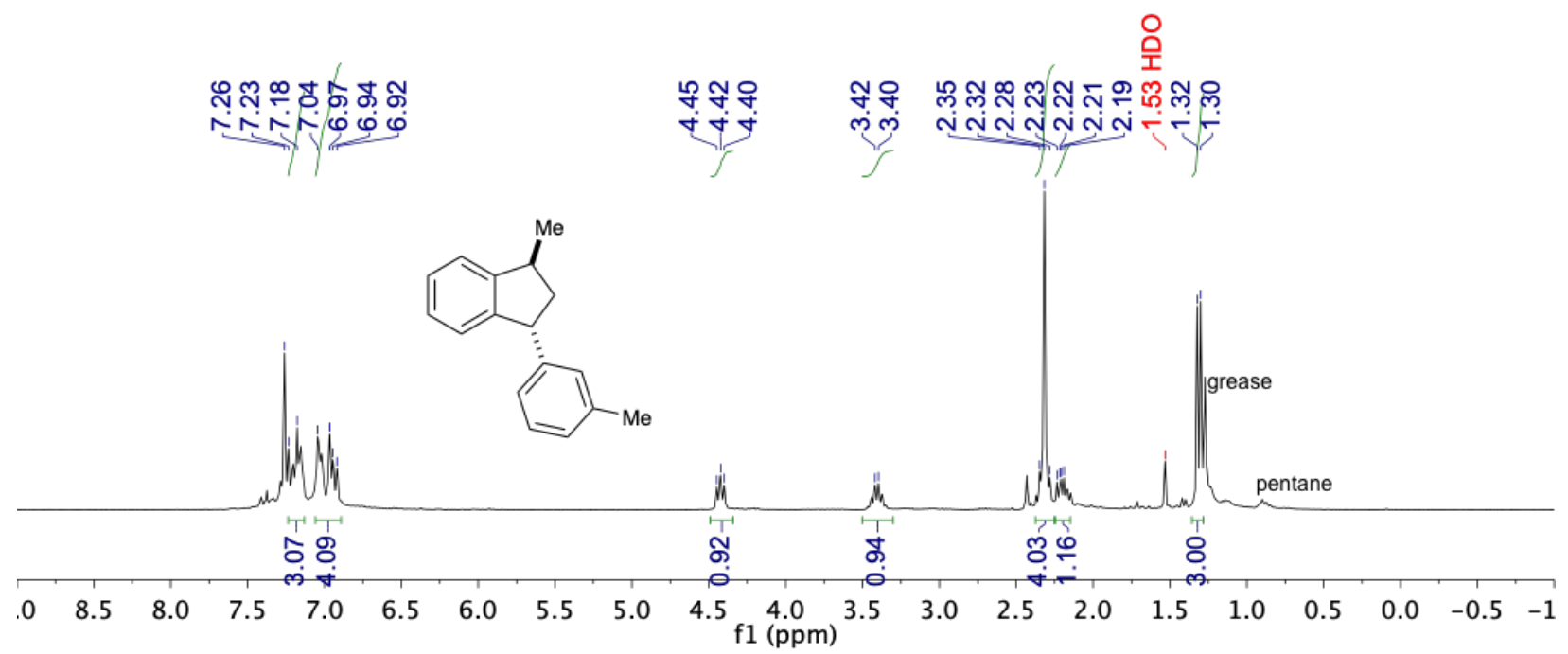

${ }^{1} \mathrm{H}$ NMR $\left(500 \mathrm{MHz}, \mathrm{CDCl}_{3}, 23^{\circ} \mathrm{C}\right)$ spectrum of $5 \mathrm{a}$.

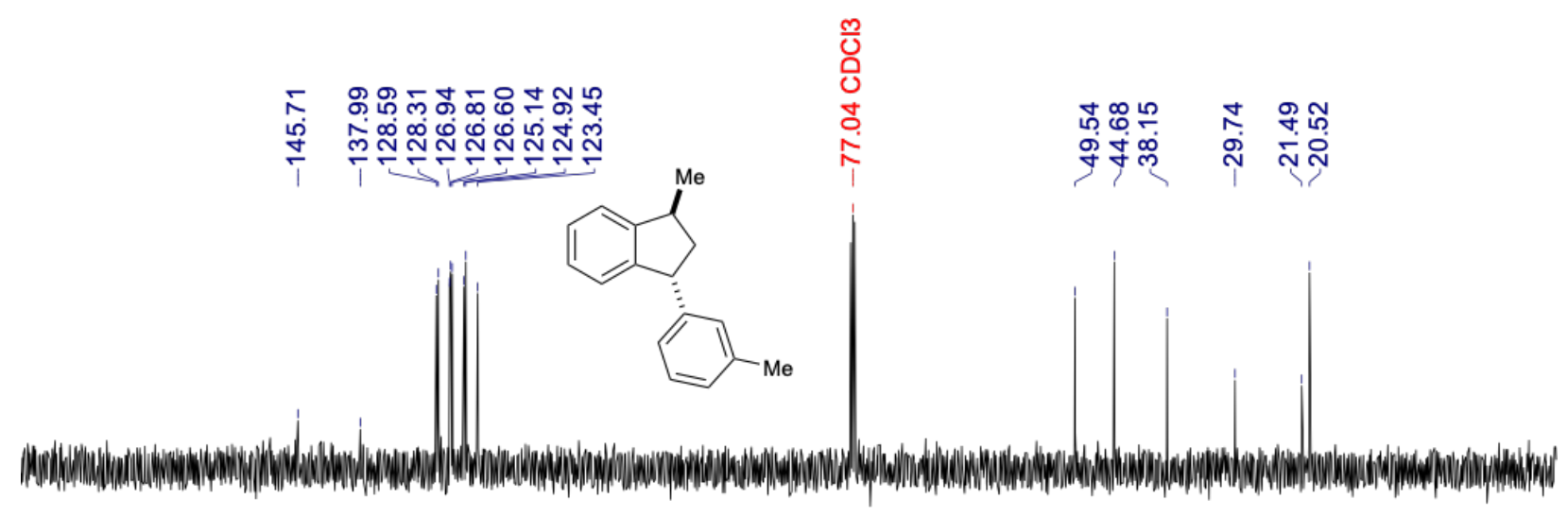

$\begin{array}{lllllllllllllllllll}30 & 170 & 160 & 150 & 140 & 130 & 120 & 110 & 100 & \begin{array}{c}90 \\ \mathrm{f} 1(\mathrm{ppm})\end{array} & 70 & 60 & 50 & 40 & 30 & 20 & 10 & 0 & -1\end{array}$

${ }^{13} \mathrm{C}$ NMR $\left(126 \mathrm{MHz}, \mathrm{CDCl}_{3}, 23^{\circ} \mathrm{C}\right)$ spectrum of $5 \mathrm{a}$. 


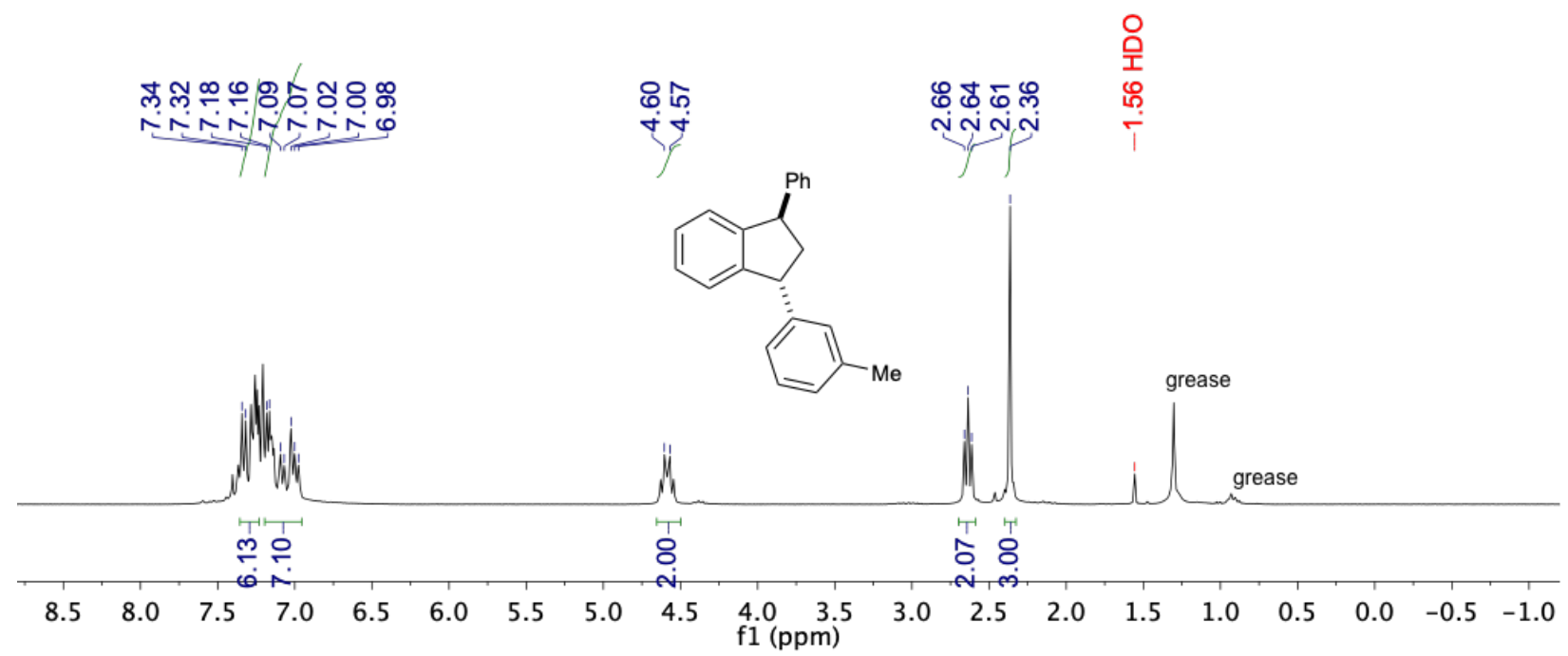

${ }^{1} \mathrm{H}$ NMR $\left(500 \mathrm{MHz}, \mathrm{CDCl}_{3}, 23^{\circ} \mathrm{C}\right)$ spectrum of $5 \mathbf{e}$.

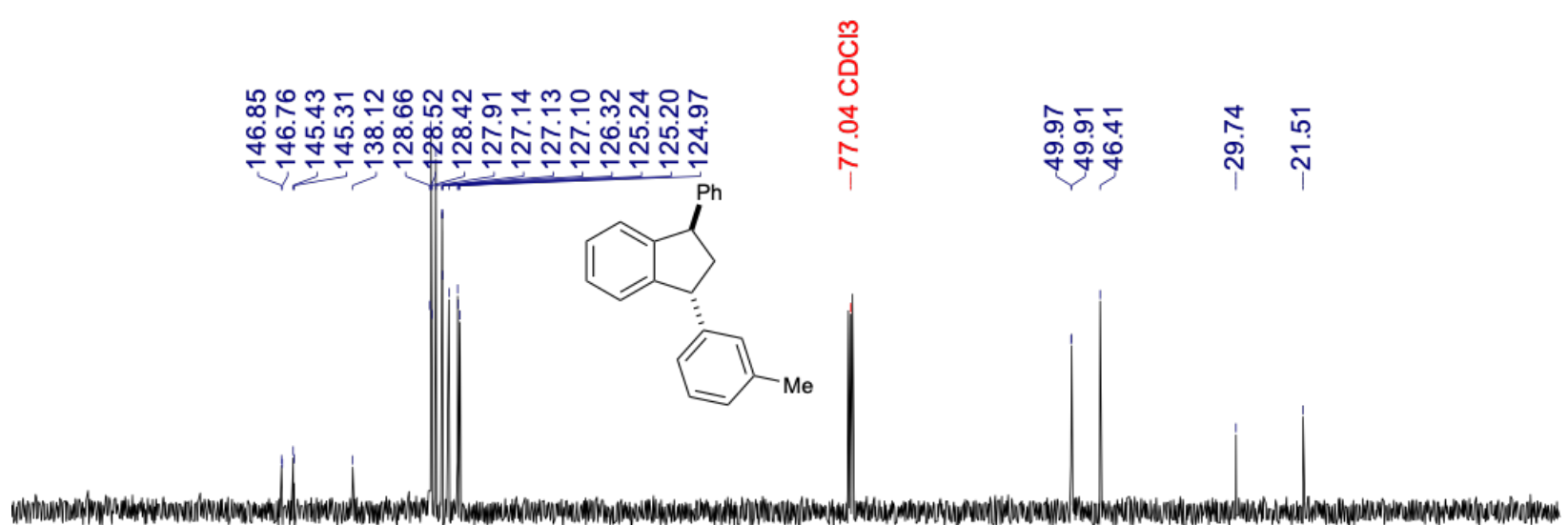

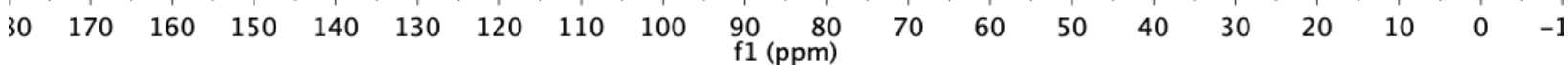

${ }^{13} \mathrm{C}$ NMR $\left(126 \mathrm{MHz}, \mathrm{CDCl}_{3}, 23^{\circ} \mathrm{C}\right)$ spectrum of $5 e$. 


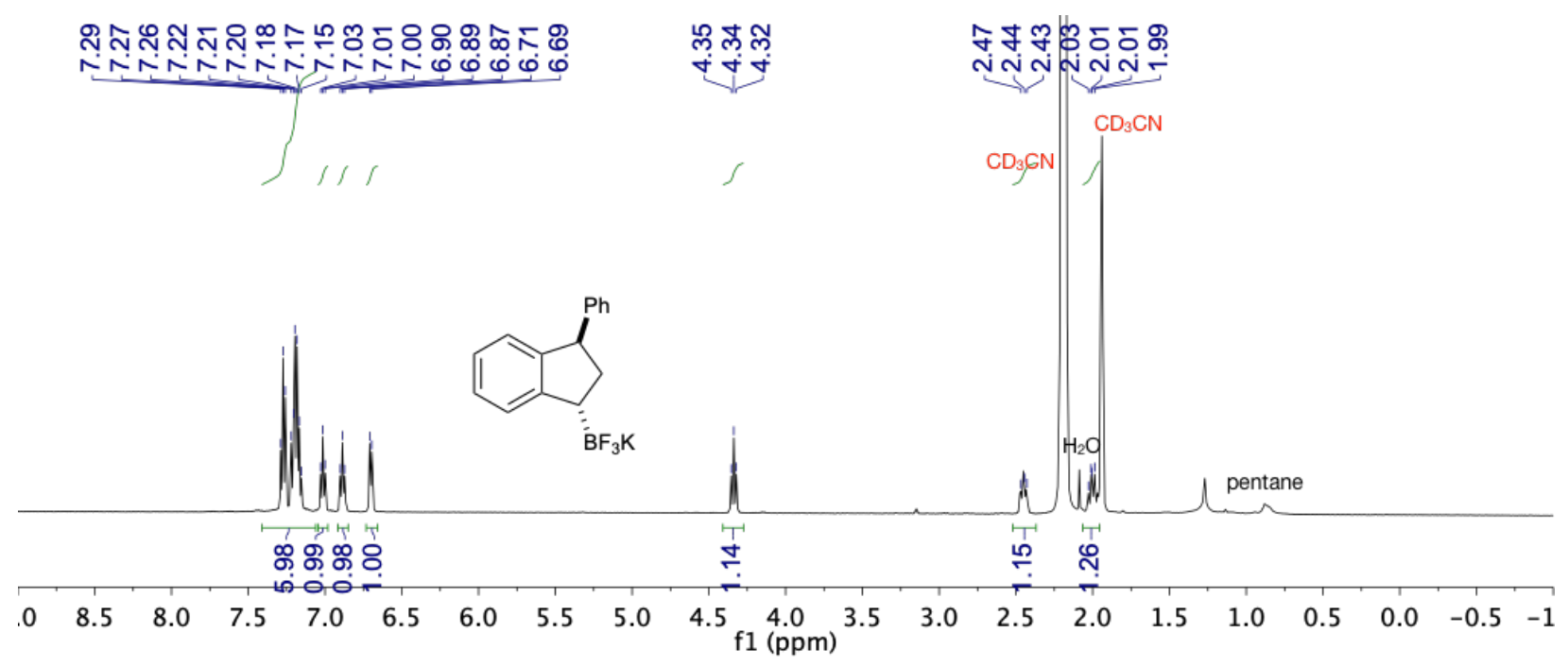

${ }^{1} \mathrm{H}$ NMR $\left(500 \mathrm{MHz}, \mathrm{CD}_{3} \mathrm{CN}, 23^{\circ} \mathrm{C}\right)$ spectrum of $6 \mathrm{e}$.

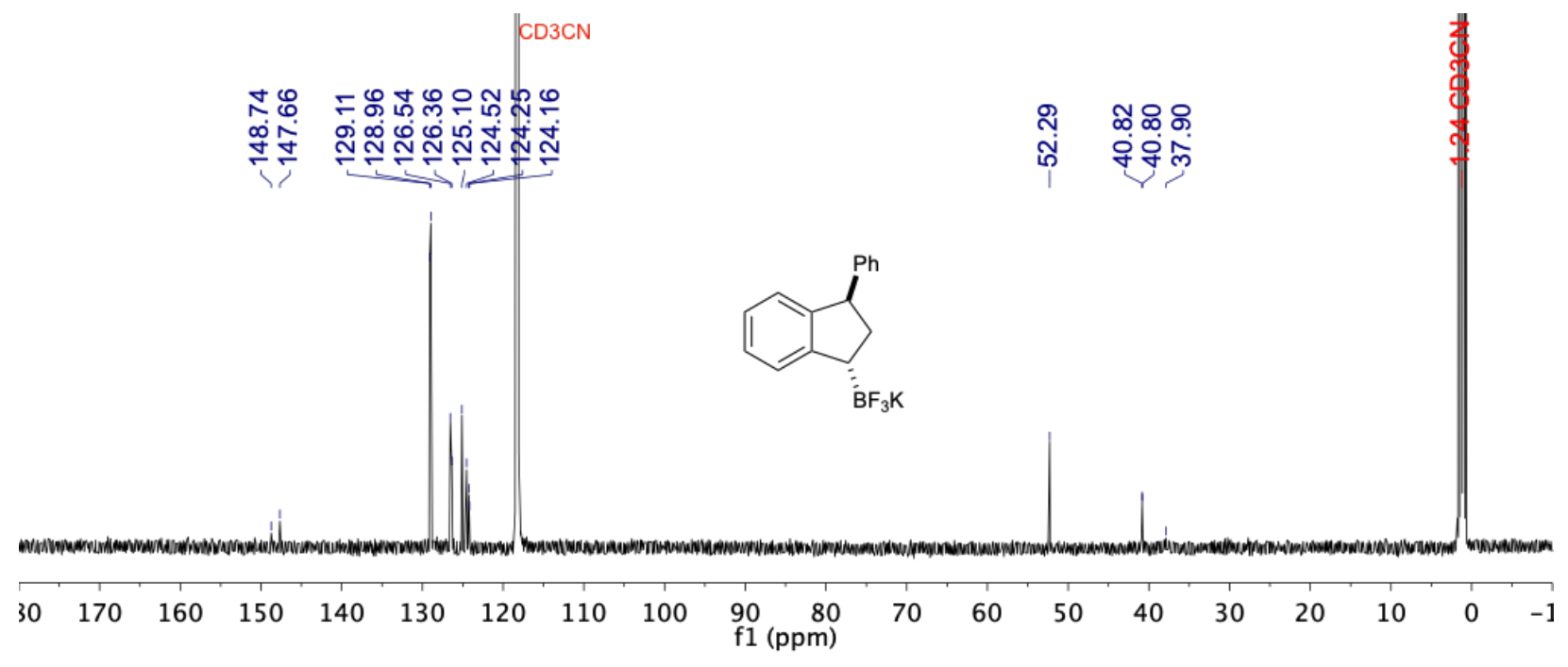

${ }^{13} \mathrm{C}$ NMR $\left(126 \mathrm{MHz}, \mathrm{CD}_{3} \mathrm{CN}, 23^{\circ} \mathrm{C}\right)$ spectrum of $6 \mathrm{e}$. 


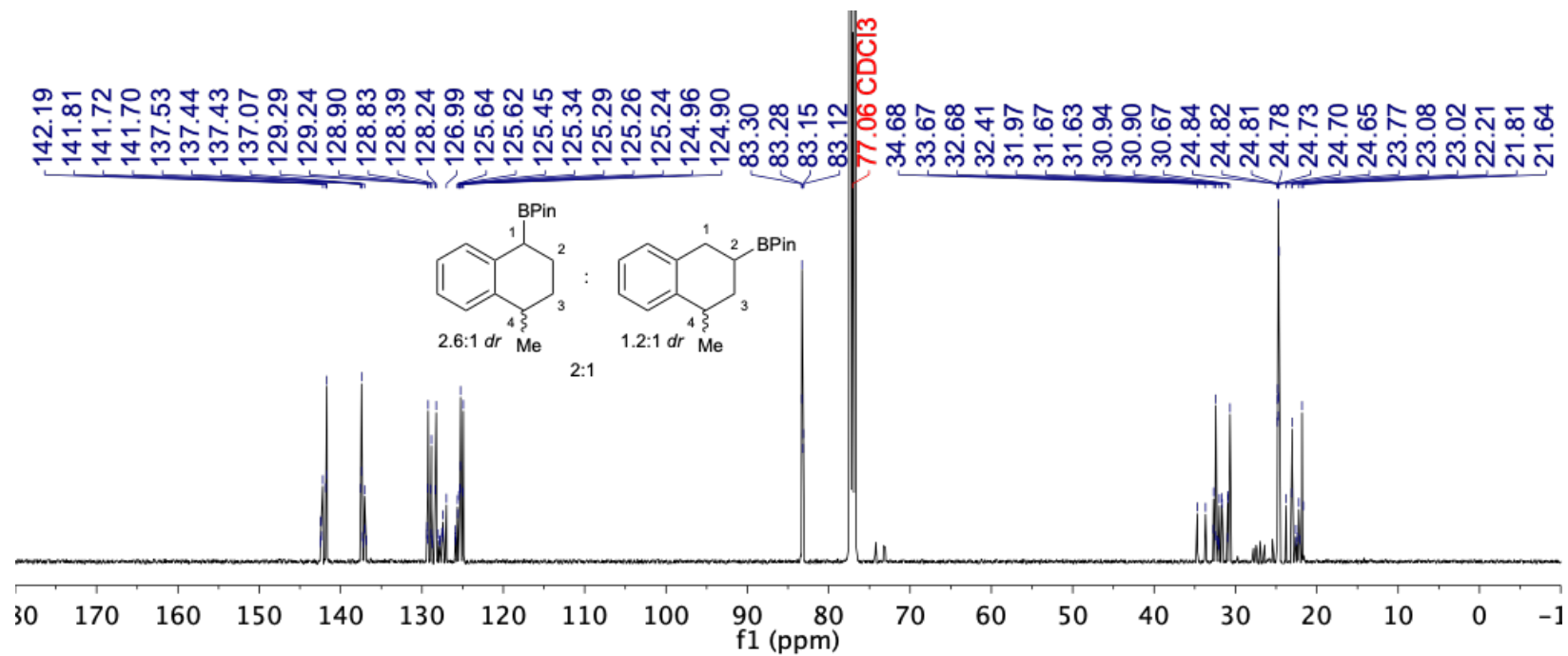

${ }^{13} \mathrm{C}$ NMR $\left(126 \mathrm{MHz}, \mathrm{CDCl}_{3}, 23^{\circ} \mathrm{C}\right)$ spectrum of $8 \mathrm{e}$.

$\frac{m}{0}$

ஸุ

NANTNO

๘

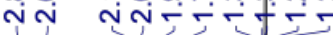
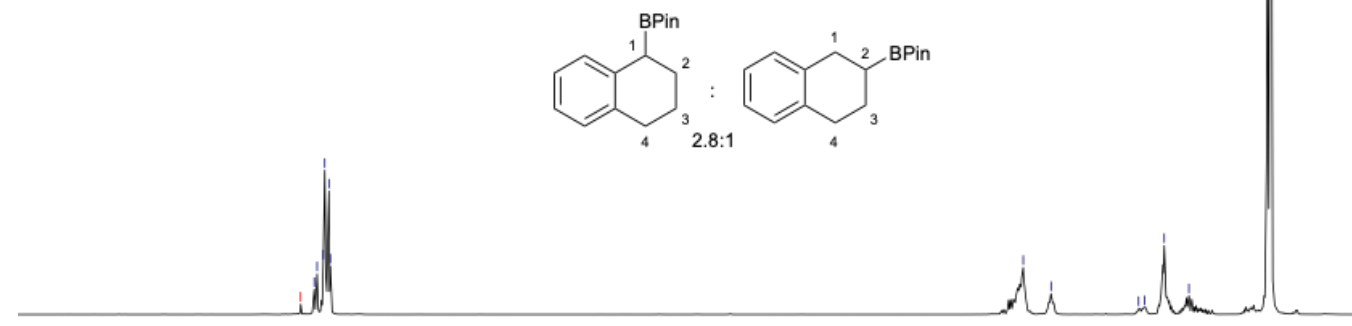

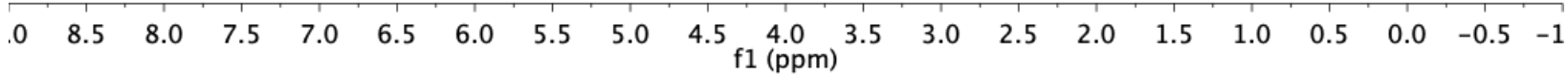

${ }^{1} \mathrm{H}$ NMR $\left(500 \mathrm{MHz}, \mathrm{CDCl}_{3}, 23^{\circ} \mathrm{C}\right)$ spectrum of $8 \mathrm{f}$. 


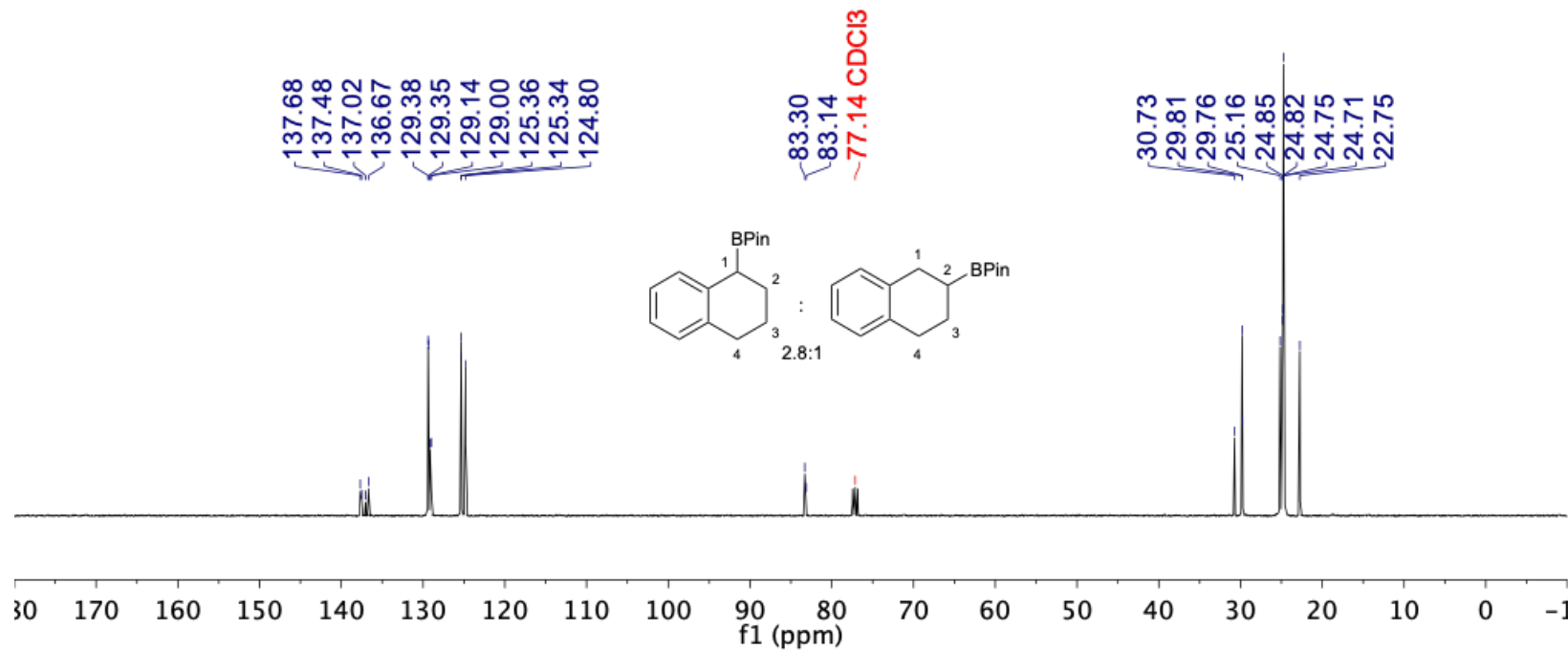

${ }^{13} \mathrm{C}$ NMR $\left(126 \mathrm{MHz}, \mathrm{CDCl}_{3}, 23^{\circ} \mathrm{C}\right)$ spectrum of $8 \mathrm{f}$.

\section{References.}

${ }^{1}$ Pangborn, A. B.; Giardello, M. A.; Grubbs, R. H.; Rosen, R. K.; Timmers, F. J. Safe and Convenient Procedure for Solvent Purification. Organometallics 1996, 15, 1518-1520.

${ }^{2}$ Krautwald, S.; Bezdek, M. J.; Chirik, P. J. Cobalt-Catalyzed 1,1-Diboration of Terminal Alkynes: Scope, Mechanism, and Synthetic Applications. J. Am. Chem. Soc. 2017, 139, 38683875.

${ }^{3}$ Léonard, N. G.; Bezdek, M. J.; Chirik, P. J. Cobalt-Catalyzed C(sp $\left.{ }^{2}\right)-H$ Borylation with an AirStable, Readily Prepared Terpyridine Cobalt(II) Bis(acetate) Precatalyst. Organometallics 2017, $36,142-150$.

${ }^{4}$ Schuster, C. H.; Diao, T.; Pappas, I.; Chirik, P. J. Bench-Stable, Substrate-Activated Cobalt Carboxylate Pre-Catalysts for Alkene Hydrosilylation with Tertiary Silanes. ACS Catal. 2016, 6, 2632-2636. 
5 Scheuermann, M. L.; Johnson, E. J.; Chirik, P. J. Alkene Isomerization-Hydroboration Promoted by Phosphine-Ligated Cobalt Catalysts. Org. Lett. 2015, 17, 2716-2719.

${ }^{6}$ Palmer, W. N.; Diao, T.; Pappas, I.; Chirik, P. J. High-Activity Cobalt Catalysts for Alkene Hydroboration with Electronically Responsive Terpyridine and $\alpha$-Diimine Ligands. ACS Catal. $2015,5,622-626$.

${ }^{7}$ Humphries, M. J.; Tellmann, K. P.; Gibson, V. C.; White, A. J. P.; Williams, D. J. Investigations into the Mechanism of Activation and Initiation of Ethylene Polymerization by Bis(imino)pyridine Cobalt Catalysts: Synthesis, Structures, and Deuterium Labeling Studies. Organometallics $2005,24,2039-2050$.

${ }^{8}$ Friedfeld, M. R.; Shevlin, M.; Margulieux, G. W.; Campeau, L-C.; Chirik, P. J. Cobalt-Catalyzed Enantioselective Hydrogenation of Minimally Functionalized Alkenes: Isotopic Labeling Provides Insight into the Origin of Stereoselectivity and Alkene Insertion Preferences. J. Am. Chem. Soc. $2016,138,3314-3324$.

${ }^{9}$ Bart, S. C.; Lobkovsky, E.; Chirik, P. J. Preparation and Molecular and Electronic Structures of Iron(0) Dinitrogen and Silane Complexes and Their Application to Catalytic Hydrogenation and Hydrosilation. J. Am. Chem. Soc. 2004, 126, 13794-13807.

10 Wrackmeyer, B. Carbon-13 NMR Spectroscopy of Boron Compounds. Prog. Nucl. Magn. Reson. Spectrosc. 1979, 12, 227-259.

${ }^{11}$ Neese, F. The ORCA program system. Wiley Interdiscip. Rev.: Comput. Mol. Sci. 2012, 2, 73-78.

${ }^{12}$ (a) Becke, A. D. Density functional calculations of molecular bond energies. J. Chem. Phys. 1986, 84, 4524-4529. (b) Becke, A. D. Density-functional thermochemistry. III. The role of exact 
exchange. J. Chem. Phys. 1993, 98, 5648-5652. (c) Lee, C. T.; Yang, W. T.; Parr, R. G. Development of the Colle-Salvetti correlation-energy formula into a functional of the electron density. Phys. Rev. B. 1998, 37, 785-789.

${ }^{13}$ (a) Schäfer, A.; Horn, H.; Ahlrichs, R. Fully optimized contracted Gaussian basis set for atoms Li to Kr. J. Chem. Phys. 1992, 97, 2571-2577. (b) Schäfer, A.; Huber, C.; Ahlrichs, R. Fully optimized contracted Gaussian basis sets of triple zeta valence quality for atoms Li to Kr. J. Chem. Phys. 1994, 100, 5829-5835. (c) Weigend, F.; Ahlrichs, R. Balanced basis sets of split valence, triple zeta valence and quadruple zeta valence quality for $\mathrm{H}$ to $\mathrm{Rn}$ : Design and assessment of accuracy. Phys. Chem. Chem. Phys. 2005, 7, 3297-3305.

${ }^{14}$ (a) Neese, F.; Wennmohs, F.; Hansen, A.; Becker, U. Efficient, Approximate and parallel Hartree-Fock and hydrid DFT calculations. A 'chain-of-spheres' algorithm for the Hatree-Fock exchange. Chem. Phys. 2009, 356, 98-109. (b) Kossmann, S.; Neese, F. Comparison of two efficient approximate Hartree-Fock approaches. Chem. Phys. Lett. 2009, 481, 240-243. (c) Neese, F. An improvement of the resolution of the identity approximation for the formation of the Coulomb matrix. J. Comput. Chem. 2003, 24, 1740-1747.

${ }^{15}$ (a) Eichkorn, K.; Weigend, F.; Treutler, O.; Ahlrichs, R. Auxiliary basis sets for main row atoms and transition metals and their use to approximate Coulomb potentials. Theor. Chem. Acc. 1997, 97, 119-124. (b) Eichkorn, K.; Treutler, O.; Öhm, H.; Häser, M.; Ahlrichs, R. Auxiliary basis sets to approximate Coulomb potentials. Chem. Phys. Lett. 1995, 240, 283-289. (c) Eichkorn, K.; Treutler, O.; Öhm, H.; Häser, M.; Ahlrichs, R. Auxiliary basis sets to approximate Coulomb potentials. Chem. Phys. Lett. 1995, 242, 652-660. 
16 Friedfeld, M. R.; Shevlin, M.; Margulieux, G. W.; Campeau, L-C.; Chirik, P. J. CobaltCatalyzed Enantioselective Hydrogenation of Minimally Functionalized Alkenes: Isotopic Labeling Provides Insight into the Origin of Stereoselectivity and Alkene Insertion Preferences. J. Am. Chem. Soc. 2016, 138, 3314-3324.

${ }^{17}$ Dichiarante, V.; Fagnoni, M.; Mella, M.; Albini, A. Intramolecular Photoarylation of Alkenes by Phenyl Cations. Chem. Eur. J. 2006, 12, 3905-3915.

${ }^{18}$ Michelet, B.; Bour, C.; Gandon, V. Gallium-Assisted Transfer Hydrogenation of Alkenes. Chem. Eur. J. 2014, 20, 14488-14492.

${ }^{19}$ Tanaka, S.; Watanabe, K.; Tanaka, Y.; Hattori, T. EtAICl$/ 2$ 2,6-Disubstituted Pyridine-Mediated Carboxylation of Alkenes with Carbon Dioxide. Org. Lett. 2016, 18, 2576-2579.

${ }^{20}$ Tenaglia, A.; Jeune, K. L.; Giordano, L.; Buono, G. Palladium-Catalyzed Addition to Alkynes to Cyclopropenes: An Entry to Stereodefined Alkynylcyclopropanes. Org. Lett. 2011, 13, 636639.

21 Zhou, Q.; Li, S.; Zhang, Y.; Wang, J. Rhodium(II)- or Copper(I)-Catalyzed Formal Intramolecular Carbene Insertion into Vinylic $\mathrm{C}\left(\mathrm{sp}^{2}\right)-\mathrm{H}$ Bonds: Access to Substituted-1HIndenes. Angew. Chem. Int. Ed. 2017, 56, 16013-16017.

${ }^{22}$ Friedfeld, M. R.; Shevlin, M.; Margulieux, G. W.; Campeau, L-C.; Chirik, P. J. CobaltCatalyzed Enantioselective Hydrogenation of Minimally Functionalized Alkenes: Isotopic Labeling Provides Insight into the Origin of Stereoselectivity and Alkene Insertion Preferences. J. Am. Chem. Soc. 2016, 138, 3314-3324. 
Saito, S.; Sato, Y.; Ohwada, T.; Shudo, K. Friedel-Crafts-Type Cyclodehydration of 1,3Diphenyl-1-propanones. Kinetic Evidence for the Involvement of Dication. J. Am. Chem. Soc. $1994,116,2312-2317$.

${ }^{24}$ Dreier, T.; Fröhlich, R.; Erker, G. Preparation and structural features of 1-(2-pyridyl)- and 1-(2furyl)indenyl-zirconium complexes. J. Organomet. Chem. 2001, 621, 197-206.

${ }^{25}$ Greifenstein, L. G.; Lambert, J. B.; Nienhuis, R. J.; Fried, H. E.; Pagani, G. A. Response of acidity and magnetic resonance properties to aryl substitution in carbon acids and derived carbanions: 2- and 3-arylindenes. J. Org. Chem. 1981, 46, 5125-5132.

${ }^{26}$ Gassman, P. G.; Ray, J. A.; Wenthold, P. G.; Mickelson, J. W. Synthesis of Perfluoroalkylated Indenes. J. Org. Chem. 1991, 56, 5143-5146.

${ }^{27}$ Davidson, A.; Rakita, P. E. Fluxional behavior of substituted indenyl derivatives of silicon and tin. J. Organomet. Chem. 1970, 23, 407-426.

28 Paquette, L. A.; Varadarajan, A.; Bay, E. Triplet-sensitized photoisomerization of 1,4disubstituted benzonorbornadienes. Intramolecular competition by electronically diverse bridgehead functionality. J. Am. Chem. Soc. 1984, 106, 6702-6708.

${ }^{29}$ Lovinger, G. J.; Aparece, M. D.; Morken, J. P. Pd-Catalyzed Conjunctive Cross-Coupling between Grignard-Derived Boron "Ate" Complexes and $\mathrm{C}\left(\mathrm{sp}^{2}\right)$ Halides or Triflates: NaOTf as a Grignard Activator and Halide Scavenger. J. Am. Chem. Soc. 2017, 139, 3153-3160.

30 Matthew, S. C.; Glasspoole, B. W.; Eisenberger, P.; Crudden, C. M. Synthesis of Enantiomerically Enriched Triarylmethanes by Enantiospecific Suzuki-Miyaura Cross-Coupling Reactions. J. Am. Chem. Soc. 2014, 136, 5828-5831. 
${ }^{31}$ Gillis, E. P.; Burke, M. D. Multistep Synthesis of Complex Boronate Acids from Simple MIDA Boronates J. Am. Chem. Soc. 2008, 130, 14084-14085.

${ }^{32}$ Noguchi, H.; Hojo, K.; Suginome, M. Boron-Masking Strategy for the Selective Synthesis of Oligoarenes via Iterative Suzuki-Miyaura Coupling J. Am. Chem. Soc. 2007, 129, 758-759.

${ }^{33}$ Adamczyk, M.; Watt, D. S.; Netzel, D. A. Synthesis of Biological Markers in Fossil Fuels. 2. Synthesis and Carbon-13 NMR Studies of Substituted Indans and Tetralins. J. Org. Chem. $1984,49,4226-4237$.

${ }^{34}$ Zhou, Q.; Li, S.; Zhang, Y.; Wang, J. Rhodium(II)- or Copper(I)-Catalyzed Formal Intramolecular Carbene Insertion into Vinylic $\mathrm{C}\left(\mathrm{sp}^{2}\right)-\mathrm{H}$ Bonds: Access to Substituted $1 \mathrm{H}$ Indenes. Angew. Chem. Int. Ed. 2017, 56, 16013-16017.

${ }^{35}$ Mkhalid, I. A. I.; Coapes, R. B.; Edes, S. N.; Coventry, D. N.; Souza, F. E. S.; Thomas, R. L.; Hall, J. J; Bi, S.-W.; Lin, Z.; Marder, T. B. Rhodium Catalyzed Dehydrogenative Borylation of Alkenes: Vinylboronates via C-H Activation. Dalton Trans. 2008, 0, 1055-1064.

${ }^{36}$ Monfette, S.; Turner, Z. R.; Semproni, S. P.; Chirik, P. J. Enantiopure $C_{1}$-Symmetric Bis(imino)pyridine Cobalt Complexes for Asymmetric Alkene Hydrogenation. J. Am. Chem. Soc. $2012,134,4561-4564$.

${ }^{37}$ Durandetti, M.; Hardou, L.; Lhermet, R.; Rouen, M.; Maddaluno, J. Synthetic Applications of the Nickel-Catalyzed Cyclization of Alkynes Combined with Addition Reactions in a Domino Process. Chem. Eur. J. 2011, 17, 12773-12783.

${ }^{38}$ Villaseñor, E.; Gutierrez-Gonzalez, R.; Carrillo-Hermosilla, F.; Fernández-Galán, R.; López-Solera, I.; Fernández-Pacheco, A. R.; Antiñolo, A. Neutral Dimethylzirconocene Complexes as Initiators for the Ring-Opening Polymerization of $\varepsilon$-Caprolactone. Eur. J. Inorg. Chem. 2013, 2013, 1184-1196. 
${ }^{39}$ Soicke, A.; Slavov, N.; Neudörfl, J.-M.; Schmalz, H.-G. Metal-Free Intramolecular CarbonylOlefin Metathesis of ortho-Prenylaryl Ketones. Synlett 2011, 17, 2487-2490.

${ }^{40}$ Xu, L.; Li, B.-J.; Wu, Z.-H.; Lu, X.-Y.; Guan, B.-T.; Wang, B.-Q.; Zhao, K.-Q.; Shi, Z.-J. NickelCatalyzed Efficient and Practical Suzuki-Miyaura Coupling of Alkenyl and Aryl Carbamates with Aryl Boroxines. Org. Lett. 2010, 12, 884-887.

${ }^{41}$ Adam, G.; Andrieux, J.; Plat, M. Nouvelle method de synthese de tetrahydro-2,3,4,5 benzo(b) 1H-azepines substituees en position-2. Tetrahedron 1982, 38, 2403-2410.

${ }^{42}$ Purohit, V. C.; Allwein, S. P.; Bakale, R. P. Catalytic Oxidative 1,2-Shift in 1,1'-Disubstituted Olefins Using Arene(iodo)sulfnic Acid as the Precatalyst and Oxone as the Oxidant. Org. Lett. 2013, 15, 1650-1653.

${ }^{43}$ Davies, H. M. L.; Waliji, A. M. Direct Synthesis of (+)-Erogorgiaene through a Kinetic Enantiodifferentiating Step. Angew. Chem. Int. Ed. 2005, 44, 1733-1735.

${ }^{44}$ Zhao, Y.; Weix, D. J. Nickel-Catalyzed Regiodivergent Opening of Epoxides with Aryl Halides" Co-Catalysis Controls Regioselectivity. J. Am. Chem. Soc. 2014, 136, 48-51.

45 Boudier, A.; Darcel, C.; Flachsmann, F.; Micouin, L.; Oestreich, M.; Knochel, P. Stereoselective Preparations and Reactions of Configurationally Defined Dialkylzinc Compounds. Chem. Eur. J. 2000, 6, 2748-2761.

${ }^{46}$ Wang, S.; Huang, H.; Tsareva, S.; Bruneau, C.; Fischmeister, C. Silver-Catalyzed Hydrogenation of Ketones under Mild Conditions. Adv. Synth. Catal. 2019, 361, 786-790.

${ }^{47} \mathrm{Wu}, \mathrm{J}$. Y.; Moreau, B.; Ritter, T. Iron-Catalyzed 1,4-Hydroboration of 1,3-Dienes J. Am. Chem.

Soc. $2009,131,12915-12927$. 
${ }^{48}$ Clerici, A.; Pastori, N.; Porta, O. Reduction of Aliphatic and Aromatic Cyclic Ketones to secAlcohols by Aqueous Titanium Trichloride/Ammonia System. Steric Course and Mechanistic Implications. Eur. J. Org. Chem. 2001, 2235-2243.

${ }^{49}$ Sonawane, R. P.; Jheengut, V.; Rabalakos, C.; Larouche-Gauthier, R.; Scott, H. K.; Aggarwal, V. K. Enantioselective Construction of Quaternary Stereogenic Centers from Tertiary Boronic Esters: Methodology and Applications Angew. Chem. Int. Ed. 2011, 50, 3760-3763.

${ }^{50}$ Imao, D.; Glasspoole, B. W.; Laberge, V. S.; Crudden, C. M. Cross Coupling Reactions of Chiral Secondary Organoboronic Esters With Retention of Configuration. J. Am. Chem. Soc. $2009,131,5024-5025$.

${ }^{51}$ Bagutski, V.; Ros, A.; Aggarwal, V. K. Improved method for the conversion of pinacolboronic esters into trifluoroborate salts: facile synthesis of chiral secondary and tertiary trifluoroborates. Tetrahedron 2009, 65, 9956-9960.

${ }^{52}$ Burés, J. A Simple Graphical Method to Determine the Order in Catalyst. Angew. Chem. Int. Ed. 2016, 55, 2028-2031.

${ }^{53}$ Burés, J. Variable Time Normalization Analysis: General Graphical Elucidation of Reaction Orders From Concentration Profiles. Angew. Chem. Int. Ed. 2016, 55, 16084-16087.

${ }^{54}$ Obligacion, J. V.; Chirik, P. J. Bis(imino)pyridine Cobalt-Catalyzed Alkene IsomerizationHydroboration: A Strategy for Remote Hydrofunctionalization with Terminal Selectivity. J. Am. Chem. Soc. 2013, 135, 19107-19110.

55 Li, H.; Wang, L.; Zhang, Y.; Wang, J. Transition-Metal-Free Synthesis of Pinacol Alkyboronates from Tosylhydrazones. Angew. Chem. Int. Ed. 2012, 51, 2943-2946. 
56 Liu, Y.; Zhou, Y.; Wang, H.; Qu, J. $\mathrm{FeCl}_{2}$-catalyzed hydroboration of aryl alkenes with bis(pinacolato)diboron. $R S C$ Adv. 2015, 5, 73705-73713. 